Portland State University

PDXScholar

$11-2019$

\title{
The Link between Transit Station Proximity and Real Estate Rents, Jobs, People and Housing with Transit and Land Use Planning Implications
}

Arthur C. Nelson

University of Arizona

Robert Hibberd

University of Arizona

Follow this and additional works at: https://pdxscholar.library.pdx.edu/trec_reports

Part of the Transportation Commons, Urban Studies Commons, and the Urban Studies and Planning Commons

Let us know how access to this document benefits you.

\section{Recommended Citation}

Nelson, Arthur C. and Robert Hibberd. The Link between Transit Station Proximity and Real Estate Rents, Jobs, People and Housing with Transit and Land Use Planning Implications. NITC-RR-1103. Portland, OR: Transportation Research and Education Center (TREC), 2019. https://doi.org/10.15760/trec.235

This Report is brought to you for free and open access. It has been accepted for inclusion in TREC Final Reports by an authorized administrator of PDXScholar. Please contact us if we can make this document more accessible: pdxscholar@pdx.edu. 


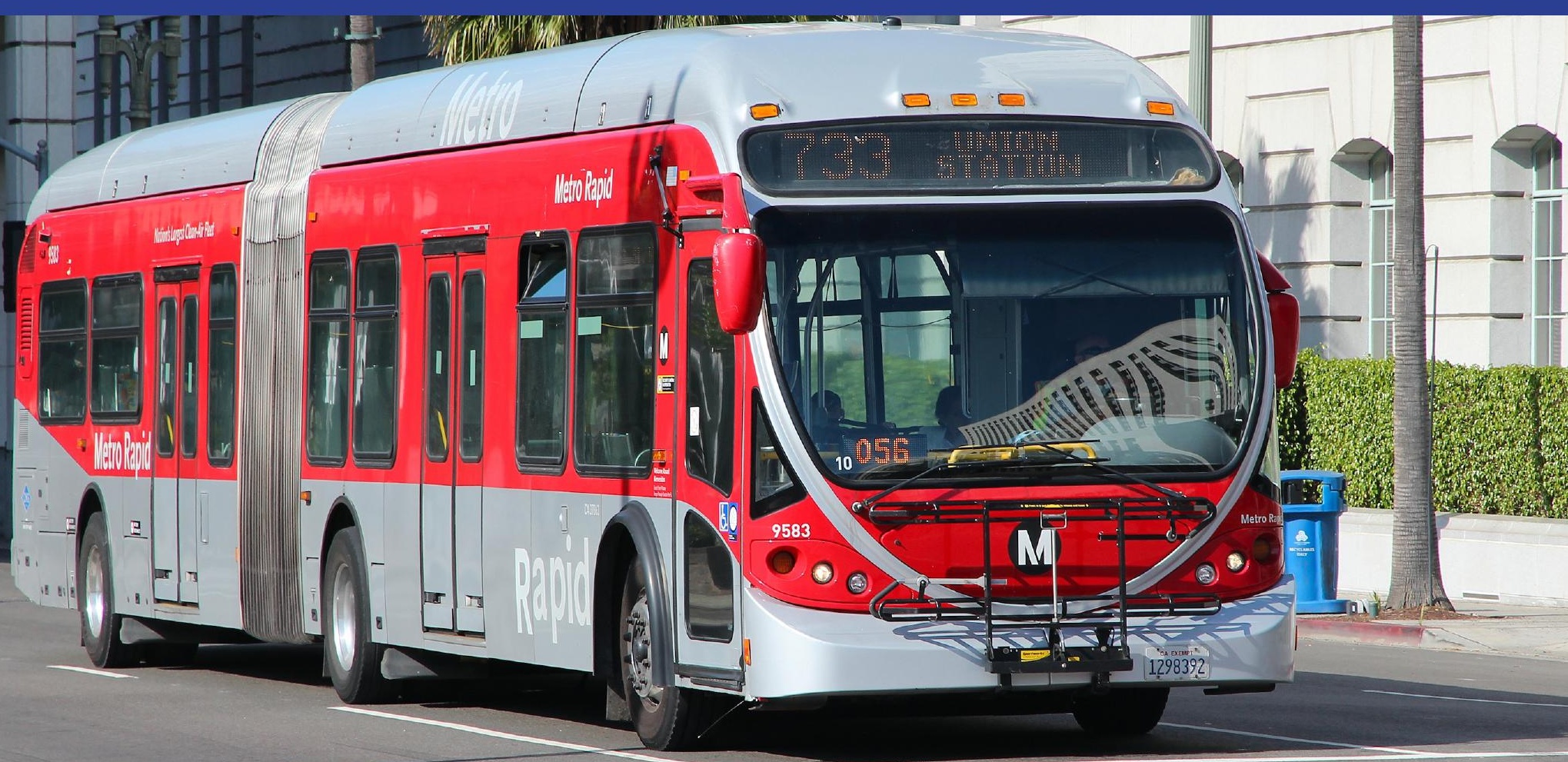

The Link between Transit Station Proximity and Real Estate Rents, Jobs, People and Housing with Transit and Land Use Planning Implications

Arthur C. Nelson, Ph.D. Robert Hibberd, Ph.D.

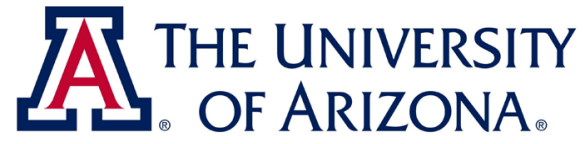




\title{
The Link between Transit Station Proximity and Real Estate Rents, Jobs, People and Housing with Transit and Land Use Planning Implications
}

\author{
Final Report
}

\author{
NITC-RR-1103 \\ by \\ Arthur C. Nelson \\ Robert Hibberd \\ With Matt Dixon \\ University of Arizona
}

for

National Institute for Transportation and Communities (NITC)

P.O. Box 751

Portland, OR 97207
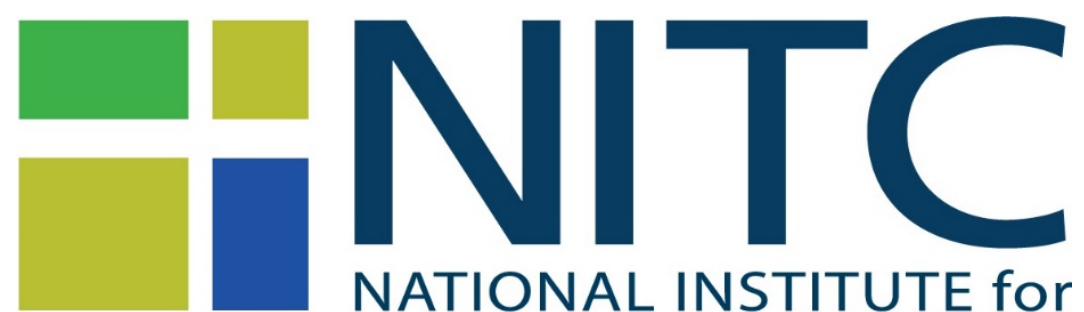

NATIONAL INSTITUTE for TRANSPORTATION and COMMUNITIES

November 2019 


\begin{tabular}{|c|c|c|c|c|}
\hline \multicolumn{5}{|c|}{ Technical Report Documentation Page } \\
\hline $\begin{array}{l}\text { 1. Report No. } \\
\text { NITC-RR-1103 }\end{array}$ & \multicolumn{2}{|l|}{ 2. Government Accession No. } & \multicolumn{2}{|c|}{ 3. Recipient's Catalog No. } \\
\hline \multicolumn{3}{|l|}{ 4. Title and Subtitle } & \multicolumn{2}{|c|}{ 5. Report Date } \\
\hline \multicolumn{3}{|c|}{ The Link between Transit Station Proximity and Real Estate Rents, Jobs, People } & \multicolumn{2}{|c|}{ November 30, 2019} \\
\hline & \multirow{2}{*}{\multicolumn{2}{|c|}{ 6. Performing Organization Code }} \\
\hline & & & & \\
\hline \multicolumn{3}{|l|}{ 7. Author(s) } & \multicolumn{2}{|c|}{$\begin{array}{l}\text { 8. Performing Organization Report } \\
\text { No. }\end{array}$} \\
\hline \multirow{2}{*}{\multicolumn{3}{|c|}{$\begin{array}{l}\text { 9. Performing Organization Name and Address } \\
\text { Arthur C. Nelson } \\
\text { College of Architecture, Planning and Landscape Architecture } \\
\text { University of Arizona } \\
1040 \text { N. Olive Road } \\
\text { Tucson, Arizona } 85721\end{array}$}} & \multicolumn{2}{|c|}{ 10. Work Unit No. (TRAIS) } \\
\hline & & & \multicolumn{2}{|c|}{ 11. Contract or Grant No. } \\
\hline \multirow{3}{*}{\multicolumn{3}{|c|}{$\begin{array}{l}\text { 12. Sponsoring Agency Name and Address } \\
\text { National Institute for Transportation and Communities (NITC) } \\
\text { P.O. Box } 751 \\
\text { Portland, Oregon } 97207\end{array}$}} & \multicolumn{2}{|c|}{ 13. Type of Report and Period } \\
\hline & & & \multicolumn{2}{|c|}{ Final Report } \\
\hline & & & \multicolumn{2}{|c|}{ 14. Sponsoring Agency Code } \\
\hline \multicolumn{5}{|l|}{ 15. Supplementary Notes } \\
\hline \multicolumn{5}{|l|}{ Photo by tupungato on iStockphoto.com } \\
\hline \multicolumn{5}{|l|}{ 16. Abstract } \\
\hline \multicolumn{5}{|c|}{ 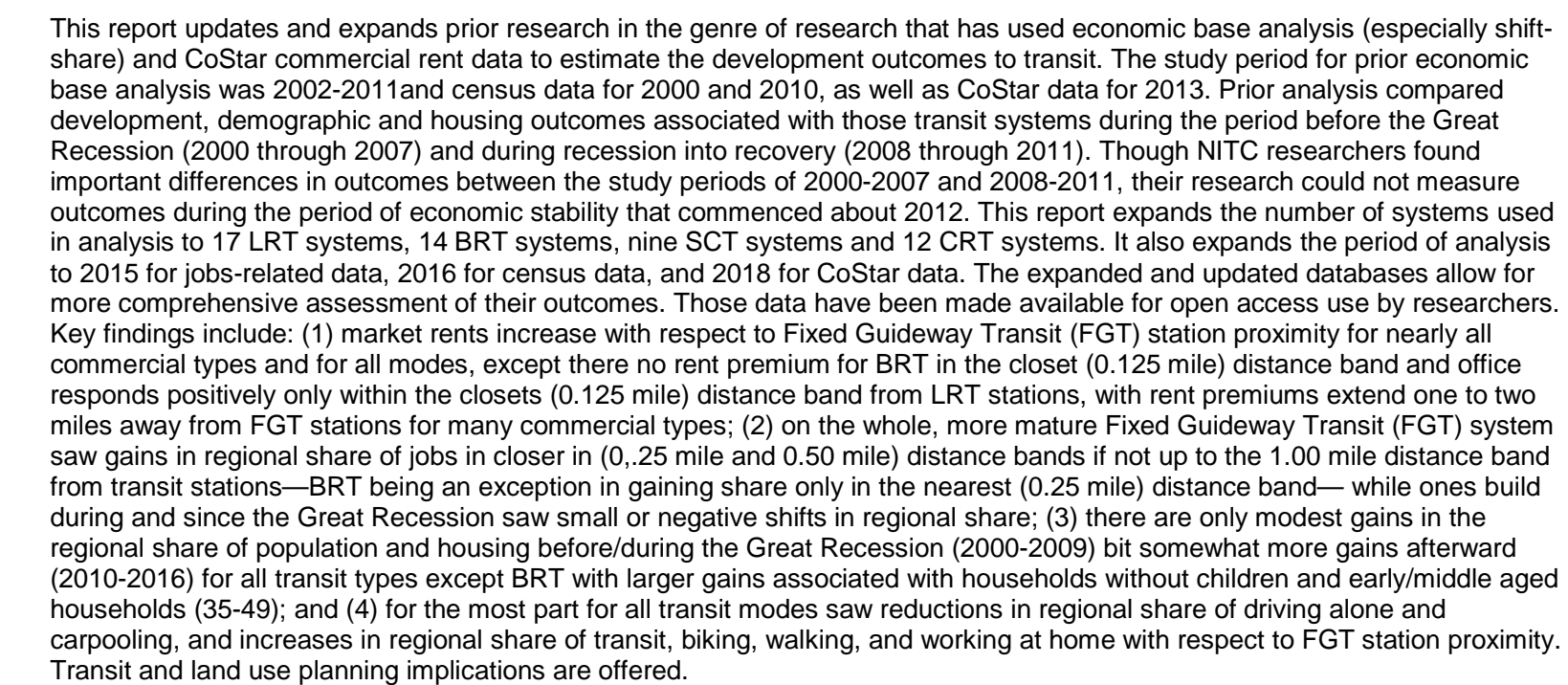 } \\
\hline \multicolumn{2}{|c|}{$\begin{array}{l}\text { 17. Key Words } \\
\text { Light Rail Transit, Bus Rapid Transit, Streetcar, Commuter Rail, } \\
\text { Express Bus, Employment, GIS Model Builder, NAICS, Industry, } \\
\text { Sectors, Economic Development, Longitudinal-Household Employment } \\
\text { Database, Census, American Community Survey, Employment } \\
\text { Change, Transportation Planning, Land Use Planning, Real Estate } \\
\text { Rents and Transit Accessibility, Jobs-Housing Balance, Jobs-Labor } \\
\text { Force Balance, Good Station Location and Design. }\end{array}$} & $\begin{array}{l}\text { 18. Distributi } \\
\text { No restrict } \\
\text { www.nitc.l }\end{array}$ & Copies av & ITC: \\
\hline 19. Security Classification (of this report) & $\begin{array}{l}\text { 20. Security Classification (of } \\
\text { page) }\end{array}$ & & of Pages & $\begin{array}{l}\text { 22. Price } \\
\text { Free }\end{array}$ \\
\hline
\end{tabular}




\section{ACKNOWLEDGEMENTS}

The authors acknowledge assistance from Laura Jensen as well as support by the College of Architecture, Planning and Landscape Architecture at the University of Arizona.

\section{DISCLAIMER}

The contents of this report reflect the views of the authors, who are solely responsible for the facts and the accuracy of the material and information presented herein. This document is disseminated under the sponsorship of the U.S. Department of Transportation University Transportation Centers Program in the interest of information exchange. The U.S. Government assumes no liability for the contents or use thereof. The contents do not necessarily reflect the official views of the U.S. Government. This report does not constitute a standard, specification, or regulation.

\section{RECOMMENDED CITATION}

Nelson, Arthur C. and Robert Hibberd. The Link between Transit Station Proximity and Real Estate Rents, Jobs, People and Housing with Transit and Land Use Planning Implications. NITC-RR-1103. Portland, OR: Transportation Research and Education Center (TREC), 2019. 


\section{TABLE OF CONTENTS}

1.0 INTRODUCTION TO RESEARCH INTO THE LINK BETWEEN TRANSIT
STATION PROXIMITY AND COMMERCIAL RENTS, JOBS, PEOPLE AND
HOUSING WITH IMPLICATIONS FOR TRANSIT AND LAND USE PLANNING..... 45
1.1
OVERVIEW

2.0 THE LINK BETWEEN TRANSIT STATION PROXIMITY AND COMMERCIAL REAL ESTATE RENTS WITH IMPLICATIONS FOR TRANSIT AND LAND USE PLANNING ........................................................................................................................ 57

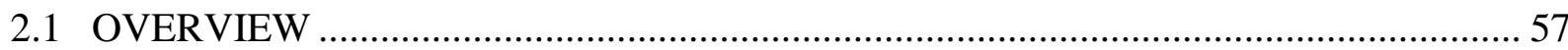

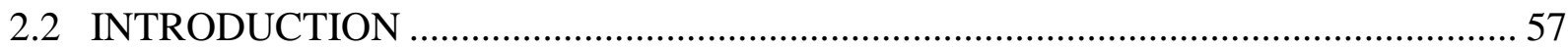

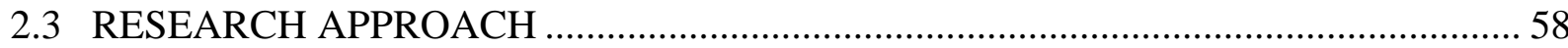

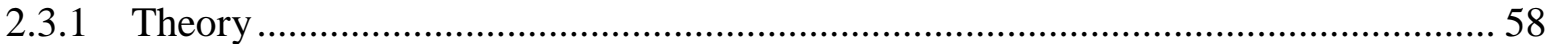

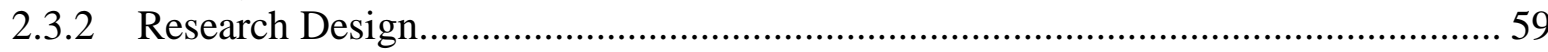

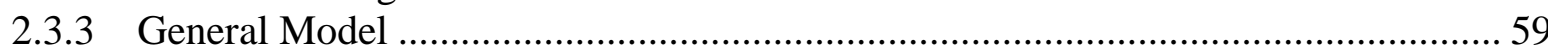

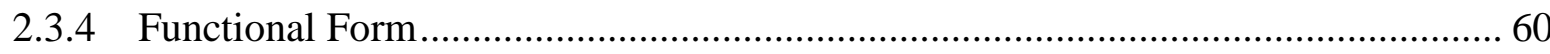

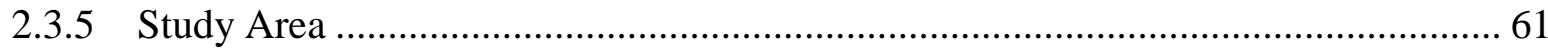

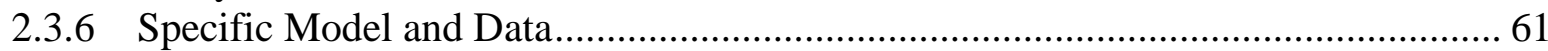

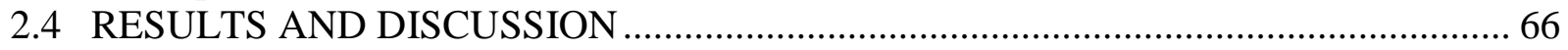

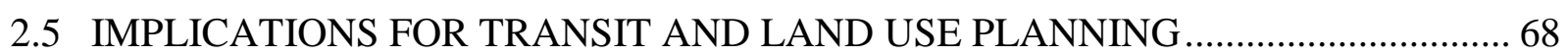

3.0 THE VARIATION OF ECONOMIC DEVELOPMENT WITH RESPECT TO FIXED ROUTE TRANSIT STATION PROXIMITY BEFORE, DURING AND AFTER THE GREAT RECESSION .......................................................................................................... 85

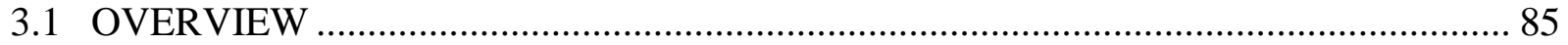

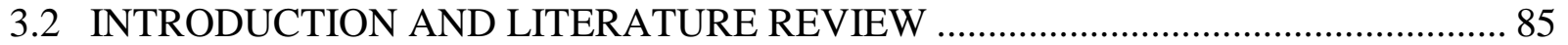

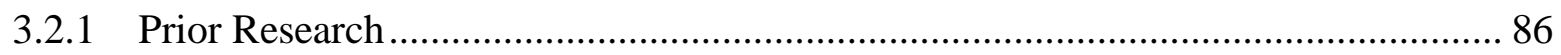

3.2.2 The Nelson-Stoker-Hibberd Resilience Hypothesis .................................................. 86

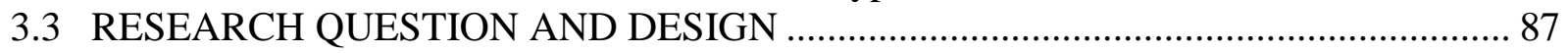

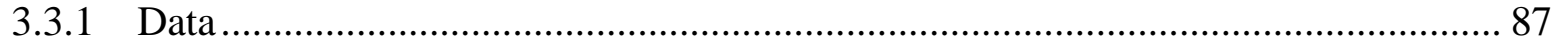

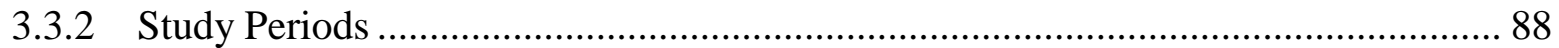

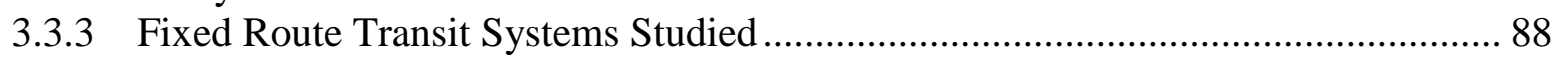

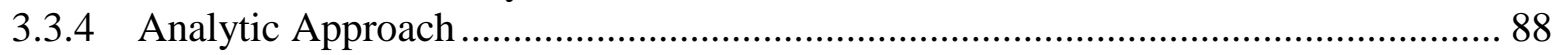

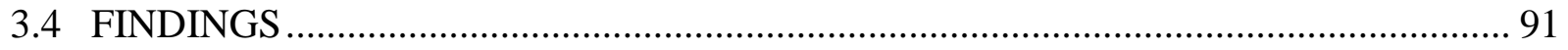

3.4.1 Light Rail Transit Station Proximity and Worker Change ........................................ 91

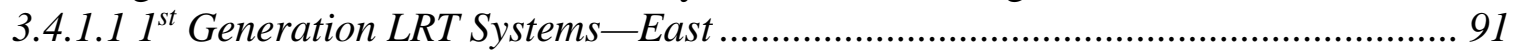

3.4.1.2 $1^{\text {st }}$ Generation LRT Systems - West.................................................................. 93

3.4.1.3 $2^{\text {nd }}$ Generation LRT Systems -West................................................................... 94

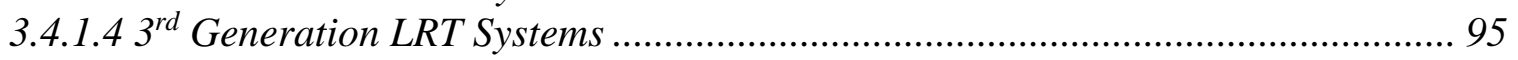


3.4.2 Bus Rapid Transit Station Proximity and Worker Change ................................... 96

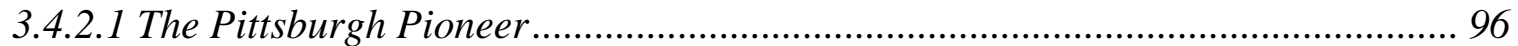

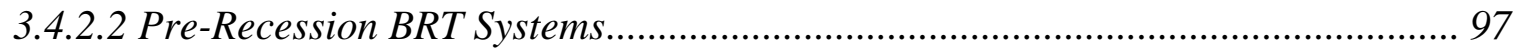

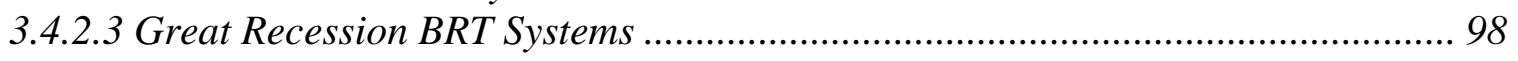

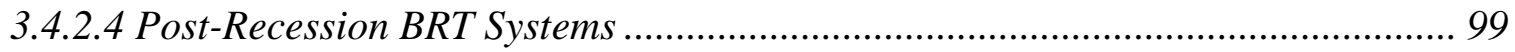

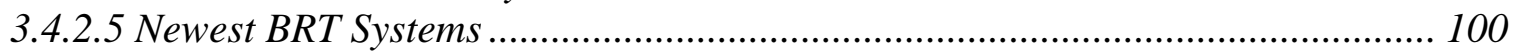

3.4.3 Streetcar Transit Station Proximity and Worker Change ..................................... 101

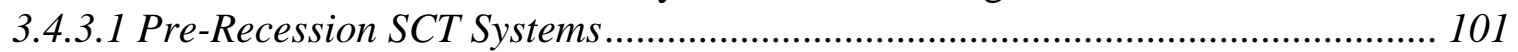

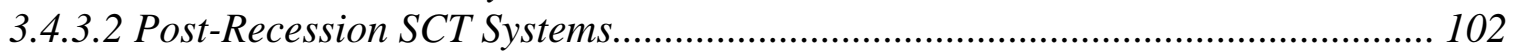

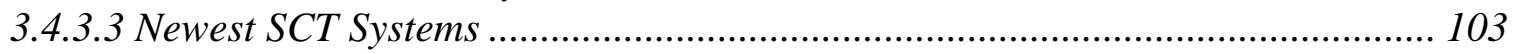

3.4.4 Commuter Rail Transit Station Proximity and Worker Change............................ 104

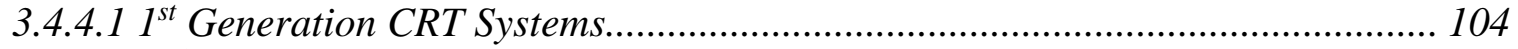

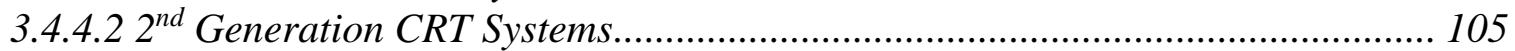

3.5 OVERALL IMPLICATIONS FOR TRANSIT AND LAND USE PLANNING .......... 106

4.0 THE LINK BETWEEN TRANSIT STATION PROXIMITY AND CHANGE IN WORKERS BY ECONOMIC GROUPS AND WAGES SINCE THE GREAT

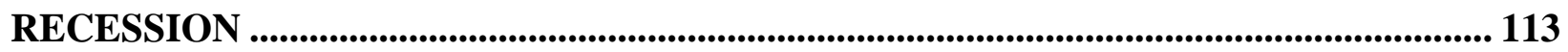

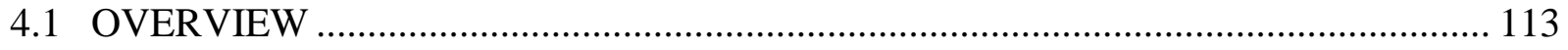

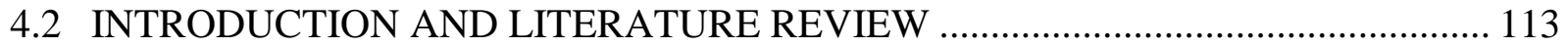

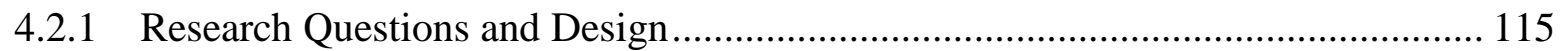

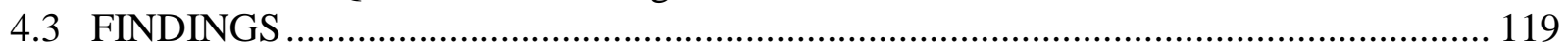

4.3.1 Economic Group Findings ...................................................................... 119

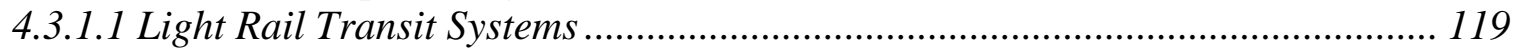

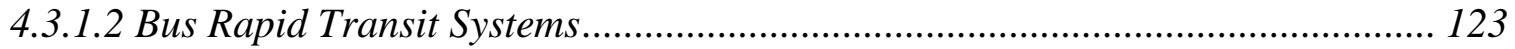

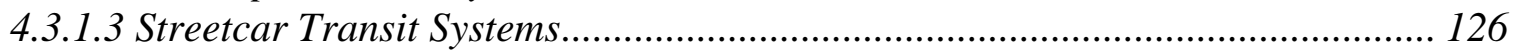

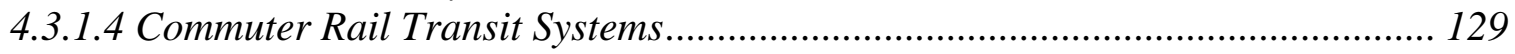

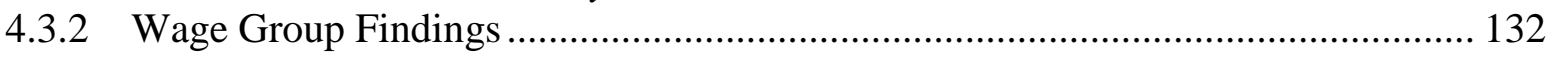

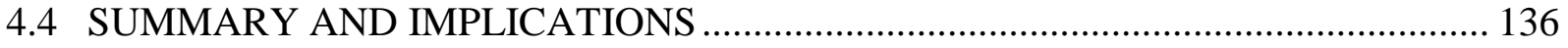

5.0 THE LINK BETWEEN TRANSIT STATIONS AND PEOPLE, HOUSEHOLD

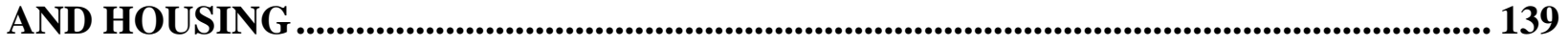

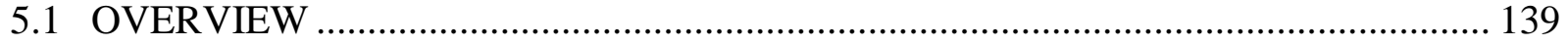

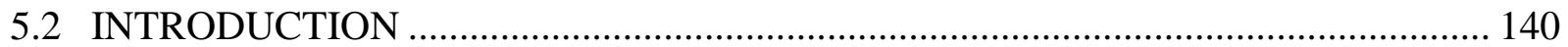

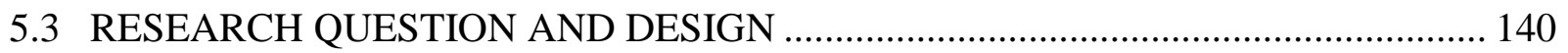

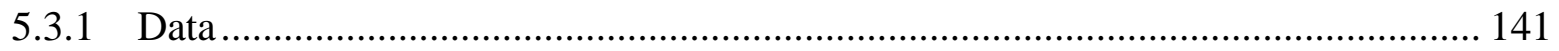

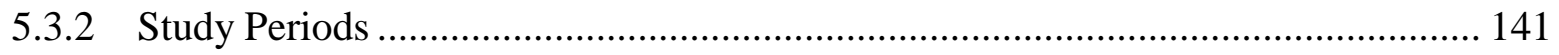

5.3.3 Fixed Guideway Transit Systems Studied ........................................................ 141

5.3.4 Analytic Approach ................................................................................ 143

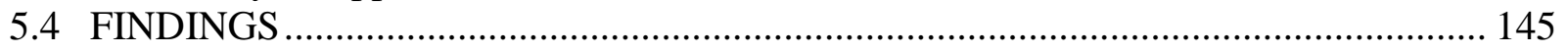

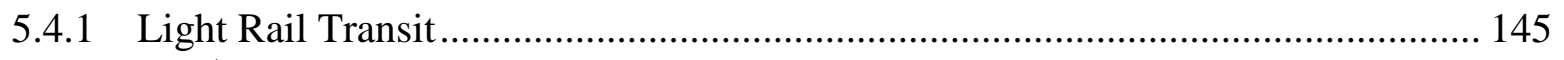

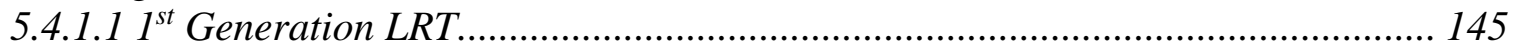

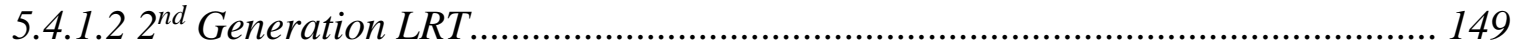

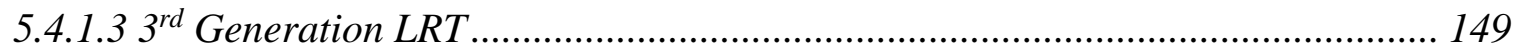

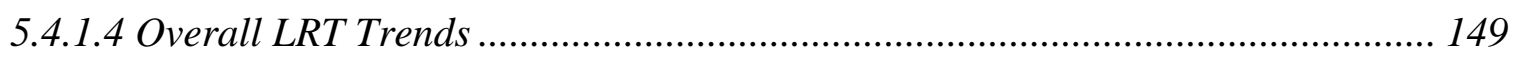

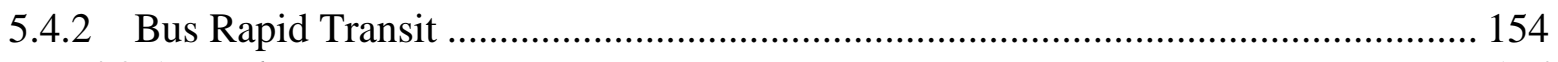

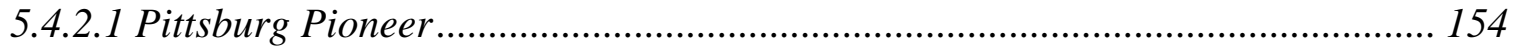

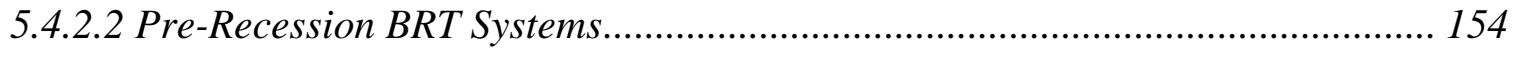




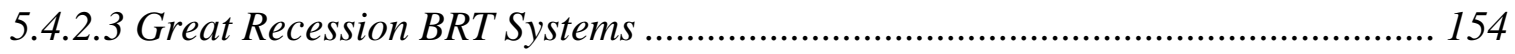

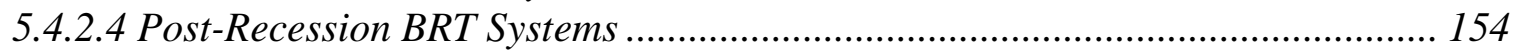

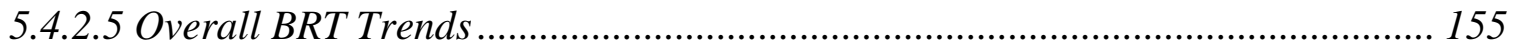

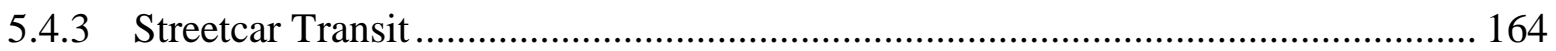

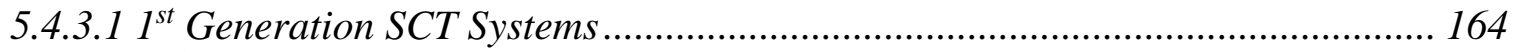

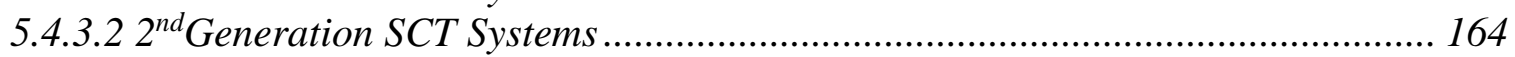

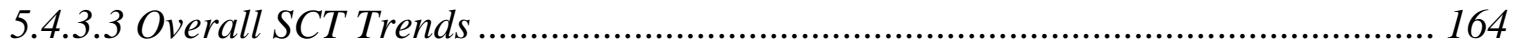

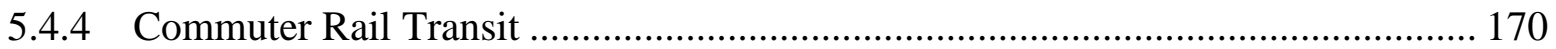

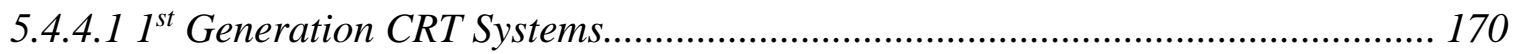

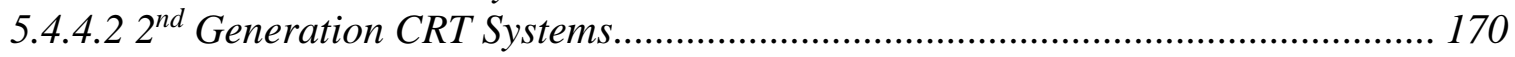

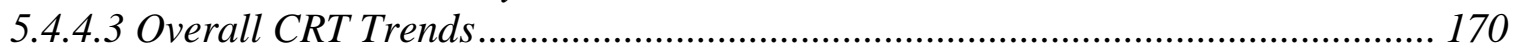

5.5 IMPLICATIONS FOR TRANSIT AND LAND USE PLANNING …………............... 175

6.0 THE LINK BETWEEN TRANSIT STATION PROXIMITY AND MODE CHOICE TO WORK, WORKING AT HOME, AND OWNING NO VEHICLES............................. 179

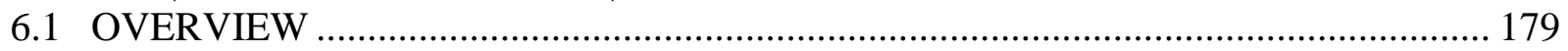

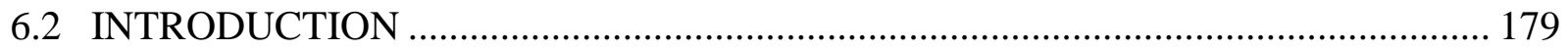

6.3 RESEARCH QUESTION AND DESIGN …………............................................. 181

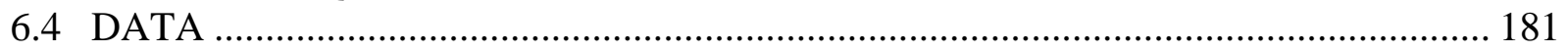

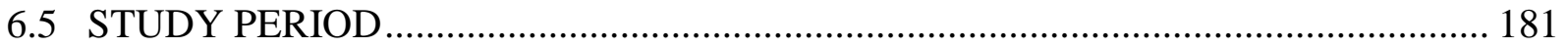

6.6 FIXED ROUTE TRANSIT SYSTEMS STUDIED .................................................. 181

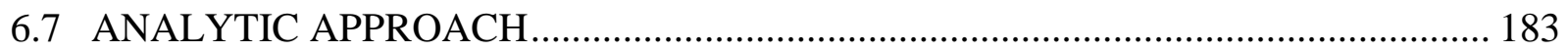

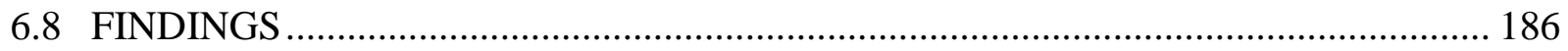

6.9 IMPLICATIONS FOR TRANSIT AND LAND USE PLANNING ………………........ 186

7.0 THE LINK BETWEEN JOBS-WORKER BALANCE BY INCOME AND ECONOMIC GROUP WITH RESPECT TO TRANSIT STATION PROXIMITY .......... 197

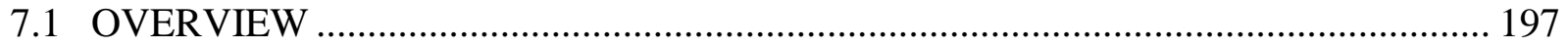

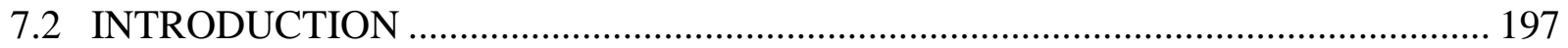

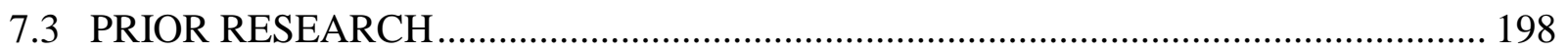

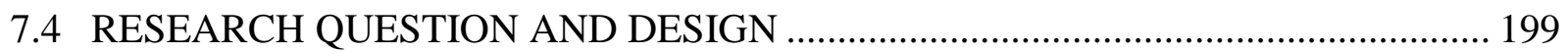

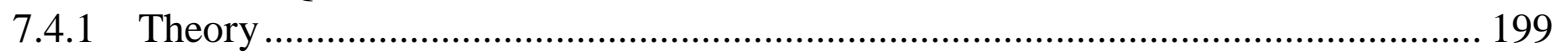

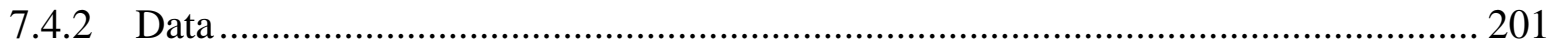

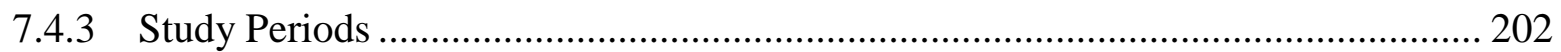

7.4.4 Fixed Route Transit Systems Studied ............................................................... 202

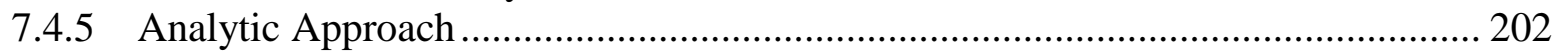

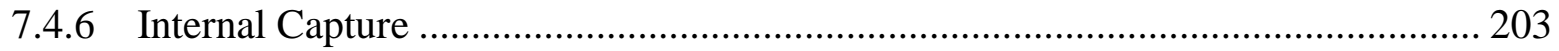

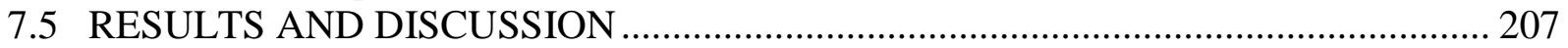

7.5.1 Light Rail Transit (LRT) Jobs-Worker Balance Before, During and After the Great

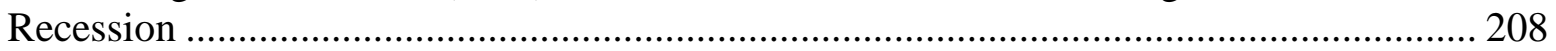

7.5.2 Bus Rapid Transit (BRT) Employment-Worker Balance Before, During and After the Great Recession................................................................................................ 211

7.5.3 Streetcar Transit (SCT) Jobs-Worker Balance Before, During and After the Great Recession ................................................................................................................ 214 7.5.4 Commuter Rail Transit (CRT) Jobs-Worker Balance Before, During and After the Great Recession ................................................................................................................ 216

7.6 IMPLICATIONS FOR TRANSIT AND LAND USE PLANNING ……….................... 219

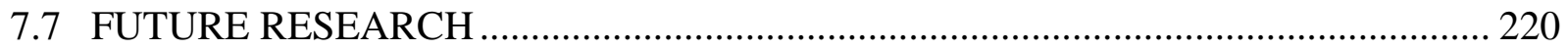




\subsection{THE LINK BETWEEN FIXED ROUTE TRANSIT STATION PLANNING AND}

DESIGN, AND DEVELOPMENT OUTCOMES.................................................................... 223

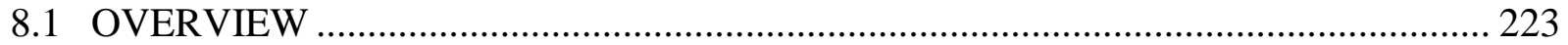

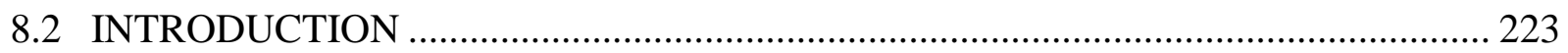

8.2.1 Transit and the Theory of Urban Development ....................................................... 223

8.2.2 Principles of Transit Station Planning and Design to Advance Development ....... 224

8.2.3 Negative Externalities and Development Outcomes ............................................. 225

8.3 TOWARD A TYPOLOGY OF GOOD, BAD AND UGLY TRANSIT STATION

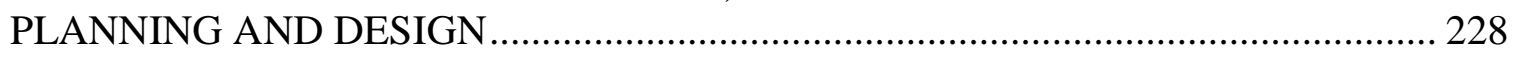

8.4 APPLICATIONS TO SELECTED FRT SYSTEMS ..................................................... 233

8.5 IMPLICATIONS FOR TRANSIT AND LAND USE PLANNNIG ……………............ 235

9.0 THE LINK BETWEEN HOUSEHOLD TRANSPORTATION COST AND

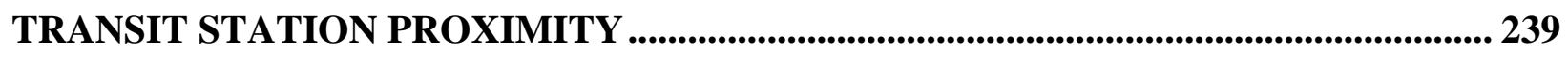

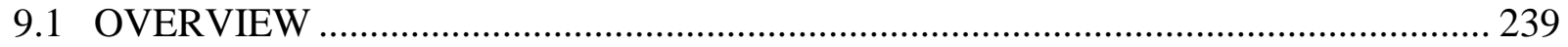

9.2 INTRODUCTION AND LITERATURE REVIEW …………………………….......... 239

9.3 RESEARCH QUESTION AND DESIGN ………............................................... 241

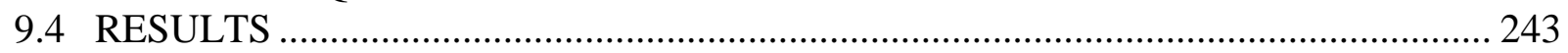

9.5 IMPLICATIONS FOR TRANSIT AND LAND USE PLANNING ……………........... 252

10.0 THE (OVERLOOKED) LINK BETWEEN EXPRESS BUS STATIONS AND COMMERCIAL RENTS WITH IMPLICATIONS FOR TRANSIT AND LAND USE PLANNING ...................................................................................................................... 255

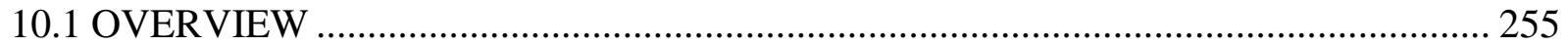

10.2 INTRODUCTION AND LITERATURE REVIEW ………………………................. 255

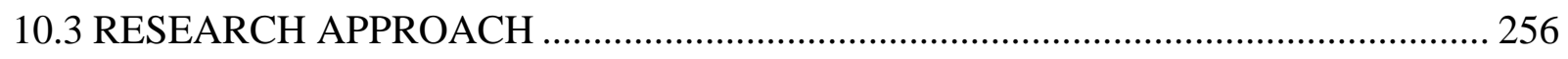

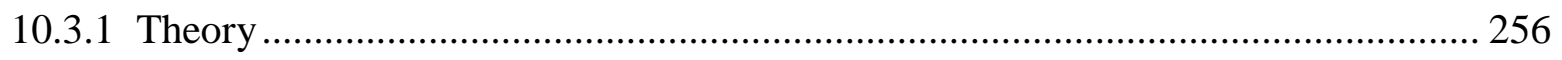

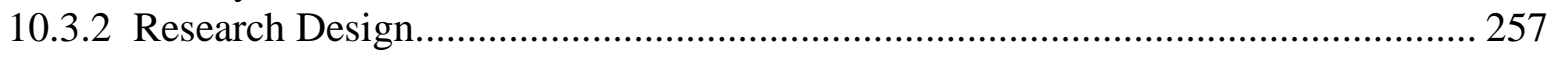

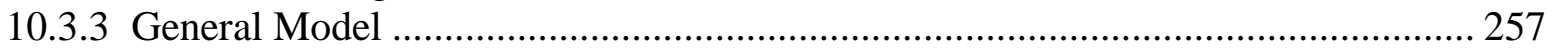

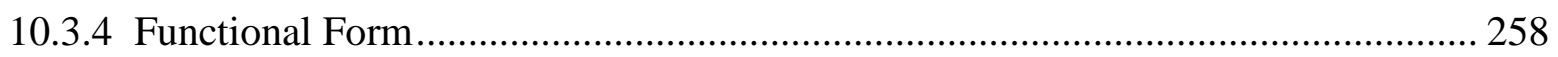

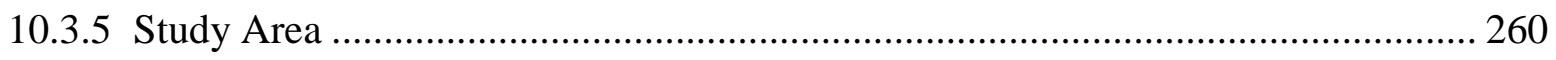

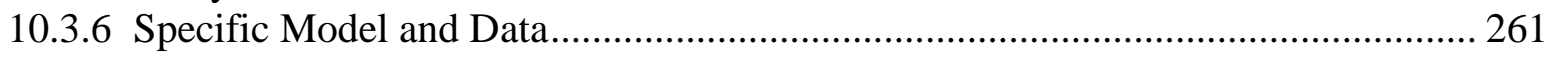

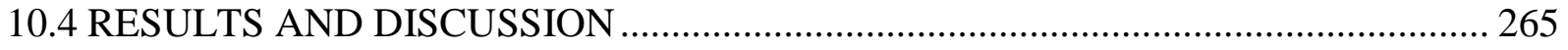

10.5 IMPLICATIONS FOR TRANSIT AND LAND USE PLANNING ………….............. 272

\subsection{THE LINK BETWEEN TRANSIT AND LAND USE PLANNING TO MEET} AMERICA'S MARKET DEMAND FOR TRANSIT STATION PROXIMITY ................ 277

\section{LIST OF TABLES}

Table ES.1: Fixed Route Transit (FRT) Systems Studied ........................................................... 6

Table ES.2: Significant Distance Band Coefficients with Respect to LRT, BRT, SCT and CRT

Station Proximity for Office, Multifamily and Retail Rents................................................... 9

Table ES.3: Post-Recession Share of Transit Region Worker Change by Distance Band and Ratio of Worker Share to Distance Band UA Share of Transit Region Urban Area ...................... 13

Table ES.4: Combinations of NAICS Sectors into Economic Groups for Analysis ...................... 15

Table ES.5: Economic Concentration Trend by Distance Band from FRT Stations, 2011 to 2015 
Table ES.5: Economic Concentration Trend by Distance Band from FRT Stations, 2011 to 2015-

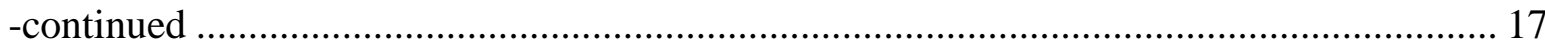

Table ES.6: Allocation of Workers by Lower-, Middle- and Upper-Wage Category .................. 20

Table ES.7: Fixed Route Transit Systems Studied .................................................................. 27

Table ES.8. LRT Jobs-Worker Balance Ratios and Change by Wage and Sector Group Across Years Before, During, and After Great Recession........................................................ 28

Table ES.8 LRT Jobs-Worker Balance Ratios and Change by Wage and Sector Group Across Years Before, During, and After Great Recession (continued) ........................................ 29

Table ES.9 BRT Jobs-Worker Balance Ratios and Change by Wage and Sector Group Across Years Before, During, and After Great Recession.......................................................... 30

Table ES.10 SCT Jobs-Worker Balance Ratios and Change by Wage and Sector Group Across Years Before, During, and After Great Recession....................................................... 32

Table ES.11 CRT Jobs-Worker Balance Ratios and Change by Wage and Sector Group Across Years Before, During, and After Great Recession............................................................. 33

Table ES.12: Comparing Market Rent Typology to LRT System Mean Walk-Bike-Transit Scores

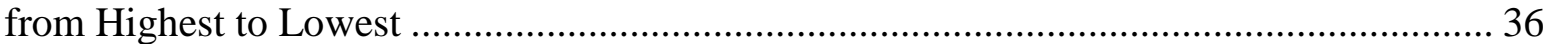

Table 2.1: Metropolitan Area Fixed Guideway Transit Systems ........................................... 61

Table 2.2: Variables, Data Sources, and Predicted Association with Respect to Rent................. 65

Table 2.3: Commercial Rent Regression Equations with Respect to Light Rail Transit Station

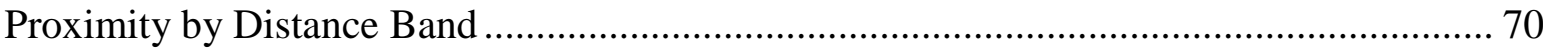

Table 2.4: Commercial Rent Regression Equations with Respect to Bus Rapid Transit Station

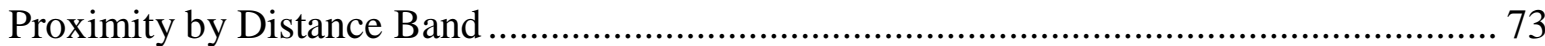

Table 2.5: Streetcar Commercial Rent Regression Equations with Respect to Streetcar Station

Proximity by Distance Band ............................................................................... 76

Table 2.6: Streetcar Commercial Rent Regression Equations with Respect to CRT Station

Proximity by Distance Band ...................................................................................... 79

Table 3.1: Fixed Route Transit (FRT) Systems Studies Using Economic Base--Shift-Share

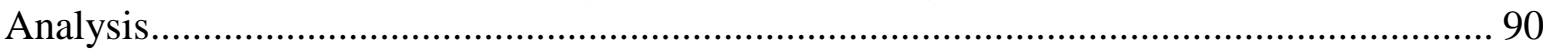

Table 3.3: Change in Total Workers by Time Period, $1^{\text {st }}$ Generation East LRT Systems........... 92

Table 3.4: Change in Total Workers by Time Period, $1^{\text {st }}$ Generation West LRT Systems .......... 93

Table 3.5: Change in Total Workers by Time Period, $2^{\text {nd }}$ Generation West LRT Systems ......... 95

Table 3.6: Change in Total Workers by Time Period, $3^{\text {rd }}$ Generation LRT Systems .................. 96

Table 3.7: Change in Total Workers by Time Period, Pittsburgh BRT System......................... 97

Table 3.8: Change in Total Workers by Time Period, Pre-Recession BRT Systems .................. 98

Table 3.9: Change in Total Workers by Time Period, Great Recession BRT Systems................ 99

Table 3.10: Change in Total Workers by Time Period, Great Recession BRT Systems............ 100

Table 3.11: Change in Total Workers by Time Period, Pre-Recession SCT Systems ............... 101

Table 3.12: Change in Total Workers by Time Period, Post-Recession SCT Systems............. 102

Table 3.13: Change in Total Workers by Time Period, $1^{\text {st }}$ Generation CRT Systems ............... 105

Table 3.14: Change in Total Workers by Time Period, $2^{\text {nd }}$ Generation CRT Systems .............. 106

Table 3.15: Post-Recession Share of Transit Region Worker Change by Distance Band and Ratio

of Worker Share to Distance Band UA Share of Transit Region UA ............................. 108

Table 4.1: Combinations of NAICS Sectors into Economic Groups for Analysis.................... 116

Table 4.2: Fixed Route Transit Systems Used in Study ....................................................... 117

Table 4.3: Allocation of Workers by Lower-, Middle- and Upper-Wage Category................... 118 
Table 4.4: Change in Workers by Economic Group and Distance Band from LRT Station, 20112015

Table 4.5: Location Quotients by Economic Group for 2015 and LQ Trends 2011-2015 by Economic Group by Distance Band from LRT Station. 122

Table 4.6: Change in Workers by Economic Group and Distance Band from BRT Station, 20112015

Table 4.7: Location Quotients by Economic Group for 2015 and LQ Trends 2011-2015 by Economic Group by Distance Band from BRT Station

Table 4.8: Change in Workers by Economic Group and Distance Band from SCT Station, 20112015

Table 4.9: Location Quotients by Economic Group for 2015 and LQ Trends 2011-2015 by Economic Group by Distance Band from SCT Station

Table 4.10: Change in Workers by Economic Group and Distance Band from CRT Station, 2011-2015 130

Table 4.11: Location Quotients by Economic Group for 2015 and LQ Trends 2011-2015 by Economic Group by Distance Band from CRT Station

Table 4.12: Change in Workers by Wage Group and Distance Band from LRT Station, 20112015

Table 4.13: Change in Workers by Wage Group and Distance Band from BRT Station, 20112015

Table 4.14: Change in Workers by Wage Group and Distance Band from SCT Station, 20112015

Table 4.15: Change in Workers by Wage Group and Distance Band from CRT Station, 20112015

Table 4.16: Summary Change in Workers by Wage Group for 0.125 and 0.50 Distance Bands with Transit Region Share of Change for All Stations, 2011-2015

Table 5.1: Fixed Guideway Transit Systems Used in Analysis 142

Table 5.2a(i): st $^{\text {st }}$ Generation Light Rail Transit People and Housing Shift-Share Results for Transit Station Areas 2000-2009 and 2010-2016

Table 5.2a(ii): $1^{\text {st }}$ Generation Light Rail Transit People and Housing Shift-Share Results for Transit Station Areas 2000-2009 and 2010-2016

Table 5.2b(i): ${ }^{\text {nd }}$ Generation Light Rail Transit People and Housing Shift-Share Results for Transit Station Areas 2000-2009 and 2010-2016

Table 5.2b(ii): $2^{\text {nd }}$ Generation Light Rail Transit People and Housing Shift-Share Results for Transit Station Areas 2000-2009 and 2010-2016

Table 5.2c(i): $3^{\text {rd }}$ Generation Light Rail Transit People and Housing Shift-Share Results for Transit Station Areas 2000-2009 and 2010-2016

Table 5.2c(ii): $3^{\text {rd }}$ Generation Light Rail Transit People and Housing Shift-Share Results for Transit Station Areas 2000-2009 and 2010-2016

Table 5.3a(i): Pittsburgh Pioneer Bus Rapid Transit People and Housing Shift-Share Results for Transit Station Areas 2000-2009 and 2010-2016

Table 5.3a(ii): Pittsburgh Pioneer Bus Rapid Transit People and Housing Shift-Share Results for Transit Station Areas 2000-2009 and 2010-2016 157

Table 5.3b(i): Pre-Recession Bus Rapid Transit People and Housing Shift-Share Results for Transit Station Areas 2000-2009 and 2010-2016 
Table 5.3b(ii): Pre-Recession Bus Rapid Transit People and Housing Shift-Share Results for

Transit Station Areas 2000-2009 and 2010-2016....

Table 5.3c(i): Great Recession Bus Rapid Transit People and Housing Shift-Share Results for

Transit Station Areas 2000-2009 and 2010-2016 .......................................................... 160

Table 5.3c(ii): Great Recession Bus Rapid Transit People and Housing Shift-Share Results for

Transit Station Areas 2000-2009 and 2010-2016 ......................................................... 161

Table 5.3d(i): Post-Recession Bus Rapid Transit People and Housing Shift-Share Results for

Transit Station Areas 2000-2009 and 2010-2016 ........................................................ 162

Table 5.3d(ii): Post-Recession Bus Rapid Transit People and Housing Shift-Share Results for

Transit Station Areas 2000-2009 and 2010-2016 ......................................................... 163

Table 5.4a(i): $1^{\text {st }}$ Generation Streetcar Transit People and Housing Shift-Share Results for

Transit Station Areas 2000-2009 and 2010-2016 ......................................................... 165

Table 5.4a(ii): $1^{\text {st }}$ Generation Streetcar Transit People and Housing Shift-Share Results for

Transit Station Areas 2000-2009 and 2010-2016 ........................................................... 166

Table 5.4b(i): $2^{\text {nd }}$ Generation Streetcar Transit People and Housing Shift-Share Results for

Transit Station Areas 2000-2009 and 2010-2016 ....................................................... 167

Table 5.4b(ii): $2^{\text {nd }}$ Generation Streetcar Transit People and Housing Shift-Share Results for

Transit Station Areas 2000-2009 and 2010-2016 ........................................................... 168

Table 5.5a(i): $1^{\text {st }}$ Generation Commuter Rail Transit People and Housing Shift-Share Results for

Transit Station Areas 2000-2009 and 2010-2016

Table 5.5a(ii): $1^{\text {st }}$ Generation Commuter Rail Transit People and Housing Shift-Share Results for Transit Station Areas 2000-2009 and 2010-2016 ......................................................... 172

Table 5.5b(i): $2^{\text {nd }}$ Generation Commuter Rail Transit People and Housing Shift-Share Results for

Transit Station Areas 2000-2009 and 2010-2016 ........................................................ 173

Table 5.5b(ii): $2^{\text {nd }}$ Generation Commuter Rail Transit People and Housing Shift-Share Results

for Transit Station Areas 2000-2009 and 2010-2016 ................................................. 174

Table 6.1: Fixed Route Transit Systems Used in Analysis..................................................... 182

Table 6.2: Shift in Share of Commuting Mode Choice, Workers Working at Home and

Household Vehicle Ownership with Respect to Light Rail Transit Proximity, 2010-2016 187

Table 6.3: Shift in Share of Commuting Mode Choice, Workers Working at Home and

Household Vehicle Ownership with Respect to Bus Rapid Transit Proximity, 2010-2016189

Table 6.4: Shift in Share of Commuting Mode Choice, Workers Working at Home and

Household Vehicle Ownership with Respect to Streetcar Transit Proximity, 2010-2016 . 191

Table 6.5: Shift in Share of Commuting Mode Choice, Workers Working at Home and

Household Vehicle Ownership with Respect to Commuter Rail Transit Proximity, 20102016.

Table 7.1: Allocation of Jobs by Lower-, Middle-, and Upper-Wage Category ........................ 203

Table 7.2: Combinations of NAICS Sectors into Economic Groups for Analysis .................... 205

Table 7.3: Fixed Route Transit (FRT) Systems Studied for Employment-Worker Balance ...... 206

Table 7.4. LRT Jobs-Worker Balance Ratios and Change by Wage and Sector Group Across

Years Before, During, and After Great Recession...

Table 7.4: LRT Jobs-Worker Balance Ratios and Change by Wage and Sector Group Across

Years Before, During, and After Great Recession (continued) .................................... 210

Table 7.5. BRT Jobs-Worker Balance Ratios and Change by Wage and Sector Group Across

Years Before, During, and After Great Recession 
Table 7.5. BRT Jobs-Worker Balance Ratios and Change by Wage and Sector Group Across Years Before, During, and After Great Recession (continued) ...................................... 213

Table 7.6.: SCT Jobs-Worker Balance Ratios and Change by Wage and Sector Group Across Years Before, During, and After Great Recession....................................................... 215

Table 7.7: CRT Jobs-Worker Balance Ratios and Change by Wage and Sector Group Across Years Before, During, and After Great Recession......................................................... 217

Table 8.1: Annual Office Rents per Square Foot with Respect to LRT Station Proximity, Distance Band Regression Coefficients.

Table 8.2: Comparing Market Rent Typology to LRT System Mean Walk-Bike-Transit Scores

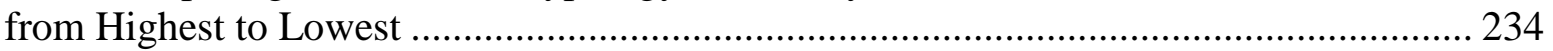

Table 9.1: FTR Systems Used in Analysis ........................................................................ 243

Table 9.2: The Association between Transit Station Proximity and Typical Regional Household Transportation Costs as a Percent of Regional Median Household Income, Light Rail Systems 244

Table 9.2: The Association between Transit Station Proximity and Typical Regional Household

Transportation Costs as a Percent of Regional Median Household Income, Light Rail

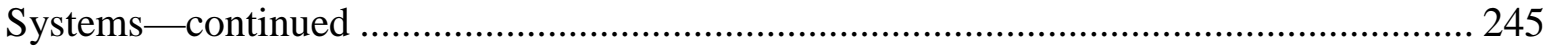

Table 9.3: The Association between Transit Station Proximity and Typical Regional Household Transportation Costs as a Percent of Regional Median Household Income, Bus Rapid Transit Systems 246

Table 9.3: The Association between Transit Station Proximity and Typical Regional Household Transportation Costs as a Percent of Regional Median Household Income, Bus Rapid Transit Systems_continued 246

Table 9.3: The Association between Transit Station Proximity and Typical Regional Household Transportation Costs as a Percent of Regional Median Household Income, Streetcar Transit Systems 247

Table 9.4: Regional Typical Household Budget Savings with Respect to LRT, BRT and SCT Station Proximity ........................................................................................... 248

Table 10.1: Metropolitan Area Express Bus Transit Systems Analyzed.................................. 260

Table 10.2: Variables, Data Sources, and Predicted Association with Respect to Rent per Square Foot 264

Table 10.3: The Link between XBT Station Proximity and Office, Multifamily and Retail Rents per Square Foot ............................................................................................. 267

Table 10.3: The Link between XBT Station Proximity and Office, Multifamily and Retail Rents per Square Foot—continued ...................................................................................... 268

Table 10.3: The Link between XBT Station Proximity and Office, Multifamily and Retail Rents per Square Foot — continued ........................................................................................ 269

Table 10.3: The Link between XBT Station Proximity and Office, Multifamily and Retail Rents per Square Foot — continued ................................................................................ 270

\section{LIST OF FIGURES}

Figure ES.1: Dallas Area Rapid Transit light rail ............................................................... 2

Figure ES.2: Portland, Oregon, streetcar ........................................................................ 3

Figure ES.3: Utah Transit Authority Frontrunner commuter rail ........................................... 4 
Figure ES.4: Lane County Transit Emerald Express bus rapid transit serving Eugene-Springfield,

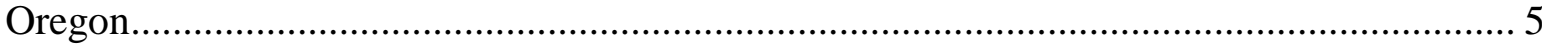

Figure ES.1: Significant Distance Band Coefficients with Respect to LRT, BRT, SCT and CRT Station Proximity for Office, Multifamily and Retail Rents......................................... 10

Figure ES.2: Share of Transit Region Change in Selected Commuting Mode Choice, Households without Vehicles and Workers Working at Home by Distance Band from LRT, BRT, SCT

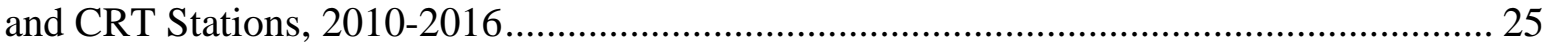

Figure ES.3: Illustration of the Association between Transit Station Proximity and Typical Regional Household Transportation Costs as a Percent of Regional Median Household Income.

Figure ES.4: The percent rent change from the mean between XBT station proximity and office, multifamily and retail rents per square foot .............................................................. 41

Figure 2.1: Illustration of Commercial Rents with Respect to Light Rail Transit Station Proximity to 2.00 Miles ......................................................................................... 72

Figure 2.2: Illustration of Commercial Rents with Respect to Bus Rapid Transit Station Proximity to 1.00 Mile 75

Figure 2.3: Illustration of Commercial Rents with Respect to Streetcar Station Proximity to 2.00 Miles 78

Figure 2.4: Illustration of Commercial Rents with Respect to Commuter Rail Transit Station Proximity to 2.00 Miles

Figure 5.1: The Portland Streetcar is credited with facilitating new residential development since its inauguration in 2001.

Figure 6.1: Share of Transit Region Change in Selected Commuting Mode Choice, Households without Vehicles and Workers Working at Home by Distance Band from Light Rail Stations, 2010-2016 188

Figure 6.2: Share of Transit Region Change in Selected Commuting Mode Choice, Households without Vehicles and Workers Working at Home by Distance Band from Bus Rapid Transit Stations, 2010-2016 190

Figure 6.3: Share of Transit Region Change in Selected Commuting Mode Choice, Households without Vehicles and Workers Working at Home by Distance Band from Streetcar Transit Stations, 2010-2016 192

Figure 7.1. Graphic representation of von Thunen’s bid-rent gradient. Source: Fujita (2012).. 199 Figure 7.2. Graphic depiction of Bid Rent Theory of Alonso (1964). 200

Figure 8.1: Positive Amenity $\left(\mathrm{R}^{\mathrm{a}}\right)$ and Negative Amenity $\left(\mathrm{R}^{\mathrm{n}}\right)$ influences of transition stations on proximate property values.

Figure 9.1: Illustration of the Association between Transit Station Proximity and Typical Regional Household Transportation Costs as a Percent of Regional Median Household Income, Light Rail Systems

Figure 9.2: Illustration of the Association between Transit Station Proximity and Typical Regional Household Transportation Costs as a Percent of Regional Median Household Income, Bus Rapid Transit Systems

Figure 9.3: Illustration of the Association between Transit Station Proximity and Typical Regional Household Transportation Costs as a Percent of Regional Median Household Income, Streetcar Transit Systems.

Figure 10.1: The percent rent change from the mean between XBT station proximity and office, multifamily and retail rents per square foot.... 271 


\section{EXCUTIVE SUMMARY}

Fixed route transit (FRT) systems have proliferated across the United States since 1980. Until then, commuter rail and heavy (third) rail transit were the mainstays of FRT systems serving older, larger cities of the Northeast and the Great Lakes. Fast forward to the early $21^{\text {st }}$ century and we see that most metropolitan areas of more than one million people, and many smaller ones, operate light rail transit (LRT—see Figure ES.1), streetcar transit (SCT—see Figure ES.2), bus rapid transit (BRT—see Figure ES.3) as well as commuter rail transit (CRT—see Figure ES.4) systems. The key purpose of these systems is to move people perhaps mostly to downtowns but also to secondary notes, medical centers, educational institutions, sporting and recreation venues, and so forth.

Policy makers and their planners often envision other objectives justifying FRT costs such as expanding economic development, making jobs more accessible to lower income workers and households, reduce congestion and its collateral outcomes such as air pollution, and improve the balance between where workers work and where people live. Exploring whether FRT systems achieve these outcomes is the purpose of this report for the National Institute of Transportation and Communities (NITC).

In this report, we explore various ways in which FRT systems and especially transit stations make a difference. Our central research question is this:

\section{Are there differences in development outcomes over time with respect to FRT station proximity and so these differences vary by type of FRT system?}

Our analysis is applied to all FRT systems noted in Table ES 1. However, some analyses may exclude some systems because of timing. For instance, while all systems are included in Chapter 2, which applies hedonic regression analysis to all systems using CoStar rent date for early 2018 - during which time all systems were operating, other analyses were limited to systems operating in earlier years.

We apply several statistical techniques to public domain and private, commercial databases to address the central question. This report is the product of work that begin in 2011 and remains ongoing. The report includes 11 chapters as well as a lengthy appendix that summarizes the nearly 200 systems studied in various ways. Here we summarize key findings of chapters 2 through 10 that report specific research efforts. In all cases our research presents associations, relationships, or links between FRT systems and development outcomes-we do not purport to demonstrate causal relationships, path dependencies, or other cause-and-effect outcomes.

This Executive Summary reviews key findings of the 10 research-based chapters. In concludes with a summary of key findings and recommendations. 


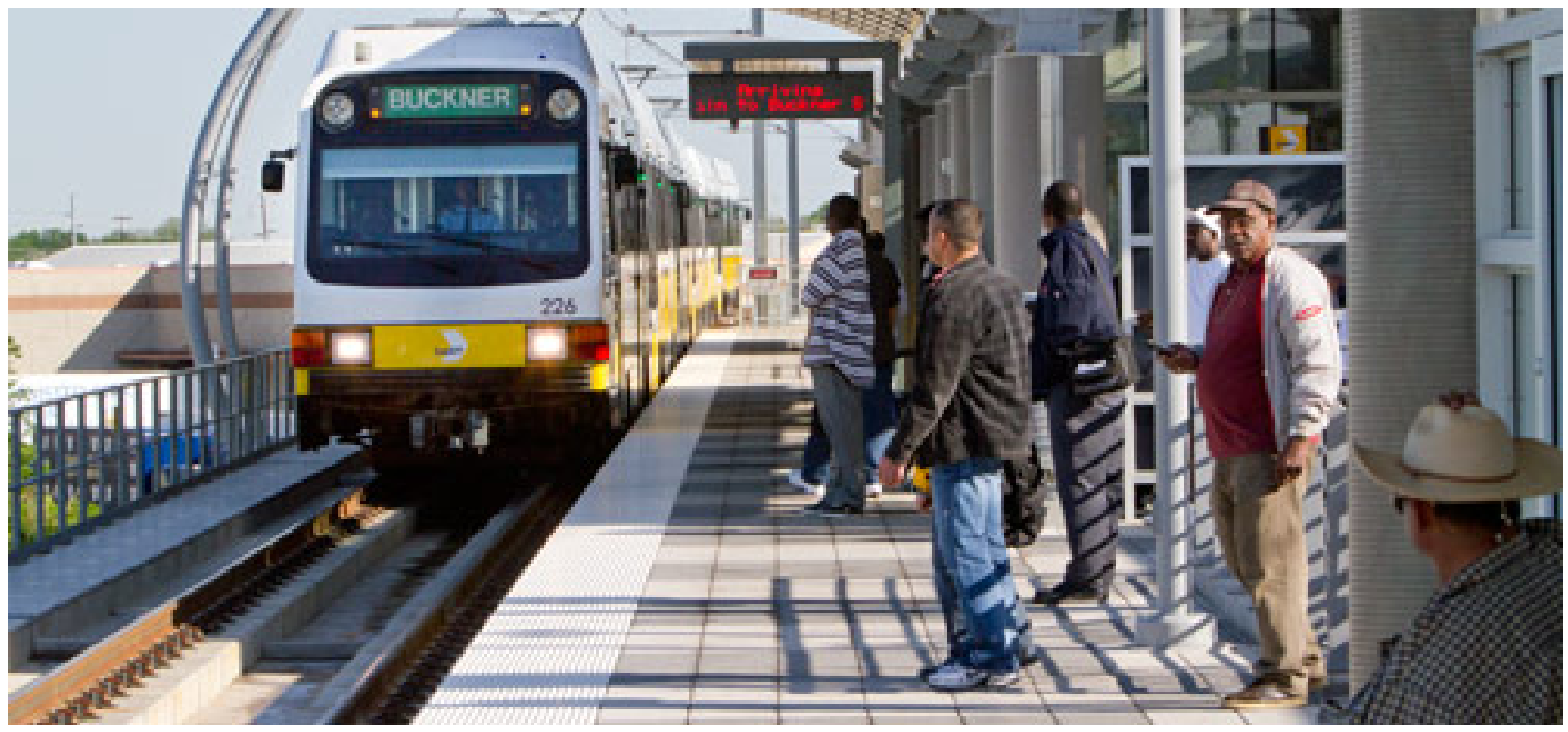

Figure ES.1: Dallas Area Rapid Transit light rail

Source: https://www.dart.org/images/darttrainatstation.jpg 


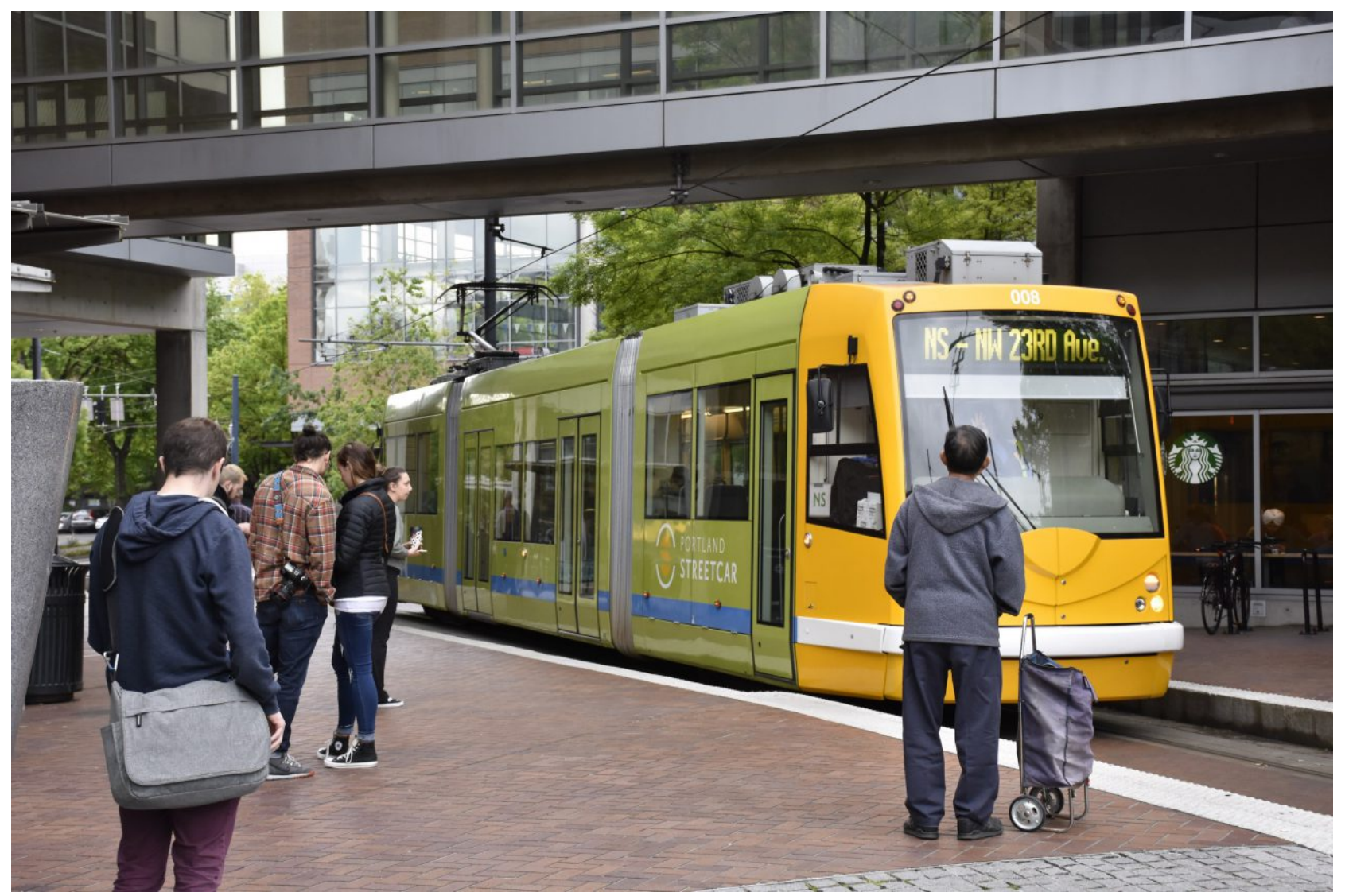

Figure ES.2: Portland, Oregon, streetcar

Source: https://portlandstreetcar.org/about-us/media/photos 


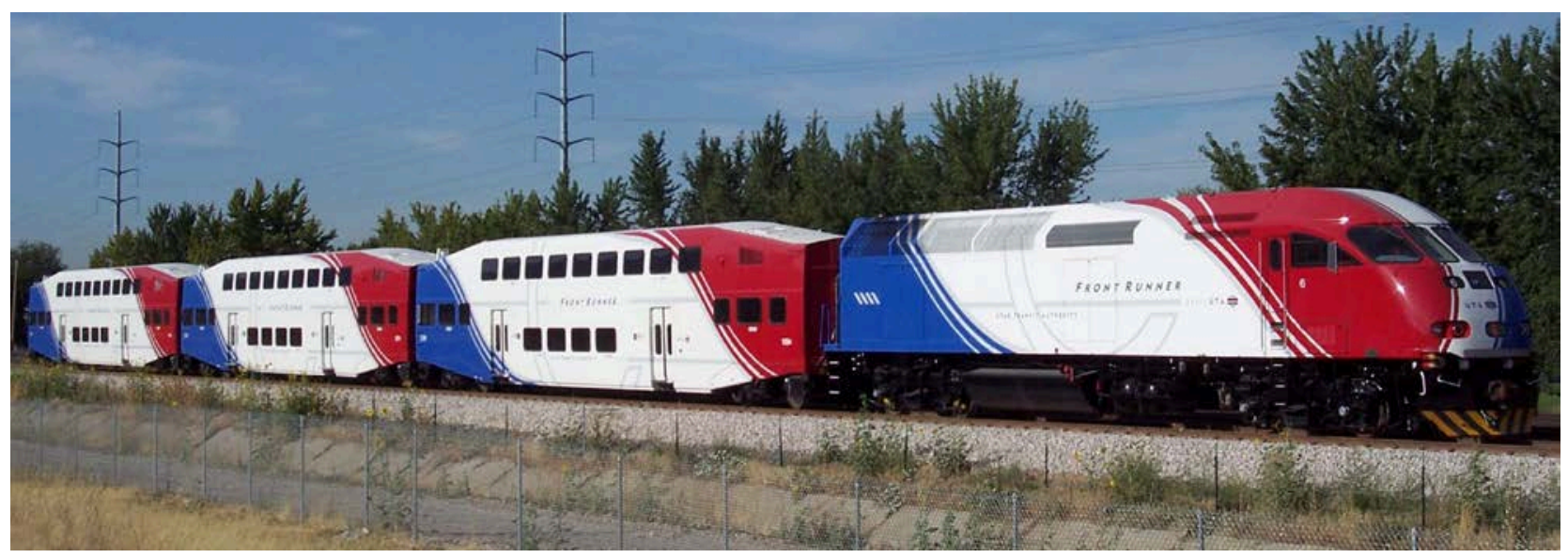

Figure ES.3: Utah Transit Authority Frontrunner commuter rail

Source: http://www.rideuta.com/uploads/commuterRailHighRes.jpg 


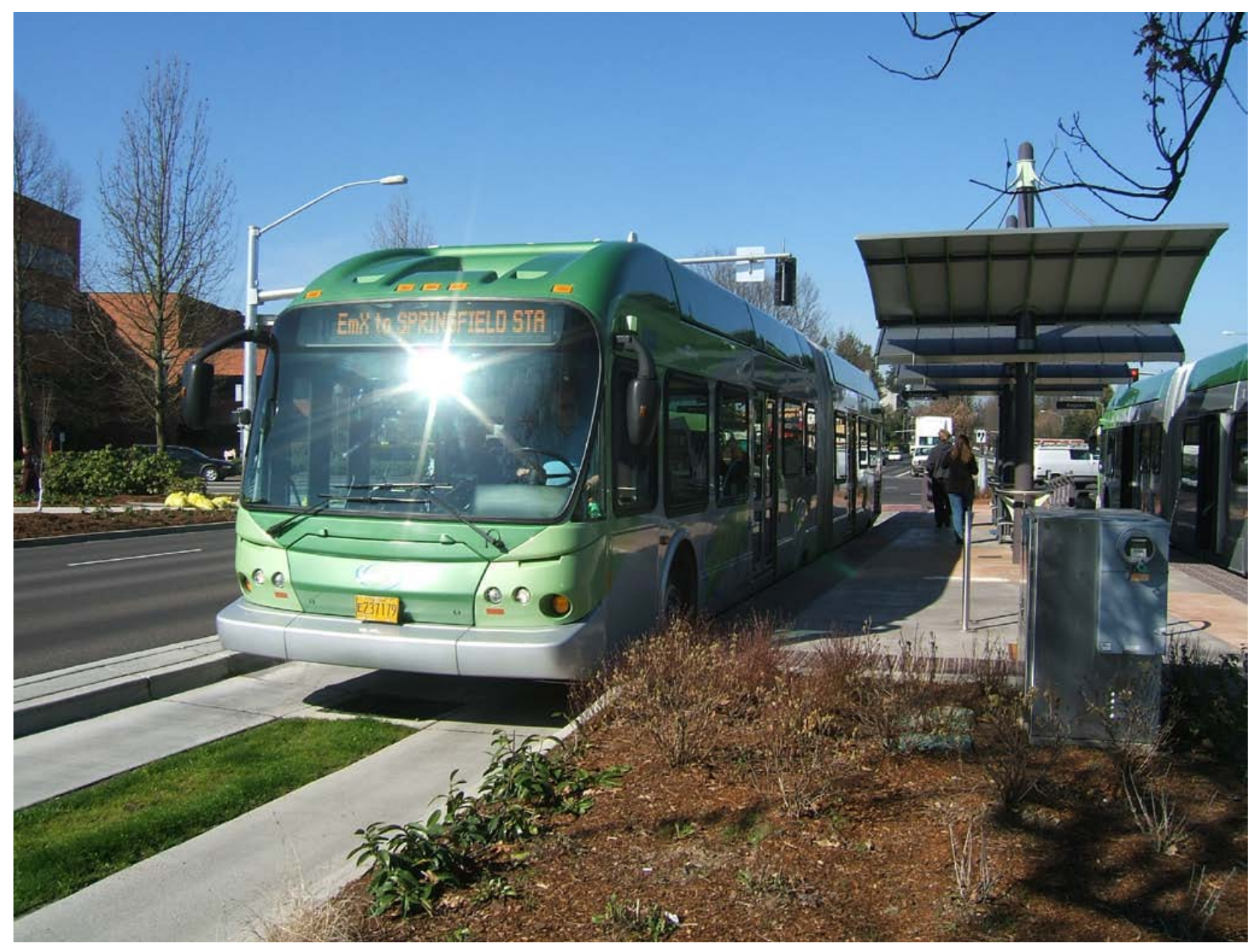

Figure ES.4: Lane County Transit Emerald Express bus rapid transit serving Eugene-Springfield, Oregon

Source: National Bus Rapid Transit Institute 
Table ES.1: Fixed Route Transit (FRT) Systems Studied

\begin{tabular}{ll|ll|lc|lc}
\hline Light Rail Transit & Year & Bus Rapid Transit & Year & Streetcar Transit & Year & $\begin{array}{l}\text { Commuter Rail } \\
\text { Transit }\end{array}$ \\
\hline Buffalo & & & & & Year \\
\hline Charlotte & 1984 & Cleveland & 2008 & Atlanta & 2014 & Albuquerque-Santa Fe & 2006 \\
\hline Cleveland & 2007 & Eugene-Springfield & 2007 & Cincinnati & 2016 & Austin \\
\hline Dallas & 1980 & Kansas City & 2005 & Dallas & 2015 & Dallas-Fort Worth & 1996 \\
\hline Denver & 1996 & Las Vegas & 2004 & Kansas City & 2016 & Miami Tri-Rail & 1989 \\
\hline Houston & 1994 & Nashville & 2009 & Little Rock & 2004 & Minneapolis \\
\hline Minneapolis-St. Paul & 2004 & Phoenix & 2009 & New Orleans & 2016 & Nashville \\
\hline Norfolk & 2004 & Pittsburgh & 1977 & Portland & 2001 & Orlando \\
\hline Phoenix & 2011 & Reno & 2010 & Salt Lake City & 2013 & Portland \\
\hline Pittsburgh & 2008 & Salt Lake City & 2008 & Seattle & 2007 & Salt Lake City \\
\hline Portland & 1984 & San Antonio & 2012 & Tacoma & 2003 & San Diego \\
\hline Sacramento & 1986 & San Diego & 2014 & Tampa & 2002 & San Jose-Stockton & 2009 \\
\hline Salt Lake City & 1987 & Seattle & 2010 & Tucson & 2014 & Seattle-Tacoma \\
\hline San Diego & 1999 & Stockton & 2007 & Washington, DC & 2016 & \\
\hline San Jose & 1981 & & & & \\
\hline Seattle & 1987 & & & & & \\
\hline St. Louis & 2003 & & & &
\end{tabular}

Source: Arthur C. Nelson and Robert Hibberd, University of Arizona. 


\section{Chapter 2-The Link between Transit Station Proximity and Commercial Real Estate Rents with Implications for Transit and Land Use Planning}

In this chapter, we present research into the link between FRT station proximity and commercial office, multifamily and retail rents with respect to LRT, BRT, SCT and CRT systems. Our research question is simply:

\section{Is there an association between commercial real estate rent (per square foot) and proximity to FGT stations holding other factors constant?}

Regression analysis is applied to CoStar rent data as well we data on structure characteristics, census data, and distances to downtown, the nearest freeway ramp, and transit station in units of one eighth (0.125) miles to two miles away. Table ES.2 provides a matrix of our findings while Figure ES.1 illustrates findings. There are many surprises.

For LRT stations, only the first (0.125 mile) distance band is statistically significant with respect to office properties which is inconsistent with numerous other studies. Results for multifamily and retail properties are consistent with expectations suggesting there is a multifamily rent premium up to 1.5 miles away from LRT stations and about 1.25 miles for retail activities. When running analysis of the 17 individual systems, we find that about a third have only ambiguous coefficients for distance bands relating to office properties while a third have mostly negative associations and the balance have the expected positive associations. We surmise that many LRT systems locate their stations in areas not conducive to the office market, and may also design them to reduce accessibility. This finding led us to add a chapter devoted to exploring location and design issues (Chapter 8).

We note that for BRT stations the innermost (0.125 mile) distance band has ambiguous outcomes for all three commercial types beyond which office has significant coefficients to 0.50 mile and retail having statistically significant coefficients to 0.375 mile. Multifamily is very different with the next ( 0.25 mile) distance band having a negative coefficient and then after a small distance having positive coefficients from about 0.50 to 1.00 mile. Regressions for 13 individual systems revealed widely varying outcomes with many systems having negative or ambiguous coefficients near BRT stations with usually modest distances with significant coefficients. We surmise that BRT station location and perhaps design does not generate rent premiums consistent with expectations for FRT systems.

Results for SCT systems are consistent with recent research. Generally, office premiums fall rapidly to less than 0.50 mile while strong retail premiums extend to about 0.875 mile. Multifamily premiums are higher than office though less than retail but extend two miles from SCT stations. Given the SCT systems serve mostly downtown or nearby areas, it is the urbanized of transit systems studied. We are impressed by the distance over which SCT systems have multifamily rent premiums. We surmise that though people may walk longer distances to access destinations in downtowns than other areas, there are also many more ways in which to access such destinations such as SCT stations including bicycles and feeder busses.

Another surprise are the rent premiums associated with CRT distance proximity. Positive coefficients for office extend to 0.875 mile while for multifamily they extend two miles. Such 
robust findings are inconsistent with the body of literature estimating the value of proximity to CRT stations. But those studies were limited to just a few individual systems. We surmise that people want to be close to CRT stations and will travel some distance to park-and-ride/kiss-andride lots, or feeder busses. That the retail rent premium extends only to the first ( 0.125 mile) distance band seems intuitively logical as CRT riders may wish to buy items very near the station for their journey.

Chapter 2 offers many surprises that help understand results from economic base and demographic analysis presented in chapters 3 through 7, and explorations of FRT station planning and design in Chapter 8. 
Table ES.2: Significant Distance Band Coefficients with Respect to LRT, BRT, SCT and CRT Station Proximity for Office, Multifamily and Retail Rents

\begin{tabular}{|c|c|c|c|c|c|c|c|c|c|c|c|c|}
\hline \multirow{2}{*}{$\begin{array}{l}\text { Distance } \\
\text { Band }\end{array}$} & \multicolumn{3}{|c|}{ Light Rail Transit } & \multicolumn{3}{|c|}{ Bus Rapid Transit } & \multicolumn{3}{|c|}{ Streetcar Transit } & \multicolumn{3}{|c|}{ Commuter Rail Transit } \\
\hline & Office & Multifamily & Retail & Office & Multifamily & Retail & Office & Multifamily & Retail & Office & Multifamily & Retail \\
\hline 0.125 & $1.70 \%$ & $4.80 \%$ & $8.30 \%$ & & & & $8.30 \%$ & $20.80 \%$ & $45.50 \%$ & $13.60 \%$ & $9.90 \%$ & $1.60 \%$ \\
\hline 0.250 & & $7.20 \%$ & $5.80 \%$ & $6.50 \%$ & $-2.50 \%$ & $14.00 \%$ & $14.30 \%$ & $21.50 \%$ & $21.50 \%$ & $16.10 \%$ & $5.30 \%$ & \\
\hline 0.375 & & $4.50 \%$ & $3.10 \%$ & $6.50 \%$ & & $8.50 \%$ & $9.10 \%$ & $18.40 \%$ & $20.50 \%$ & $16.90 \%$ & $4.60 \%$ & \\
\hline 0.500 & & $5.70 \%$ & $2.60 \%$ & $5.30 \%$ & $1.90 \%$ & & & $17.10 \%$ & $30.70 \%$ & $12.60 \%$ & $6.00 \%$ & \\
\hline 0.625 & & $5.00 \%$ & $3.60 \%$ & & $2.10 \%$ & & & $13.10 \%$ & $32.40 \%$ & $5.60 \%$ & $5.40 \%$ & \\
\hline 0.750 & & $6.10 \%$ & $4.10 \%$ & & $3.10 \%$ & & & $11.60 \%$ & $17.80 \%$ & $4.90 \%$ & $5.10 \%$ & \\
\hline 0.875 & & $4.60 \%$ & $4.90 \%$ & & $2.40 \%$ & & & $10.00 \%$ & & $3.60 \%$ & $2.00 \%$ & \\
\hline 1.000 & & $5.50 \%$ & $3.70 \%$ & & $3.60 \%$ & & & $9.90 \%$ & & & $5.10 \%$ & \\
\hline 1.125 & & $3.40 \%$ & $3.10 \%$ & & & & & $9.90 \%$ & & & $2.60 \%$ & \\
\hline 1.250 & & $2.80 \%$ & & & & & & $10.30 \%$ & & & $4.00 \%$ & \\
\hline 1.375 & & $2.10 \%$ & & & & & & $9.40 \%$ & & & $5.10 \%$ & \\
\hline 1.500 & & $1.50 \%$ & & & & & & $11.80 \%$ & & & $5.40 \%$ & \\
\hline 1.625 & & & & & & & & $11.20 \%$ & & & $6.40 \%$ & \\
\hline 1.750 & & & & & & & & $5.90 \%$ & & & $4.90 \%$ & \\
\hline 1.875 & & & & & & & & $9.70 \%$ & & & $6.50 \%$ & \\
\hline 2.000 & & & & & & & & $7.30 \%$ & & & $4.00 \%$ & \\
\hline
\end{tabular}

Source: Arthur C. Nelson and Robert Hibberd, University of Arizona.

Note: Coefficients are interpreted as the percent change in rent from mean rent for all cases associated with those cases located within respective distance bands. For instance, the SCT 0.125 mile distance band coefficient for multifamily properties indicates that those properties rent for $20.80 \%$ more per square foot than the mean for all multifamily properties (being 11,236 ) in the sample. 


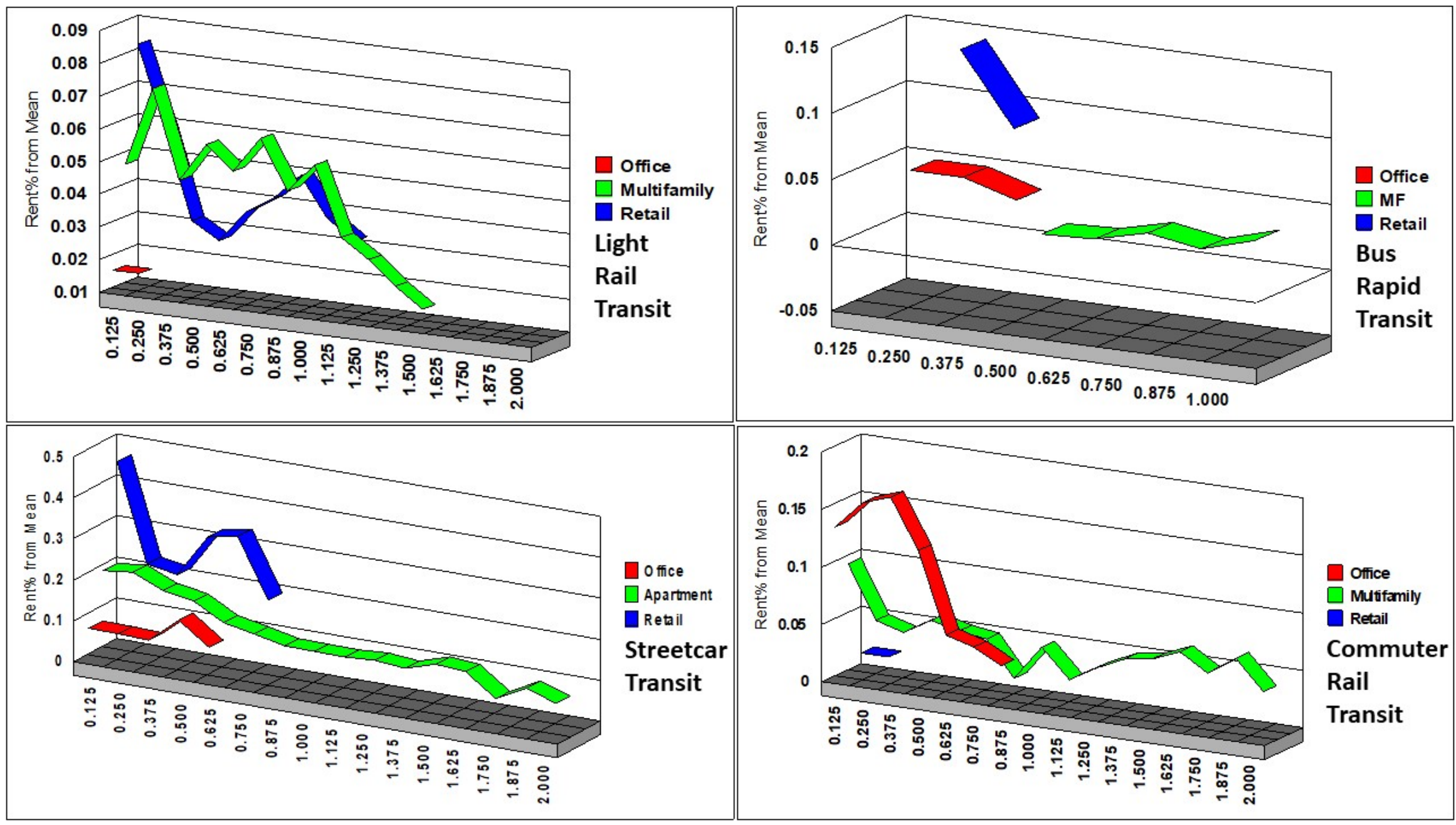

Figure ES.1: Significant Distance Band Coefficients with Respect to LRT, BRT, SCT and CRT Station Proximity for Office, Multifamily and Retail Rents

Source: Arthur C. Nelson and Robert Hibberd, University of Arizona. 


\section{Chapter 3-The Variation of Economic Development with Respect to Fixed Route Transit Station Proximity Before, During and After the Great Recession}

This chapter uses descriptive analysis to investigate the influence of FRT station proximity on the change in the distribution of total workers before the Great Recession (2004 through 2007), the years during and immediately following the Great Recession (2008 through 2011), and after the Great Recession (2012-2015) —all equal periods of time. (We measure workers instead of jobs; a person can have multiple jobs in multiple locations but a worker usually works at a specific location.). Our first research question is:

\section{Do FRT station areas capture proportionately more workers than their regions over time and are there variations by transit type and age of systems?}

For the most part, we find that total workers shifted away from FRT stations before the Great Recession, shifted toward them during the Great Recession, and continued to shift toward them since the Great Recession albeit at a slower pace. However, there is considerable variation based on the distance measures used, between systems and among economic sectors. These differences create a complex web of understanding how economic development—-measured as workers-is influenced by variations among transit systems, transit station proximity, and economic sectors.

Our analysis estimates outcomes within one-eighth (0.125) mile distance bands to one (1.00) mile from FRT stations. We compare outcomes to "Transit Regions" which is comprised of those counties within which FRT systems operate. For instance, Tucson's streetcar operates only within Pima County while Portland's light rail system operates in Clackamas, Multnomah and Washington counties - these are the Transit Regions (TR).

We also test the Nelson-Stoker-Hibberd Resilience Hypothesis. In 2018, Nelson, Stoker and Hibberd (see Chapter 3 for citation) advanced their Resilience Hypothesis. Conceptually, one outcome of such an economic shock as the Great Recession is to alter future development patterns toward locations that are near FRT stations to hedge against future economic shocks. We confirm this hypothesis

We find that during the early 2000s, many Transit Regions lost workers from FRT stations to 0.50 -mile outward, especially with respect to newer FRT systems. The Great Recession may have stopped the outward spread of workers but it also reduced growth so in many cases FRT station areas continued to lose workers though in many others the hemorrhaging had slowed, if not reversed thereby confirming the Nelson-Stoker-Hibberd Resilience Hypothesis. In some situations, especially among $1^{\text {st }}$ and $2^{\text {nd }}$ generation light rail systems (those launched before 2000), station areas gained workers. The post-recession period saw what we consider a reset in how the market responds to FRT station proximity. In most cases, workers increased in station areas, often reversing trends seen during the Great Recession if not before. In some cases, stations accounted for all a Transit Region's worker growth, further supporting the NelsonStoker-Hibberd Resilience Hypothesis.

We provide an overall perspective of the link between FRT station areas and change in Transit Region workers during the post-recession period in Table 3.15. We choose this period over others for three reasons. First, America is unlikely to see the kind of massive urban sprawl in the 
future as it saw during the early 2000s, even if suburbia still accounts for two-third or more of all new development. Second, the Great Recession—being the worst economic downturn in the US since the Great Depression-is unlikely to repeat. Third, it is the most recent period that may better reflect current and emerging market conditions than prior periods.

Two implications stand out. For one thing, the innermost (0.125-mile) distance bands for LRT, BRT and SCT stations absorbed large shares of the growth in workers during the period 20122015. On the other hand, LRT systems gained an even larger share of workers in the $0.25-0.50$ mile distance band. In contrast, the $0.25-0.50$ mile distance band did not perform for BRT (which was negative) or SCT systems. CRT systems performed less well but outcomes are not trivial; nearly $9 \%$ of the total share of new CRT Transit Region workers were attracted to areas within 0.50 mile of CRT transit stations.

This leads to certain interpretations:

- For LRT systems, the innermost (0.125-mile) distance band comprises just $0.3 \%$ of the Transit Region urban area (UA) (the current Census term for urbanized land) but accounted for $4.9 \%$ of the new workers, or a ratio of 14.0 times. Over one-half $(0.50)$ mile, LRT systems accounted for $17.7 \%$ of new Transit Regions' workers on only 3.5\% of the UA - a ratio of 5.0 times. For transit and land use planning purposes, it would seem prudent to facilitate worker growth within at least one-half (0.05) mile of LRT transit stations.

- BRT systems absorbed $18.8 \%$ of the new Transit Region workers on just $1.4 \%$ of the UA or a ratio of 13.9. However, there appears to be a substantial reduction in worker absorption beyond one-quarter $(0.25)$ mile. The area within one-quarter $(0.25)$ mile of BRT stations may be the economic development threshold for BRT and land use planning.

- Our analysis indicates that SCT systems absorbed 5.6\% of their Transit Regions' workers in the first (0.125-mile) distance band on just $0.2 \%$ of the Transit Region UA-a ratio of 30.3. However, absorption appears to peak after one-quarter $(0.25)$ mile were $8.1 \%$ of the Transit Regions' new workers located, on just $0.4 \%$ of the Transit Regions' UA or a ratio of 18.4. It appears for transit and land-use planning purposes that the first quarter (0.25) mile from SCT stations may generate the best results.

- As we implied in Chapter 2 and will note in late chapters, CRT systems may be underappreciated for their potential to accommodate new workers and people. In Table ES.3 we find that CRT stations attracted $2.6 \%$ of their Transit Regions' new workers on just $0.1 \%$ of the Transit Region UA, a ratio of 38.1. We also find substantial attractiveness to economic development to at least one-half (0.50) mile from CRT stations, which is our recommended area for transit and land use planning for economic development purposes.

One of these themes - that areas near transit stations absorb multiple times more workers than the Transit Region urban area—will recur in other chapters. 
Table ES.3: Post-Recession Share of Transit Region Worker Change by Distance Band and Ratio of Worker Share to Distance Band UA Share of Table ES.3: Post-Recession S
Transit Region Urban Area

\begin{tabular}{|c|c|c|c|c|c|c|c|c|c|c|c|c|}
\hline $\begin{array}{c}\text { Distance } \\
\text { Band, } \\
\text { Mile }\end{array}$ & $\begin{array}{c}\text { LRT } \\
\text { Distance } \\
\text { Band } \\
\text { Share of } \\
\text { Transit } \\
\text { Region } \\
\text { UA }\end{array}$ & $\begin{array}{c}\text { LRT-- } \\
\text { Share of } \\
\text { Regional } \\
\text { Worker } \\
\text { Change } \\
2012- \\
2015\end{array}$ & $\begin{array}{c}\text { LRT-- } \\
\text { Ratio of } \\
\text { Job } \\
\text { Change } \\
\text { to } \\
\text { Distance } \\
\text { Band } \\
\text { UA }\end{array}$ & $\begin{array}{c}\text { BRT } \\
\text { Distance } \\
\text { Band } \\
\text { Share of } \\
\text { Transit } \\
\text { Region } \\
\text { UA }\end{array}$ & $\begin{array}{c}\text { BRT-- } \\
\text { Share of } \\
\text { Regional } \\
\text { Worker } \\
\text { Change } \\
2012- \\
2015\end{array}$ & $\begin{array}{c}\text { BRT-- } \\
\text { Ratio of } \\
\text { Job } \\
\text { Change } \\
\text { to } \\
\text { Distance } \\
\text { Band } \\
\text { UA }\end{array}$ & $\begin{array}{c}\text { SCT } \\
\text { Distance } \\
\text { Band } \\
\text { Share of } \\
\text { Transit } \\
\text { Region } \\
\text { UA }\end{array}$ & $\begin{array}{c}\text { SCT-- } \\
\text { Share of } \\
\text { Regional } \\
\text { Worker } \\
\text { Change } \\
2012- \\
2015\end{array}$ & $\begin{array}{c}\text { SCT-- } \\
\text { Ratio of } \\
\text { Job } \\
\text { Change } \\
\text { to } \\
\text { Distance } \\
\text { Band } \\
\text { UA }\end{array}$ & $\begin{array}{c}\text { CRT } \\
\text { Distance } \\
\text { Band } \\
\text { Share of } \\
\text { Transit } \\
\text { Region } \\
\text { UA }\end{array}$ & $\begin{array}{c}\text { CRT-- } \\
\text { Share of } \\
\text { Regional } \\
\text { Worker } \\
\text { Change } \\
2012- \\
2015\end{array}$ & $\begin{array}{c}\text { CRT-- } \\
\text { Ratio of } \\
\text { Job } \\
\text { Change } \\
\text { to } \\
\text { Distance } \\
\text { Band } \\
\text { UA }\end{array}$ \\
\hline $\begin{array}{l}0.00- \\
0.125 \\
\end{array}$ & $0.3 \%$ & $4.9 \%$ & 14.0 & $1.4 \%$ & $18.8 \%$ & 13.9 & $0.2 \%$ & $5.6 \%$ & 30.3 & $0.1 \%$ & $2.6 \%$ & 38.1 \\
\hline $\begin{array}{c}0.125- \\
0.25 \\
\end{array}$ & $0.9 \%$ & $3.6 \%$ & 4.2 & $2.1 \%$ & $2.0 \%$ & 1.0 & $0.3 \%$ & $2.5 \%$ & 9.8 & $0.2 \%$ & $1.7 \%$ & 8.4 \\
\hline $\begin{array}{c}0.00- \\
0.25 \\
\end{array}$ & $1.2 \%$ & $8.5 \%$ & 7.1 & $3.4 \%$ & $20.8 \%$ & 6.1 & $0.4 \%$ & $8.1 \%$ & 18.4 & $0.3 \%$ & $4.4 \%$ & 16.0 \\
\hline $\begin{array}{c}0.25- \\
0.50 \\
\end{array}$ & $2.4 \%$ & $9.2 \%$ & 3.9 & $4.0 \%$ & $-3.9 \%$ & -1.0 & $0.5 \%$ & $1.2 \%$ & 2.2 & $0.8 \%$ & $4.4 \%$ & 5.6 \\
\hline $\begin{array}{c}0.00- \\
0.50\end{array}$ & $3.5 \%$ & $17.7 \%$ & 5.0 & $7.6 \%$ & $16.9 \%$ & 2.2 & $1.1 \%$ & $9.3 \%$ & 8.3 & $1.1 \%$ & $8.8 \%$ & 8.3 \\
\hline
\end{tabular}

Source: Arthur C. Nelson and Robert Hibberd, University of Arizona. 


\section{Chapter 4-The Link between Transit Station Proximity and Change in Workers by Economic Groups and Wages since the Great Recession}

This chapter does two things:

First, it explores the distribution of the change of workers by economic groups since the Great Recession, 2011-2015, and provides insights for transit and land use planning

Second, it explores changes in the distribution of upper-, middle- and lower-wage workers during the same period.

We use the Longitudinal Employment-Household Dynamics (LEHD) database because it provides information we need to address this research question:

\section{Is there a link between transit station proximity and change in workers by economic group since the Great Recession?}

Overall, we find that firms with workers in the knowledge, office, and arts-entertainmentrecreation economic groups are attracted to locations near transit stations. Firms with workers in the manufacturing and light manufacturing economic groups tend to locate some distance away from transit stations perhaps because of their need for large parcels of land built at low intensities. Firms in the retail-lodging-food service, education and health care economic groups appear to be trending toward locations near transit stations. We also find that between 2011 and 2015, workers in upper-wage economic groups dominated the change in worker wages near transit stations followed by workers in lower wage economic groups. Firms with middle-wage workers may be displaced from locations near transit stations. Insights from each of the two analyses are offered.

This database provides information to the census block level for workers in all 20 of the North American Industrial Classification System's (NAICS) 2-digit economic sectors. We exclude natural resource-based sectors (reporting workers in agriculture, forestry, fishing and mining). The reason is that for the most part, they do not occupy structures. We also exclude workers in the construction sector since they do not occupy structures permanently. We group the remaining economic sectors into eight economic groups roughly reflecting comparable land use needs. For instance, office location and design for instance is different from education, manufacturing and other economic groups. The economic groups used in our analysis are shown in Table ES.4

In this summary, we report location trends for economic groups with respect to LRT, BRT, SCT and CRT station proximity, respectively. What we calculate are the Location Quotients for 2015 divided by the Location Quotients for 2011 to identify those economic groups. (See Chapter 4 for review of location quotients.) Based on findings in Chapter 3, we focus on the first one-half (0.50) mile from FRT stations. Results are reported in Table ES.5. The highlighted cells are interpreted as follows:

Cells with white bold figures against black backgrounds have LQs or 2015/2011 LQ ratios equal to or greater than 1.0 indicating either that an economic group concentrates within one-half (0.50) mile of transit stations (upper part of the table) or trended toward greater concentration from 2011 to 2015. Cells with black bold figures against gray 
backgrounds indicate that an economic group's performance in one cell is adjacent to others where figures are greater than 1.0 and as such suggest potential spillovers from the cell with the higher figure into the lower one where the lower one is also substantially close to 1.0 in its own right.

Table ES.4: Combinations of NAICS Sectors into Economic Groups for Analysis

\begin{tabular}{|c|c|}
\hline NAICS Code & NAICS Sector Title and Economic Group Name \\
\hline & Industrial \\
\hline $31-33$ & Manufacturing \\
\hline \multirow[t]{2}{*}{22} & Utilities \\
\hline & Light Industrial \\
\hline 42 & Wholesale Trade \\
\hline \multirow[t]{2}{*}{$48-49$} & Transportation and Warehousing \\
\hline & Retail-Lodging-Food (“Retail-Lodging”) \\
\hline $44-45$ & Retail Trade \\
\hline \multirow[t]{2}{*}{72} & Accommodation and Food Services \\
\hline & Knowledge \\
\hline 51 & Information \\
\hline \multirow[t]{2}{*}{54} & Professional, Scientific, and Technical Services \\
\hline & Office \\
\hline 52 & Finance and Insurance \\
\hline 53 & Real Estate and Rental and Leasing \\
\hline 55 & Management of Companies and Enterprises \\
\hline 56 & Administrative and Support, Waste Management, Remediation \\
\hline 81 & Other Services (except Public Administration) \\
\hline \multirow[t]{2}{*}{92} & Public Administration \\
\hline & Education \\
\hline \multirow[t]{2}{*}{61} & Educational Services \\
\hline & Health \\
\hline \multirow[t]{2}{*}{62} & Health Care and Social Assistance \\
\hline & Arts-Entertainment-Recreation (“Arts-Ent-Rec”) \\
\hline 71 & Arts, Entertainment, and Recreation \\
\hline
\end{tabular}

Source: Adapted from the North American Industrial Classification System by Arthur C. Nelson and Robert Hibberd, University of Arizona.

Note: Phrases in quotations and italics labels for the respective economic groups. 
Table ES.5: Economic Concentration Trend by Distance Band from FRT Stations, 2011 to 2015

\begin{tabular}{|c|c|c|c|c|c|c|c|c|}
\hline & \multicolumn{8}{|c|}{ Light Rail Transit LQ Trend 2011-2015 [2015LQ / 2011LQ] } \\
\hline $\begin{array}{l}\text { Distance Band, } \\
\text { Economic Group }\end{array}$ & 0.125 & 0.25 & 0.375 & 0.5 & 0.625 & 0.75 & 0.875 & 1 \\
\hline Manufacturing & 0.99 & 0.87 & 1.03 & 0.98 & 0.92 & 1.04 & 1.03 & 0.92 \\
\hline Light Industrial & 0.92 & 0.9 & 0.95 & 0.86 & 1.03 & 0.97 & 1.02 & 1.14 \\
\hline Retail-Lodging & 1.04 & 1.06 & 1 & 1.17 & 1 & 1.02 & 1 & 1.14 \\
\hline Knowledge & 1.11 & 0.93 & 1.06 & 1.08 & 0.98 & 0.98 & 1.2 & 1.07 \\
\hline Office & 0.94 & 1.07 & 0.95 & 1.1 & 1.01 & 0.95 & 1.06 & 0.86 \\
\hline Education & 1.02 & 0.87 & 1.04 & 0.6 & 1.16 & 0.94 & 0.98 & 0.88 \\
\hline Health & 1.09 & 1.01 & 1 & 0.9 & 0.91 & 1.15 & 0.84 & 1.06 \\
\hline Arts-Ent-Rec & 0.98 & 1.12 & 1.05 & 1.05 & 1.2 & 0.97 & 1.05 & 1.41 \\
\hline & \multicolumn{8}{|c|}{ Bus Rapid Transit LQ Trend 2011-2015 [2015LQ / 2011LQ] } \\
\hline $\begin{array}{l}\text { Distance Band, } \\
\text { Economic Group }\end{array}$ & 0.125 & 0.25 & 0.375 & 0.5 & 0.625 & 0.75 & 0.875 & 1 \\
\hline Manufacturing & 1 & 1.12 & 0.8 & 0.99 & 0.82 & 0.96 & 1.08 & 0.95 \\
\hline Light Industrial & 1.05 & 0.74 & 1.11 & 0.94 & 1.05 & 1.06 & 1.11 & 1.11 \\
\hline Retail-Lodging & 1.01 & 1.05 & 1.05 & 1.12 & 1 & 0.92 & 0.95 & 1.11 \\
\hline Knowledge & 1 & 1.01 & 1.08 & 1.09 & 0.88 & 1.05 & 1.06 & 1.06 \\
\hline Office & 0.98 & 1 & 0.88 & 0.95 & 0.9 & 1 & 0.91 & 0.98 \\
\hline Education & 1.02 & 1 & 1.11 & 0.93 & 1.38 & 1.11 & 1.08 & 0.83 \\
\hline Health & 0.97 & 0.99 & 1.02 & 0.85 & 1.09 & 1.02 & 1.04 & 0.92 \\
\hline Arts-Ent-Rec & 1.02 & 1.02 & 1.06 & 1 & 1.02 & 0.73 & 0.94 & 0.99 \\
\hline & \multicolumn{8}{|c|}{ Streetcar Transit LQ Trend 2011-2015 [2015LQ / 2011LQ] } \\
\hline $\begin{array}{l}\text { Distance Band, } \\
\text { Economic Group }\end{array}$ & 0.125 & 0.25 & 0.375 & 0.5 & 0.625 & 0.75 & 0.875 & 1 \\
\hline Manufacturing & 0.98 & 0.81 & 1.25 & 0.89 & 1.53 & 0.84 & 1.04 & 2.23 \\
\hline Light Industrial & 1.18 & 0.87 & 1.07 & 0.86 & 1.17 & 0.99 & 1.03 & 1.25 \\
\hline Retail-Lodge & 0.94 & 1.17 & 1.53 & 0.97 & 1.14 & 0.93 & 0.99 & 1.25 \\
\hline Knowledge & 1.08 & 1 & 1.23 & 0.88 & 1.14 & 0.64 & 1.06 & 1.15 \\
\hline Office & 1.02 & 0.94 & 0.75 & 0.92 & 1.26 & 1.42 & 1.13 & 0.59 \\
\hline Education & 0.95 & 1.12 & 0.88 & 2.05 & 0.53 & 0.71 & 0.9 & 1.01 \\
\hline Health & 0.83 & 1.1 & 1.23 & 0.97 & 1.06 & 0.88 & 0.75 & 1.15 \\
\hline Arts-Ent-Rec & 1.15 & 1.15 & 1.18 & 0.99 & 1.41 & 0.78 & 1.59 & 1.23 \\
\hline
\end{tabular}


Table ES.5: Economic Concentration Trend by Distance Band from FRT Stations, 2011 to 2015--continued

\begin{tabular}{l|c|c|c|c|c|c|c|c}
\hline & \multicolumn{7}{|c}{ LQ Trend 2011-2015 [2015LQ / 2011LQ] } \\
\hline $\begin{array}{l}\text { Distance Band, } \\
\text { Economic Group }\end{array}$ & $\mathbf{0 . 1 2 5}$ & $\mathbf{0 . 2 5}$ & $\mathbf{0 . 3 7 5}$ & $\mathbf{0 . 5}$ & $\mathbf{0 . 6 2 5}$ & $\mathbf{0 . 7 5}$ & $\mathbf{0 . 8 7 5}$ & $\mathbf{1}$ \\
\hline Manufacturing & $\mathbf{1 . 0 7}$ & $\mathbf{1 . 1}$ & $\mathbf{1 . 0 6}$ & 0.73 & 0.98 & 0.95 & 0.93 & 0.89 \\
\hline Light Industrial & $\mathbf{1 . 0 9}$ & $\mathbf{0 . 9 4}$ & $\mathbf{0 . 9 2}$ & $\mathbf{1 . 0 1}$ & 0.9 & 0.94 & 0.99 & 0.99 \\
\hline Retail-Lodging & $\mathbf{1}$ & $\mathbf{1 . 0 7}$ & $\mathbf{0 . 9 1}$ & $\mathbf{0 . 9 2}$ & 0.97 & 1.13 & 1.06 & 0.99 \\
\hline Knowledge & $\mathbf{0 . 9 6}$ & $\mathbf{0 . 9 9}$ & $\mathbf{1 . 2 3}$ & $\mathbf{1 . 0 9}$ & 1 & 1.13 & 1.01 & 1.08 \\
\hline Office & $\mathbf{1 . 0 3}$ & $\mathbf{0 . 8 6}$ & $\mathbf{0 . 9 9}$ & $\mathbf{1 . 0 6}$ & 0.79 & 0.84 & 0.96 & 1.03 \\
\hline Education & $\mathbf{0 . 9}$ & $\mathbf{1 . 1 3}$ & $\mathbf{0 . 9 1}$ & $\mathbf{1 . 2 2}$ & 3.2 & 0.96 & 0.99 & 1 \\
\hline Health & $\mathbf{0 . 9 5}$ & $\mathbf{1 . 2 4}$ & $\mathbf{0 . 9 5}$ & $\mathbf{1 . 0 3}$ & 1.07 & 1.04 & 1.04 & 0.88 \\
\hline Arts-Ent-Rec & $\mathbf{1 . 4 5}$ & $\mathbf{1 . 0 2}$ & $\mathbf{1 . 1 7}$ & $\mathbf{0 . 8 1}$ & 1.44 & 1.16 & 0.88 & 1.26 \\
\hline
\end{tabular}

Source: Arthur C. Nelson and Robert Hibberd, University of Arizona. 
For each FRT system, we find the following economic groups appear to cluster with the first 0.50 mile of transit stations.

LRT

Retail-Lodging-Food Service

Knowledge

Office

Education

Health

Arts-Entertainment-Recreation

\section{BRT}

Manufacturing

Light Industrial

Retail-Lodging-Food Service

Knowledge

Office

Education

Health

Arts-Entertainment-Recreation

\section{SCT}

Light Industrial

Retail-Lodging-Food Service

Knowledge

Office

Education

Health

Arts-Entertainment-Recreation

\section{CRT}

Manufacturing

Light Industrial

Retail-Lodging-Food Service

Knowledge

Office

Education

Health

Arts-Entertainment-Recreation 
These targets align with upper-, middle- and lower-wage groups which was the second part of the analysis in Chapter 4. Table ES.6 combines economic groups into these wage groups, allowing economic development analysts to match recommended target economic groups with respect to transit station distance with corresponding wage groups.

Based on the analysis presented in Chapter 4, we surmise that going forward from the Great Recession:

- LRT stations may gain share in upper wage workers but lose share among middle and lower wage workers especially in the 0.50 -mile distance band perhaps because people and housing are displacing workers from the innermost ( 0.25 mile) distance band;

- BRT stations do not seem poised to gain share in workers among any of the wage groups in the innermost ( 0.25 mile) distance band but may gain share of workers among the upper and middle wage categories (see Chapters 2 and 3 for possible reasons);

- SCT stations may be poised to gain share of regional worker change among upper and lower wage workers also in just the innermost ( 0.25 mile) distance but lose share among middle wage workers in that band, and lose regional share of worker change among all wage categories beyond; and

- CRT stations appear to be poised to gain regional share of workers among all wage categories in the innermost ( 0.25 mile) distance band though perhaps only upper wage workers in the next ( 0.50 mile) distance band.

The link between transit station proximity and changes in the regional share of people and housing, and commuting patterns is addressed in Chapters 5 and 6 while the link between transit station proximity on workers-housing balance, and workers-labor force balance over time is addressed in Chapter 7. 
Table ES.6: Allocation of Workers by Lower-, Middle- and Upper-Wage Category

\begin{tabular}{|c|c|c|c|c|}
\hline NAICS & Description & $\begin{array}{c}\text { Mean Annual } \\
\text { Wages, } 2013\end{array}$ & $\begin{array}{c}\text { Wage } \\
\text { Category }\end{array}$ & $\begin{array}{l}\text { Share of } \\
\text { Workers }\end{array}$ \\
\hline 44 & Retail Trade & $\$ 25,779$ & Lower & \\
\hline 56 & Administrative, Support, Waste Mgmt., Remediation & $\$ 35,931$ & Lower & \\
\hline 61 & Educational Services & $\$ 35,427$ & Lower & \\
\hline 71 & Arts, Entertainment and Recreation & $\$ 32,188$ & Lower & \\
\hline 72 & Accommodation and Food Services & $\$ 17,453$ & Lower & \\
\hline \multirow[t]{2}{*}{81} & Other Services (except Public Administration) & $\$ 29,021$ & Lower & \\
\hline & \multicolumn{2}{|l|}{ Weighted Mean Wages and National Share of Workers } & $\sim \$ 30,000$ & $\sim 33 \%$ \\
\hline 48 & Transportation and Warehousing & $\$ 45,171$ & Middle & \\
\hline 53 & Real Estate and Rental and Leasing & $\$ 46,813$ & Middle & \\
\hline 62 & Health Care and Social Assistance & $\$ 44,751$ & Middle & \\
\hline \multirow[t]{2}{*}{92} & Public Administration & $\$ 51,340$ & Middle & \\
\hline & \multicolumn{2}{|l|}{ Weighted Mean Wages and National Share of Workers } & $\sim \$ 50,000$ & $\sim 33 \%$ \\
\hline 22 & Utilities & $\$ 94,239$ & Upper & \\
\hline 31 & Manufacturing & $\$ 54,258$ & Upper & \\
\hline 42 & Wholesale Trade & $\$ 65,385$ & Upper & \\
\hline 51 & Information & $\$ 83,677$ & Upper & \\
\hline 52 & Finance and Insurance & $\$ 88,677$ & Upper & \\
\hline 54 & Professional, Scientific and Technical Services & $\$ 75,890$ & Upper & \\
\hline \multirow[t]{2}{*}{55} & Management of Companies and Enterprises & $\$ 105,138$ & Upper & \\
\hline & \multicolumn{2}{|l|}{ Weighted Mean Wages and National Share of Workers } & $\sim \$ 70,000$ & $34 \%$ \\
\hline
\end{tabular}

Source: Adapted from County Business Patterns, 2013 by Arthur C. Nelson and Robert Hibberd, University of Arizona. 


\section{Chapter 5-The Link between Transit Stations and People and Housing Before and After the Great Recession}

This chapter reports what may be the first effort to weave otherwise disparate transit planning objectives into an overall assessment of the extent to which FRT systems perform as desired over time. The research question is:

\section{Relative to the counties within which transit systems operate ("transit counties"), are there shifts in the regional share of people and housing over time with respect to $F R T$ station proximity, particularly with respect to change in:}

\section{Population by race,}

\section{Households by children present,}

\section{Householder age and type, and}

\section{Housing by tenure?}

Specifically, this chapter applies economic base analysis to more than 40 light rail transit (LRT), bus rapid transit (BRT), streetcar transit (SCT), and commuter rail transit (CRT) systems operating in more than 30 metropolitan areas to estimate shifts in the share of:

- $\quad$ People by minority status;

- Households by type and householder age; and

- Housing by tenure (owner/renter).

The analysis estimates outcomes with respect to one-eighth (0.125), one-quarter ( 0.25$)$, one-half (0.50), three-quarters (0.75) and one (1.00) mile buffers of FRT stations between 2000 and 2009 and recovery from 2010 to 2016.

Overall, we find positive shifts in the share of regional population and household change mostly favoring locations closest to FRT stations though positive effects are seen in all the distance bands. This is a remarkable finding, however, considering the land area around stations increases as distances from them increase, suggesting that FRT stations have a kind of gravitational attraction on people and housing. As suggested in Chapters 2 and 3, people may be attracted to station areas to such an extent that they are displacing jobs to locations farther way from stations. But there are nuances:

- While there is a popular perception that young people/households would be attracted to areas near transit stations we find that this is not necessarily the case. In terms of the share of such households, transit stations do not perform well and often have a negative link with respect to station proximity.

- In contrast, it is the group of householders between the age of 25 and 44 that seem to be attracted more to FRT stations. 
- Older households (ages 45 to 65 and 65 and older) seem especially attracted to areas near light rail stations, more so than younger ones.

- With few exceptions, households without children and, to a lesser extent, single parent households are attracted to locations near FRT stations.

- Areas near FRT stations tend to attract a higher share of their transit region's share rental demand, and a lower share of owner demand.

- While there is a positive link between changes in the share of regional population and household growth to about 0.50 mile from LRT stations - perhaps up to 1.00 mile- that link appears limited to just the innermost (0.125-mile) distance band from BRT, SCT and CRT stations. Yet we know from commercial rent analysis reported in Chapter 2 that the multifamily market pays a premium for proximity to these transit systems to 1.00 mile and in the case of SCT and CRT perhaps up to 2.00 miles away.

We surmise that there are opportunities to improve the ability of FRT stations to accommodate the regional demand for certain types of households who wish to live near them though not necessarily very near them such as in the first 0.125 -mile. We came to the same supposition in Chapter 3. In Chapter 6, we present research on the link between FRT station proximity and commuting mode choicer. 


\section{Chapter 6-The Link between Transit Station Proximity and Mode Choice to Work, Working at Home, and Vehicle Ownership}

One theorized benefit of proximity to such fixed route transit (FRT) systems is that residents will choose modes other than driving alone or carpooling to get to work. To the extent that FRT station areas themselves are also work destinations, people living near stations may also walk or bike to work. Moreover, proximity to transit enables those who work from home to access nonwork destinations via transit or walking and biking if those destinations are near transit stations. However, there is no literature that establishes the link between (a) FRT station proximity and mode choice to work, or (b) an increase in share of people working at home to choose locations near transit stations. Chapter 6 helps close this gap in research. It also provides insights for transit and land use planning. The following research question guides research reported in this chapter:

\section{Relative to the counties within which transit systems operate ("transit counties"), are there shifts in the regional share of:}

\section{Commuting mode choice with respect to FRT station proximity, particularly with respect to change in:}

\section{Driving alone and carpooling,}

\section{Transit, and}

\section{Walking and biking to work?}

Workers working at home and transit station proximity?

\section{Household vehicle ownership?}

Shift-share analysis is used to estimate the shift in the share of these outcomes from the end of the Great Recession (2010) into full recovery (2016), using American Community Survey data. Trends are illustrated in Figure ES.2.

For LRT, BRT and SCT systems, there appears to be a consistent pattern. The use of transit, walking or biking to work falls as transit station proximity increases, though there is a modest increase between the 0.75 - to 1.00-mile distance band. Likewise, the share of households without vehicles also decreases. The share of workers working at home is less pronounced though following the same overall pattern.

Outcomes for CRT are quite different. Generally, the share of workers using transit-walkingbiking commuting, household vehicle ownership and workers working at home fall over the first two distance bands, to about 0.25-mile, then increase to about the 0.75 -mile distance band before leveling off. We surmise the reason is that CRT service is not as frequent as the other modes.

Although the driving alone/carpool commute remains the dominate mode the change in share of commuters using other modes, especially with respect to transit station proximity is not trivial and appears to be increasing modestly. As we noted in Chapters 2, 3 and 5, local efforts to meet apparently unmet market demand for jobs and housing beyond the innermost (0.125-mile) 
distance band to the 0.50 -mile if not 1.00-mile distance bands may increase regional share of workers engaging in other than the driving along/carpooling mode to work. 


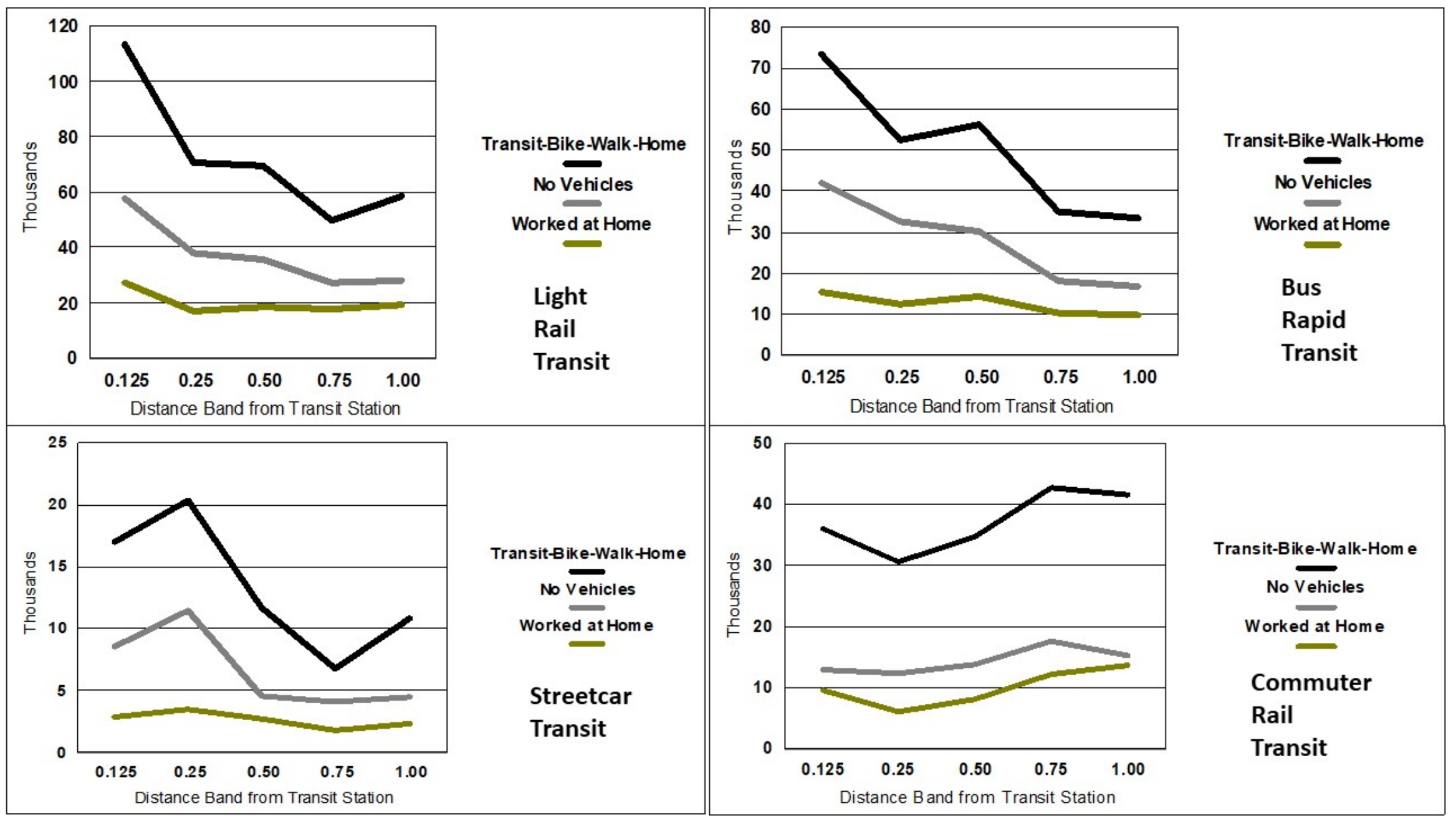

Figure ES.2: Share of Transit Region Change in Selected Commuting Mode Choice, Households without Vehicles and Workers Working at Home by Distance Band from LRT, BRT, SCT and CRT Stations, 2010-2016 


\section{Chapter 7-The Link between Jobs-Worker Balance by Income and Economic Group with Respect to Transit Station Proximity}

This chapter renews the assertion that increasing the balance of workplaces and residences near Fixed-Route Transit (FRT) stations by transit mode, segmented into wage and job sector categories provides multiple public and private benefits. Increasing the relative level of balance has been used by some planners to improve agglomeration economies and job accessibility and reduce segregation, emissions, freeway congestion and vehicle-miles traveled (VMT) in a region.

A relative balance of employment and workers' residences in a given neighborhood is missing in urban areas suffering from the spatial mismatch problem, in which segregated minority populations are spatially separated from their jobs, precipitating long commutes that in most cases require automobile ownership as a prerequisite to access. This presents some members of these communities with financial hardship. As auto-induced sprawl accelerated in the midtwentieth century, jobs followed housing beyond the urban core. The dispersed nature of land uses in suburbia virtually guaranteed an imbalance between jobs and housing. A lack of balance is therefore a ubiquitous feature across U.S. metropolitan areas.

While U.S. cities generally exhibit imbalance in overall jobs-worker ratios, they are particularly out of balance for lower-income households, as attested in the spatial mismatch literature. Evidence shows that areas balanced in terms of raw numbers of jobs and housing units can still require various income groups to commute elsewhere for their jobs.

This chapter reports on research guided by the following question:

\section{Do FRT system neighborhoods improve in employment-worker balance across the study years? Which income groups see the greatest improvements?}

The chapter evaluates the following categories of employment and worker residences: 1) overall, 2) upper, middle, or lower-wage workers at work per those at their residences, and 3) workers by job sector category at work per those at their residences. The analysis is based on light rail transit (LRT), bus rapid transit (BRT), streetcar transit (SCT) and commuter rail transit (CRT) systems noted by era in which operations commenced in Table ES.7. Chapter 7 presents results for equally spaced years from the pre-recession (2007), into the Great Recession (2011) and to fully recovery in post-recession (2015) periods,

We find that overall change has been towards residences and away from employment, but at a small magnitude of change. The magnitude varies in significant ways, however, per wage and job sector group, by generation of the transit system (i.e., when the system was opened for operation), and by MSA. All systems remained mostly out of balance in favor of employment within 2 miles of transit, with some exceptions.

Tables ES.8 through ES.11 report results for LRT, BRT, SCT and CRT systems, respectively. We summarize key findings below.

The tables below provide summaries of jobs-worker balance across the years before, during, and after the Great Recession, categorized by wage and job sector groups per transit mode for each 
separate generation of each mode. They also include the rate of change in the balance between 2011 and 2015.

Table ES.7: Fixed Route Transit Systems Studied

\begin{tabular}{l|c|l|l|l|l|l|c}
\hline $\begin{array}{l}\text { Light Rail } \\
\text { Transit }\end{array}$ & & \multicolumn{3}{l|}{ Bus Rapid Transit } & $\begin{array}{l}\text { Streetcar } \\
\text { Transit }\end{array}$ & & \multicolumn{2}{l}{ Commuter Rail Transit } \\
\hline 1st Generation & Year & Pioneer & Year & 1st Generation & Year & 1st Generation & Year \\
\hline Buffalo & 1984 & Pittsburgh & 1977 & Little Rock & 2004 & $\begin{array}{l}\text { Dallas-Fort } \\
\text { Worth }\end{array}$ & 1996 \\
\hline Cleveland & 1980 & Pre-Recession & & Portland & 2001 & Miami Tri-Rail & 1989 \\
\hline Pittsburgh & 1984 & $\begin{array}{l}\text { Eugene- } \\
\text { Springfield }\end{array}$ & 2007 & Seattle & 2007 & Minneapolis & 1997 \\
\hline Portland & 1986 & Kansas City & 2005 & Tacoma & 2003 & San Diego & 1995 \\
\hline Sacramento & 1987 & Las Vegas & 2004 & Tampa & 2002 & $\begin{array}{l}\text { San Jose- } \\
\text { Stockton }\end{array}$ & 1998 \\
\hline San Diego & 1981 & Stockton & 2007 & $\begin{array}{l}\text { 2nd } \\
\text { Generation }\end{array}$ & & Seattle-Tacoma & 2000 \\
\hline San Jose & 1987 & Great Recession & & Atlanta & 2014 & Washington, DC & $1980 \mathrm{~s}-$ \\
\hline 2nd Generation & & Cleveland & 2008 & Dallas & 2015 & Pre-Recession & 90 s \\
\hline Dallas & 1996 & Nashville & 2009 & Salt Lake City & 2013 & Albuquerque & 2006 \\
\hline Denver & 1994 & Phoenix & 2009 & Tucson & 2014 & Nashville & 2006 \\
\hline Salt Lake City & 1999 & Reno & 2010 & & & Great Recession & \\
\hline St. Louis & 1993 & Salt Lake City & 2008 & & & Austin & 2010 \\
\hline 3rd Generation & & Seattle & 2010 & & & Portland & 2009 \\
\hline Charlotte & 2007 & Post-Recession & & & & Salt Lake City & 2008 \\
\hline Houston & 2004 & San Antonio & 2012 & & & Post-Recession & \\
\hline Minn.-St. Paul & 2004 & San Diego & 2014 & & & & 2014 \\
\hline Norfolk & 2011 & Washington DC & 2014 & & & & \\
\hline Phoenix & 2008 & & & & & & \\
\hline Seattle & 2003 & & & & & & \\
\hline
\end{tabular}


Change in balance in LRT systems by wage was small across the generations (Table ES.8). By sector, the changes were also small, with most changes being less than $3 \%$. Third-generation systems saw the greatest change, as much as $-4.72 \%$ for a single sector group, manufacturing. Office, manufacturing and education, which saw the largest changes, changed 3\% to $4 \%$ in most generations, tilting away from employment and towards residences.

Table ES.8. LRT Jobs-Worker Balance Ratios and Change by Wage and Sector Group Across Years Before, During, and After Great Recession

\begin{tabular}{|c|c|c|c|c|}
\hline LRT 1st-Gen & 2007 & 2011 & 2015 & $2015 / 2011$ \\
\hline Overall Balance & 1.344 & 1.425 & 1.370 & $-3.87 \%$ \\
\hline \multicolumn{5}{|l|}{ Wage Group } \\
\hline Upper Wage & 1.211 & 1.241 & 1.213 & $-2.28 \%$ \\
\hline Middle Wage & 1.214 & 1.279 & 1.249 & $-2.30 \%$ \\
\hline Lower Wage & 1.114 & 1.146 & 1.129 & $-1.48 \%$ \\
\hline \multicolumn{5}{|l|}{ Economic Group } \\
\hline Manufacturing & 1.177 & 1.214 & 1.181 & $-2.74 \%$ \\
\hline Light Industrial & 1.155 & 1.163 & 1.140 & $-2.00 \%$ \\
\hline Retail-Lodging & 1.101 & 1.126 & 1.115 & $-0.91 \%$ \\
\hline Knowledge & 1.226 & 1.246 & 1.233 & $-1.03 \%$ \\
\hline Office & 1.198 & 1.276 & 1.238 & $-3.03 \%$ \\
\hline Education & 1.110 & 1.149 & 1.135 & $-1.20 \%$ \\
\hline Health & 1.235 & 1.248 & 1.227 & $-1.68 \%$ \\
\hline Arts-Ent-Rec & 1.095 & 1.162 & 1.148 & $-1.26 \%$ \\
\hline LRT 2nd-Gen & 2007 & 2011 & 2015 & $2015 / 2011$ \\
\hline Overall Balance & 1.378 & 1.424 & 1.385 & $-2.76 \%$ \\
\hline \multicolumn{5}{|l|}{ Wage Group } \\
\hline Upper Wage & 0.823 & 0.836 & 0.826 & $-1.22 \%$ \\
\hline Middle Wage & 0.838 & 0.849 & 0.837 & $-1.41 \%$ \\
\hline Lower Wage & 0.783 & 0.787 & 0.776 & $-1.32 \%$ \\
\hline \multicolumn{5}{|l|}{ Economic Group } \\
\hline Manufacturing & 0.744 & 0.752 & 0.745 & $-0.84 \%$ \\
\hline Light Industrial & 0.809 & 0.820 & 0.794 & $-3.20 \%$ \\
\hline Retail-Lodging & 0.777 & 0.780 & 0.771 & $-1.17 \%$ \\
\hline Knowledge & 0.851 & 0.858 & 0.851 & $-0.79 \%$ \\
\hline Office & 0.853 & 0.870 & 0.850 & $-2.22 \%$ \\
\hline Education & 0.762 & 0.756 & 0.750 & $-0.83 \%$ \\
\hline Health & 0.828 & 0.828 & 0.825 & $-0.45 \%$ \\
\hline Arts-Ent-Rec & 0.808 & 0.823 & 0.842 & $2.27 \%$ \\
\hline
\end{tabular}


Table ES.8 LRT Jobs-Worker Balance Ratios and Change by Wage and Sector Group Across Years Before, During, and After Great Recession (continued)

\begin{tabular}{l|r|r|r|r}
\hline LRT 3rd-Gen & $\mathbf{2 0 0 7}$ & $\mathbf{2 0 1 1}$ & $\mathbf{2 0 1 5}$ & $\mathbf{2 0 1 5} / \mathbf{2 0 1 1}$ \\
\hline Overall Balance & 3.071 & 3.354 & 3.075 & $-8.34 \%$ \\
\hline Wage Group & & & & $-1.69 \%$ \\
\hline Upper Wage & 1.458 & 1.508 & 1.483 & $-2.39 \%$ \\
\hline Middle Wage & 1.511 & 1.578 & 1.541 & $-4.05 \%$ \\
\hline Lower Wage & 1.307 & 1.374 & 1.318 & \\
\hline Economic Group & & & & $-4.72 \%$ \\
\hline Manufacturing & 1.311 & 1.348 & 1.284 & $-2.93 \%$ \\
\hline Light Industrial & 1.525 & 1.579 & 1.533 & $-1.53 \%$ \\
\hline Retail-Lodging & 1.233 & 1.291 & 1.271 & $-1.94 \%$ \\
\hline Knowledge & 1.495 & 1.528 & 1.498 & $-3.12 \%$ \\
\hline Office & 1.475 & 1.568 & 1.519 & $-4.19 \%$ \\
\hline Education & 1.347 & 1.391 & 1.333 & $-2.54 \%$ \\
\hline Health & 1.487 & 1.538 & 1.499 & $-2.00 \%$ \\
\hline Arts-Ent-Rec & 1.337 & 1.423 & 1.394 & \\
\hline
\end{tabular}


Overall, as seen in Table ES.9, all BRT generations tilted away from employment and towards residences, but in very small magnitudes. The overall change in balance in BRT systems by generation for the 3 generations are $-3.17 \%,-4.84 \%$, and $-3.7 \%$. In Pittsburgh and pre-recession BRT, upper-wage employment lost the most share. In recession-era systems, middle-wage job lost the most share. Post-recession, all wage categories lost share of the balance. BRT generations, wage categories all changed relatively equally. The exception was Pre-recession BRT routes have a relatively small degree of imbalance, which trend above a value of 1 , which indicates more employment than housing within 2 miles of the stations in these routes. Overall, the pre-recession routes have a lower incidence of imbalance than the BRT routes constructed later.

Table ES.9 BRT Jobs-Worker Balance Ratios and Change by Wage and Sector Group Across Years Before, During, and After Great Recession

\begin{tabular}{|c|c|c|c|c|}
\hline Pittsburgh Pioneer & 2007 & 2011 & 2015 & $2015 / 2011$ \\
\hline Overall Balance & 1.269 & 1.292 & 1.244 & $-3.78 \%$ \\
\hline \multicolumn{5}{|l|}{ Wage Group } \\
\hline Upper Wage & 1.228 & 1.234 & 1.194 & $-3.23 \%$ \\
\hline Middle Wage & 1.192 & 1.183 & 1.169 & $-1.17 \%$ \\
\hline Lower Wage & 1.148 & 1.150 & 1.135 & $-1.28 \%$ \\
\hline \multicolumn{5}{|l|}{ Economic Group } \\
\hline Manufacturing & 1.149 & 1.135 & 1.108 & $-2.37 \%$ \\
\hline Light Industrial & 1.209 & 1.201 & 1.141 & $-5.02 \%$ \\
\hline Retail-Lodging & 1.150 & 1.139 & 1.130 & $-0.85 \%$ \\
\hline Knowledge & 1.260 & 1.250 & 1.222 & $-2.24 \%$ \\
\hline Office & 1.216 & 1.222 & 1.185 & $-2.99 \%$ \\
\hline Education & 1.116 & 1.121 & 1.113 & $-0.70 \%$ \\
\hline Health & 1.190 & 1.196 & 1.190 & $-0.49 \%$ \\
\hline Arts-Ent-Rec & 1.170 & 1.251 & 1.192 & $-4.71 \%$ \\
\hline Pre-Recession BRT & 2007 & 2011 & 2015 & $2015 / 2011$ \\
\hline Overall Balance & 1.396 & 1.524 & 1.476 & $-3.17 \%$ \\
\hline \multicolumn{5}{|l|}{ Wage Group } \\
\hline Upper Wage & 1.165 & 1.199 & 1.161 & $-3.12 \%$ \\
\hline Middle Wage & 1.158 & 1.225 & 1.214 & $-0.88 \%$ \\
\hline Lower Wage & 1.129 & 1.164 & 1.148 & $-1.33 \%$ \\
\hline \multicolumn{5}{|l|}{ Economic Group } \\
\hline Manufacturing & 1.038 & 1.071 & 0.981 & $-8.46 \%$ \\
\hline Light Industrial & 1.098 & 1.132 & 1.156 & $2.18 \%$ \\
\hline Retail-Lodging & 1.126 & 1.174 & 1.163 & $-0.93 \%$ \\
\hline Knowledge & 1.196 & 1.230 & 1.208 & $-1.76 \%$ \\
\hline Office & 1.177 & 1.215 & 1.182 & $-2.70 \%$ \\
\hline Education & 1.176 & 1.215 & 1.188 & $-2.25 \%$ \\
\hline Health & 1.179 & 1.212 & 1.204 & $-0.67 \%$ \\
\hline Arts-Ent-Rec & 1.072 & 1.118 & 1.087 & $-2.76 \%$ \\
\hline
\end{tabular}




\begin{tabular}{|c|c|c|c|c|}
\hline $\begin{array}{l}\text { Great Recession } \\
\text { BRT }\end{array}$ & 2007 & 2011 & 2015 & $2015 / 2011$ \\
\hline Overall Balance & 1.880 & 1.947 & 1.853 & $-4.84 \%$ \\
\hline \multicolumn{5}{|l|}{ Wage Group } \\
\hline Upper Wage & 1.310 & 1.350 & 1.328 & $-1.62 \%$ \\
\hline Middle Wage & 1.375 & 1.409 & 1.362 & $-3.38 \%$ \\
\hline Lower Wage & 1.228 & 1.262 & 1.237 & $-2.03 \%$ \\
\hline \multicolumn{5}{|l|}{ Economic Group } \\
\hline Manufacturing & 1.234 & 1.282 & 1.258 & $-1.87 \%$ \\
\hline Light Industrial & 1.358 & 1.406 & 1.380 & $-1.87 \%$ \\
\hline Retail-Lodging & 1.206 & 1.231 & 1.228 & $-0.18 \%$ \\
\hline Knowledge & 1.333 & 1.349 & 1.333 & $-1.22 \%$ \\
\hline Office & 1.358 & 1.422 & 1.344 & $-5.52 \%$ \\
\hline Education & 1.214 & 1.235 & 1.229 & $-0.48 \%$ \\
\hline Health & 1.307 & 1.327 & 1.307 & $-1.47 \%$ \\
\hline Arts-Ent-Rec & 1.212 & 1.254 & 1.263 & $0.72 \%$ \\
\hline $\begin{array}{l}\text { Post-Recession } \\
\text { BRT } \\
\end{array}$ & 2007 & 2011 & 2015 & $2015 / 2011$ \\
\hline Overall Balance & 1.909 & 1.973 & 1.900 & $-3.70 \%$ \\
\hline \multicolumn{5}{|l|}{ Wage Group } \\
\hline Upper Wage & 1.184 & 1.206 & 1.181 & $-2.03 \%$ \\
\hline Middle Wage & 1.220 & 1.246 & 1.219 & $-2.19 \%$ \\
\hline Lower Wage & 1.127 & 1.151 & 1.128 & $-1.95 \%$ \\
\hline \multicolumn{5}{|l|}{ Economic Group } \\
\hline Manufacturing & 1.044 & 1.097 & 1.090 & $-0.66 \%$ \\
\hline Light Industrial & 1.084 & 1.080 & 1.035 & $-4.18 \%$ \\
\hline Retail-Lodging & 1.115 & 1.124 & 1.107 & $-1.49 \%$ \\
\hline Knowledge & 1.245 & 1.239 & 1.192 & $-3.82 \%$ \\
\hline Office & 1.207 & 1.222 & 1.215 & $-0.55 \%$ \\
\hline Education & 1.142 & 1.207 & 1.165 & $-3.43 \%$ \\
\hline Health & 1.256 & 1.292 & 1.270 & $-1.74 \%$ \\
\hline Arts-Ent-Rec & 1.081 & 1.126 & 1.080 & $-4.07 \%$ \\
\hline
\end{tabular}


Table ES.10 shows that SCT change across the generations overall are significantly tilted away from employment numbers at workplaces, $-9.91 \%$ and $-3.69 \%$. Most changes in balance were small. The biggest percent changes across the study years were in office, which saw a change of $-6.43 \%$, and light industrial, which saw a change of 3.64\%, one of the few sector groupings to increase in favor towards employment in our study. Wage groups saw significant change in the 1st-generation systems but modest changes in the 2nd generation, which saw little change in upper and lower-wage balance, but a modest change toward employment in the middle-wage category. Second-generation SCT systems tilted more towards worker residences than the first generation.

Table ES.10 SCT Jobs-Worker Balance Ratios and Change by Wage and Sector Group Across Years Before, During, and After Great Recession

\begin{tabular}{|c|c|c|c|c|}
\hline 1st-Gen SCT & 2007 & 2011 & 2015 & 2015/2011 \\
\hline Overall Balance & 3.226 & 3.481 & 3.136 & $-9.91 \%$ \\
\hline \multicolumn{5}{|l|}{ Wage Group } \\
\hline Upper Wage & 1.481 & 1.517 & 1.493 & $-1.62 \%$ \\
\hline Middle Wage & 1.496 & 1.592 & 1.548 & $-2.74 \%$ \\
\hline Lower Wage & 1.371 & 1.452 & 1.408 & $-3.02 \%$ \\
\hline \multicolumn{5}{|l|}{ Economic Group } \\
\hline Manufacturing & 1.235 & 1.261 & 1.241 & $-1.63 \%$ \\
\hline Light Industrial & 1.515 & 1.563 & 1.548 & $-0.95 \%$ \\
\hline Retail-Lodging & 1.293 & 1.352 & 1.364 & $0.91 \%$ \\
\hline Knowledge & 1.567 & 1.552 & 1.542 & $-0.67 \%$ \\
\hline Office & 1.511 & 1.664 & 1.558 & $-6.34 \%$ \\
\hline Education & 1.517 & 1.514 & 1.482 & $-2.05 \%$ \\
\hline Health & 1.443 & 1.523 & 1.485 & $-2.47 \%$ \\
\hline Arts-Ent-Rec & 1.309 & 1.394 & 1.429 & $2.52 \%$ \\
\hline 2nd-Gen SCT & 2007 & 2011 & 2015 & 2015/2011 \\
\hline Overall Balance & 1.757 & 1.660 & 1.598 & $-3.69 \%$ \\
\hline \multicolumn{5}{|l|}{ Wage Group } \\
\hline Upper Wage & 0.919 & 0.936 & 0.931 & $-0.55 \%$ \\
\hline Middle Wage & 0.984 & 0.956 & 0.972 & $1.64 \%$ \\
\hline Lower Wage & 0.857 & 0.863 & 0.862 & $-0.05 \%$ \\
\hline \multicolumn{5}{|l|}{ Economic Group } \\
\hline Manufacturing & 0.800 & 0.815 & 0.818 & $0.47 \%$ \\
\hline Light Industrial & 0.854 & 0.864 & 0.896 & $3.64 \%$ \\
\hline Retail-Lodging & 0.833 & 0.841 & 0.839 & $-0.25 \%$ \\
\hline Knowledge & 1.013 & 1.028 & 1.020 & $-0.87 \%$ \\
\hline Office & 0.973 & 0.966 & 0.964 & $-0.17 \%$ \\
\hline Education & 0.910 & 0.894 & 0.894 & $0.06 \%$ \\
\hline Health & 0.904 & 0.887 & 0.869 & $-2.05 \%$ \\
\hline Arts-Ent-Rec & 0.912 & 0.941 & 0.937 & $-0.44 \%$ \\
\hline
\end{tabular}


Commuter rail changed overall by tilting more towards housing employees and more away from workplaces, shown in Table ES.11. As in the other transit modes, changes were mainly small in degree with some considerable exceptions. The second-generation CRT lines saw a significant drop in the ratio value for education. This may be due to a loss of education jobs. It may also be due to a gain in relevant housing, such as student housing. Second-generation systems, those from pre-recession and post-recession systems saw the most significant changes. In both generations balance tilted toward jobs only slightly in the upper-wage category; the other wage categories tilted more away from employment.

Table ES.11 CRT Jobs-Worker Balance Ratios and Change by Wage and Sector Group Across Years Before, During, and After Great Recession

\begin{tabular}{|c|c|c|c|c|}
\hline 1st-Gen CRT & 2007 & 2011 & 2015 & $2015 / 2011$ \\
\hline Overall Balance & 1.280 & 1.770 & 1.728 & $-2.32 \%$ \\
\hline \multicolumn{5}{|l|}{ Wage Group } \\
\hline Upper Wage & 0.849 & 1.104 & 1.098 & $-0.54 \%$ \\
\hline Middle Wage & 0.803 & 1.081 & 1.069 & $-1.17 \%$ \\
\hline Lower Wage & 0.759 & 1.025 & 1.015 & $-1.02 \%$ \\
\hline \multicolumn{5}{|l|}{ Economic Group } \\
\hline Manufacturing & 0.900 & 1.052 & 1.023 & $-2.69 \%$ \\
\hline Light Industrial & 0.860 & 1.049 & 1.037 & $-1.11 \%$ \\
\hline Retail-Lodging & 0.755 & 1.005 & 0.997 & $-0.85 \%$ \\
\hline Knowledge & 0.797 & 1.166 & 1.170 & $0.33 \%$ \\
\hline Office & 0.816 & 1.111 & 1.090 & $-1.90 \%$ \\
\hline Education & 0.718 & 1.003 & 1.003 & $0.00 \%$ \\
\hline Health & 0.779 & 1.021 & 1.021 & $0.01 \%$ \\
\hline Arts-Ent-Rec & 0.832 & 1.062 & 1.078 & $1.52 \%$ \\
\hline 2nd-Gen CRT & 2007 & 2011 & 2015 & $2015 / 2011$ \\
\hline Overall Balance & 1.813 & 1.946 & 1.861 & $-4.36 \%$ \\
\hline \multicolumn{5}{|l|}{ Wage Group } \\
\hline Upper Wage & 1.004 & 1.029 & 1.036 & $0.77 \%$ \\
\hline Middle Wage & 1.061 & 1.102 & 1.053 & $-4.47 \%$ \\
\hline Lower Wage & 0.966 & 1.008 & 0.984 & $-2.35 \%$ \\
\hline \multicolumn{5}{|l|}{ Economic Group } \\
\hline Manufacturing & 1.039 & 1.030 & 1.040 & $0.93 \%$ \\
\hline Light Industrial & 1.044 & 1.096 & 1.069 & $-2.39 \%$ \\
\hline Retail-Lodging & 0.957 & 0.971 & 0.981 & $1.03 \%$ \\
\hline Knowledge & 1.001 & 1.045 & 1.061 & $1.53 \%$ \\
\hline Office & 1.022 & 1.084 & 1.052 & $-3.00 \%$ \\
\hline Education & 1.039 & 1.117 & 0.976 & $-12.62 \%$ \\
\hline Health & 0.962 & 0.993 & 0.990 & $-0.40 \%$ \\
\hline Arts-Ent-Rec & 0.902 & 0.900 & 0.878 & $-2.41 \%$ \\
\hline
\end{tabular}


Implications for policy makers and planners include the recommendation to review the balance figures for a particular MSA. They show overall that employment remains a greater presence near transit than residences. This is a highly pronounced trend across the US: $5 \%$ of all residents and $48 \%$ of all jobs in the US are within a half-mile of FRT stations! Massive opportunity exists within 2 miles of transit stations to increase accessibility and jobs-worker balance while supplying the increasing preference for living near transit. As highlighted in chapter 9, greater proximity to transit, which greater balance will facilitate, will lower household transportation expenses for those who need it the most. 


\section{Chapter 8-The Link between Fixed Route Transit Station Planning and Design, and Development Outcomes}

This chapter asserts that FRT station planning (the process leading to locations) and design (how stations are integrated with transport systems and nearby land uses) can dictate (a) use of the system by passengers, (b) development outcomes around the station, sometimes to a few miles away, and (c) real estate markets. The vast literature on FRT station planning and design may boil down to these over-arching principles:

- Reduce adverse impacts of transit stations on surrounding land uses;

- Facilitate positive interactions between land uses near stations; and

- Maximize accessibility of passengers to transit stations and nearby land uses.

Unfortunately, as we show in Chapter 8, poor station planning and design can actually undermine these principles thereby dampening development outcomes. In our Appendix B of the main report, we offer a visual perspective on what constitutes "good" and "bad" station locations and design. We include walk, bike and transit (WBT) scores for each example. Some "good" station locations and design have low to modest WBT scores while others that in our opinion are "bad" locations and design have modest to high WBT scores.

We also aggregated WBT scores for all LRT systems and compared to our typology of "good", "bad", and "ugly" office market rent outcomes reported for 17 systems in Chapter 2. Good systems were those with statistically significant positive associations between rent and station proximity, bad systems were those without any statistically significant associations, and ugly systems were those with statistically significant negative associations. Table ES.12 presents our results. While all the "ugly" systems are in the bottom half of this table, "good" and "bad" ones based on mean WBT system wide scores are roughly equally distributed.

We conclude that there does not appear to be an easy way to predict transit station development outcomes based on transit station planning and design. This is an area where new research is needed. 
Table ES.12: Comparing Market Rent Typology to LRT System Mean Walk-Bike-Transit Scores from Highest to Lowest

\begin{tabular}{|c|c|c|c|c|c|}
\hline LRT System & Walk & Transit & Bike & WBT Mean & Rent Premium \\
\hline Portland & 75.1 & 71.8 & 85.5 & 77.5 & Good \\
\hline Seattle & 78.9 & 79.0 & 72.7 & 76.9 & Bad \\
\hline Minneapolis-St. Paul & 70.7 & 73.7 & 78.9 & 74.4 & Bad \\
\hline Buffalo & 82.9 & 64.5 & 74.6 & 74.0 & Bad \\
\hline Houston & 70.7 & 70.7 & 71.6 & 71.0 & Good \\
\hline Phoenix & 69.3 & 58.2 & 72.7 & 66.7 & Bad \\
\hline Sacramento & 59.2 & 52.0 & 76.4 & 62.5 & Bad \\
\hline San Diego & 67.4 & 59.7 & 59.1 & 62.1 & Ugly \\
\hline Denver & 55.0 & 60.6 & 70.3 & 62.0 & Good \\
\hline Salt Lake City & 55.5 & 62.2 & 66.8 & 61.5 & Bad \\
\hline Charlotte & 63.0 & 60.8 & 55.9 & 59.9 & Good \\
\hline San Jose & 52.7 & 52.8 & 73.8 & 59.8 & Ugly \\
\hline Dallas & 53.7 & 61.1 & 56.5 & 57.1 & Good \\
\hline Cleveland & 52.7 & 58.0 & 50.8 & 53.8 & Bad \\
\hline Norfolk & 52.5 & 53.5 & 50.7 & 52.2 & Good \\
\hline Pittsburgh & 56.3 & 60.0 & 38.4 & 51.6 & Ugly \\
\hline St. Louis & 48.0 & 50.9 & 55.5 & 51.5 & Ugly \\
\hline
\end{tabular}

Source: Analysis by authors using walk, bike and transit scores for each LRT station for each system as provided by https://www.walkscore.com/. 


\section{Chapter 9-The Link between Household Transportation Cost and Transit Station Proximity}

It seems an article of faith that transportation costs as a share of household income increase with respect to distance from downtowns, freeway interchanges, and fixed route transit (FRT) stations. Considerable literature reports price effects of these points on residential property values but none measure explicitly differences in household transportation costs as a share of household budgets. This chapter helps close this gap in literature. Our research question is:

\section{Do transportation costs as a share of median household incline decline with respect to light rail transit station proximity controlling for other factors?}

We use the U.S. Department of Housing and Urban Development's (HUD) Location Affordability Index (LAI) database, versions 2 and 3, They estimate the share of household budgets consumed by transportation at the block group level based on the 2012 5-year American Community Survey (ACS) and census tracts based on the 2016 5-year ACS, respectively. Using them, we evaluate the association between median household transportation costs and distance from light rail transit (LRT), bus rapid transit (BRT) and streetcar transit (SCT) stations using both ACS data sets. We apply our analysis to those systems we have evaluated throughout this report: 17 LRT systems, 13 BRT systems and 9 SCT systems (see Table ES.1). All these systems were operating at the time of the 2016 5-year ACS while nearly all were operating concurrent with the 20125 -year ACS. We use the standard-form ordinary least squares regression model adapted for our purposes:

Figure ES.13 illustrates our findings. In that figure, we note that lines for 2016 5-year ACS are less smooth than for the 2012 5-year ACS. The reason is the difference in geography where 2016 is based on coarse CTs while the 2012 geography is the more fine-gained CBGs.

For LRT systems, the typical regional households budget improved by an order of about one-half of one percent between 2012 and 2016 when considering transit station proximity. But for BRT systems, the improvement was more than one percent (or roughly a $25 \%$ increase in savings). In contrast, there was not no discernable change in savings associated with SCT station proximity between 2012 and 2016.

We observe that for the most part, there was only a nominal change in the number of LRT and BRT systems between 2012 and 2016 - the San Diego BRT system was added in 2014, though San Antonio was added in 2012. The implication is that as systems mature and markets have time to respond to FRT systems, there may be some marginal shifting of residential development accordingly. This must not be over-stated however, as the household budget savings while not trivial are also not very large.

That households' share of income devoted to transportation increases with respect to FRT stations to at least two miles elicits two important policy implications from us.

First, our findings may be used to relax early efforts to calibrate location-efficient mortgages (LEM). For the most part, the LEM calculations were weighted substantially toward the central business district. Considering just this limitation, prior research concluded that LEMs do not raise mortgage default rates and should be weighed against anti-sprawl benefits they may offer. 
We suspect default rates will be lower the closer properties are to FRT stations. Further research may explore the relationship between proximity to LRT stations if not all fixed guideway transit stations and foreclosure rates.

Second, assumptions about planning land uses around FRT stations may need to be relaxed. The so-called half-mile circle planning area has coming under increasing challenge with studiesincluding our own (see references in Chapter 9) showing market responsiveness transit station proximity up to two miles. Our empirical analysis suggests that FRT station planning protocols may need to extend many miles from stations.

The nation will add about 100 million people between now and mid-century. One of us (Nelson) has estimated that about a quarter of American households want to live near fixed guideway transit opportunities though less than 10 percent have those options now. Perhaps one reason is that Americans understand the cost savings associated with living near transit stations. Yet, even if all new homes built between now and mid-century were located near existing or planned fixedguideway transit stations the demand for living near those stations would still not be met. 


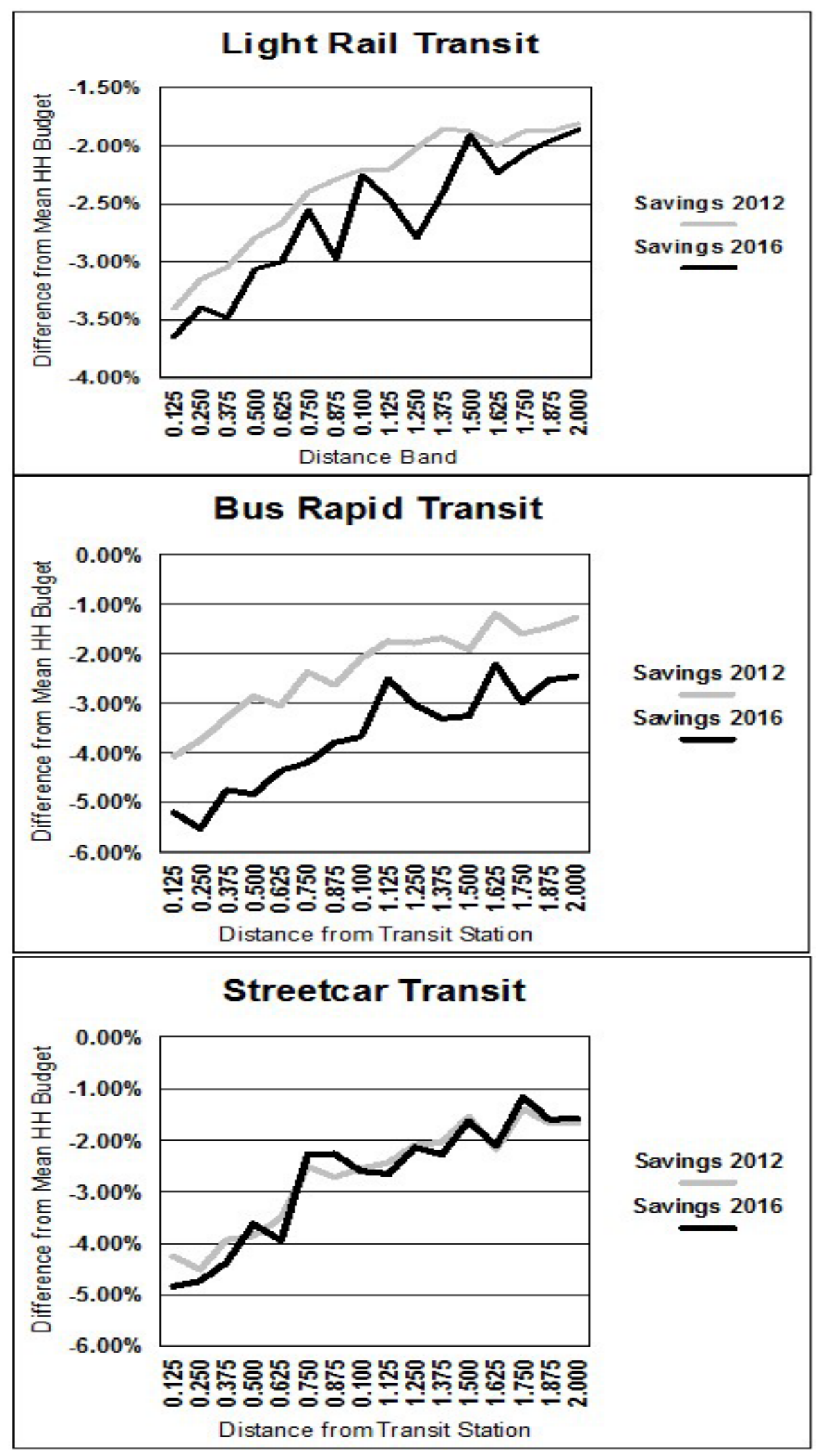

Figure ES.3: Illustration of the Association between Transit Station Proximity and Typical Regional Household Transportation Costs as a Percent of Regional Median Household Income 


\section{CHAPTER 10-The (Overlooked) Link between Express Bus Stations and Commercial Rents with Implications for Transit and Land Use Planning}

This chapter provides the first study establishing the association between express bus transit (XBT) stations and commercial office, apartment and retail rents. Nearly if not all research reporting the association between transit and real estate values focuses on heavy rail (also called third rail), light rail, streetcar (also called trolley), commuter rail, and bus rapid transit. Forgotten in the research is the influence that express bus systems and their stations can also have on real estate values or rents. This research helps close the gap. Our research question is:

\section{Is there an association between commercial real estate rent (per square foot) and proximity to $X B T$ stations holding other factors constant?}

We apply standard ordinary least squares analysis to XBT systems operating in more than 30 metropolitan areas. Modeling and analytic details are presented in Chapter 10, the association between commercial rents and XBT proximity are illustrated in Figure ES.14.

Overall, we find surprisingly robust associations between XBT stations on office and apartment rents well beyond one mile, and strong associations with respect to retail rents although these are limited to locations closest to XBT stations. With respect to XBT station distance bands, we find:

- Office rents decline gradually from the first distance band to the 1.625-mile distance band;

- Multifamily rents decline gradually from the first distance band to the 1.875-mile distance band; and

- Retail rents begin with a positive premium at the first distance then fall steeply over the next two distance bands.

These empirical outcomes are surprising with respect to the distance over which there seems to be a rent premium with respect to office and multifamily properties being more than 1.5 miles and nearly 2.0 miles respectively. They are comparable to the distances found in Chapter 2 for multifamily rents for SCT and CRT systems but in other respects being much longer.

A key finding is that it appears that offices and apartments value proximity to XBT stations much more so than BRT stations. In Chapter 2, we found no rent premiums for office, apartments or retail buildings in the first (0.125 mile) distance band with limited premiums only to about one mile away.

We caution that, like CRT systems, XBT systems tend to operate less frequently than other FRT systems. 


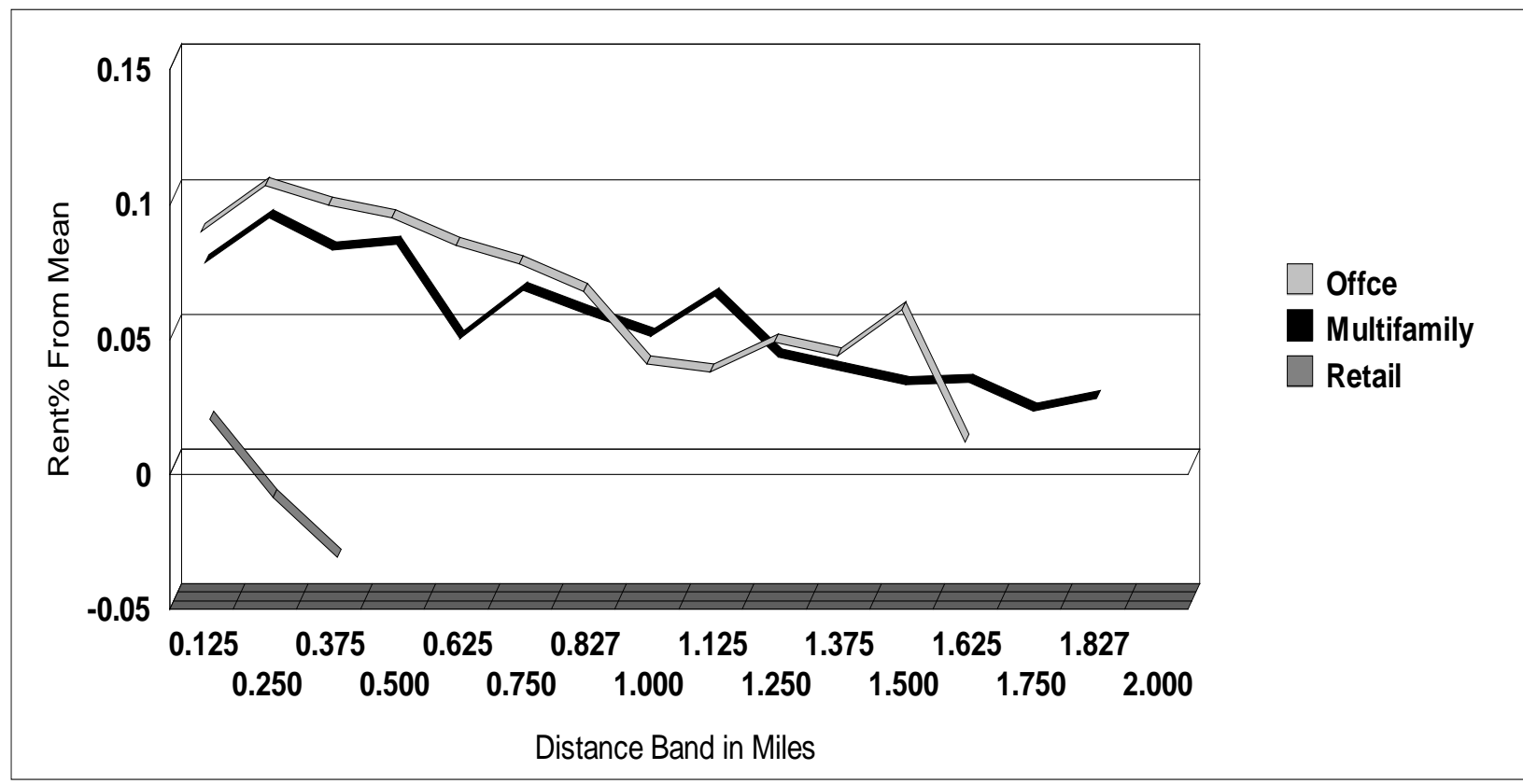

Figure ES.4: The percent rent change from the mean between XBT station proximity and office, multifamily and retail rents per square foot 


\section{Chapter 11-The Link between Transit and Land Use Planning to Meet America's Market Demand for Transit Station Proximity}

Our concluding chapter includes a research agenda and a perspective on the role of fixed route transit systems.

\section{Research Agenda to Further Understand the Role of Fixed Route Transit Systems in Shaping Development Patterns}

The current research, which builds on our prior research, creates the platform for what we call the FINAL PHASE of this research genre. It would need to include development and hedonic analyses, both of which we pioneered for their application to fixed guideway transit systems. The following agenda is envisioned

\section{Spatial Economic Analysis}

Our prior and ongoing research uses quasi-experimental, economic base methods to assess change in concentration in workers and their wages by economic groups; people and households by race/ethnicity, age, type and other demographic features; housing by tenure; and mode choice to work. Using factor/cluster analysis, we would refine analysis to consider outcomes with respect to types of transit stations by mode considering such dimensions as: land use mix (an entropy measure), jobs-population balance (a measure of jobs versus population concentration), distance to downtown and other major activity centers (a centrality measure), employment sector composition (a measure of economic concentration); and socioeconomic composition (a measure of demographic concentration).

We anticipate that there may be surprises compared to our prior work, such as gains in concentration at types of transit stations that otherwise saw losses of concentration for systems as a whole, and vice versa. Refined analysis can lead to refined planning and urban design practices.

\section{Hedonic Analysis}

We pioneered the use of CoStar rent data to assess the association between transit station distance and rent with respect to different system types and metropolitan areas. Our FINAL PHASE would disaggregate systems into types of stations based on factor/cluster analysis outlined above. We would also be mindful of opportunities to apply more rigorous analyses including larger numbers of economic, demographic and spatial controls. We anticipate advancing work in this field in another way: assessing the interactive effect of transit station type and distance on commercial properties within discrete distance bands of stations. In our current work, we have discovered that commercial markets express segmentation effects based on distance to transit stations, by mode. For instance, commercial property rents are much more responsive to BRT station proximity than to SCT proximity for reasons that are different between these systems. The FINAL PHASE research agenda would allow us to explore these refinements to market responses to transit systems by mode, type and distance.

We conclude with a review of why all this research is important. 


\section{Perspectives about the Role of Fixed Route Transit Systems in Meeting America's Future Development Needs}

Two perspectives emerge from this research. First, the real estate market values proximity to various forms of transit, often extending up to two miles away. In other words, the real estate market confers a premium on rents for many kinds of commercial real estate beyond the standard half-mile circle that seems to dominate transit-oriented development (TOD) planning.

The second is that for the most part changes in jobs, people and households are confined to the very closest distance bands around transit stations. While it makes sense for development that values transit station proximity to occur nearby, there may be opportunities for transit-oriented development farther away that are unrealized. For instance, a substantial literature indicates that firms are attracted to transit stations up to a mile and often further away. It is not that workers are necessarily willing to walk longer distances but often feeder buses, shuttles, and even pleasant and barrier free walkways/bikeways facilitate accessibility.

Moreover, there is a growing literature based on market surveys indicating that people would choose to live a half mile away, or more, from transit stations if they had the opportunity. One indicator of this willingness is the presence of market premiums for light rail and streetcar proximity well beyond one mile (see Chapter 2). Yet, the largest share of the change people and households occurs within one-eighth (0.125) mile of LRT and SCT stations (see Chapter 5). For workers it is the first quarter (0.25) mile (see Chapter 3$)$. Why is this?

It may be that local planning does not seize market opportunities for maximizing development throughout the half-mile circle or beyond. Among many barriers identified in the literature combined with our own professional observations include:

- Development regulations that are inconsistent with market realities;

- Unpredictable or protracted development approval processes;

- $\quad$ Excessive parking requirements;

- Development exactions that exceed that needed to mitigate adverse impacts;

- Neighborhood opposition;

- Inefficient linkages between development and transit stations (such as multi-lane highways, long blocks, and elevated station platforms among others); and

- Insensitive urban design that makes transit station accessibility physically and even emotionally unpleasant.

But for these barriers, more jobs, people and households are likely to locate within a half mile, a mile or more from transit stations. For example, suppose development across the entire 0.50mile area around transit stations were similar to that observed for the first 0.125 -mile. For instance, in metropolitan Denver, the 0.125-mile LRT station areas absorbed $8.7 \%$ of all household growth despite comprising only $0.4 \%$ of the urban land area. If extended over 0.50 - 
mile, 1.5 times more than all of the Denver metropolitan area's household growth 2010-2016 could have been absorbed. Not all households would choose to live near transit stations, of course. Still, market surveys produced by the National Association of Realtors suggest that even if all new housing built between 2010 and 2050 were within 0.50-mile of existing transit stations, market demand for housing proximate to transit stations would remain unmet.

There is another consideration. Our preliminary analysis of the land area within 0.50 mile of transit stations in many of the metropolitan areas investigated in our study indicate that more than half the area is comprised of

- $\quad$ Surface parking lots,

- Vacant, privately owned land, and

- $\quad$ Land on which there are one- and two-floor structures being more than 30 years old and occupying less than $25 \%$ of the land area. 1

Real estate development literature indicates such land presents important opportunities for infill and redevelopment. One may imagine that much of the America's market demand for living and working near transit stations can be accommodated through the redevelopment of parking lots, vacant land, and aging buildings that are already beyond their highest and best use.

Perhaps the greatest challenge for America's metropolitan areas is to meet the market demand for jobs and housing near rail transit stations by simply facilitating the redevelopment of its parking lots and aging, low intensity structures.

1 These analyses are based on assessor records and Marshall and Swift depreciation schedules by building types. 


\subsection{INTRODUCTION TO RESEARCH INTO THE LINK BETWEEN TRANSIT STATION PROXIMITY AND COMMERCIAL RENTS, JOBS, PEOPLE AND HOUSING WITH IMPLICATIONS FOR TRANSIT AND LAND USE PLANNING}

\subsection{OVERVIEW}

The National Institute for Transportation and Communities (NITC) has sponsored research led by one of us (Nelson) that has created a particular genre of work which relates transit systemsand transit stations especially - to development outcomes using economic base analysis, notably location quotient and shift share analysis, and hedonic analysis of commercial rent. This report updates and expands prior research in this genre. Under prior NITC contracts, research teams built station area databases for 12 light rail transit (LRT) systems, nine bus rapid transit (BRT) systems, four streetcar transit (SCT) systems, and five commuter rail transit (CRT) systems. Prior research included employment data extending annually from 2002 through 2011, and census data for 2000 and 2010. Prior analysis compared development, demographic and housing outcomes associated with those transit systems during the period before the Great Recession (2000 through 2007) and during recession into recovery (2008 through 2011).

Although NITC researchers found important differences in outcomes between the study periods of 2000-2007 and 2008-2011, their research could not measure outcomes during the period of economic stability that commenced about 2012. This report expands the number of systems used in analysis to 17 LRT systems, 14 BRT systems, nine SCT systems and 12 CRT systems. It also expands the period of analysis to 2015 for jobs-related data and to 2016 for census data. The expanded and updated databases allow for more comprehensive assessment of their outcomes. Those data have been made available for open access use by researchers.

Prior NITC-sponsored research included analysis of the relationship between office, retail and multifamily rents and transit station proximity by type of transit, controlling for the usual influences. This report expands upon earlier work to include many more transit systems, new variables, and more recent rent data.

This introduction casts our research effort in terms of:

- Literature gaps;

- Overarching themes;

- Background and objectives;

- Methodology summary; 
- Technology transfer; and

- Broad impacts. 


\subsection{OVER-ARCHING LITERATURE GAPS}

Light rail transit (LRT), bus rapid transit (BRT), streetcar transit (SCT) and commuter rail transit (CRT) systems are growing in number and expanding where they exist. Numerous claims are made about how they will influence the location of jobs by type of sector and wages, people and their housing choices and tenure, and real estate market values, but the evidence is scant. Until our prior work (Nelson 2015; Nelson et al. 2015a), there was no systematic assessment of the performance of LRT/BRT/SCT/CRT systems on development outcomes across the nation, while controlling for the distance to transit and differentiated by type of transit system among other factors. (See CTOD 2011 for the only prior study examining location relative to transit location but with limitations).

Using keywords relating to station area economic development for published works in the past five years, we find only 14 studies identified in the Transportation Research Information Database, but except for work led by Nelson, none address multiple systems in multiple metropolitan areas. Of two studies cited using keywords relating to station area population change, ours is the only one based on multiple transit systems in multiple metropolitan areas. Moreover, except for ours (see Nelson 2017a for a summary), no study reports variation in employment by wage with respect to transit systems. Previously, Nelson et al (2015b) published the largest metropolitan-specific study relating LRT to office rents based on the Dallas metro area. Soon, Nelson (2017b) will publish the only study showing variation in market rents for office, retail and rental apartment properties with respect to one-half mile corridors for different types of transit systems. And except for Petheram and Nelson et al. (2014), no hedonic study systematically associated apartment building values to LRT station proximity with respect to distance beyond one-half mile.

Using NITC resources and those of several partners, research teams headed by Nelson have created a unique genre of spatially-based development outcome research that is national in scope, and which includes all fixed route transit types except for heavy rail. Key findings from prior research has indicated:

- Before the Great Recession (GR), transit station areas lost a share of jobs relative to their regions but during the GR and early recovery years they gained share-how much depended upon the type of transit system, distance from stations, and sector. BRT, for instance, gained job share only within the first one-quarter mile (see Nelson et al. 2013), while LRT and SCT stations gained share up to a mile away. CRT stations lost share during both time periods.

- Before the GR, transit station areas lost share of higher-wage jobs relative to their regions, but during the GR and early recovery years, LRT station areas gained upper- and middle-wage job share while losing lower-wage ones; SCT station areas gained upperand lower-wage job share but lost middle-wage jobs, while BRT station areas lost share of all jobs by wage category (though there were exceptions for individual systems).

- As expected, LRT and SCT station areas gained a small share of their region's population between the pre-GR and GR-recovery periods, but surprisingly the effect was roughly 
equal for those under 35 ("Millennials") and those 35-64-while declining shares occurred at 65 and older. BRT station areas lost share across all age groups.

- Market rents for office, retail and apartment properties with respect to distance from different kinds of transit systems varied considerably - LRT and SCT had the largest positive effects, BRT modest and limited positive effects, and CRT had negative effects.

There is another area of work that is lacking in the literature: the extent to which median household transportation costs vary with respect to transit station distance and whether variations change over time.

The study period for prior work extended to only 2011, which many consider still part of the Great Recession. Earlier work also included many systems that did not commence operations until the late 2000s, which compromises fidelity in the establishment of reasonable longitudinal associations. By extending the study period to 2015, we are able to test for the resiliency of associations found before and during the Great Recession. Because we cannot analyze all the potential relationships our database supports, we have "democratized" our data through NITC open source download of excel database and shape files with a data dictionary. This allows researchers, scholars, policy analysts and students to address research questions ranging from the perspective of a single station area to multiple metropolitan areas, and for a single transit system to multiple ones.

\subsection{OVERARCHING THEMES}

NITC research focuses on a number of themes. The focus of this report is on these three:

Increasing access to opportunities: Well-connected regions and communities can improve social equity by providing access to jobs, services, recreation, and social opportunities.

Our research expands on prior related work to assess the extent to which jobs and people are attracted to transit station areas with respect to jobs by wage level and households by income, and transportation costs with respect to station distance. This part of our analysis focuses especially on equity concerns.

Improving multi-modal planning and shared use of infrastructure: Improved mobility requires a range of options for moving people and goods.

Our analysis improves understanding of how cities and regions vary in the performance of development outcomes associated with transit through estimations of rent premiums, or the willingness of the market to pay for transit station proximity. Our analysis thus implicitly generates the evidence needed by planners to demonstrate the benefits of transit systems in the context of multi-modal transportation systems.

Developing data, models, and tools: Our complex transportation system demands better data and tools for decision-making.

We have made our databases and shape files available open source through NITC. This democratization of data enhances examination of the implications of changes to transit system on 
a range of outcomes relating to mobility, economic equity, the environment, and health at a variety of scales (from the station area to the nation) by researchers, policy analysts and students everywhere.

\subsection{BACKGROUND AND OBJECTIVES}

Prior research has established that development outcomes for LRT/BRT/SCT/CRT systems vary by type of system and station distance, among other factors. But prior work was limited to the period before the Great Recession (2000-2007) and during the Great Recession/early recovery years (2008-2011). This research was further limited because many BRT systems emerged in the late 2000s while many LRT, BRT and SCT systems have been added or expanded since then. The key problem is that we do not know whether trends (central tendencies) seen before the Great Recession and during the Great Recession/early recovery study periods have been sustained, accelerated or lessened during the post-recession period (2012-2015 based on jobs data and 2010-2016 based on census data). Our research is guided by three overarching research questions:

Q1: $\quad$ Have trends seen during the pre-Great Recession and Great Recession/early recovery years changed during the post-Great Recession period?

This analysis includes each transit system for each metropolitan area studied during appropriate time periods for that system, as well as systems combined across metro areas. Trends measured include:

- Changes in the number and share of jobs by sector with respect to type of system and distance from stations;

- Changes in the number and share of jobs by wage category with respect to type of system and distance from stations; and

- Changes in number and share of population, households, householders by age, and housing by tenure with respect to type of system and distance from stations.

Q2: Does transit station proximity reduce median household transportation costs and do transportation costs vary by type and maturity of system?

While one might assume that transit accessibility is associated with lower household transportation costs, prior research is skimpy. Although our work explores the variation in median household transportation costs with respect to type of system and distance from stations for one point in time, we also consider the maturity of systems.

Q3: How does the real estate market for office, retail and apartment properties respond to proximity to transit stations?

Our prior work pioneered the use of CoStar commercial rental data for very broad assessments of real estate market responsiveness to transit by type while measuring distance in ordinal spatial bands. The current research provides more refined relationships in those metropolitan areas where CoStar data is sufficient for analysis. There are many surprises. 
In addition, we compiled our complete database and shape files along with a codebook and made this publicly accessible through NITC. We intend for this to be a resource that advances research and supports policy decisions related to LRT/BRT/SCT/CRT systems planning across the nation and possibly the world.

\subsection{METHODOLOGY SUMMARY}

Our research updates prior NITC-sponsored studies which inform decision-makers about whether and the extent to which LRT/BRT/SCT/CRT systems affected development outcomes before the Great Recession, during the Great Recession/recovery, and afterward, and whether those trends changed between study periods. We also expand our databases to include many other systems and other metropolitan areas, largely to account for new systems added since the late 2000s. We use quasi-experimental analysis to explore associations between transit stations and systems on employment and demographic changes over time. We also employ hedonic real estate rent analysis to detect whether and the extent to which different types of transit systems confer differing levels of rent premiums spatially.

\section{Employment and Demographic Quasi-Experimental Analysis}

Quasi-experimental analysis lends itself to comparing change over time in the experimental subject systems versus controls. The experimental subjects are the transit station areas themselves, which we geocoded to allow for continuous or zonal analysis with respect to independent variables. The control subjects are the balance of the metropolitan county or area within which systems operate (called "transit" counties). Our analysis explored associations between transit stations spatially by age and type of system, and metropolitan area with respect to (a) jobs by sector and (b) jobs by wage category before (2004-2007), during (2008-2011) and after (2012-2015) the Great Recession. Conveniently, these are equal 4-year periods. We also evaluated changes in population and households by age and other demographic features along with residential units by tenure before and into the Great Recession (2000-2009) and from the Great Recession to full recovery (2010-2016). With respect to these specific analyses:

- $\quad$ For jobs, we used the Longitudinal Employer-Household Dynamics (LEHD) database. It generates job data annually since 2002 for all states in our analysis (since 2004 for Arizona) at the census block, block group and tract levels.

- For demographic data, we used the decennial census for 2000 and 2010, as well as the 1-year American Community Survey for 2009 and 2016. These data are collected at the block group level.

- For new demographic analysis, we will use HUD’s Location Affordability Index database for three time periods. These periods cover the GR, early recovery years and post-GR periods, which allows for first-ever evaluation of change in median household transportation costs at the block group level with respect to transit station proximity and age of station controlling for socioeconomic, spatial and other factors.

We used data collection, aggregation and processing protocols which we developed in prior work (see Nelson 2015; Nelson et al. 2015) to allow for consistent comparisons. Descriptive, difference of means and shift-share analyses generate overall central tendencies. 


\subsection{HEDONIC REAL ESTATE RENT ANALYSIS}

Prior research led by Nelson basically pioneered the use of CoStar rent data to assess the association between transit station distance and rent with respect to different system types and metropolitan areas (see Nelson et al. 2015 and Nelson 2017b). But prior work lacked consistent spatial measures and did not include census demographic or other spatially-related controls. The new analysis improves on these shortcomings. The analysis is applied to (a) office, (b) rental apartment and (c) retail real estate.

\subsection{TECHNOLOGY TRANSFER}

The intended users of our research include practitioners, policy makers, researchers/academics, and planners. For them, we have generated an excel database and shape files for NITC that was made freely available to users who can analyze data from the station level up to the metropolitan area for one or more systems. The database structure includes data at the block, block group and tract level and is assigned to the nearest station of the same transit type. Data are from the LEHD and census. These data may allow the user to conduct fine-grained analysis of job change by sector, changes in demographic outcomes, and changes in housing and related measures over time. This will allow analysts to assess the extent to which LRT/BRT/SCT/CRT stations and station areas are associated with change, and suggest similar magnitudes of change for new or expanded systems. The database can put local transit interests in the position of offering objective evidence of transit outcomes.

\subsection{ORGANIZATION OF THE REPORT}

Aside from an Executive Summary and this introductory chapter, the report has the following chapters and appendices (in addition to appendices appearing in many individual chapters):

Chapter 2 - The Link between Transit Station Proximity and Commercial Real Estate Rents with Implications for Transit and Land Use Planning

Chapter 3 - The Link between Transit Station Proximity and Jobs by Economic Group Before, During and After the Great Recession with Special Reference to Resilience

Chapter 4 - The Link between Transit Station Proximity and Jobs by Upper, Middle and Lower Wage Groups

Chapter 5 - The Link between Transit Stations and People and Housing

Chapter 6 - The Link between Transit Station Proximity and Commuting Modes

Chapter 7 - The Link between Transit Station Proximity and Jobs Housing, and Jobs Labor Force Balance

Chapter 8 - The Link between Fixed Route Transit Station Planning and Design, and Development Outcomes 
Chapter 9 - The Link between Transit Station Proximity and Total Household

Transportation Costs and Costs as a Share of Income

Chapter 10 - The (Overlooked) Link between Express Bus Stations and Commercial Rents with Implications for Transit and Land Use Planning

Chapter 11 - The Link between Transit and Land Use Planning to Meet America's Market Demand for Transit Station Proximity

Appendix A - Survey of Transit Systems used in Research

Appendix B - Selected FRT Stations for Perceptual Good-Bad-Ugly Assessment

This report is in the public domain.

\subsection{BROAD IMPACTS}

NITC strives to achieve broad impacts with the research it sponsors.

What long-lasting impact might this research have?

America will add at least 100 million new residents, 40 million new households, and 60 million new jobs by 2050. We know from demographic analysis and consumer preference surveys that in 2050 approximately a third of America's 150 million households (50+ million) will want to live in locations that provide them with transit, mixed-use, and mixed-housing options. We also know from research on firm location behavior that up to 100 million jobs will be attracted to locations with transit options. What we do not know is whether and the extent to which LRT/BRT/SCT/CRT systems are already meeting the growing demand. Our research will likely help guide LTR/BRT/SCT/CRT planning, design, investment, and implementation for many years if not decades to come.

Are there any opportunities for leveraging of the research results for future research or practice?

Our products include an excel database with data dictionary that has been made available for free download from NITC. This will enable researchers, scholars, policy analysts and students to generate new research ranging from a single transit station area to entire metropolitan areas.

Is the research groundbreaking?

We have pioneered the genre of research that associates development outcomes with respect to different transit systems across the nation. This report updates and expands that research, bringing it through the post-Great Recession period. There are many surprises which are noted in the Executive Summary and detailed throughout the report.

Will it advance the state of the art or practice?

This report advances the state of the art of research by updating and expanding upon prior pioneering work and by making the database freely available through NITC.

How might this project distinguish NITC?

Prior work led by Nelson—Do TODs Make a Difference? and National Study of BRT 
Development Outcomes_advanced NITC's mission at the national scale through webinars, press conferences, numerous presentations, and scholarly articles. This report expands upon that work and is anticipated to elevate the knowledge of practitioners, policy makers, researchers, students, and the informed public when it comes to advancing fixed-route transit systems in order to improve the mobility of people to build strong communities. 


\section{REFERENCES}

CTOD. 2011. Transit and Regional Economic Development. Chicago, IL: Center for TOD

Nelson, Arthur C. et al. 2013. Bus Rapid Transit and Economic Development. Journal of Public Transportation.

Nelson, Arthur C. 2015. National Study of BRT Development Outcomes. Portland, OR: National Institute for Transportation and Communities.

Nelson, Arthur C. et al. 2015a. Do TODs Make a Difference? Portland, OR: National Institute for Transportation and Communities.

Nelson, Arthur C. et al. 2015b. Office Rent Premiums with Respect to Distance from Light Rail Transit Stations in Dallas. Transportation Research Record.

Nelson, Arthur C. 2017a. The Effect of TODs on Jobs, Wages, People and Housing. Fordham Law Review.

Nelson, Arthur C. 2017b. Transit and Real Estate Rents. Transportation Research Record.

Petheram, Susan J., Arthur C. Nelson et al. 2014. Using the Real Estate Market to Establish Light Rail Station Catchment Areas: Case Study of Attached Residential Property Values in Salt Lake County with Respect to Light Rail Station Distance, Transportation Research Record. 
This page intentionally left blank. 



\subsection{THE LINK BETWEEN TRANSIT STATION PROXIMITY AND COMMERCIAL REAL ESTATE RENTS WITH IMPLICATIONS FOR TRANSIT AND LAND USE PLANNING}

\subsection{OVERVIEW}

There is a dearth of systematic research into the relationship between fixed guideway transit (FGT) systems such as light rail transit (LRT), bus rapid transit (BRT), streetcar transit (SCT) and commuter rail transit (CRT) with respect to real estate rents and transit station proximity. Although there are numerous case studies of individual systems in individual metropolitan areas, they focus mostly on a single property type. Those studies also vary in the type of data used, methodologies, and functional form specifications. In other words, research lacks a consistent cross-section approach to estimate variation in real estate rents between FGT systems and different types of real estate. Our paper seeks to close this gap in the literature.

This chapter presents cross-section regression analysis that uses CoStar, census, and GIS-derived location data in a common methodology to estimate the association between FGT station proximity and office, retail, and multifamily rents. In all, nearly 60 FGT systems serving more than 30 metropolitan areas are studied, which includes about 300,000 cases. Numerous variables are used to control for structural attributes, occupancy, socioeconomic characteristics, land use, location and other influences.

For the most part—with some surprising exceptions-real estate rents tend to rise the closer the property is to transit stations. There also appears to be a sorting that occurs between real estate types and transit station proximity, which is to be expected in the competition for locations nearest to transportation services.

Implications for fixed guideway transit system and land use planning are offered.

\subsection{INTRODUCTION}

America has gone through four fixed guideway transit (FGT) eras. The first is the streetcar era which flourished from the 1880s through the 1940s. To make way for automobiles, they were mostly dismantled from the end of WWII to about 1960. What remained were mostly heritage and tourist-dominated streetcars such as those seen in San Francisco, Philadelphia and New Orleans. Starting in 1892, heavy rail systems were constructed in many of the largest metropolitan areas with the last new system opening a century later in 1993.2 Though some new lines and stations have been added to these systems during the $21^{\text {st }}$ century, it would seem that heavy rail transit is not a preferred transit investment even among the largest metropolitan

2 See https://en.wikipedia.org/wiki/List_of_United_States_rapid_transit_systems_by_ridership. 
areas.3 While regional commuter rail systems have been serving major northeastern and Great Lakes metropolitan areas since the early 1900s, most commuter rail systems have been built since the 1970s. 4

Despite FGT systems operating in the US for more than a century, and most during the last half century, there has not been rigorous, systematic cross-section analysis of whether and the extent to which these systems influence the real estate market. This chapter helps close the gap in research. In particular, we apply hedonic regression to estimate the association between FGT station proximity and office, retail and multifamily rents. Our research question is simply:

Is there an association between commercial real estate rent (per square foot) and proximity to FGT stations holding other factors constant?

The chapter proceeds with the research approach followed by an assessment of how the real estate market appears to capitalize upon proximity to streetcar stations in the form of higher or lower rents. Implications for transit and associated land use planning are offered.

\subsection{RESEARCH APPROACH}

This section outlines our research approach including a review of relevant theory, research design, general model, functional form, study areas and specific model and data.

\subsubsection{Theory}

Conventional urban location theory developed by Alonso (1964), Mills (1964), and Muth (1967) — also known as the AMM theory_shows that where all jobs are in the central business district (CBD), the cost of transportation increases with respect to distance from the CBD at a declining rate. Transportation costs reduce land value as distance from the CBD increases. In the $\mathrm{CBD}$, where transportation costs are lowest, land prices are highest. Thus, there is competition for location near CBDs when the land use needs among competing office, retail, institutional, residential and other uses are considered. Only those land uses that generate the highest economic exchanges win the most central locations. Land uses that cannot compete for CBD locations are pushed outward to areas where they can outbid other land uses, a process called urban land use invasion and succession (Park, Burgess, McKenzie and Wirth. 1925).

As one relaxes constraints of the AMM monocentric city model, it is possible to imagine the same principles are at work only at smaller scales in a more distributed fashion (Hajrasouliha \& Hamidi 2017). In particular, rail transit stations can become localized versions of CBDs.

Accordingly, economic activities will bid up land prices close to rail transit stations; lower value activity moves away from stations to locations where they may outbid competing land uses.

3 See https://en.wikipedia.org/wiki/Bus_rapid_transit and https://en.wikipedia.org/wiki/List_of_rail_transit_systems_in_the_United_States.) 4 See https://en.wikipedia.org/wiki/List_of_suburban_and_commuter_rail_systems.) 
Dozens of studies show negative bid-rent gradients with respect to distance from rail transit stations, which suggests these local level outcomes. (See Higgins \& Kanaroglou 2016)

We apply theory to these small CBDs, called FGT station areas.

\subsubsection{Research Design}

We apply theory through a static, cross-section, quasi-experimental research design. That is, using one period of time, we test for the effect of FGT stations on real estate rents across multiple metropolitan areas with those systems, and individual ones. Though analysis is not causal, associations can be used as guidance for transit and land use planning purposes

\subsubsection{General Model}

Using these theoretical and research design foundations as a guide, we develop the following general model to test the theory. It is adapted from Nelson (2017):

$$
\mathbf{R}_{i}=\mathbf{f}\left(S_{i}, S_{E S}, P_{i}, U_{i}, L_{i}, D B_{i}, M_{i}\right)
$$

where:

$\mathbf{R}$ is the asking rent per square foot for property $i$;

$\mathbf{S}$ is the set of structural attributes of property $i$ including its architecture, mass, height, age and effective age, interior amenities, flow efficiencies and so forth;

SES is the set of socioeconomic characteristics of the vicinity of property $i$ such as population features, income, education;

$\mathbf{P}$ is a set of planning, zoning and other development restrictions applicable to property $i$;

$\mathbf{U}$ is a set of measures of urban form of the vicinity of property $i$ such as the nature of surrounding land uses, terrain, physical amenities (such as parks), street characteristics and related;

$\mathbf{L}$ is a set of location attributes of property $i$ such as distance to downtown and other activity centers, and distance to nearest major highways including freeway/expressway ramps;

DB is the distance from the closest point of a parcel to the centroid of the FGT station centroid; and

$\mathbf{M}$ is a set of metropolitan area controls. As metropolitan area conditions and markets vary between them, identifying the location of property $i$ within its respective market helps control for metropolitan-specific influences. 


\subsubsection{Functional Form}

The AMM theory posits that land value will decline with distance from the CBD or other high activity nodes. Linear, semi-log, and double-log functional forms are the dominant forms reported in literature (Higgins and Kanaroglou 2016).

The linear functional form assumes a straight line deduction in property value with respect to distance away from a node, such as a transit station.

The semi-log functional form — where the dependent variable is logged — estimates the percent change in value associated with a unit change in an independent variable.

The double-log functional form generates elasticities - continuously measured variables on both sides of the equation are logged, although categorical and binary variables are not.

In our view, none of these functional forms are highly useful to transit and land use planners who need to know how to arrange transit investments and land use policies to maximize the economic benefits of transit station proximity. Lacking guidance from studies using these conventional functional forms, planners tend to settle on quarter-mile and half-mile planning areas around stations, with very little empirical justification.

A less-used approach, the quadratic functional form, is specified such that the linear distance term is squared and both terms are included in analysis. It has the potential to pinpoint the break point in the transit station distance curve. In the context of FGT stations, the concern is that rail stations themselves can be nuisances such that real estate values and rents may be dampened very near them. As Nelson and McClesky (1990) theorize, the market capitalizes both positive amenity effects of rail station proximity as well as negative amenity effects, for instance those associated with noise (such as dispatching broadcasts at station platforms), and congestion (such as when vehicles use park and ride lots during peak hours) (Nelson 1992). So long as positive amenity effects outweigh negative ones, the bid-rent gradient will slope downward and away from rail transit stations. However, in theory it is possible for negative amenity effects to outweigh positive ones. But quadratic functional forms may not be very useful either, especially if both signs are in the same direction (increasing or decreasing value at a faster rate with respect to distance). Even where signs are different, the smaller the second term relative to the first the flatter the slope. For example, if the second term above is 1.00 , the minima is 10 miles which may not be very useful to planners crafting plans around stations.

Distance bands offer a practical middle ground between knowing whether and the extent to which real estate markets respond to transit stations within discrete distances of FGT stations. They also provide statistical significance test results for each band separately. Unfortunately, most distance-band studies use only one-quarter or one-half mile distance bands,

(see Higgins and Kanaroglou 2016) or occasionally two bands (see Nelson 2017). But that assumes all relevant interactions which are useful for planners to know occur only within those distance bands, and that those bands apply to all transit modes in all metropolitan areas. 
Following Hibberd et al., (2018) and Nelson and Hibberd (2019) this article expands on and applies the distance band concept, described in more detail below.

\subsubsection{Study Area}

Given that literature has not reported rigorous research into the relationship between FGT station proximity and commercial rents such as for office, multifamily and retail activities, we do so here. In particular, we apply the general model with various functional forms to the following FGT modes and these metropolitan areas. Our analysis is limited to the counties within which these FGT systems operate-not all counties in their metropolitan areas. This is shown in Table 2.1 .

Table 2.1: Metropolitan Area Fixed Guideway Transit Systems

\begin{tabular}{c|c|c|c}
\hline $\begin{array}{c}\text { Light Rail Transit } \\
\text { Metros }\end{array}$ & $\begin{array}{c}\text { Bus Rapid Transit } \\
\text { Metros }\end{array}$ & $\begin{array}{c}\text { Streetcar Transit } \\
\text { Metros }\end{array}$ & $\begin{array}{c}\text { Commuter Rail Transit } \\
\text { Metros }\end{array}$ \\
\hline Buffalo & Cleveland & Atlanta & Albuquerque-Santa Fe \\
\hline Charlotte & Eugene-Springfield & Cincinnati & Austin \\
\hline Cleveland & Kansas City & Dallas & Dansas City \\
\hline Dallas & Las Vegas & Little Rock & Miami \\
\hline Denver & Minneapolis-St. Paul & New Orleans & Minneapolis-St. Paul \\
\hline Houston & Nashville & Portland & Nashville \\
\hline Minneapolis-St. Paul & Phoenix & Salt Lake City & Orlando \\
\hline Norfolk & Pittsburgh & Seattle & Sortland \\
\hline Phoenix & Reno & Tacoma & San Diego \\
\hline Pittsburgh & Salt Lake & Tucson & San Jose \\
\hline Portland & San Diego & Washington, DC & Seattle-Tacoma \\
\hline Sacramento & San Jose & & Washington, DC \\
\hline Salt Lake City & Seattle & & \\
\hline San Diego & & &
\end{tabular}

Specification details are reviewed next.

\subsubsection{Specific Model and Data}

We operationalize the general model dimensions and functional form here. Notably, we report the statistical association between rent per square foot for office, retail and multifamily properties with respect to FGT station proximity using one-eighth mile distance bands, holding other factors constant.

$\mathbf{R}$ is the asking rent per square foot for property $i$ reported by CoStar during 2017. These include all properties with space for rent from among office, retail, and multifamily real estate projects. 5

5 Normally, statistical analysis is applied to samples of a universe. In this case, the study includes the universe of all properties reported by CoStar. As CoStar data come from real estate 
By logging the dependent variable, the semi-log model allows for coefficients to be interpreted as the percent change in rent attributable to a one unit change in an independent variable such as an individual distance band.

$\mathbf{S}$ is the bundle of structure attributes for property $i$ reported by CoStar. This includes occupancy characteristics noted below. For all properties, this includes:

Gross leasable area in building square feet with the expectation that there will be a positive association between building area and rent because larger buildings presumably include more amenities than smaller ones.

Effective year built which is the later of the year of construction or the year of renovation as reported by CoStar with the expectation that newer buildings will command more rent than older ones.

Vacancy rate with the expectation that the higher the vacancy rate the lower the rent. However, this may not always be the case as high demand markets could result in high vacancy rates as owners wait for higher paying tenants. Accordingly, signs may not be predictable especially considering that the study area is comprised of stable to rapidly growing central counties.

For office properties, structural attributes also include binary variables indicating whether the building is considered Class $A$ or Class $B$ with the expectation that Class A rents will be higher than Class B which will in turn be higher than Class C, which is the referent building class.

The number of Stories is also included with the expectation that the taller the building the higher the mean rent. However, for retail, Stories are excluded because of scant variation among retail structures.

Retail structures are also coded by whether or not $(1,0)$ they are classified as Power Center, Neighborhood Center, Community Center, Regional Mall, Lifestyle Center and Outlet Mall. As there is no literature allowing us to predict signs of association between these activities and our referent, Strip Centers, we do not predict directions of association.

For multifamily facilities, occupancy restrictions are included, notably Senior or Student housing with Market Rate housing being the referent. The expectation is that relative to Market Rate multifamily units, rents for Student housing will be lower but rents for Senior housing will be higher.

brokerages participating in its network, the data exclude non-participating brokerages or entities and properties not for rent such as owner-occupied properties. 
The SES vector is comprised of Median Household Income from the five-year sample of the 2016 American Community Survey (ACS) for the block group within which a CoStar property is located, for which a positive association is expected with respect to rent (see Xiao 2016).

The attributes for the $\mathbf{P}$ vector are missing because resources did not allow us to identify planning and zoning conditions applied to the nearly 20,000 properties in our data base.

Two variables comprise the $\mathbf{U}$ dimension. The first is our calculation of jobs-housing balance, which is the number of jobs in a census block group (BG) from the Longitudinal EmploymentHousehold Dynamics database divided by the number of residents of labor force age (being 15 to 65 years old) which we call Workers per Labor Force. The higher the ratio the more people work in the BG relative to those who live there. As such, more pressure is put on rents so we expect a positive association (see Stoker and Ewing 2014).

The second variable, Entropy, is patterned after Ewing and Hamidi (2014) who use an entropy calculation as a proxy for land use mix. The greater the mix, the higher rents should be because of efficiencies gained in the interaction between land uses.

Two variables comprise the $\mathbf{L}$ dimension. The first location control is Distance from Downtown for which a negative association is expected based on the AMM theory. Using Google Earth, we identified the central most point of each downtown. The second location control is Distance from Freeway which is defined as the nearest freeway or expressway ramp. Because freeway ramps can be considered nuisances in addition to being an accessibility benefit, no signs of association are predicted.

DB is defined as the location of the subject property within one-eighth mile distance bands of the nearest FGT station outward to two miles. We use closest distance, calling it the "front door," assuming that structures on parcels will orient themselves to be close to transit stations. We also measure straight line distance; future research will measure network distance. The two-mile distance was used to assure a maximum reasonable distance for estimating distance band effects based on work by Nelson et al. (2015) for Dallas office rental market LRT effects (about 1.75 miles) and Petheram et al. (2013) for the Salt Lake County multifamily building LRT assessed value effects (about 1.25 miles). For instance, in the equations,

$>0.125-<=0.250$ mile

means property $i$ is in the distance band that is greater than 0.125 miles but less than or equal to 0.250 miles from the nearest street car transit station.

While a positive association is expected between DBs and FGT stations, negative associations can signal externality effects noted above. For instance, areas very near stations may have nuisances such as traffic, noise, and poor urban design that offset positive effects of proximity. But DBs farther away may have positive coefficients. Finally, the DB approach allows us to estimate how far away from transit stations the market values proximity, which is important for transit and land use planning. In the regression results reported below, significant DB coefficients - where $p<0.10$ of the two-tailed test since direction of association is theorized - are noted in bold red. Theory allows for both positive and negative signs, with negative signs indicating localized nuisances 
associated with FGT stations and nearby land uses become negative externalities internalized as lower rent.

Further, for presentation and illustration purposes, we allow for a DB skip between significant DB coefficients. For instance, if DB coefficients are significant through 0.325 mile, but not in the next DB for 0.500 mile, but the next one is significant, to 0.625 , we highlight the coefficients for the significant DBs but not any others. Again for presentation and illustration purposes, we do not highlight significant coefficients of DBs if there are two or more DBs with insignificant coefficients between them.

The $\mathbf{M}$ vector is comprised of the individual metropolitan counties within which the FGT systems operate (see Table 1). As these are controls which account for idiosyncrasies of metropolitan markets, no direction of associations is predicted.

Our models include many times more data than is used in most prior studies (see Higgins and Kanaroglou for comparison). While we have no a priori expectations of goodness of fit outcomes, literature suggests that ordinary least squares hedonic (regression) analysis can explain about one fifth to three quarters of the variation in the observed rent for cases.

Some analysts may be preoccupied with achieving high levels of regression model explanation. Yet, too many variables can lead to over-specification. It is best to emphasize the variables most relevant to the question, with some related controls sufficient to avoid serious omitted variable bias (a form of endogeneity) in the model. Our model is based on both theory and a large body of prior empirical work.

Table 2.2 summarizes the variables, source of data, and directions of association. 
Table 2.2: Variables, Data Sources, and Predicted Association with Respect to Rent

\begin{tabular}{|c|c|c|}
\hline Structure Controls & Data Source & Predicted Sign \\
\hline Gross Leasable Area & CoStar & + \\
\hline Class A Office & CoStar & + \\
\hline Class B Office & CoStar & + \\
\hline Stories & CoStar & + \\
\hline Effective Year Built & CoStar & + \\
\hline Vacancy Rate & CoStar & - \\
\hline Power Center & CoStar & na \\
\hline Neighborhood & CoStar & na \\
\hline Community & CoStar & na \\
\hline Regional & CoStar & na \\
\hline Lifestyle & CoStar & na \\
\hline Outlet & CoStar & na \\
\hline \multicolumn{3}{|l|}{ Occupancy Control } \\
\hline Senior & CoStar & na \\
\hline Student & CoStar & na \\
\hline \multicolumn{3}{|l|}{ Socioeconomic Control } \\
\hline Median Household Income & Census ACS & + \\
\hline \multicolumn{3}{|l|}{ Land Use Mix Controls } \\
\hline Workers per Labor Force & LEHD, ACS & + \\
\hline Entropy & LEHD & + \\
\hline \multicolumn{3}{|l|}{ Location Controls } \\
\hline Distance Downtown Center & Computed & + \\
\hline Distance Freeway Ramp & Computed & $+/-$ \\
\hline \multicolumn{3}{|l|}{ Distance Band } \\
\hline 1/8 mile bands to 2.0 miles & Computed &,$++/-$ \\
\hline
\end{tabular}

We present results next followed by implications for transit and land use planning. 


\subsection{RESULTS AND DISCUSSION}

Tables 2.3 through 2.6 report regression results for office, multifamily and retail properties for light rail transit (LRT), bus rapid transit (BRT), streetcar transit (SCT) and commuter rail transit (CRT) systems respectively. Figures 2.1 through 2.4 illustrate these effects. Table 2.7 A series of tables in the appendix report regression equations for each metropolitan area for office, multifamily and retail structures, using information provided by CoStar.

The coefficients of determination are modest, explaining from about 30 percent to more than 60 percent of the variation in rents. For the most part, control variables have the correct signs and reasonable magnitudes. Notably, the structure variables for which directions are predicted along with the socioeconomic control performed as expected. The land use mix variables performed mostly as expected although with some negative associations with respect to entropy. The location variables performed as expected with some negative associations with respect to freeway ramp distance, as anticipated.

Of interest here is performance of the DB variables overall. We address each mode separately. With respect to LRT systems, station proximity appears to influence (see Table 2.3 and Figure 2.1):

- Office rents significantly only in the first band, to 0.125 mile;

- Multifamily rents significantly to about 1.500 miles; and

- Retail rents significantly to about 1.125 miles.

Results for offices are surprising since numerous studies of individual systems suggest office rent premiums to nearly a mile (in Minneapolis according to Ko and Cao 2013) or nearly two miles (Dallas according to Nelson et al. 2015). However, Appendix Table A1 sheds some light on this. In six of the 17 metropolitan areas with LRT systems there were no statistically significant effects, while in four there were statistically significant negative associations, beyond one mile in two cases. Indeed, ongoing research shows that the placement, and especially design, of LRT stations helps explain ambiguous and especially negative associations. Despite controlling for individual metropolitan areas, the weight of these ambiguous and negative results are sufficient to weaken statistical outcomes based on all 15,752 cases. Our future work will focus on the planning and design features that may lead to ambiguous, negative, and positive associations between office rents and LRT station proximity.

On the other hand, outcomes with respect to multifamily and retail rents are as expected. As seen in Appendix Table A2, there were positive associations between multifamily rent and LRT station proximity in nearly all metropolitan areas (with ambiguous results in only two and negative results in another one). While there were ambiguous results with respect to retail rents and LRT station proximity in eight metropolitan areas and negative results in two, results for the others were robust often beyond a mile in the others.

A key finding from our LRT analysis is that there are robust associations between multifamily rents and LRT station proximity beyond one mile across many metropolitan areas and all 
metropolitan areas as a whole. While LRT station location and design may affect interactions between LRT stations and office and retail commercial activities, this does not seem to be the case with respect to multifamily structures.

With respect to BRT systems, station proximity appears to influence (see Table 2.4 and Figure 2.2):

- Office rents significantly to about 0.500 mile;

- Multifamily rents significantly to about 1.250 miles; and

- $\quad$ Retail rents significantly to about 0.375 mile.

Notably, in the overall model, none of the commercial real estate types had a significant association with respect to BRT station proximity in the first band to 0.125 mile. We surmise that BRT station location and design may have nuisance effects that offset proximity effects. This is clearly an area of future research into BRT station location and design. Also, notably, multifamily rent premiums extend the longest distance, though they tend to rise away from BRT stations. This is another signal that BRT station location and design may not be maximizing advantages of transit access.

Inspection of Appendix Tables A4, A5 and A6 indicate ambiguous associations in about half of the metropolitan areas and negative associations in a few. Otherwise, positive associations occur especially among multifamily structures. Preliminary research indicates that BRT stations vary considerably by construction (some are only a conventional bus shelter while others are nearly fully enclosed with high-tech amenities) and location (some are amidst underinvested areas but others appear to be contributing to reinvestment).

With respect to SCT systems, station proximity appears to influence (see Table 2.5 and Figure 2.3):

- $\quad$ Office rents significantly to about 0.500 mile;

- Multifamily rents significantly to perhaps 2.000 miles; and

- $\quad$ Retail rents significantly to about 0.875 mile.

Of all the FGT systems evaluated for their influence on rents, SCT systems performed best overall. This is probably not surprising given that SCT systems operate mostly in highly developed downtown or near downtown settings, and in physically attractive areas. That the multifamily rent performance extends perhaps two miles from SCT stations does not suggest riders walk that distance to access streetcars. The reason may be the density of access opportunities through feeder bus lines, bicycles and such. 
With respect to CRT systems, station proximity appears to positively influence (see Table 2.6 and Figure 2.4):

- $\quad$ Office rents significantly to about 1.000 mile;

- Multifamily rents significantly to perhaps 2.000 miles; and

- Retail rents significantly to about 0.125 mile.

This is a surprise. Conventional wisdom suggests that real estate markets eschew proximity to CRT stations because they typically share tracks with commercial rail freight operations and stations tend to be set in industrial areas. Indeed, based on crude half-mile distance band studies in the past, Higgins and Kanaroglou review shows mostly negative or ambiguous results. On the other hand, many of those studies date from nearly two or more decades ago so improvements in CRT locations and designs may account for positive results. Moreover, for those living in suburban areas who work in downtown or at nodes along CRT lines, commuter trains reduce their commute and even offer them productive time to work, and relaxing time coming home. This seems to be borne out in the associated appendix tables for several CRT systems individually.

For more detailed data, we refer the reader to the Data Appendix for the Link between Transit Station Proximity and Real Estate Rents.

\subsection{IMPLICATIONS FOR TRANSIT AND LAND USE PLANNING}

There are three key lessons offered in this article.

First, hedonic regression analysis of the association between commercial rents, and real estate values generally, may benefit from using a fine-grained distance band functional form. It may be the only functional form that can lead to easily interpretable results for transit and land use planners.

Second, we are surprised overall by the weak results relating to the association between FGT station proximity and office rents. Yet, in looking at the performance of individual metropolitan areas combined with emerging studies of the location and design of FGT stations, we should not be surprised. Many stations in San Diego, San Jose, Portland, Sacramento and others are either elevated above freeways or highways, tucked into areas where development around them is virtually impossible, or may otherwise be attractive to the market but for locally nonresponsive planning and zoning. Although this study did not include an assessment of the association between FGT station location and design on commercial rents, we outline an approach for future research in Chapter 5.

A third surprise for us is the resilience of multifamily residential rents. Multifamily rent premiums extend the longest distances from LRT stations and are more robust than office or retail rents, even in many metropolitan areas where office and retail responsiveness to station proximity is ambiguous or negative.

Most LRT, BRT and SCT systems are less than 20 years old and many are less than 10 years old. There is much to learn about how the market responds to them. Although CRT systems have 
been operating in the Northeast and Great Lakes for the better part of a century, those in our study are also less than 20 years old and many are less than 10 years old. Continual monitoring of how FGT systems add value to the real estate market — through rents, for example-is needed to guide the next generation of transit and land use planning. As these systems are upgraded, lessons learned from market responsiveness can help guide those efforts to maximize real estate market responsiveness. 
Table 2.3: Commercial Rent Regression Equations with Respect to Light Rail Transit Station Proximity by Distance Band

\begin{tabular}{|c|c|c|c|c|c|}
\hline \multicolumn{2}{|c|}{$\begin{array}{c}\text { Office Rents with Respect to } \\
\text { LRT Station Proximity }\end{array}$} & \multicolumn{2}{|c|}{$\begin{array}{c}\text { Apartment Rents with Respect to } \\
\text { LRT Station Proximity }\end{array}$} & \multicolumn{2}{|c|}{$\begin{array}{l}\text { Retail Rents with Respect to } \\
\text { LRT Station Proximity }\end{array}$} \\
\hline Variables & Office & Variables & Multifamily & Variables & Retail \\
\hline Constant & 1.814 & Constant & -3.483 & Constant & -0.871 \\
\hline Structure Controls & & Structure Controls & & Structure Controls & \\
\hline Gross Leasable Area & $-1.456 \mathrm{E}-007$ & Gross Leasable Area & 2.897E-007 & Gross Leasable Area & $-7.867 \mathrm{E}-007$ \\
\hline Class A Office & 0.366 & Average Unit Size & -0.001 & Average Unit Size & 0.002 \\
\hline Class B Office & 0.118 & Stories & $\mathbf{0 . 0 2 5}$ & Vacancy Rate & 0.000 \\
\hline Stories & 0.007 & Effective Year Built & 0.002 & Power Center & 0.176 \\
\hline Effective Year Built & 0.000 & Vacancy Rate & 0.004 & Neighborhood & -0.027 \\
\hline \multirow[t]{4}{*}{ Vacancy Rate } & -0.001 & Occupancy Control & & Community & $\mathbf{0 . 0 5 7}$ \\
\hline & & Senior & -0.054 & Regional & 0.328 \\
\hline & & Student & -0.028 & Lifestyle & 0.264 \\
\hline & & & & Outlet & 0.071 \\
\hline Socioeconomic Control & & Socioeconomic Control & & Socioeconomic Control & \\
\hline $\begin{array}{l}\text { Median Household } \\
\text { Income }\end{array}$ & 1.319E-006 & Median Household Income & 2.848E-006 & Median Household Income & 2.672E-006 \\
\hline Land Use Mix Controls & & Land Use Mix Controls & & Land Use Mix Controls & \\
\hline Workers per Labor Force & 0.001 & Workers per Labor Force & 0.002 & Workers per Labor Force & 0.001 \\
\hline Entropy & -0.040 & Entropy & 0.083 & Entropy & 0.006 \\
\hline Location Controls & & Location Controls & & Location Controls & \\
\hline $\begin{array}{l}\text { Distance Downtown } \\
\text { Center }\end{array}$ & $-5.764 \mathrm{E}-007$ & Distance Downtown Center & $-6.631 E-007$ & Distance Downtown Center & $-1.223 E-006$ \\
\hline Distance Freeway Ramp & $-1.298 E-006$ & Distance Freeway Ramp & $-1.126 E-006$ & Distance Freeway Ramp & -8.602E-007 \\
\hline Distance Band & & Distance Band & & Distance Band & \\
\hline$<=0.125$ mile & 0.017 & $<=0.125$ mile & 0.048 & $<=0.125$ mile & 0.083 \\
\hline$>0.125-<=0.250$ mile & -0.002 & $>0.125-<=0.250$ mile & 0.072 & $>0.125-<=0.250$ mile & 0.058 \\
\hline$>0.250-<=0.375$ mile & -0.005 & $>0.250-<=0.375$ mile & 0.045 & $>0.250-<=0.375$ mile & 0.031 \\
\hline$>0.370-<=0.500$ mile & 0.008 & $>0.370-<=0.500$ mile & 0.057 & $>0.370-<=0.500$ mile & 0.026 \\
\hline$>0.500-<=0.625$ mile & 0.013 & $>0.500-<=0.625$ mile & 0.050 & $>0.500-<=0.625$ mile & 0.036 \\
\hline$>0.625-<=0.750$ mile & -0.016 & $>0.625-<=0.750$ mile & 0.061 & $>0.625-<=0.750$ mile & 0.041 \\
\hline$>0.750-<=0.875$ mile & -0.029 & $>0.750-<=0.875$ mile & 0.046 & $>0.750-<=0.875$ mile & 0.049 \\
\hline$>0.875-<=1.000$ mile & -0.023 & $>0.875-<=1.000$ mile & 0.055 & $>0.875-<=1.000$ mile & 0.037 \\
\hline$>1.000-<=1.125$ mile & -0.023 & $>1.000-<=1.125$ mile & 0.034 & $>1.000-<=1.125$ mile & 0.031 \\
\hline$>1.125-<=1.250$ mile & -0.027 & $>1.125-<=1.250$ mile & 0.028 & $>1.125-<=1.250$ mile & 0.003 \\
\hline
\end{tabular}




\begin{tabular}{|c|c|c|c|c|c|}
\hline \multicolumn{2}{|c|}{$\begin{array}{l}\text { Office Rents with Respect to } \\
\text { LRT Station Proximity }\end{array}$} & \multicolumn{2}{|c|}{$\begin{array}{l}\text { Apartment Rents with Respect to } \\
\text { LRT Station Proximity }\end{array}$} & \multicolumn{2}{|c|}{$\begin{array}{l}\text { Retail Rents with Respect to } \\
\text { LRT Station Proximity }\end{array}$} \\
\hline$>1.250-<=1.375$ mile & -0.029 & $>1.250-<=1.375$ mile & 0.021 & $>1.250-<=1.375$ mile & 0.001 \\
\hline$>1.370-<=1.500$ mile & -0.002 & $>1.370-<=1.500$ mile & 0.015 & $>1.370-<=1.500$ mile & 0.024 \\
\hline$>1.500-<=1.625$ mile & -0.095 & $>1.500-<=1.625$ mile & 0.003 & $>1.500-<=1.625$ mile & 0.036 \\
\hline$>1.625-<=1.750$ mile & -0.064 & $>1.625-<=1.750$ mile & 0.014 & $>1.625-<=1.750$ mile & -0.012 \\
\hline$>1.750-<=1.875$ mile & -0.095 & $>1.750-<=1.875$ mile & 0.002 & $>1.750-<=1.875$ mile & 0.036 \\
\hline$>1.875-<=2.000$ mile & 0.003 & $>1.875-<=2.000$ mile & 0.013 & $>1.875-<=2.000$ mile & 0.057 \\
\hline Model Performance & & Model Performance & & Model Performance & \\
\hline Cases & 15,752 & Cases & 28,311 & Cases & 8,644 \\
\hline $\mathrm{R} 2$, adjusted & 0.386 & $\mathrm{R} 2$, adjusted & 0.577 & $\mathrm{R} 2$, adjusted & 0.282 \\
\hline F-ratio & 231.054 & F-ratio & 880.314 & F-ratio & 151.791 \\
\hline Descriptive Statistics & & Descriptive Statistics & & Descriptive Statistics & \\
\hline Rent Square Foot/Year & $\$ 21.68$ & Rent Square Foot/Year & $\$ 1.44$ & Rent Square Foot/Year & $\$ 20.87$ \\
\hline
\end{tabular}




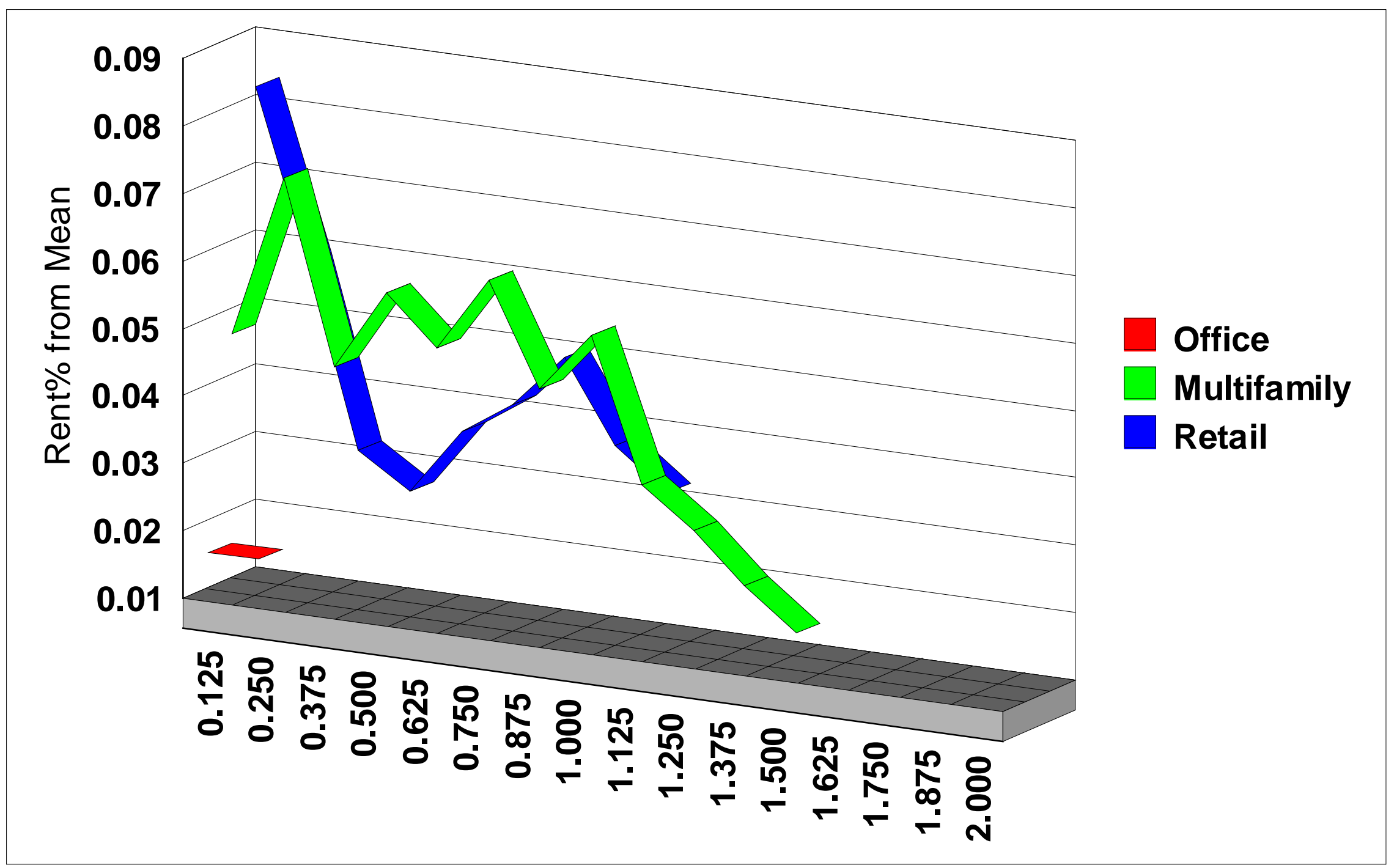

Figure 2.1: Illustration of Commercial Rents with Respect to Light Rail Transit Station Proximity to 2.00 Miles 
Table 2.4: Commercial Rent Regression Equations with Respect to Bus Rapid Transit Station Proximity by Distance Band

\section{Office Rents with Respect to BRT Station Proximity}

\begin{tabular}{|c|c|}
\hline Variable & All Cases \\
\hline Constant & 0.004 \\
\hline \multicolumn{2}{|l|}{ Structural Controls } \\
\hline $\begin{array}{l}\text { Gross Leasable } \\
\text { Area }\end{array}$ & $\begin{array}{r}1.741 \mathrm{E}- \\
008\end{array}$ \\
\hline Class A Office & 0.419 \\
\hline Class B Office & 0.143 \\
\hline Stories & 0.005 \\
\hline $\begin{array}{l}\text { Effective Year } \\
\text { Built }\end{array}$ & 0.001 \\
\hline Vacancy Rate & -0.001 \\
\hline & \\
\hline & \\
\hline $\begin{array}{l}\text { Socioeconomic } \\
\text { Control }\end{array}$ & \\
\hline $\begin{array}{l}\text { Median } \\
\text { Household Income }\end{array}$ & $\begin{array}{r}1.339 \mathrm{E}- \\
006\end{array}$ \\
\hline Land Use Controls & \\
\hline $\begin{array}{l}\text { Workers per } \\
\text { Labor Force }\end{array}$ & 0.001 \\
\hline Entropy & -0.030 \\
\hline Location Controls & \\
\hline $\begin{array}{l}\text { Distance } \\
\text { Downtown Center }\end{array}$ & $\begin{array}{r}-1.744 E- \\
007\end{array}$ \\
\hline $\begin{array}{l}\text { Distance Freeway } \\
\text { Ramp }\end{array}$ & $\begin{array}{r}-2.654 \mathrm{E}- \\
006 \\
\end{array}$ \\
\hline Distance Bands & \\
\hline$<=0.125$ mile & 0.016 \\
\hline $\begin{array}{l}>0.125-<=0.250 \\
\text { mile }\end{array}$ & 0.065 \\
\hline $\begin{array}{l}>0.250-<=0.375 \\
\text { mile }\end{array}$ & 0.065 \\
\hline $\begin{array}{l}>0.370-<=0.500 \\
\text { mile }\end{array}$ & 0.053 \\
\hline $\begin{array}{l}>0.500-<=0.625 \\
\text { mile }\end{array}$ & -0.017 \\
\hline $\begin{array}{l}>0.625-<=0.750 \\
\text { mile }\end{array}$ & -0.022 \\
\hline $\begin{array}{l}>0.750-<=0.875 \\
\text { mile }\end{array}$ & 0.054 \\
\hline $\begin{array}{l}>0.875-<=1.000 \\
\text { mile }\end{array}$ & -0.030 \\
\hline
\end{tabular}

Apartment Rents with Respect

to

BRT Station Proximity

\begin{tabular}{|c|c|c|c|}
\hline & \multirow{2}{*}{\multicolumn{2}{|c|}{ All Cacos }} \\
\hline Variable & All Cases & & All Cases \\
\hline Constant & -3.771 & Constant & -4.454 \\
\hline Structural Controls & & $\begin{array}{l}\text { Structural } \\
\text { Controls }\end{array}$ & \\
\hline $\begin{array}{l}\text { Gross Leasable } \\
\text { Area }\end{array}$ & $\begin{array}{r}3.511 E- \\
007\end{array}$ & $\begin{array}{l}\text { Gross Leasable } \\
\text { Area }\end{array}$ & $\begin{array}{r}-6.333 E- \\
007 \\
\end{array}$ \\
\hline Average Unit Size & $\begin{array}{l}-0.001 \\
\end{array}$ & Stories & 0.054 \\
\hline Stories & 0.025 & $\begin{array}{l}\text { Effective Year } \\
\text { Built }\end{array}$ & 0.004 \\
\hline Effective Year Built & 0.002 & Vacancy Rate & 0.000 \\
\hline Vacancy Rate & 0.004 & Power Center & 0.233 \\
\hline \multicolumn{2}{|c|}{ Occupancy Restriction Controls } & $\begin{array}{l}\text { Neighborhood } \\
\text { Center }\end{array}$ & 0.010 \\
\hline Senior & -0.093 & Community Center & 0.096 \\
\hline Student & 0.004 & Regional Mall & 0.262 \\
\hline & & Lifestyle Center & 0.402 \\
\hline & & Outlet Center & 0.556 \\
\hline $\begin{array}{l}\text { Socioeconomic } \\
\text { Control }\end{array}$ & & $\begin{array}{l}\text { Socioeconomic } \\
\text { Control }\end{array}$ & \\
\hline $\begin{array}{l}\text { Median Household } \\
\text { Income }\end{array}$ & $\begin{array}{r}2.684 \mathrm{E}- \\
006\end{array}$ & $\begin{array}{l}\text { Median Household } \\
\text { Income }\end{array}$ & $\begin{array}{r}3.261 E- \\
006\end{array}$ \\
\hline Land Use Controls & & Land Use Controls & \\
\hline $\begin{array}{l}\text { Workers per Labor } \\
\text { Force }\end{array}$ & 0.002 & $\begin{array}{l}\text { Workers per Labor } \\
\text { Force }\end{array}$ & 0.002 \\
\hline Entropy & 0.070 & Entropy & -0.017 \\
\hline Location Controls & & Location Controls & \\
\hline $\begin{array}{l}\text { Distance Downtown } \\
\text { Center }\end{array}$ & $\begin{array}{r}-6.569 \mathrm{E}- \\
007 \\
\end{array}$ & $\begin{array}{l}\text { Distance } \\
\text { Downtown Center }\end{array}$ & $\begin{array}{r}-1.112 E- \\
006 \\
\end{array}$ \\
\hline $\begin{array}{l}\text { Distance Freeway } \\
\text { Ramp }\end{array}$ & $\begin{array}{r}-2.186 E- \\
006 \\
\end{array}$ & $\begin{array}{l}\text { Distance Freeway } \\
\text { Ramp }\end{array}$ & $\begin{array}{r}-1.182 E- \\
006 \\
\end{array}$ \\
\hline Distance Bands & & Distance Bands & \\
\hline$<=0.125$ mile & 0.005 & $<=0.125$ mile & 0.009 \\
\hline $\begin{array}{l}>0.125-<=0.250 \\
\text { mile }\end{array}$ & -0.025 & $\begin{array}{l}>0.125-<=0.250 \\
\text { mile }\end{array}$ & 0.140 \\
\hline $\begin{array}{l}>0.250-<=0.375 \\
\text { mile }\end{array}$ & 0.009 & $\begin{array}{l}>0.250-<=0.375 \\
\text { mile }\end{array}$ & 0.085 \\
\hline $\begin{array}{l}>0.370-<=0.500 \\
\text { mile }\end{array}$ & 0.019 & $\begin{array}{l}>0.370-<=0.500 \\
\text { mile }\end{array}$ & -0.030 \\
\hline $\begin{array}{l}>0.500-<=0.625 \\
\text { mile }\end{array}$ & 0.021 & $\begin{array}{l}>0.500-<=0.625 \\
\text { mile }\end{array}$ & 0.010 \\
\hline $\begin{array}{l}>0.625-<=0.750 \\
\text { mile }\end{array}$ & 0.031 & $\begin{array}{l}>0.625-<=0.750 \\
\text { mile }\end{array}$ & 0.015 \\
\hline $\begin{array}{l}>0.750-<=0.875 \\
\text { mile }\end{array}$ & 0.024 & $\begin{array}{l}>0.750-<=0.875 \\
\text { mile }\end{array}$ & 0.060 \\
\hline $\begin{array}{l}>0.875-<=1.000 \\
\text { mile }\end{array}$ & 0.036 & $\begin{array}{l}>0.875-<=1.000 \\
\text { mile }\end{array}$ & 0.003 \\
\hline
\end{tabular}

Retail Rents with Respect to BRT Station Proximity 


\begin{tabular}{|c|c|c|c|c|c|}
\hline \multicolumn{2}{|c|}{$\begin{array}{l}\text { Office Rents with Respect to } \\
\text { BRT Station Proximity }\end{array}$} & \multicolumn{2}{|c|}{$\begin{array}{c}\text { Apartment Rents with Respect } \\
\text { to } \\
\text { BRT Station Proximity }\end{array}$} & \multicolumn{2}{|c|}{$\begin{array}{l}\text { Retail Rents with Respect to } \\
\text { BRT Station Proximity }\end{array}$} \\
\hline $\begin{array}{l}>1.000-<=1.125 \\
\text { mile }\end{array}$ & -0.107 & $\begin{array}{l}>1.000-<=1.125 \\
\text { mile }\end{array}$ & 0.009 & $\begin{array}{l}>1.000-<=1.125 \\
\text { mile }\end{array}$ & 0.051 \\
\hline $\begin{array}{l}>1.125-<=1.250 \\
\text { mile }\end{array}$ & -0.078 & $\begin{array}{l}>1.125-<=1.250 \\
\text { mile }\end{array}$ & 0.003 & $\begin{array}{l}>1.125-<=1.250 \\
\text { mile }\end{array}$ & -0.016 \\
\hline $\begin{array}{l}>1.250-<=1.375 \\
\text { mile }\end{array}$ & -0.045 & $\begin{array}{l}>1.250-<=1.375 \\
\text { mile }\end{array}$ & -0.017 & $\begin{array}{l}>1.250-<=1.375 \\
\text { mile }\end{array}$ & -0.035 \\
\hline $\begin{array}{l}>1.370-<=1.500 \\
\text { mile }\end{array}$ & -0.060 & $\begin{array}{l}>1.370-<=1.500 \\
\text { mile }\end{array}$ & -0.010 & $\begin{array}{l}>1.370-<=1.500 \\
\text { mile }\end{array}$ & -0.049 \\
\hline $\begin{array}{l}>1.500-<=1.625 \\
\text { mile }\end{array}$ & -0.091 & $\begin{array}{l}>1.500-<=1.625 \\
\text { mile }\end{array}$ & 0.022 & $\begin{array}{l}>1.500-<=1.625 \\
\text { mile }\end{array}$ & 0.053 \\
\hline $\begin{array}{l}>1.625-<=1.750 \\
\text { mile }\end{array}$ & -0.104 & $\begin{array}{l}>1.625-<=1.750 \\
\text { mile }\end{array}$ & 0.023 & $\begin{array}{l}>1.625-<=1.750 \\
\text { mile }\end{array}$ & -0.131 \\
\hline $\begin{array}{l}>1.750-<=1.875 \\
\text { mile }\end{array}$ & -0.107 & $\begin{array}{l}>1.750-<=1.875 \\
\text { mile }\end{array}$ & -0.012 & $\begin{array}{l}>1.750-<=1.875 \\
\text { mile }\end{array}$ & -0.146 \\
\hline $\begin{array}{l}>1.875-<=2.000 \\
\text { mile }\end{array}$ & -0.105 & $\begin{array}{l}>1.875-<=2.000 \\
\text { mile }\end{array}$ & -0.030 & $\begin{array}{l}>1.875-<=2.000 \\
\text { mile }\end{array}$ & -0.026 \\
\hline $\begin{array}{l}\text { Model } \\
\text { Performance }\end{array}$ & & Model Performance & & San Jose & 0.245 \\
\hline Cases & 7,533 & Cases & 18,667 & $\begin{array}{l}\text { Model } \\
\text { Performance }\end{array}$ & \\
\hline R2, adjusted & 0.483 & R2, adjusted & 0.623 & Cases & 6,095 \\
\hline F-ratio & 181.068 & F-ratio & 771.499 & R2, adjusted & 0.264 \\
\hline $\begin{array}{l}\text { Descriptive } \\
\text { Statistics }\end{array}$ & & $\begin{array}{l}\text { Descriptive } \\
\text { Statistics }\end{array}$ & & F-ratio & 50.708 \\
\hline $\begin{array}{l}\text { Rent per Square } \\
\text { Foot }\end{array}$ & $\$ 21.86$ & $\begin{array}{l}\text { Rent per Square } \\
\text { Foot }\end{array}$ & $\$ 1.49$ & $\begin{array}{l}\text { Descriptive } \\
\text { Statistics }\end{array}$ & \\
\hline
\end{tabular}

Note: Bold means $\mathrm{p}<0.10$ as applied to experimental but not control variables. 


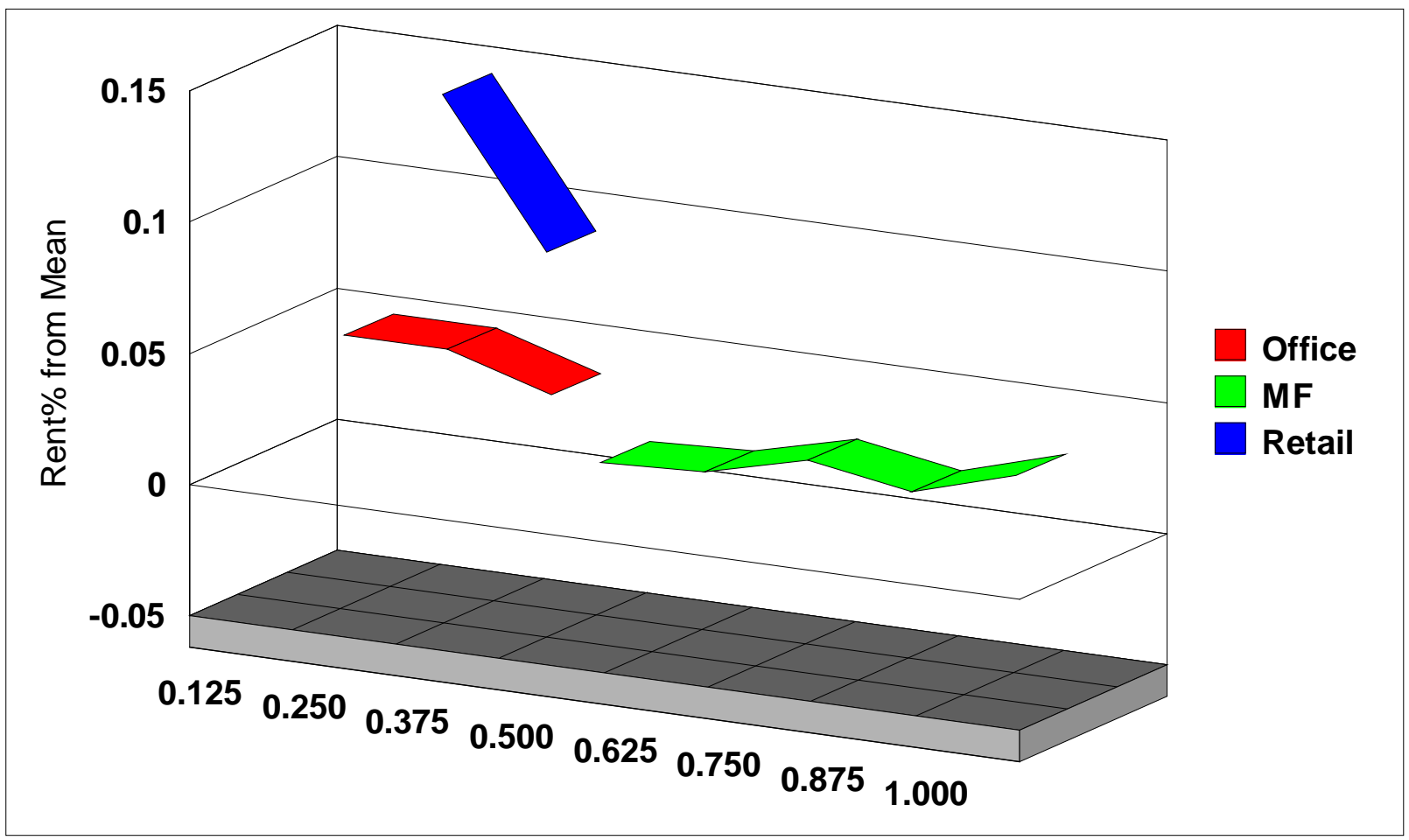

Figure 2.2: Illustration of Commercial Rents with Respect to Bus Rapid Transit Station Proximity to 1.00 Mile 
Table 2.5: Streetcar Commercial Rent Regression Equations with Respect to Streetcar Station Proximity by Distance Band

\begin{tabular}{|c|c|c|c|c|c|}
\hline \multicolumn{2}{|c|}{$\begin{array}{c}\text { Office Rents with Respect to } \\
\text { Streetcar Station Proximity }\end{array}$} & \multicolumn{2}{|c|}{$\begin{array}{c}\text { Apartment Rents with Respect to } \\
\text { Streetcar Station Proximity }\end{array}$} & \multicolumn{2}{|c|}{$\begin{array}{l}\text { Retail Rents with Respect to } \\
\text { Streetcar Station Proximity }\end{array}$} \\
\hline Variable & Office & Variable & Multifamily & Variable & Retail \\
\hline Constant & 0.001 & Constant & -3.208 & Constant & -5.877 \\
\hline Structural Controls & & Structural Controls & & Structural Controls & \\
\hline Gross Leasable Area & $-1.396 E-007$ & Gross Leasable Area & 1.755E-007 & Gross Leasable Area & $-1.613 E-006$ \\
\hline Class A Office & 0.367 & Average Unit Size & $-3.189 E-005$ & Stories & 0.021 \\
\hline Class B Office & 0.116 & Stories & $\mathbf{0 . 0 2 0}$ & Effective Year Built & 0.004 \\
\hline Stories & 0.003 & Effective Year Built & 0.002 & Vacancy Rate & -0.001 \\
\hline Effective Year Built & 0.001 & Vacancy Rate & 0.003 & Power Center & 0.231 \\
\hline Vacancy Rate & -0.001 & Occupancy Restrictions & & Neighborhood Center & -0.017 \\
\hline & & Senior Restriction & 0.076 & Community Center & 0.118 \\
\hline & $1.259 \mathrm{E}-006$ & Student Restriction & -0.174 & Regional Mall & 0.241 \\
\hline & & & & Lifestyle Center & 0.387 \\
\hline & & & & Outlet Center & 1.500 \\
\hline Socioeconomic Control & & Socioeconomic Control & & Socioeconomic Control & \\
\hline Median Household Income & 0.001 & Median Household Income & $1.965 \mathrm{E}-006$ & Median Household Income & $3.321 \mathrm{E}-006$ \\
\hline Land Use Controls & -0.014 & Land Use Controls & & Land Use Controls & \\
\hline Worker Labor Force Ratio & $-2.252 E-006$ & Workers per Labor Force & 0.003 & Workers per Labor Force & 0.004 \\
\hline Entropy & 8.185E-007 & Entropy & 0.135 & Entropy & 0.056 \\
\hline Location Controls & & Location Controls & & Location Controls & \\
\hline Distance Downtown Center & 0.087 & Distance Downtown Center & $-2.244 E-006$ & Distance Downtown Center & $-1.531 E-006$ \\
\hline Distance Freeway Ramp & 0.084 & Distance Freeway Ramp & $6.860 \mathrm{E}-007$ & Distance Freeway Ramp & 9.632E-007 \\
\hline Distance Bands & & Distance Bands & & Distance Bands & \\
\hline$<=0.125$ mile & 0.083 & $<=0.125$ mile & 0.208 & $<=0.125$ mile & 0.455 \\
\hline$>0.125-<=0.250$ mile & 0.143 & $>0.125-<=0.250$ mile & 0.215 & $>0.125-<=0.250$ mile & 0.215 \\
\hline$>0.250-<=0.375$ mile & 0.091 & $>0.250-<=0.375$ mile & 0.184 & $>0.250-<=0.375$ mile & 0.205 \\
\hline$>0.370-<=0.500$ mile & 0.018 & $>0.370-<=0.500$ mile & 0.171 & $>0.370-<=0.500$ mile & 0.307 \\
\hline$>0.500-<=0.625$ mile & 0.082 & $>0.500-<=0.625$ mile & 0.131 & $>0.500-<=0.625$ mile & 0.324 \\
\hline$>0.625-<=0.750$ mile & 0.006 & $>0.625-<=0.750$ mile & 0.116 & $>0.625-<=0.750$ mile & 0.178 \\
\hline$>0.750-<=0.875$ mile & 0.097 & $>0.750-<=0.875$ mile & 0.100 & $>0.750-<=0.875$ mile & 0.400 \\
\hline$>0.875-<=1.000$ mile & 0.042 & $>0.875-<=1.000$ mile & 0.099 & $>0.875-<=1.000$ mile & 0.108 \\
\hline$>1.000-<=1.125$ mile & -0.142 & $>1.000-<=1.125$ mile & 0.099 & $>1.000-<=1.125$ mile & 0.160 \\
\hline$>1.125-<=1.250$ mile & 0.018 & $>1.125-<=1.250$ mile & 0.103 & $>1.125-<=1.250$ mile & -0.084 \\
\hline$>1.250-<=1.375$ mile & 0.068 & $>1.250-<=1.375$ mile & 0.094 & $>1.250-<=1.375$ mile & -0.013 \\
\hline
\end{tabular}




\begin{tabular}{|c|c|c|c|c|c|}
\hline \multicolumn{2}{|c|}{$\begin{array}{l}\text { Office Rents with Respect to } \\
\text { Streetcar Station Proximity }\end{array}$} & \multicolumn{2}{|c|}{$\begin{array}{l}\text { Apartment Rents with Respect to } \\
\text { Streetcar Station Proximity }\end{array}$} & \multicolumn{2}{|c|}{$\begin{array}{l}\text { Retail Rents with Respect to } \\
\text { Streetcar Station Proximity }\end{array}$} \\
\hline$>1.370-<=1.500$ mile & 0.029 & $>1.370-<=1.500$ mile & 0.118 & $>1.370-<=1.500$ mile & 0.166 \\
\hline$>1.500-<=1.625$ mile & 0.064 & $>1.500-<=1.625$ mile & 0.112 & $>1.500-<=1.625$ mile & -0.063 \\
\hline$>1.625-<=1.750$ mile & 0.138 & $>1.625-<=1.750$ mile & 0.059 & $>1.625-<=1.750$ mile & -0.050 \\
\hline$>1.750-<=1.875$ mile & 0.172 & $>1.750-<=1.875$ mile & 0.097 & $>1.750-<=1.875$ mile & 0.119 \\
\hline$>1.875-<=2.000$ mile & 0.525 & $>1.875-<=2.000$ mile & 0.073 & $>1.875-<=2.000$ mile & 0.073 \\
\hline Model Performance & & Model Performance & & Model Performance & \\
\hline Cases & 133.402 & Cases & 11,236 & Cases & 2,220 \\
\hline R2, adjusted & 0.525 & R2, adjusted & 0.595 & R2, adjusted & 0.410 \\
\hline F-ratio & $\$ 23.73$ & F-ratio & 412.816 & F-ratio & 36.817 \\
\hline Descriptive Statistics & 3.0104 & Descriptive Statistics & & Descriptive Statistics & \\
\hline Rent per Square Foot & 90,264 & Rent per Square Foot & $\$ 17.87$ & Rent per Square Foot & $\$ 19.42$ \\
\hline
\end{tabular}

Note: Bold means $\mathrm{p}<0.10$ as applied to experimental but not control variables. 


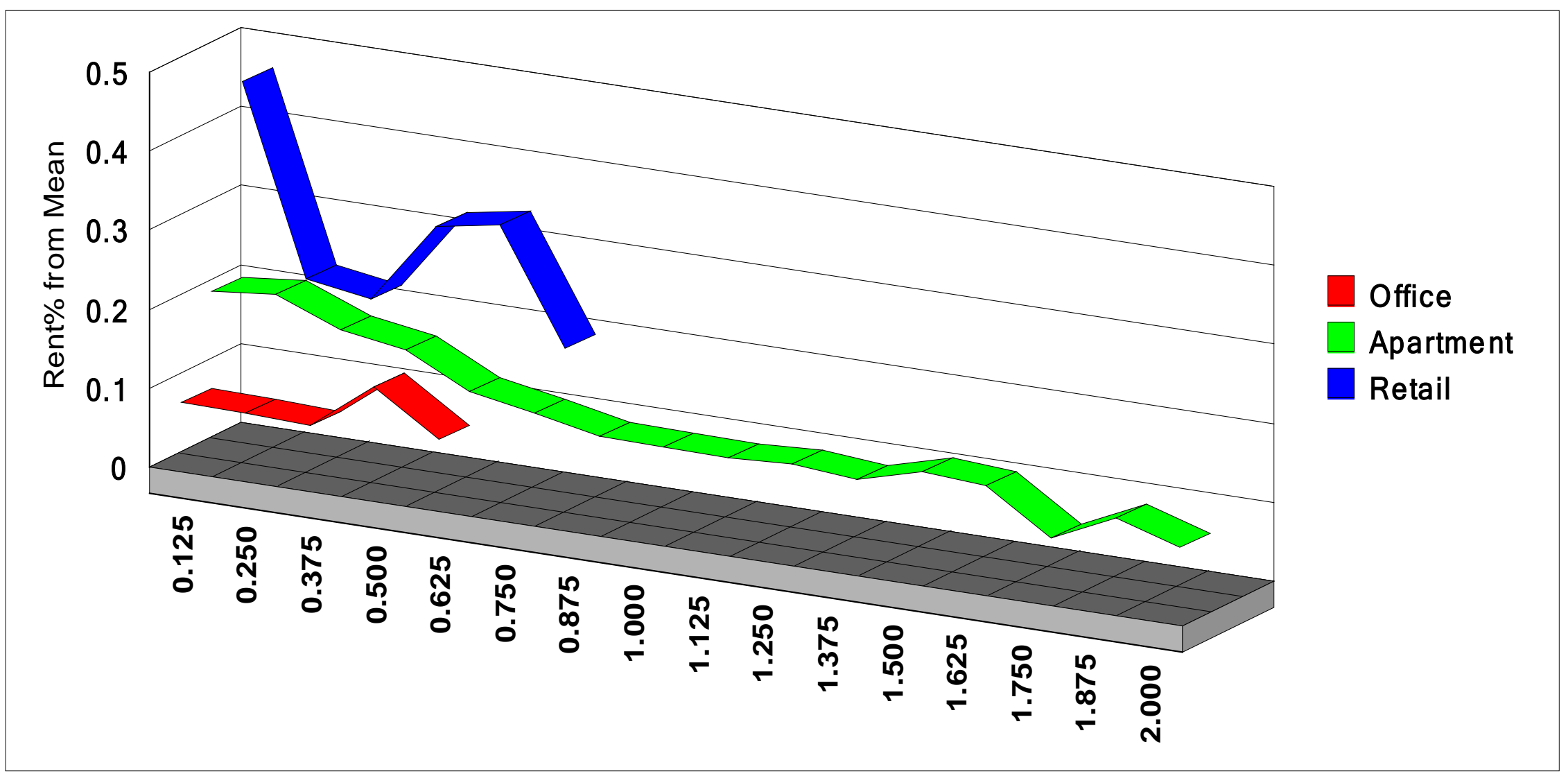

Figure 2.3: Illustration of Commercial Rents with Respect to Streetcar Station Proximity to 2.00 Miles 
Table 2.6: Streetcar Commercial Rent Regression Equations with Respect to CRT Station Proximity by Distance Band

\begin{tabular}{|c|c|c|c|c|c|}
\hline \multicolumn{2}{|c|}{$\begin{array}{l}\text { Office Rents with Respect to } \\
\text { CRT Station Proximity }\end{array}$} & \multicolumn{2}{|c|}{$\begin{array}{c}\text { Apartment Rents with Respect to } \\
\text { CRT Station Proximity }\end{array}$} & \multicolumn{2}{|c|}{$\begin{array}{c}\text { Retail Rents with Respect to } \\
\text { CRT Station Proximity }\end{array}$} \\
\hline Variables & Office Cases & Variables & MF Cases & Variables & Retail Cases \\
\hline Constant & 1.607 & Constant & -3.433 & Constant & 1.516 \\
\hline Structural Controls & & Structural Controls & & Structural Controls & \\
\hline Gross Leasable Area & $-3.709 E-007$ & Gross Leasable Area & 2.725E-007 & Gross Leasable Area & -9.403E-007 \\
\hline Class A Office & $\mathbf{0 . 2 8 9}$ & Average Unit Size & $-1.000 \mathrm{E}-003$ & Effective Year Built & 1.000E-003 \\
\hline Class B Office & 0.085 & Stories & 2.000E-002 & Vacancy Rate & $\mathbf{0 . 0 0 1}$ \\
\hline Stories & 0.011 & Effective Year Built & 0.002 & Power Center & 0.178 \\
\hline Effective Year Built & 0.001 & Vacancy Rate & 0.006 & Neighborhood Center & -0.031 \\
\hline \multirow[t]{4}{*}{ Vacancy Rate } & -0.001 & \multicolumn{2}{|c|}{ Occupancy Restriction Control } & Community Center & 0.053 \\
\hline & & Senior Restriction & -0.107 & Regional Mall & 0.479 \\
\hline & & Student Restriction & -0.056 & Lifestyle Center & 0.290 \\
\hline & & & & Outlet Center & 0.149 \\
\hline Socioeconomic Control & & Socioeconomic Control & & Socioeconomic Control & \\
\hline Median Household Income & $1.448 \mathrm{E}-006$ & Median Household Income & 2.922E-006 & Median Household Income & 2.777E-006 \\
\hline Land Use Controls & & Land Use Controls & & Land Use Mix Controls & \\
\hline Workers per Labor Force & 0.001 & Workers per Labor Force & 3.000E-003 & Workers per Labor Force & 0.002 \\
\hline Entropy & -0.061 & Entropy & 0.079 & Entropy & $1.000 \mathrm{E}-003$ \\
\hline Location Controls & & Location Controls & & Location Controls & \\
\hline Distance Downtown Center & $-1.605 E-006$ & Distance Downtown Center & $-1.046 E-006$ & Distance Downtown Center & $-1.244 \mathrm{E}-006$ \\
\hline Distance Freeway Ramp & 4.055E-006 & Distance Freeway Ramp & $-9.200 \mathrm{E}-007$ & Distance Freeway Ramp & -1.181E-006 \\
\hline Distance Bands & & Distance Bands & & Location Controls & \\
\hline$<=0.125$ mile & 0.136 & $<=0.125$ mile & 0.099 & $<=0.125$ mile & 0.016 \\
\hline$>0.125-<=0.250$ mile & 0.161 & $>0.125-<=0.250$ mile & 0.053 & $>0.125-<=0.250$ mile & 0.028 \\
\hline$>0.250-<=0.375$ mile & 0.169 & $>0.250-<=0.375$ mile & 0.046 & $>0.250-<=0.375$ mile & 0.009 \\
\hline$>0.370-<=0.500$ mile & 0.126 & $>0.370-<=0.500$ mile & 0.060 & $>0.370-<=0.500$ mile & 0.035 \\
\hline$>0.500-<=0.625$ mile & 0.056 & $>0.500-<=0.625$ mile & 0.054 & $>0.500-<=0.625$ mile & 0.009 \\
\hline$>0.625-<=0.750$ mile & 0.049 & $>0.625-<=0.750$ mile & 0.051 & $>0.625-<=0.750$ mile & -0.043 \\
\hline$>0.750-<=0.875$ mile & 0.036 & $>0.750-<=0.875$ mile & 0.020 & $>0.750-<=0.875$ mile & -0.013 \\
\hline$>0.875-<=1.000$ mile & 0.080 & $>0.875-<=1.000$ mile & 0.051 & $>0.875-<=1.000$ mile & -0.057 \\
\hline$>1.000-<=1.125$ mile & 0.015 & $>1.000-<=1.125$ mile & 0.026 & $>1.000-<=1.125$ mile & -0.021 \\
\hline$>1.125-<=1.250$ mile & 0.044 & $>1.125-<=1.250$ mile & 0.040 & $>1.125-<=1.250$ mile & -0.033 \\
\hline$>1.250-<=1.375$ mile & 0.019 & $>1.250-<=1.375$ mile & 0.051 & $>1.250-<=1.375$ mile & -0.036 \\
\hline
\end{tabular}




\begin{tabular}{|c|c|c|c|c|c|}
\hline \multicolumn{2}{|c|}{$\begin{array}{l}\text { Office Rents with Respect to } \\
\text { CRT Station Proximity }\end{array}$} & \multicolumn{2}{|c|}{$\begin{array}{l}\text { Apartment Rents with Respect to } \\
\text { CRT Station Proximity }\end{array}$} & \multicolumn{2}{|c|}{$\begin{array}{l}\text { Retail Rents with Respect to } \\
\text { CRT Station Proximity }\end{array}$} \\
\hline$>1.370-<=1.500$ mile & 0.037 & $>1.370-<=1.500$ mile & 0.054 & $>1.370-<=1.500$ mile & -0.021 \\
\hline$>1.500-<=1.625$ mile & 0.033 & $>1.500-<=1.625$ mile & 0.064 & $>1.500-<=1.625$ mile & 0.002 \\
\hline$>1.625-<=1.750$ mile & -0.018 & $>1.625-<=1.750$ mile & 0.049 & $>1.625-<=1.750$ mile & 0.011 \\
\hline$>1.750-<=1.875$ mile & 0.033 & $>1.750-<=1.875$ mile & 0.065 & $>1.750-<=1.875$ mile & -0.042 \\
\hline$>1.875-<=2.000$ mile & 0.030 & $>1.875-<=2.000$ mile & 0.040 & $>1.875-<=2.000$ mile & \\
\hline Model Performance & & Model Performance & & Model Performance & \\
\hline Cases & 13,257 & Cases & 22,578 & Cases & 12,613 \\
\hline R2, adjusted & 0.461 & R2, adjusted & 0.542 & R2, adjusted & 0.327 \\
\hline F-ratio & 284.862 & F-ratio & 653.760 & F-ratio & 140.413 \\
\hline Descriptive Statistics & & Descriptive Statistics & & Descriptive Statistics & \\
\hline Rent per Square Foot & $\$ 23.95$ & Rent per Square Foot & $\$ 1.61$ & Rent per Square Foot & $\$ 22.81$ \\
\hline
\end{tabular}

Note: Bold means $\mathrm{p}<0.10$ as applied to experimental but not control variables. 


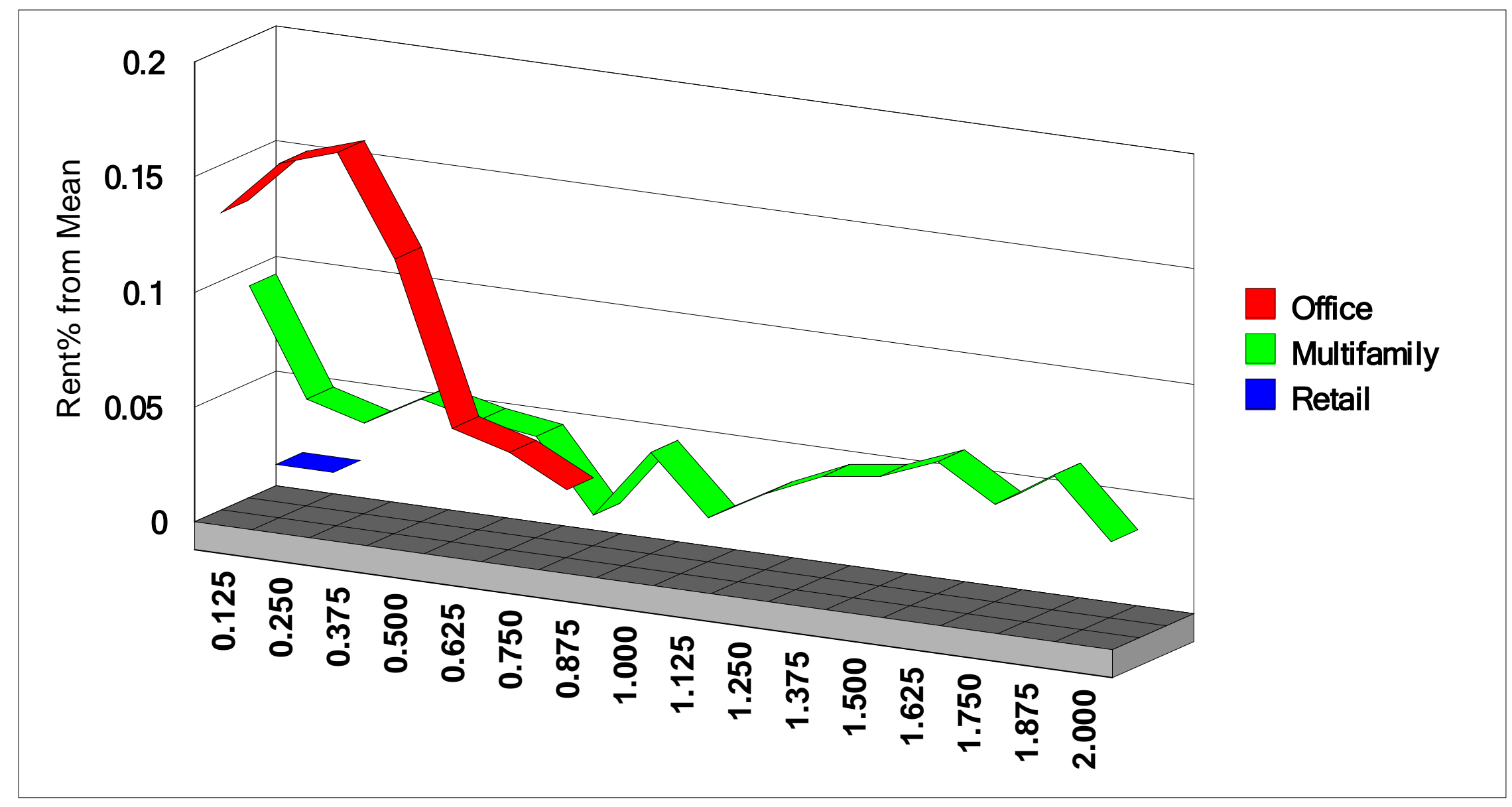

Figure 2.4: Illustration of Commercial Rents with Respect to Commuter Rail Transit Station Proximity to 2.00 Miles 
This page intentionally left blank. 


\section{REFERENCES}

Alonso W (1964). Location and Land Use: Toward a General Theory of Land Rent, Harvard University Press, Cambridge MA.

Ewing, Reid and Shima Hamidi (2018). The Costs of Sprawl. London: Routledge.

Hajrasouliha, Amir H. and Shima Hamidi (2017). The typology of the American metropolis: monocentricity, polycentricity, or generalized dispersion? Urban Geography 38:3, 420-444, DOI: 10.1080/02723638.2016.1165386.

Hibberd, Nelson, Currans. Functional Form in Hedonic Regression: Literature Review \& Test of Forms to Determine the End of Significance of Transit Proximity Effects on LVU. University of Arizona.

Higgins, Christopher D. Higgins \& Pavlos S. Kanaroglou (2016). Forty years of modelling rapid transit's land value uplift in North America: moving beyond the tip of the iceberg, Transport Reviews, 36:5, 610-634, DOI: 10.1080/01441647.2016.1174748

Ko, Kate \& Cao, Xinyu. 2013. The Impact of Hiawatha Light Rail on Commercial and Industrial Property Values in Minneapolis. Journal of Public Transportation, 16 (1): 47-66.

DOI: http://doi.org/10.5038/2375-0901.16.1.3

Mills ES (1967). An Aggregative Model of Resource Allocation in a Metropolitan Area, The American Economic Review, Papers and Proceedings, 57(2), pp 197-210. University of Chicago Press, Chicago.

Muth RF (1969). Cities and Housing: The Spatial Pattern of Urban Residential Land Use, Third Series: Studies in Business and Society.

Park, Robert Ezra, E. W. Burgess, Roderick Duncan McKenzie, and Louis Wirth. 1925. The city. Chicago, Ill: University of Chicago Press.

Nelson Arthur C. (2017). Transit and Real Estate Rents. Transportation Research Record: Journal of the Transportation Research Board. https://doi.org/10.3141/2651-03:

Nelson, Arthur C. (1992). Effects of Heavy-Rail Transit Stations on House Prices with Respect to Neighborhood Income, Transportation Research Record, 1359: 127-132.

Nelson, Arthur C. and Susan J. McClesky (1990). Elevated Rapid Rail Station Impacts on Single-Family House Values, Transportation Research Record, 1266: 173-180.

Nelson, Arthur C. Dejan Eskic, Shima Hamidi, Susan J. Petheram, Jenny H. Liu, Reid Ewing. 2015. Office Rent Premiums with Respect to Distance from Light Rail Transit Stations in Dallas. Transportation Research Record DOI 10.3141/2500-13.

Nelson, Arthur C. and Robert Hibberd (2019). Streetcars and Real Estate Rents. Transportation Research Record (forthcoming). 
Petheram, Susan J., Arthur C. Nelson, Matt Miller and Reid Ewing (2013). Using the Real Estate Market to Establish Light Rail Station Catchment Areas: Case Study of Attached Residential Property Values in Salt Lake County with respect to Light Rail Station Distance. Transportation Research Record. 2357: 95-99.

Stoker, Philip \& Reid Ewing (2014) Job-Worker Balance and Income Match in the United States, Housing Policy Debate, 24:2, 485-497, DOI: 10.1080/10511482.2013.852604

Streetcars, A History https://www.american-rails.com/streetcars.html accessed July 30, 2018. No author.

Xiao, Yang (2016). Hedonic Housing Price Theory Review in Urban Morphology and Housing Market, pp. 11-40. New York: Springer. 


\subsection{THE VARIATION OF ECONOMIC DEVELOPMENT WITH RESPECT TO FIXED ROUTE TRANSIT STATION PROXIMITY BEFORE, DURING AND AFTER THE GREAT RECESSION}

\subsection{OVERVIEW}

Among many promises of such fixed route transit (FRT) systems as light rail transit (LRT), bus rapid transit (BRT), streetcar transit (SCT), and commuter rail transit (CRT) is their contribution to regional economic development. There is scant evidence for this, however. A key reason is a dearth of studies testing the proposition. A second is that until recently, spatially related data at the national level were not available. A third is that the Great Recession (GR) may have had confounding effects on estimating economic development outcomes associated with FRT station proximity. This paper remedies these shortcomings.

This chapter descriptive analysis to investigate the influence of FRT station proximity on the change in the distribution of total workers before the Great Recession (2004 through 2007), the years during and immediately following the Great Recession (2008 through 2011), and after the Great Recession (2012-2015) —all equal periods of time. For the most part, total workers shifted away from FRT stations before the Great Recession, shifted toward them during the Great Recession, and continued to shift toward them since the Great Recession albeit at a slower pace. However, there is considerable variation based on the distance measures used, between systems and among economic sectors. These differences create a complex web of understanding how economic development-measured as workers - is affected by variations among transit systems, transit station proximity, and economic sectors.

In this chapter, we look simple at the change in total workers in "Transit Regions" with respect to FRT station proximity. These overall trends can tell transit and land use planners much about how firms and the people they hire may be influenced by transit station accessibility over time. Chapter 4 will explore emerging trends for both station proximity and worker by major economic groups as well as wages. Implications for fixed route transit system planning and economic development are offered at the end of the chapter.

\subsection{INTRODUCTION AND LITERATURE REVIEW}

Urban areas are formed and grow in large part by creating agglomeration economies (Glaeser, 2011). Annas, Arnott and Small define the term as "the decline in average cost as more production occurs within a specified geographical area” (1998, p. 1427). As more firms in related sectors cluster together, costs of production fall as productivity increases. These economies can spill over into complementary sectors (Holmes, 1999). Cities can become ever larger as economies of agglomeration are exploited (Ciccone and Hall, 1996). Transportation improvements make it possible to reduce transportation times, increasing the size of market areas and the effective size of industrial clusters. If cities get too large, however, transportation 
congestion may have a counter-productive force, encouraging the relocation of firms (Bogart, 1998). Highway projects have been shown to induce this change in metropolitan form, and at a net cost to society (Boarnet, 1997; Boarnet and Haughwout, 2000). More recent research shows that the degree of suburbanization significantly varies within metropolitan regions, in accordance to both variations in the levels of population de-concentration drivers and due to sub-regional fixed effects (Ganning and McCall, 2012). Thus, the preservation and creation of new agglomeration economies within metropolitan regions varies considerably and in ways that may be influenced by policy decisions.

A key role of fixed route transit (FRT) is to facilitate agglomeration economies by mitigating transportation congestion effects of automobile traffic induced by agglomeration. This is because, as Voith (1998) notes, public transit is essentially "noncongestible" and is best suited to sustaining agglomeration economies in high density nodes as well as along the corridors that connect them. Nonetheless, not all economic sectors benefit from agglomeration economies and/or density.

\subsubsection{Prior Research}

In part because of their role in facilitating agglomeration economies, there is a growing body of research showing that FRT systems enhance economic development (see Nelson et al., 2009). Transit improves accessibility between people and their destinations by reducing travel time relative to alternatives (Littman, 2009). At the metropolitan scale, adding FRT systems in builtup urban areas increases aggregate economic activity (Graham, 2007). There is another aspect of agglomeration economies identified by Chatman and Noland (2011). Although transit systems can lead to higher-density development by shifting new workers and population to station areas, it could lead instead to the redistribution of existing development even in the absence of growth, as in the case of Detroit (Galster, 2012).

Transit station-related agglomeration effects should be seen as a larger share of regional workers closer to transit stations than elsewhere in the region. At the time research began leading to this chapter, there were only four studies assessing worker change near transit stations. The first, Belzer et al. (2011), measured only the change in workers by economic sector from 2002 to 2008 within one-half mile of transition stations and not the change in share of regional workers. In the second, Nelson et al. (2011) evaluated the change in share of workers by sector within oneeighth mile and one-quarter mile of Eugene-Springfield BRT stations between 2004 and 2010. The third and fourth studies (Nelson et al. 2015, Nelson 2016) evaluated several LRT, BRT, SCT and CRT systems in one-quarter mile distance band increments from transit stations to track shifts in the share of workers by economic group (see Table 1) before and during the recession. A key finding for LRT systems is that while station areas lost regional share of workers before the Great Recession (2004 through 2007), they gained share during it (Nelson, Stoker and Hibberd 2018), though results for other modes were mixed (see Nelson et al. 2015, Nelson 2016).

\subsubsection{The Nelson-Stoker-Hibberd Resilience Hypothesis}

In 2018, Nelson, Stoker and Hibberd (2018) advanced their Resilience Hypothesis. They note that the ecological concept of "resilience” has been applied to social and economic systems in 
researchers' attempts to understand the extent to which those systems recover after calamity. They apply the concept of resilience to the seven LRT systems operating in the U.S. before, during and after the Great Recession. Using economic base analysis across groups of economic sectors, they trace change in the share of workers before, during and immediately after the Great Recession. They find that economic activity within 0.50-mile of LRT stations was more resilient during the Great Recession than their metropolitan areas as a whole, and those economies appear to have been transformed such that workers were shifting substantially more to LRT corridors in the post-recession period than before. The present study applied their Resilience Hypothesis to more systems, more types of systems, and longer time periods than their earlier work.

Finally, it is import to note that to this point, there are no national studies evaluating the variation in regional share of workers with respect to transit station distance before, during and after the Great Recession for multiple FRT systems. This chapter helps close this gap in the literature. In particular, the focus of the research reported here is to determine:

- Whether and the extent to which transit systems are associated with higher shares of regional workers in distance bands closer to transit stations and

- The extent to which worker shares with respect to distance bands changes over time before (2004-2007), during (2008-2011) and after (2012-2015) the Great Recession.

\subsection{RESEARCH QUESTION AND DESIGN}

Theoretically, areas near transit stations should have much better accessibility. By reducing the effects of congestion, transit stations should abet both the preservation of existing agglomeration economies and the creation of new ones. Without the diseconomies of congestion, existing employment clusters should continue to grow, and the relative concentration of employment within clusters served by transit systems should grow and continue to increase.

Based on our theory, transit oriented development (TOD) areas serving such fixed route transit systems as LRT should retain if not capture a higher share of workers than their regions during an economic downturn and afterward. Our first research question is simple:

\section{Do FRT station areas capture proportionately more workers than their regions over time and are there variations by transit type and age of systems?}

We mean the term "capture" as the share of total workers and workers within two-digit NAICS sectors that are within census blocks whose edges are with 0.125 (one-eighth) mile distance bands of FRT stations as described in our data below.

We use a pre-post design with an interrupted time period to address the research question. Next, we review our data, study period, the FRT systems selected for analysis, and analytic approach. This is followed by results and implications.

\subsubsection{Data}

Because we evaluate the change in the distribution of total workers over time, we use employment data. The source of data is the Longitudinal Employer-Household Dynamics 
(LEHD) program which is part of the Center for Economic Studies at the U.S. Census Bureau.6 For all FRT systems studied, two-digit NAICS data are available annually from 2004 through 2015 at the census block level. We include every block whose closest point is within 0.125 mile of the nearest LRT station point.

\subsubsection{Study Periods}

We evaluate shift in shares of workers over three discrete time periods extending from before the Great Recession of the late 2000s, through the Great Recession itself, and afterward:

- 2004-2007 covers the period of relatively constant growth from the early 2000s to the end of 2007. This is the pre-shock period that we call "pre-recession".

- 2008-2011 covers the period of the Great Recession. According to Nelson, Stoker and Hibberd (2018), FRT station areas should retain if not capture a higher share of the shift of regional workers than their regions as a whole. This is the "interrupted period".

- 2012-2015 covers the period after the Great Recession which we call "post-recession". This is the post-test period. Based on our theory, FRT station areas should capture a higher share of the shift of regional workers than their metropolitan areas as a whole. Whether this share in the shift would be higher than predicted during the Great Recession we cannot say, but we can predict it should be higher than the pre-recession period.

\subsubsection{Fixed Route Transit Systems Studied}

Table 3.1 shows the FRT systems we include in our analysis. We excluded systems in the largest metropolitan areas (such as New York City, Chicago, Los Angeles) or metropolitan areas with a complex web of public transit (such as Boston, Philadelphia, San Francisco-Oakland) because we wanted to estimate outcomes associated with individual systems independent of the influences of multiple systems.

\subsubsection{Analytic Approach}

Given that change in employment share over time is our principal interest, we choose descriptive analysis as our analytic approach to assess change in the distribution of workers within and between time periods before, during and after the Great Recession with respect to transit station proximity.

We analyze those workers that normally occupy space in urban settings. This excludes the North American Industrial Classification System (NAICS) sectors of agriculture, forestry, mining, and construction. We also exclude the industrial sectors (utilities, manufacturing, transportation and warehousing, and wholesale trade) because of their land-extensive nature, making them usually

\footnotetext{
${ }^{1}$ For details, see http://lehd.ces.census.gov/.
} 
unsuitable per se for locating near transit stations.7 We further assemble other sectors into roughly comparable space-consuming land uses based on Nelson et al. (2015) that are reported in Table 3.2. This allows us to detect differences in the nature of changes in the distribution of workers over time by comparable land use categories. As noted earlier, we evaluate employment performance within 0.125 (one-eighth) mile of FRT stations.

Our analysis considered only those systems operating during any part of each study period. For instance, as there were only three BRT systems in the US operating before the GR, our analysis considered only those systems (see Table 3.1). This increased to 11 systems during the GR and 17 after. This achieves internal analytic consistency within time periods. Generally, we assigned FRT systems to periods as follows. Systems were organized by decade of initial operations including:

- 1980 s (including the 1970s for the first Pittsburgh BRT lines) which covers the period both before the Great Recession and the decade before LEHD data were available;

- 1990s which covers the period both before the Great Recession and also the decade before LEHD data were available;

- 2000s which covers the period when systems were substantially being planned, constructed and operation mostly before the Great Recession and for which LEHD data became available (being 2002 for most systems outside Arizona for which data are available since 2004); and

- 2010s which covers those systems launched either during or after the Great Recession.

In some cases, such as LRT systems for which only one was launched in the 2010s, we assigned it to the decade of the 2000s. We note FRT system assignments below.

Assigning systems to decades helps accomplish two things. First, for the older and more mature systems, analysts should know that those systems were already operating a decade or more before LEHD data became available. In effect, for those systems, LEHD data can be interpreted as outcomes associated with mature systems, unlike for instance systems launched in the 2000s when LEHD data became available.

Second, age of operations also reflect transit and land use planning approaches at the time. For instance, in the 1980s, LRT systems were often designed to connect nodes, such as suburban centers to downtowns, without much thought that station areas could themselves evolve into discrete sub centers. LRT systems in Portland, Sacramento, San Diego and San Jose, for instance, followed freeway corridors, sometimes being placed in freeway medians, and often elevated so that passengers needed to elevate, escalate, or amble up to platforms and then back down (Cervero et al. 2004). As Chapter 2 shows, these station locations add little to real estate value and can actually be viewed as a negative externality in the market, thereby dampening

${ }^{3}$ Urban microbreweries and small-scale crafts shops are the kinds of exceptions that support our general rule. 
value. Chapter 8 explores these concerns through visual examples and correlations between real estate rents, accessibility, and station location and design. As experience grows, modern LRT (and others) are located and designed to create positive user and real estate benefits.

Our method includes calculation of z-scores $(p<0.05)$ to assess whether differences between periods of time are statistically significant. They were, in all cases. Although this step may not be necessary because the analysis is of the total universe of workers and locations, we do so nonetheless.

We note that our methods only creates an association between FRT station proximity and change in the distribution of workers over time. We do not derive causal relationships.

Table 3.1: Fixed Route Transit (FRT) Systems Studies Using Economic Base-Shift-Share Analysis

\begin{tabular}{l|l|l|l|l|l|l|c}
\hline $\begin{array}{l}\text { Light Rail } \\
\text { Transit }\end{array}$ & Year & $\begin{array}{l}\text { Bus Rapid } \\
\text { Transit }\end{array}$ & Year & $\begin{array}{l}\text { Streetcar } \\
\text { Transit }\end{array}$ & Year & $\begin{array}{l}\text { Commuter Rail } \\
\text { Transit }\end{array}$ & Year \\
\hline Buffalo & 1984 & Cleveland & 2008 & Atlanta & 2014 & $\begin{array}{l}\text { Albuquerque-Santa } \\
\text { Fe }\end{array}$ & 2006 \\
\hline Charlotte & 2007 & $\begin{array}{l}\text { Eugene- } \\
\text { Springfield }\end{array}$ & 2007 & Cincinnati & 2016 & Austin & 2010 \\
\hline Cleveland & 1980 & Kansas City & 2005 & Dallas & 2015 & Dallas-Fort Worth & 1996 \\
\hline Dallas & 1996 & Las Vegas & 2004 & Kansas City & 2016 & Miami Tri-Rail & 1989 \\
\hline Denver & 1994 & Nashville & 2009 & Little Rock & 2004 & Minneapolis & 1997 \\
\hline Houston & 2004 & Phoenix & 2009 & New Orleans & 2016 & Nashville & 2006 \\
\hline $\begin{array}{l}\text { Minneapolis-St. } \\
\text { Paul }\end{array}$ & 2004 & Pittsburgh & 1977 & Portland & 2001 & Orlando & 2014 \\
\hline Norfolk & 2011 & Reno & 2010 & Salt Lake City & 2013 & Portland & 2009 \\
\hline Phoenix & 2008 & Salt Lake City & 2008 & Seattle & 2007 & Salt Lake City & 2008 \\
\hline Pittsburgh & 1984 & San Antonio & 2012 & Tacoma & 2003 & San Diego & 1995 \\
\hline Portland & 1986 & San Diego & 2014 & Tampa & 2002 & San Jose-Stockton & 1998 \\
\hline Sacramento & 1987 & Seattle & 2010 & Tucson & 2014 & Seattle-Tacoma & 2000 \\
\hline Salt Lake City & 1999 & Stockton & 2007 & Washington, DC & 2016 & & \\
\hline San Diego & 1981 & & & & & & \\
\hline San Jose & 1987 & & & & & & \\
\hline Seattle & 2003 & & & & & \\
\hline St. Louis & 1993 & & & & & \\
\hline
\end{tabular}




\subsection{FINDINGS}

In review, we calculate the change in total workers by 0.125 -mile distance band to 0.50 mile within each of the study periods, and between them. For each study period, we calculate the change in total workers from the:

- Transit station to 0.125-mile away;

- More than 0.125 from transit station to 0.25-mile away;

- Transit station to 0.25-mile away;

- More than 0.25 mile away from transit station to 0.50-mile away; and

- Transit station to 0.50-mile away.

We use LEHD workers for economic groups noted in Table 3.2 at the census block level for each time period. The following subsections report results for LRT, BRT, SCT and CRT systems, respectively.

\subsubsection{Light Rail Transit Station Proximity and Worker Change}

LRT systems in our analysis were built between 1980 (Cleveland) and 2011 (Norfolk) with most systems being expanded from an initial line to several and/or adding stations. Though the appendix reports results for each system, we combine systems for analysis as described below.

\subsubsection{1 $\quad 1^{\text {st }}$ Generation LRT Systems-East}

Three of the four oldest LRT systems in our analysis were constructed in the East during the 1980s and they comprise this group of systems:

- Buffalo 1984

- Cleveland 1980

- Pittsburgh 1984

Table 3.3 shows the change in workers with each time period. This table and all subsequent ones are designed as follows:

- Distance Band means the distance of a census block's nearest point to the nearest transit station;

- Transit Region UA (sq.mi.) means the urbanized land area of the counties within which the transit system operates using the Census definition of what comprises urbanized land as of 2016; 
- Distance Band Share of Transit Region UA means the share of the Distance Band UA as a percent of the Transit Region US;

- Station Area Worker Change 2004-2007, 2008-2011, 2012-2015 means the change in workers within the respective distance bands between the years noted;

- Share of Regional Worker Change 2004-2007, 2008-2011, 2012-2015 means the change in distance band workers as a percent of Transit Region worker change within each period; and

- Transit region worker change with period.

Table 3.3 confirms the Nelson-Stoker-Hibberd Resilience Hypothesis. Notably:

- Before the recession, station areas aggregated to the 0.50-mile distance band lost workers numerically and overall share of workers compared to the Transit Region;

- During the Great Recession, station areas within the 0.25-mile distance band gained workers, accounting for nearly a third (31\%) of new Transit Region workers; and

- After the recession the nearest distance band, 0.125-mile, added more than 14,000 new workers while the rest of the Transit Region added fewer than 8,000 workers.

- We observe that station areas with the 0.50-mile distance band added nearly 19,000 workers or 2.3 times more workers than the Transit Region, meaning that this distance band may be attracting new workers while the rest of the Transit Region is losing workers.

Table 3.3: Change in Total Workers by Time Period, $1^{\text {st }}$ Generation East LRT Systems

\begin{tabular}{|c|c|c|c|c|c|c|c|c|c|}
\hline $\begin{array}{l}\text { Distance } \\
\text { Band }\end{array}$ & $\begin{array}{r}\text { Transit } \\
\text { Region } \\
\text { UA } \\
\text { (sq.mi.) }\end{array}$ & $\begin{array}{r}\text { Distance } \\
\text { Band } \\
\text { UA } \\
\text { (sq.mi.) }\end{array}$ & $\begin{array}{r}\text { Distance } \\
\text { Band } \\
\text { Share of } \\
\text { Transit } \\
\text { Region } \\
\text { UA }\end{array}$ & $\begin{array}{r}\text { Station } \\
\text { Area } \\
\text { Worker } \\
\text { Change } \\
2004- \\
2007\end{array}$ & $\begin{array}{r}\text { Share of } \\
\text { Regional } \\
\text { Worker } \\
\text { Change } \\
2004- \\
2007 \\
\end{array}$ & $\begin{array}{r}\text { Station } \\
\text { Area } \\
\text { Worker } \\
\text { Change } \\
2008- \\
2011\end{array}$ & $\begin{array}{r}\text { Share of } \\
\text { Regional } \\
\text { Worker } \\
\text { Change } \\
2008- \\
2011 \\
\end{array}$ & $\begin{array}{r}\text { Station } \\
\text { Area } \\
\text { Worker } \\
\text { Change } \\
2012- \\
2015\end{array}$ & $\begin{array}{r}\text { Share of } \\
\text { Regional } \\
\text { Worker } \\
\text { Change } \\
2012- \\
2015 \\
\end{array}$ \\
\hline $\begin{array}{l}0.00- \\
0.125 \\
\end{array}$ & $1,949.6$ & 4.9 & $0.82 \%$ & 1,952 & $9.0 \%$ & 6,632 & $22.9 \%$ & 14,051 & $177.9 \%$ \\
\hline $\begin{array}{l}0.125- \\
0.25\end{array}$ & $1,949.6$ & 10.5 & $1.78 \%$ & $(6,463)$ & $-29.6 \%$ & 2,335 & $8.1 \%$ & $(3,116)$ & $-39.5 \%$ \\
\hline $\begin{array}{l}0.00- \\
0.25\end{array}$ & $1,949.6$ & 15.5 & $2.60 \%$ & $(4,511)$ & $-20.7 \%$ & 8,967 & $31.0 \%$ & 10,935 & $138.5 \%$ \\
\hline $\begin{array}{l}0.25- \\
0.50\end{array}$ & $1,949.6$ & 22.3 & $3.93 \%$ & 3,189 & $14.6 \%$ & $(4,937)$ & $-17.1 \%$ & 7,604 & $96.3 \%$ \\
\hline $\begin{array}{l}0.00- \\
0.50\end{array}$ & $1,949.6$ & 37.7 & $6.53 \%$ & $(1,322)$ & $-6.1 \%$ & 4,030 & $13.9 \%$ & 18,539 & $234.8 \%$ \\
\hline \multicolumn{4}{|c|}{$\begin{array}{l}\text { Transit Region worker change within } \\
\text { period }\end{array}$} & 21,805 & & 28,932 & & 7,897 & \\
\hline
\end{tabular}

Z-scores show that all differences are statistically significant at $\mathrm{p}<0.05$. 


\subsubsection{2 $\quad 1^{\text {st }}$ Generation LRT Systems-West}

Another four LRT systems were built in West Coast states also in the 1980s:

$\begin{array}{ll}\text { Portland } & 1986 \\ \text { Sacramento } & 1987 \\ \text { San Diego } & 1981 \\ \text { San Jose } & 1987\end{array}$

Table 3.4 reports overall results. Despite adding many times more workers than seen in $1^{\text {st }}$ Generation LRT Transit Regions, patterns were the same, namely:

- Before the recession, station areas aggregated to the 0.50 -mile distance band lost workers numerically and overall share of workers compared to the Transit Region;

- During the Great Recession, station areas within the 0.25-mile distance band accounted for all (92\%) of new Transit Region workers; and

- After the recession the 0.25-mile distance band accounted for more than a fifth (21\%) of all new Transit Region workers.

We note that station areas with the 0.50 -mile distance band added nearly 80,000 workers or about $30 \%$ of all new workers in the Transit Region.

Table 3.4: Change in Total Workers by Time Period, $1^{\text {st }}$ Generation West LRT Systems

\begin{tabular}{|c|c|c|c|c|c|c|c|c|c|}
\hline $\begin{array}{l}\text { Distance } \\
\text { Band }\end{array}$ & $\begin{array}{r}\text { Transit } \\
\text { Region } \\
\text { UA } \\
\text { (sq.mi.) }\end{array}$ & $\begin{array}{r}\text { Distance } \\
\text { Band } \\
\text { UA } \\
\text { (sq.mi.) } \\
\end{array}$ & $\begin{array}{r}\text { Distance } \\
\text { Band } \\
\text { Share of } \\
\text { Transit } \\
\text { Region } \\
\text { UA } \\
\end{array}$ & $\begin{array}{r}\text { Station } \\
\text { Area } \\
\text { Worker } \\
\text { Change } \\
2004- \\
2007 \\
\end{array}$ & $\begin{array}{r}\text { Share of } \\
\text { Regional } \\
\text { Worker } \\
\text { Change } \\
2004- \\
2007 \\
\end{array}$ & $\begin{array}{r}\text { Station } \\
\text { Area } \\
\text { Worker } \\
\text { Change } \\
2008- \\
2011 \\
\end{array}$ & $\begin{array}{r}\text { Share of } \\
\text { Regional } \\
\text { Worker } \\
\text { Change } \\
2008- \\
2011 \\
\end{array}$ & $\begin{array}{r}\text { Station } \\
\text { Area } \\
\text { Worker } \\
\text { Change } \\
2012- \\
2015 \\
\end{array}$ & $\begin{array}{r}\text { Share of } \\
\text { Regional } \\
\text { Worker } \\
\text { Change } \\
2012- \\
2015 \\
\end{array}$ \\
\hline $\begin{array}{l}0.00- \\
0.125\end{array}$ & $1,883.21$ & 15.30 & $0.8 \%$ & $(59,790)$ & $-38.5 \%$ & 65,587 & $53.5 \%$ & 36,601 & $13.9 \%$ \\
\hline $\begin{array}{l}0.125- \\
0.25 \\
\end{array}$ & $1,883.21$ & 35.85 & $1.9 \%$ & 6,773 & $4.4 \%$ & 46,974 & $38.3 \%$ & 17,706 & $6.7 \%$ \\
\hline $\begin{array}{l}0.00- \\
0.25 \\
\end{array}$ & $1,883.21$ & 51.15 & $2.7 \%$ & $(53,017)$ & $-34.2 \%$ & 112,561 & $91.8 \%$ & 54,307 & $20.6 \%$ \\
\hline $\begin{array}{l}0.25- \\
0.50\end{array}$ & $1,883.21$ & 100.28 & $5.3 \%$ & 13,771 & $8.9 \%$ & 7,048 & $5.7 \%$ & 25,467 & $9.7 \%$ \\
\hline $\begin{array}{l}0.00- \\
0.50\end{array}$ & 1,883.21 & 151.43 & $8.0 \%$ & $(39,246)$ & $-25.3 \%$ & 119,609 & $97.5 \%$ & 79,774 & $30.2 \%$ \\
\hline $\begin{array}{l}\text { Transit K } \\
\text { within pe }\end{array}$ & ion worke & hange & 155,119 & & & 122,659 & & 263,810 & \\
\hline
\end{tabular}

Z-scores show that all differences are statistically significant at $\mathrm{p}<0.05$. 
These are the oldest and most mature LRT systems included in our study. We surmise that in their fourth decade markets may be responding to the resilience advantages transit station proximity allows. And though land use planning may also be encouraging development near transit station our sense of the literature and professional experience is that there is more flexible land use controls and more subsidies to lure economic development to locations away from transit stations than to nearby ones.

\subsubsection{3 $\quad 2^{\text {nd }}$ Generation LRT Systems-West}

Four LRT systems were constructed in the 1990s with three in western states and one (St. Louis-1993) in the East. Results for St. Louis are mixed (see Chapter 3 Appendix) perhaps because of problematic station location and/or design (see Chapter 8). We focus on the three $2^{\text {nd }}$ Generation LRT Systems constructed in the West, being:

- Dallas

- Denver

- Salt Lake City
1996

1994

1999

Results, shown in Table 3.5, are different from those seen for the $1^{\text {st }}$ generation LRT systems. Notably, while close-in distance bands saw increases in workers that accounted for modest shares of Transit Region worker gains, they lost workers during the Great Recession while the Transit Region added workers. While those systems gained workers during the post-recession period, they were modest. As well will show in Chapter 5, one reason may be that workers near these transit stations are being displaced by people and households moving into them. 
Table 3.5: Change in Total Workers by Time Period, $2^{\text {nd }}$ Generation West LRT Systems

\begin{tabular}{|c|c|c|c|c|c|c|c|c|c|}
\hline $\begin{array}{c}\text { Distance } \\
\text { Band } \\
\end{array}$ & $\begin{array}{c}\text { Transit } \\
\text { Region } \\
\text { UA } \\
\text { (sq.mi.) } \\
\end{array}$ & $\begin{array}{c}\text { Distance } \\
\text { Band } \\
\text { UA } \\
\text { (sq.mi.) } \\
\end{array}$ & $\begin{array}{c}\text { Distance } \\
\text { Band } \\
\text { Share of } \\
\text { Transit } \\
\text { Region } \\
\text { UA } \\
\end{array}$ & $\begin{array}{c}\text { Station } \\
\text { Area } \\
\text { Worker } \\
\text { Change } \\
\text { 2004- } \\
2007 \\
\end{array}$ & $\begin{array}{c}\text { Share of } \\
\text { Regional } \\
\text { Worker } \\
\text { Change } \\
2004- \\
2007 \\
\end{array}$ & $\begin{array}{c}\text { Station } \\
\text { Area } \\
\text { Worker } \\
\text { Change } \\
2008- \\
2011 \\
\end{array}$ & $\begin{array}{c}\text { Share of } \\
\text { Regional } \\
\text { Worker } \\
\text { Change } \\
2008- \\
2011 \\
\end{array}$ & $\begin{array}{c}\text { Station } \\
\text { Area } \\
\text { Worker } \\
\text { Change } \\
2012- \\
2015 \\
\end{array}$ & $\begin{array}{c}\text { Share of } \\
\text { Regional } \\
\text { Worker } \\
\text { Change } \\
2012- \\
2015 \\
\end{array}$ \\
\hline $\begin{array}{l}0.00- \\
0.125 \\
\end{array}$ & $2,850.4$ & 9.1 & $1.7 \%$ & 27,260 & $8.7 \%$ & $(15,199)$ & $-14.7 \%$ & 5,463 & $1.3 \%$ \\
\hline $\begin{array}{c}0.125- \\
0.25\end{array}$ & $2,850.4$ & 23.2 & $4.0 \%$ & 10,283 & $3.3 \%$ & $(2,953)$ & $-2.8 \%$ & 1,891 & $0.4 \%$ \\
\hline $\begin{array}{l}0.00- \\
0.25\end{array}$ & $2,850.4$ & 32.3 & $5.6 \%$ & 37,543 & $11.9 \%$ & $(18,152)$ & $-17.5 \%$ & 7,354 & $1.7 \%$ \\
\hline $\begin{array}{l}0.25- \\
0.50 \\
\end{array}$ & $2,850.4$ & 76.2 & $12.2 \%$ & 8,306 & $2.6 \%$ & $(6,427)$ & $-6.2 \%$ & 37,465 & $8.8 \%$ \\
\hline $\begin{array}{l}0.00- \\
0.50\end{array}$ & $2,850.4$ & 108.4 & $17.9 \%$ & 45,849 & $14.6 \%$ & $(24,579)$ & $-23.7 \%$ & 44,819 & $10.5 \%$ \\
\hline $\begin{array}{l}\text { Transit I } \\
\text { period } \\
\end{array}$ & ion worke & lange $w$ & & 314,768 & & 103,693 & & 425,997 & \\
\hline
\end{tabular}

Z-scores show that all differences are statistically significant at $\mathrm{p}<0.05$.

\subsubsection{4 $\quad 3^{\text {rd }}$ Generation LRT Systems}

Six of the LRT systems we studied were built after 2000:

- Charlotte 2007

- Houston 2004

- Minneapolis-St. Paul 2004

- Norfolk 2011

- Phoenix 2008

- Seattle 2003

With respect to workers, they all had the same pattern in that they gained workers within the 0.50-mile distance band over all three periods in roughly equivalent shares, accounting for about $15 \%$ of Transit Region worker growth. But we note an important trend which is seen in Table 3.6. During the Great Recession, more than a quarter (28\%) of the Transit Region worker growth located within the first (0.125-mile) distance band and more than $40 \%$ of the Transit Region worker growth occurred in the 0.25 -mile distance band. We further note important trends:

Whereas before the Great Recession, the innermost (0.125-mile) distance band accounted for about 2,000 workers and less than 1\% of the share of new Transit Region workers, it absorbed more than 20,000 workers and accounted for $28 \%$ of all new Transit Region workers; 
While the 0.25 -mile distance band accounted for about $12 \%$ of new post-recession workers the number of new workers in this distance band is nearly twice that seen in the previous two periods; and

With just $1.8 \%$ of the total Transit Region urban area (UA), the innermost (0.125-mile) distance band accounted for four times more workers (7.7\% of new workers locating on $1.8 \%$ of the Transit Region UA).

With the exception of $2^{\text {nd }}$ Generation LRT systems - which warrant future detailed study into reasons - we conclude that LRT systems contribute to regional economic resilience substantially in ways advanced by Nelson-Stoker-Hibberd.

Table 3.6: Change in Total Workers by Time Period, $3^{\text {rd }}$ Generation LRT Systems

\begin{tabular}{|c|c|c|c|c|c|c|c|c|c|}
\hline $\begin{array}{c}\text { Distance } \\
\text { Band }\end{array}$ & $\begin{array}{c}\text { Transit } \\
\text { Region } \\
\text { UA } \\
\text { (sq.mi.) }\end{array}$ & $\begin{array}{c}\text { Distance } \\
\text { Band } \\
\text { UA } \\
\text { (sq.mi.) }\end{array}$ & $\begin{array}{c}\text { Distance } \\
\text { Band } \\
\text { Share of } \\
\text { Transit } \\
\text { Region } \\
\text { UA }\end{array}$ & $\begin{array}{c}\text { Station } \\
\text { Area } \\
\text { Worker } \\
\text { Change } \\
2004- \\
2007\end{array}$ & $\begin{array}{c}\text { Share of } \\
\text { Regional } \\
\text { Worker } \\
\text { Change } \\
2004- \\
2007\end{array}$ & $\begin{array}{c}\text { Station } \\
\text { Area } \\
\text { Worker } \\
\text { Change } \\
2008- \\
2011\end{array}$ & $\begin{array}{c}\text { Share of } \\
\text { Regional } \\
\text { Worker } \\
\text { Change } \\
2008- \\
2011\end{array}$ & $\begin{array}{c}\text { Station } \\
\text { Area } \\
\text { Worker } \\
\text { Change } \\
2012- \\
2015\end{array}$ & $\begin{array}{c}\text { Share of } \\
\text { Regional } \\
\text { Worker } \\
\text { Change } \\
2012- \\
2015\end{array}$ \\
\hline $\begin{array}{l}0.00- \\
0.125\end{array}$ & $4,120.4$ & 8.6 & $1.8 \%$ & 2,249 & $0.5 \%$ & 20,048 & $27.7 \%$ & 37,409 & $7.7 \%$ \\
\hline $\begin{array}{c}0.125- \\
0.25\end{array}$ & $4,120.4$ & 23.0 & $8.1 \%$ & 30,144 & $7.2 \%$ & 9,279 & $12.8 \%$ & 20,101 & $4.1 \%$ \\
\hline $\begin{array}{c}0.00- \\
0.25 \\
\end{array}$ & $4,120.4$ & 31.6 & $9.9 \%$ & 32,393 & $7.7 \%$ & 29,327 & $40.5 \%$ & 57,510 & $11.8 \%$ \\
\hline $\begin{array}{l}0.25- \\
0.50 \\
\end{array}$ & $4,120.4$ & 55.2 & $12.4 \%$ & 45,339 & $10.8 \%$ & $(20,156)$ & $-27.8 \%$ & 24,565 & $5.1 \%$ \\
\hline $\begin{array}{c}0.00- \\
0.50\end{array}$ & $4,120.4$ & 84.5 & $18.8 \%$ & 77,732 & $18.5 \%$ & 9,171 & $12.7 \%$ & 82,075 & $16.9 \%$ \\
\hline $\begin{array}{l}\text { Transit } \\
\text { period }\end{array}$ & ion work & rge & & 421,165 & & 72,432 & & 485,712 & \\
\hline
\end{tabular}

Z-scores show that all differences are statistically significant at $\mathrm{p}<0.05$.

\subsubsection{Bus Rapid Transit Station Proximity and Worker Change}

The world's second oldest BRT system—-behind Curitiba, Brazil—is Pittsburgh. Its system was initiated in 1977 with three lines operating by 1990. It has been only since 2004 that new BRT systems have been added. In this subsection we start by reviewing the link between change in Transit Region workers and Pittsburgh's BRT system, then present findings for systems launched during the pre-recession, Great Recession, and post-recession periods.

\subsubsection{The Pittsburgh Pioneer}

Pittsburgh's BRT system predates our study period by nearly a quarter century and the Great Recession by more than 30 years. We surmise that the market will have had plenty of time to assess advantages (or disadvantages) of locating firms proximate to BRT stations. Results seem to confirm this as we find:

- Before the recession, more than half the new workers formed in the Transit Region (Allegheny County) located within 0.50-mile of BRT stations; 
- During the Great Recession, where the Transit Region actually added more workers than during the pre-recession period, three-quarters of all new workers located within 0.25-mile of BRT stations; and

- Whereas the Transit Region lost workers during the post-recession period, nearly 6,000 new workers located within the innermost (0.125-mile) distance band and nearly 8,000 workers with the 0.25-mile distance band.

There is an impressive association between new workers and BRT station proximity. This is not necessarily causal, however, as locations near such centers as downtowns, universities and other institutions have inherent location advantages. Nonetheless, it seems that locations away from BRT stations may be inherently less attractive.

Table 3.7: Change in Total Workers by Time Period, Pittsburgh BRT System

\begin{tabular}{|c|c|c|c|c|c|c|c|c|c|}
\hline $\begin{array}{c}\text { Distance } \\
\text { Band }\end{array}$ & $\begin{array}{c}\text { Transit } \\
\text { Region } \\
\text { UA } \\
\text { (sq.mi.) }\end{array}$ & $\begin{array}{c}\text { Distance } \\
\text { Band } \\
\text { UA } \\
\text { (sq.mi.) }\end{array}$ & $\begin{array}{c}\text { Distance } \\
\text { Band } \\
\text { Share of } \\
\text { Transit } \\
\text { Region } \\
\text { UA } \\
\end{array}$ & $\begin{array}{c}\text { Station } \\
\text { Area } \\
\text { Worker } \\
\text { Change } \\
2004- \\
2007 \\
\end{array}$ & $\begin{array}{c}\text { Share of } \\
\text { Regional } \\
\text { Worker } \\
\text { Change } \\
2004- \\
2007 \\
\end{array}$ & $\begin{array}{c}\text { Station } \\
\text { Area } \\
\text { Worker } \\
\text { Change } \\
2008- \\
2011 \\
\end{array}$ & $\begin{array}{c}\text { Share of } \\
\text { Regional } \\
\text { Worker } \\
\text { Change } \\
2008- \\
2011 \\
\end{array}$ & $\begin{array}{c}\text { Station } \\
\text { Area } \\
\text { Worker } \\
\text { Change } \\
2012- \\
2015 \\
\end{array}$ & $\begin{array}{c}\text { Share of } \\
\text { Regional } \\
\text { Worker } \\
\text { Change } \\
2012- \\
2015 \\
\end{array}$ \\
\hline $\begin{array}{c}0.00- \\
0.125 \\
\end{array}$ & 588.3 & 30.7 & $5.2 \%$ & 2,640 & $16.6 \%$ & 16,754 & $64.5 \%$ & 5,899 & na-100\% \\
\hline $\begin{array}{c}0.125- \\
0.25\end{array}$ & 588.3 & 36.9 & $6.3 \%$ & 911 & $5.7 \%$ & 2,765 & $10.6 \%$ & 1,796 & na-100\% \\
\hline $\begin{array}{c}0.00- \\
0.25 \\
\end{array}$ & 588.3 & 67.6 & $11.5 \%$ & 3,551 & $22.3 \%$ & 19,519 & $75.1 \%$ & 7,695 & na- $100 \%$ \\
\hline $\begin{array}{c}0.25- \\
0.50 \\
\end{array}$ & 588.3 & 66.1 & $11.2 \%$ & 4,870 & $30.6 \%$ & 2,795 & $10.8 \%$ & $(5,043)$ & na-0\%\% \\
\hline $\begin{array}{c}0.00- \\
0.50\end{array}$ & 588.3 & 133.7 & $22.7 \%$ & 8,421 & $52.9 \%$ & 22,314 & $85.9 \%$ & 2,652 & na-100\% \\
\hline $\begin{array}{l}\text { Transit } \\
\text { period }\end{array}$ & & & & 15,905 & & 25,989 & & $(4,885)$ & \\
\hline
\end{tabular}

Note: "na-100\%" means workers were added to the respective distance band though the Transit Region as a whole lost workers while "na-0\%" means workers were lost both within the distance band and the Transit Region.

Z-scores show that all differences are statistically significant at $\mathrm{p}<0.05$.

\subsubsection{Pre-Recession BRT Systems}

During the pre-recession period, America’s next four BRT systems were launched, including:

- Eugene-Springfield 2007

- Kansas City 2005

- $\quad 2004$

- Stockton 2007 
Table 3.8 reports results for this group. One trend stands out clearly: The innermost (0.125-mile) distance band has accounted for $20 \%$ to $30 \%$ of the new workers in these Transit Regions before and after the Great Recession, and collectively added nearly 70,000 workers in that band during the Great Recession when those regions lost more than 40,000 workers.

Table 3.8: Change in Total Workers by Time Period, Pre-Recession BRT Systems

\begin{tabular}{|c|c|c|c|c|c|c|c|c|c|}
\hline $\begin{array}{c}\text { Distance } \\
\text { Band } \\
\end{array}$ & $\begin{array}{c}\text { Transit } \\
\text { Region } \\
\text { UA } \\
\text { (sq.mi.) }\end{array}$ & $\begin{array}{c}\text { Distance } \\
\text { Band } \\
\text { UA } \\
\text { (sq.mi.) } \\
\end{array}$ & $\begin{array}{c}\text { Distance } \\
\text { Band } \\
\text { Share of } \\
\text { Transit } \\
\text { Region } \\
\text { UA } \\
\end{array}$ & $\begin{array}{c}\text { Station } \\
\text { Area } \\
\text { Worker } \\
\text { Change } \\
\text { 2004- } \\
2007 \\
\end{array}$ & $\begin{array}{c}\text { Share of } \\
\text { Regional } \\
\text { Worker } \\
\text { Change } \\
\text { 2004- } \\
2007 \\
\end{array}$ & $\begin{array}{c}\text { Station } \\
\text { Area } \\
\text { Worker } \\
\text { Change } \\
\text { 2008- } \\
2011 \\
\end{array}$ & $\begin{array}{c}\text { Share of } \\
\text { Regional } \\
\text { Worker } \\
\text { Change } \\
\text { 2008- } \\
2011 \\
\end{array}$ & $\begin{array}{c}\text { Station } \\
\text { Area } \\
\text { Worker } \\
\text { Change } \\
2012- \\
2015 \\
\end{array}$ & $\begin{array}{c}\text { Share of } \\
\text { Regional } \\
\text { Worker } \\
\text { Change } \\
2012- \\
2015 \\
\end{array}$ \\
\hline $\begin{array}{l}0.00- \\
0.125 \\
\end{array}$ & 870.4 & 20.5 & $2.4 \%$ & 32,467 & $22.8 \%$ & 67,310 & na-100\% & 36,791 & $29.9 \%$ \\
\hline $\begin{array}{c}0.125- \\
0.25 \\
\end{array}$ & 870.4 & 33.4 & $3.8 \%$ & 3,534 & $2.5 \%$ & $(21,395)$ & na-0\% & $(1,964)$ & $-1.6 \%$ \\
\hline $\begin{array}{c}0.00- \\
0.25 \\
\end{array}$ & 870.4 & 53.9 & $6.2 \%$ & 36,001 & $25.3 \%$ & 45,915 & na-100\% & 34,827 & $28.3 \%$ \\
\hline $\begin{array}{c}0.25- \\
0.50 \\
\end{array}$ & 870.4 & 55.5 & $6.4 \%$ & 6,105 & $4.3 \%$ & $(14,140)$ & na- $0 \%$ & 615 & $0.5 \%$ \\
\hline $\begin{array}{c}0.00- \\
0.50 \\
\end{array}$ & 870.4 & 114.9 & $13.2 \%$ & 42,106 & $29.5 \%$ & 31,775 & na-100\% & 35,442 & $28.8 \%$ \\
\hline $\begin{array}{l}\text { Transit Re } \\
\text { period }\end{array}$ & $n$ worke & ange wl & & 142,491 & & $(44,079)$ & & 123,040 & \\
\hline
\end{tabular}

Note: "na-100\%" means workers were added to the respective distance band though the Transit Region as a whole lost workers while "na- $0 \%$ " means workers were lost both within the distance band and the Transit Region.

Z-scores show that all differences are statistically significant at $\mathrm{p}<0.05$.

\subsubsection{Great Recession BRT Systems}

These six BRT systems were added during or very shortly after the Great Recession:

- Cleveland

- Nashville

- Phoenix

- Reno

- $\quad$ Salt Lake City

- Seattle
2008

2009

$$
2009
$$

2010

2008

2010

Table 3.9 shows that trends mostly mimic those for the pre-recession systems, notably that while the innermost (0.125-mile) distance band gained workers during the Great Recession, the rest of these Transit Regions lost workers. Also, during the post-recession 
period, the innermost (0.125-mile) distance band gained more workers than the two earlier study periods combined, accounting for about a sixth (14\%) of their Transit Regions’ worker growth.

Table 3.9: Change in Total Workers by Time Period, Great Recession BRT Systems

\begin{tabular}{|c|c|c|c|c|c|c|c|c|c|}
\hline $\begin{array}{c}\text { Distance } \\
\text { Band } \\
\end{array}$ & $\begin{array}{c}\text { Transit } \\
\text { Region } \\
\text { UA } \\
\text { (sq.mi.) }\end{array}$ & $\begin{array}{c}\text { Distance } \\
\text { Band } \\
\text { UA } \\
\text { (sq.mi.) }\end{array}$ & $\begin{array}{c}\text { Distance } \\
\text { Band } \\
\text { Share of } \\
\text { Transit } \\
\text { Region } \\
\text { UA } \\
\end{array}$ & $\begin{array}{c}\text { Station } \\
\text { Area } \\
\text { Worker } \\
\text { Change } \\
2004- \\
2007 \\
\end{array}$ & $\begin{array}{c}\text { Share of } \\
\text { Regional } \\
\text { Worker } \\
\text { Change } \\
2004- \\
2007 \\
\end{array}$ & $\begin{array}{c}\text { Station } \\
\text { Area } \\
\text { Worker } \\
\text { Change } \\
2008- \\
2011 \\
\end{array}$ & $\begin{array}{c}\text { Share of } \\
\text { Regional } \\
\text { Worker } \\
\text { Change } \\
2008- \\
2011 \\
\end{array}$ & $\begin{array}{c}\text { Station } \\
\text { Area } \\
\text { Worker } \\
\text { Change } \\
2012- \\
2015 \\
\end{array}$ & $\begin{array}{c}\text { Share of } \\
\text { Regional } \\
\text { Worker } \\
\text { Change } \\
2012- \\
2015 \\
\end{array}$ \\
\hline $\begin{array}{l}0.00- \\
0.125 \\
\end{array}$ & $3,048.7$ & 20.5 & $0.7 \%$ & 25,786 & $8.2 \%$ & 5,794 & na- $100 \%$ & 41,122 & $14.0 \%$ \\
\hline $\begin{array}{c}0.125- \\
0.25\end{array}$ & $3,048.7$ & 37.1 & $1.2 \%$ & 17,898 & $5.7 \%$ & $(11,381)$ & na- $0 \%$ & 11,124 & $3.8 \%$ \\
\hline $\begin{array}{c}0.00- \\
0.25 \\
\end{array}$ & $3,048.7$ & 57.6 & $1.9 \%$ & 43,684 & $13.9 \%$ & $(5,587)$ & na- $0 \%$ & 52,246 & $17.8 \%$ \\
\hline $\begin{array}{c}0.25- \\
0.50\end{array}$ & $3,048.7$ & 84.7 & $2.8 \%$ & $(1,781)$ & $-0.6 \%$ & 2,168 & na- $0 \%$ & $(13,606)$ & $-4.6 \%$ \\
\hline $\begin{array}{l}0.00- \\
0.50 \\
\end{array}$ & $3,048.7$ & 147.1 & $4.8 \%$ & 41,903 & $13.3 \%$ & $(3,419)$ & na- $0 \%$ & 38,640 & $13.1 \%$ \\
\hline $\begin{array}{l}\text { Transit } \\
\text { period }\end{array}$ & 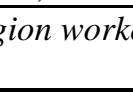 & & & 314,580 & & $(47,674)$ & & 294,177 & \\
\hline
\end{tabular}

Note: "na-100\%" means workers were added to the respective distance band though the Transit Region as a whole lost workers while "na-0\%" means workers were lost both within the distance band and the Transit Region.

Z-scores show that all differences are statistically significant at $\mathrm{p}<0.05$.

\subsubsection{Post-Recession BRT Systems}

During our post-recession study period, 2012-2015, three BRT systems opened:

- San Antonio

- San Diego

- Washington DC
2012

2014

2014

However, as LEHD data are not available for the District of Columbia, we consider only San Antonio and San Diego, results for which are reported in Table 3.10. We note that during the pre-recession period, when these systems were not operating though perhaps in the planning stages, the distance bands to 0.50-mile lost workers even though the Transit Regions - the robust, growing economies of San Antonio and San Diego-gained tens of thousands of workers. This trend reversed during the Great Recession-when these systems were under development with the market being cognizant of location opportunities - a post-recession periods. Indeed, during the Great Recession, the 0.25mile distance band accounted for more than $40 \%$ of the new workers locating in the Transit Region. While the share fell to about 14\% during the post-recession period, more 
than 20,000 workers located near BRT stations or two-thirds more than during the Great Recession.

Table 3.10: Change in Total Workers by Time Period, Great Recession BRT Systems

\begin{tabular}{|c|c|c|c|c|c|c|c|c|c|}
\hline $\begin{array}{c}\text { Distance } \\
\text { Band } \\
\end{array}$ & $\begin{array}{c}\text { Transit } \\
\text { Region } \\
\text { UA } \\
\text { (sq.mi.) }\end{array}$ & $\begin{array}{c}\text { Distance } \\
\text { Band } \\
\text { UA } \\
\text { (sq.mi.) }\end{array}$ & $\begin{array}{c}\text { Distance } \\
\text { Band } \\
\text { Share of } \\
\text { Transit } \\
\text { Region } \\
\text { UA } \\
\end{array}$ & $\begin{array}{c}\text { Station } \\
\text { Area } \\
\text { Worker } \\
\text { Change } \\
2004- \\
2007 \\
\end{array}$ & $\begin{array}{c}\text { Share of } \\
\text { Regional } \\
\text { Worker } \\
\text { Change } \\
2004- \\
2007 \\
\end{array}$ & $\begin{array}{c}\text { Station } \\
\text { Area } \\
\text { Worker } \\
\text { Change } \\
2008- \\
2011 \\
\end{array}$ & $\begin{array}{c}\text { Share of } \\
\text { Regional } \\
\text { Worker } \\
\text { Change } \\
2008- \\
2011 \\
\end{array}$ & $\begin{array}{c}\text { Station } \\
\text { Area } \\
\text { Worker } \\
\text { Change } \\
\text { 2012- } \\
2015 \\
\end{array}$ & $\begin{array}{c}\text { Share of } \\
\text { Regional } \\
\text { Worker } \\
\text { Change } \\
2012- \\
2015 \\
\end{array}$ \\
\hline $\begin{array}{l}0.00- \\
0.125 \\
\end{array}$ & $1,266.4$ & 6.5 & $0.5 \%$ & $(10,265)$ & $-14.2 \%$ & 14,389 & $25.5 \%$ & 20,383 & $14.4 \%$ \\
\hline $\begin{array}{c}0.125- \\
0.25 \\
\end{array}$ & $1,266.4$ & 11.6 & $0.9 \%$ & 757 & $1.0 \%$ & 8,909 & $15.8 \%$ & $(21)$ & $-0.0 \%$ \\
\hline $\begin{array}{c}0.00- \\
0.25 \\
\end{array}$ & $1,266.4$ & 18.2 & $1.4 \%$ & $(9,508)$ & $-13.2 \%$ & 23,298 & $41.2 \%$ & 20,362 & $14.4 \%$ \\
\hline $\begin{array}{c}0.25- \\
0.50 \\
\end{array}$ & $1,266.4$ & 27.1 & $2.1 \%$ & 1,016 & $1.4 \%$ & $(1,387)$ & $-2.5 \%$ & $(3,331)$ & $-2.4 \%$ \\
\hline $\begin{array}{c}0.00- \\
0.50 \\
\end{array}$ & $1,266.4$ & 45.2 & $3.6 \%$ & $(8,492)$ & $-11.8 \%$ & 21,911 & $38.8 \%$ & 17,031 & $12.0 \%$ \\
\hline $\begin{array}{l}\text { Transit Re } \\
\text { period }\end{array}$ & ion work & ange $w$ & & 72,112 & & 56,514 & & 141,499 & \\
\hline
\end{tabular}

Z-scores show that all differences are statistically significant at $\mathrm{p}<0.05$.

\subsubsection{Newest BRT Systems}

During our analysis, several new BRT systems became operational. These are systems we aim to include in future research:

- Albuquerque

- Minneapolis

- San Jose
2017

2016

2017

Nonetheless, they are included in our market rent research (see Chapter 2). 


\subsubsection{Streetcar Transit Station Proximity and Worker Change}

As alluded to earlier, modern streetcars are the newest forms of FRT transit arising across the U.S. We sort them by those commencing operations before or after the Great Recession.

\subsubsection{Pre-Recession SCT Systems}

After Portland's success, several SCT systems were built during the 2000s before the Great Recession, including:

- $\quad$ Little Rock

- Portland

- Seattle

- Tacoma

- Tampa
2004

2001

2007

2003

2002

Two of these systems-Little Rock (connecting downtown to the Clinton Presidential Library) and Tampa (connecting downtown to historic districts) —are designed to serve mostly tourist needs. Though we include analysis for each system in the appendix, we exclude them from overall analysis here. We also exclude Tacoma from the overall analysis because it seems designed to only the downtown to the convention center and sports venues and, at 1.6 miles with just 6 stops, it is the smallest system in our study.

Table 3.11 presents results of our analysis.

Table 3.11: Change in Total Workers by Time Period, Pre-Recession SCT Systems

\begin{tabular}{|c|c|c|c|c|c|c|c|c|c|}
\hline $\begin{array}{c}\text { Distance } \\
\text { Band } \\
\end{array}$ & $\begin{array}{c}\text { Transit } \\
\text { Region } \\
\text { UA } \\
\text { (sq.mi.) }\end{array}$ & $\begin{array}{c}\text { Distance } \\
\text { Band } \\
\text { UA } \\
\text { (sq.mi.) }\end{array}$ & $\begin{array}{l}\text { Distance } \\
\text { Band } \\
\text { Share of } \\
\text { Transit } \\
\text { Region } \\
\text { UA } \\
\end{array}$ & $\begin{array}{c}\text { Station } \\
\text { Area } \\
\text { Worker } \\
\text { Change } \\
\text { 2004- } \\
2007 \\
\end{array}$ & $\begin{array}{c}\text { Share of } \\
\text { Regional } \\
\text { Worker } \\
\text { Change } \\
\text { 2004- } \\
2007 \\
\end{array}$ & $\begin{array}{c}\text { Station } \\
\text { Area } \\
\text { Worker } \\
\text { Change } \\
\text { 2008- } \\
2011 \\
\end{array}$ & $\begin{array}{c}\text { Share of } \\
\text { Regional } \\
\text { Worker } \\
\text { Change } \\
2008- \\
2011 \\
\end{array}$ & $\begin{array}{c}\text { Station } \\
\text { Area } \\
\text { Worker } \\
\text { Change } \\
2012- \\
2015 \\
\end{array}$ & $\begin{array}{c}\text { Share of } \\
\text { Regional } \\
\text { Worker } \\
\text { Change } \\
2012- \\
2015 \\
\end{array}$ \\
\hline $\begin{array}{c}0.00- \\
0.125 \\
\end{array}$ & 1,098 & 2.85 & $0.3 \%$ & 16,590 & $16.3 \%$ & $(12,723)$ & $-44.0 \%$ & 4,297 & $7.7 \%$ \\
\hline $\begin{array}{c}0.125- \\
0.25 \\
\end{array}$ & 1,098 & 3.73 & $0.3 \%$ & 5,641 & $5.5 \%$ & $(7,407)$ & $-25.6 \%$ & 6,599 & $11.8 \%$ \\
\hline $\begin{array}{c}0.00- \\
0.25 \\
\end{array}$ & 1,098 & 6.58 & $0.6 \%$ & 22,231 & $21.9 \%$ & $(20,130)$ & $-69.6 \%$ & 10,896 & $19.5 \%$ \\
\hline $\begin{array}{c}0.25- \\
0.50 \\
\end{array}$ & 1,098 & 7.22 & $0.7 \%$ & 9,286 & $9.1 \%$ & 26,206 & $90.5 \%$ & 1,344 & $2.4 \%$ \\
\hline $\begin{array}{c}0.00- \\
0.50\end{array}$ & 1,098 & 13.79 & $1.3 \%$ & 31,517 & $31.0 \%$ & 6,076 & $21.0 \%$ & 12,240 & $21.9 \%$ \\
\hline $\begin{array}{l}\text { Transit Re } \\
\text { period }\end{array}$ & 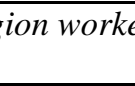 & lange $w$ & & 101,641 & & 28,941 & & 55,890 & \\
\hline
\end{tabular}

Z-scores show that all differences are statistically significant at $\mathrm{p}<0.05$. 
While these systems are associated with worker gains across all distance bands before and after the Great Recession, they are associated with losses during the recession even though their Transit Regions gained workers. We suspect one reason is that residential demand for locations near SCT stops began emerging in the middle 2000s with the effect of displacing workers, and during the Great Recession with weak economies albeit strong downtown residential demand, workers were further displaced. This may be the case especially with respect to downtown Portland and Seattle.

\subsubsection{Post-Recession SCT Systems}

After the Great Recession but during our study period, four additional SCT systems began operations:

- Atlanta

- Dallas

- $\quad$ Salt Lake City

- Tucson
2014

2015

2013

2014

Results are reported in Table 3.12. As planning, design and construction of these systems occurred substantially during and after the Great Recession, we compare outcomes during and afterward. During the Great Recession the areas that would become SCT stations added workers within the innermost (0.125-mile) distance band where their Transit Regions lost workers. During the post-recession period, more workers were added to this band though the share of total worker change was quite small. On the other hand, comprising just one-tenth of one percent of the Transit Region UA, the innermost (0,.125-mile) distance band accounted for $5.2 \%$ of the new workers, or a factor of 50 -to1. As we will see in Chapter 5, there appears to be competition between people and workers near SCT (and LRT) stations.

Table 3.12: Change in Total Workers by Time Period, Post-Recession SCT Systems

\begin{tabular}{|c|c|c|c|c|c|c|c|c|c|}
\hline $\begin{array}{c}\text { Distance } \\
\text { Band } \\
\end{array}$ & $\begin{array}{c}\text { Transit } \\
\text { Region } \\
\text { UA } \\
\text { (sq.mi.) }\end{array}$ & $\begin{array}{c}\text { Distance } \\
\text { Band } \\
\text { UA } \\
\text { (sq.mi.) }\end{array}$ & $\begin{array}{c}\text { Distance } \\
\text { Band } \\
\text { Share of } \\
\text { Transit } \\
\text { Region } \\
\text { UA } \\
\end{array}$ & $\begin{array}{c}\text { Station } \\
\text { Area } \\
\text { Worker } \\
\text { Change } \\
2004- \\
2007 \\
\end{array}$ & $\begin{array}{c}\text { Share of } \\
\text { Regional } \\
\text { Worker } \\
\text { Change } \\
2004- \\
2007 \\
\end{array}$ & $\begin{array}{c}\text { Station } \\
\text { Area } \\
\text { Worker } \\
\text { Change } \\
\text { 2008- } \\
2011 \\
\end{array}$ & $\begin{array}{c}\text { Share of } \\
\text { Regional } \\
\text { Worker } \\
\text { Change } \\
2008- \\
2011 \\
\end{array}$ & $\begin{array}{c}\text { Station } \\
\text { Area } \\
\text { Worker } \\
\text { Change } \\
2012- \\
2015 \\
\end{array}$ & $\begin{array}{c}\text { Share of } \\
\text { Regional } \\
\text { Worker } \\
\text { Change } \\
2012- \\
2015 \\
\end{array}$ \\
\hline $\begin{array}{l}\text { 0.00- } \\
0.125 \\
\end{array}$ & 1,788 & 2.51 & $0.1 \%$ & 24,571 & $12.8 \%$ & 10,758 & na-100\% & 13,115 & $5.2 \%$ \\
\hline $\begin{array}{c}0.125- \\
0.25 \\
\end{array}$ & 1,788 & 3.62 & $0.2 \%$ & $(4,501)$ & $-2.3 \%$ & $(12,684)$ & na- $0 \%$ & 1,162 & $0.5 \%$ \\
\hline $\begin{array}{c}0.00- \\
0.25 \\
\end{array}$ & 1,788 & 6.13 & $0.3 \%$ & 20,070 & $10.5 \%$ & $(1,926)$ & na-0\% & 14,277 & $5.6 \%$ \\
\hline $\begin{array}{c}0.25- \\
0.50 \\
\end{array}$ & 1,788 & 8.24 & $0.5 \%$ & $(2,511)$ & $-1.3 \%$ & $(9,332)$ & na- $0 \%$ & 2,289 & $0.9 \%$ \\
\hline $\begin{array}{c}0.00- \\
0.50 \\
\end{array}$ & 1,788 & 18.44 & $1.0 \%$ & 17,559 & $9.2 \%$ & $(11,258)$ & na-0\% & 16,566 & $6.5 \%$ \\
\hline
\end{tabular}


Transit Region worker change within period

\begin{tabular}{|l|l|l|l|l|}
\hline 191,818 & & $(19,014)$ & & 254,004 \\
\hline
\end{tabular}

Note: "na-100\%" means workers were added to the respective distance band though the Transit Region as a whole lost workers while "na- $0 \%$ " means workers were lost both within the distance band and the Transit Region.

Z-scores show that all differences are statistically significant at $\mathrm{p}<0.05$.

\subsubsection{Newest SCT Systems}

Several new SCTY systems became operational after our study period. Though we included these systems in our market rent research (see Chapter 2), we hope to add them in future economic development research:

- Cincinnati 2016

- New Orleans 2016

- Kansas City 2016

- Washington, DC 2016 


\subsubsection{Commuter Rail Transit Station Proximity and Worker Change}

CRT systems may be a largely forgotten or least under-appreciated element of FRT and land use planning at least until recent years. We identify two CRT eras: those built in the last quarter of the past century $-1{ }^{\text {st }}$ Generation, and those built since $2000-2^{\text {nd }}$ Generation. Although we considered dividing the $2^{\text {nd }}$ Generation into before, during and after the Great Recession, trends were roughly the same between them.

\subsubsection{1 $\quad 1^{\text {st }}$ Generation CRT Systems}

While there have been commuter rail systems operating throughout the Northeast and the Great Lakes states for decades, our focus is on newer systems serving Sunbelt and western metropolitan areas. These include:

- Dallas-Fort Worth

- $\quad$ Miami Tri-Rail

- Minneapolis

- San Diego

- San Jose-Stockton

- Seattle-Tacoma
1996

1989

1995

1998

2000

We present analysis results in Table 3.13. We find that for the most part CRT station areas follow the economies of their Transit Regions; as those regions grow so do workers near CRT stations but as regions decline so do workers near CRT stations. Nonetheless, we detect a strong market response to locating in the 0.25-mile to 0.50-mile distance bands - in contrast to Chapter 5 where we find surprisingly strong post-recession residential demand nearer CRT stations. Among the $1^{\text {st }}$ Generation CRT systems, during the post-recession period, CRT station areas between 0.25- and 0.50-mile of CRT stations accounted for nearly $6 \%$ of the increase in Transit Region workers yet they comprised only six-tenths of one percent of the Transit Region UA. Put differently, 10 times more workers located within this distance band than the land area comprises as a share of Transit Region UA. When combined with the closer (0.25-mile) distance band, the first half-mile from CRT stations accounted for more than 9\% of Transit Region worker growth during the post-recession period. 
Table 3.13: Change in Total Workers by Time Period, $1^{\text {st }}$ Generation CRT Systems

\begin{tabular}{|c|c|c|c|c|c|c|c|c|c|}
\hline $\begin{array}{c}\text { Distance } \\
\text { Band } \\
\end{array}$ & $\begin{array}{c}\text { Transit } \\
\text { Region } \\
\text { UA } \\
\text { (sq.mi.) }\end{array}$ & $\begin{array}{c}\text { Distance } \\
\text { Band } \\
\text { UA } \\
\text { (sq.mi.) } \\
\end{array}$ & $\begin{array}{c}\text { Distance } \\
\text { Band } \\
\text { Share of } \\
\text { Transit } \\
\text { Region } \\
\text { UA } \\
\end{array}$ & $\begin{array}{c}\text { Station } \\
\text { Area } \\
\text { Worker } \\
\text { Change } \\
\text { 2004- } \\
2007 \\
\end{array}$ & $\begin{array}{c}\text { Share of } \\
\text { Regional } \\
\text { Worker } \\
\text { Change } \\
2004- \\
2007 \\
\end{array}$ & $\begin{array}{c}\text { Station } \\
\text { Area } \\
\text { Worker } \\
\text { Change } \\
2008- \\
2011 \\
\end{array}$ & $\begin{array}{c}\text { Share of } \\
\text { Regional } \\
\text { Worker } \\
\text { Change } \\
2008- \\
2011 \\
\end{array}$ & $\begin{array}{c}\text { Station } \\
\text { Area } \\
\text { Worker } \\
\text { Change } \\
2012- \\
2015 \\
\end{array}$ & $\begin{array}{c}\text { Share of } \\
\text { Regional } \\
\text { Worker } \\
\text { Change } \\
2012- \\
2015 \\
\end{array}$ \\
\hline $\begin{array}{l}0.00- \\
0.125 \\
\end{array}$ & $5,650.0$ & 3.1 & $0.1 \%$ & 16,963 & $3.0 \%$ & $(2,308)$ & $-1.2 \%$ & 15,658 & $2.1 \%$ \\
\hline $\begin{array}{c}0.125- \\
0.25 \\
\end{array}$ & $5,650.0$ & 8.8 & $0.2 \%$ & 6,483 & $1.1 \%$ & $(10,276)$ & $-5.2 \%$ & 9,790 & $1.3 \%$ \\
\hline $\begin{array}{c}0.00- \\
0.25 \\
\end{array}$ & $5,650.0$ & 11.9 & $0.2 \%$ & 23,446 & $4.1 \%$ & $(12,584)$ & $-6.3 \%$ & 25,448 & $3.4 \%$ \\
\hline $\begin{array}{c}0.25- \\
0.50 \\
\end{array}$ & $5,650.0$ & 34.0 & $0.6 \%$ & $(10,758)$ & $-1.9 \%$ & $(4,903)$ & $-2.5 \%$ & 43,735 & $5.8 \%$ \\
\hline $\begin{array}{c}0.00- \\
0.50\end{array}$ & $5,650.0$ & 46.0 & $0.8 \%$ & 12,688 & $2.2 \%$ & $(17,487)$ & $-8.8 \%$ & 69,183 & $9.1 \%$ \\
\hline \multicolumn{4}{|c|}{ Transit Region } & 571,210 & & 198,189 & & 756,710 & \\
\hline
\end{tabular}

Z-scores show that all differences are statistically significant at $\mathrm{p}<0.05$.

\subsubsection{2 $\quad 2^{\text {nd }}$ Generation CRT Systems}

In all, the $2^{\text {nd }}$ Generation is comprised of six CRT systems including:

- Albuquerque 2006

- Austin 2010

- Nashville 2006

- Orlando 2014

- Portland 2009

- $\quad$ Salt Lake City 2008

Table 3.14 shows substantially comparable overall attraction of workers within 0.50 mile of CRT stations as seen for $1^{\text {st }}$ Generation CRT systems since the Great Recession. This space accounted for nearly a quarter (22.7\%) of their Transit Regions' change in workers with nearly $10 \%$ locating in the first (0.125-mile) distance band. The main difference is that $1^{\text {st }}$ Generation systems had higher attraction in the $0.25-0.50$-mile distance band while the $2^{\text {nd }}$ Generation saw higher attraction in from the transit station to the 0.25 -mile distance band. Otherwise, then overall trends between these systems for all three study periods are about the same. 
Table 3.14: Change in Total Workers by Time Period, $2^{\text {nd }}$ Generation CRT Systems

\begin{tabular}{c|c|r|r|r|r|r|c|c|c}
\hline $\begin{array}{c}\text { Distance } \\
\text { Band }\end{array}$ & $\begin{array}{c}\text { Transit } \\
\text { Region } \\
\text { UA } \\
\text { (sq.mi.) }\end{array}$ & $\begin{array}{c}\text { Distance } \\
\text { Band } \\
\text { UA } \\
\text { (sq.mi.) }\end{array}$ & $\begin{array}{c}\text { Distance } \\
\text { Band } \\
\text { Share of } \\
\text { Transit } \\
\text { Region } \\
\text { UA }\end{array}$ & $\begin{array}{c}\text { Station } \\
\text { Area } \\
\text { Worker } \\
\text { Change } \\
\mathbf{2 0 0 4 -} \\
\mathbf{2 0 0 7}\end{array}$ & $\begin{array}{c}\text { Share of } \\
\text { Regional } \\
\text { Worker } \\
\text { Change } \\
\mathbf{2 0 0 4 -} \\
\mathbf{2 0 0 7}\end{array}$ & $\begin{array}{c}\text { Station } \\
\text { Area } \\
\text { Worker } \\
\text { Change } \\
\mathbf{2 0 0 8 -} \\
\mathbf{2 0 1 1}\end{array}$ & $\begin{array}{c}\text { Share of } \\
\text { Regional } \\
\text { Worker } \\
\text { Change } \\
\mathbf{2 0 0 8 -} \\
\mathbf{2 0 1 1}\end{array}$ & $\begin{array}{c}\text { Station } \\
\text { Area } \\
\text { Worker } \\
\text { Change } \\
\mathbf{2 0 1 2 -} \\
\mathbf{2 0 1 5}\end{array}$ & $\begin{array}{c}\text { Share of } \\
\text { Regional } \\
\text { Worker } \\
\text { Change } \\
\mathbf{2 0 1 2 -} \\
\mathbf{2 0 1 5}\end{array}$ \\
\hline $\begin{array}{c}\mathbf{0 . 0 0 -} \\
\mathbf{0 . 1 2 5}\end{array}$ & $3,023.1$ & 3.0 & $0.1 \%$ & 5,633 & $1.9 \%$ & $(14,193)$ & $-27.1 \%$ & 13,359 & $3.9 \%$ \\
\hline $\begin{array}{c}\mathbf{0 . 1 2 5}- \\
\mathbf{0 . 2 5}\end{array}$ & $3,023.1$ & 8.9 & $0.3 \%$ & 3,846 & $1.3 \%$ & $(2,594)$ & $-5.0 \%$ & 9,031 & $2.7 \%$ \\
\hline $\begin{array}{l}\mathbf{0 . 0 0}- \\
\mathbf{0 . 2 5}\end{array}$ & $3,023.1$ & 11.8 & $0.4 \%$ & 9,479 & $3.3 \%$ & $(16,787)$ & $-32.1 \%$ & 22,390 & $6.6 \%$ \\
\hline $\begin{array}{l}\mathbf{0 . 2 5}- \\
\mathbf{0 . 5 0}\end{array}$ & $3,023.1$ & 34.2 & $1.1 \%$ & 18,373 & $6.3 \%$ & $(8,905)$ & $-17.0 \%$ & 4,885 & $1.4 \%$ \\
\hline $\mathbf{0 . 0 0}$ \\
$\mathbf{0 . 5 0}$
\end{tabular}

Z-scores show that all differences are statistically significant at $\mathrm{p}<0.05$.

For more detailed data, we refer the reader to the Data Appendix for the Variation of Economic Development with Respect to Fixed Route Transit Station Proximity Before, During and After the Great Recession.

\subsection{OVERALL IMPLICATIONS FOR TRANSIT AND LAND USE PLANNING}

This is the nation's first longitudinal study that explores the link between the change in total workers and FRT station proximity. It is especially useful to transit and land use planners since it:

- Includes all the major fixed route transit (FRT) options outside the Northeast, Chicago, and Los Angeles where a complex web of transit services may not allow researchers to clearly associate specific kinds of FRT systems with outcomes;

- Begins with a period that is arguably when the nation sprawled the most, the early 2000s to before the Great Recession (see Nelson 2013);

- Includes the Great Recession and years immediately afterward thereby allowing for a quasi-natural experiment that assesses what happens to a system when an external event disrupts the status quo; and

- Explores how the distribution of workers changes after such a major external event, and the extent to which FRT station proximity is associated with that change.

Some overall trends are evident. For instance, during the early 2000s, many Transit Regions lost workers from FRT station to 0.50-mile outward, especially with respect to newer FRT systems. The Great Recession may have stopped the outward spread of workers but it also reduced growth so in many cases FRT station areas continued to lose workers though in many others the 
hemorrhaging had slowed, if not reversed. In some situations, especially among $1^{\text {st }}$ and $2^{\text {nd }}$ generation light rail systems, station areas gained workers. The post-recession period saw what we consider a reset in how the market responds to FRT station proximity. In most cases, workers increased in station areas, often reversing trends seen during the Great Recession if not before. In some cases, stations accounted for all a Transit Region's worker growth.

We provide an overall perspective of the link between FRT station areas and change in Transit Region workers during the post-recession period in Table 3.15. We choose this period over others for three reasons. First, America is unlikely to see the kind of massive urban sprawl in the future as it saw during the early 2000s, even if suburbia still accounts for two-third or more of all new development (Nelson 2006). Second, the Great Recession-being the worst economic downturn in the US since the Great Depression—is unlikely to repeat (see Nelson et al. 2017). Third, it is the most recent period that may better reflect current and emerging market conditions than prior periods.

Two implications stand out. First, the innermost (0.125-mile) distance bands for LRT, BRT and SCT stations absorbed large shares of the growth in workers during the period 2012-2015. On the other hand, LRT systems gained an even larger share in the 0.25-0.50 mile distance band. In contrast, the $0.25-0.50$ mile distance band did not perform for BRT (which was negative) or SCT systems. CRT systems performed less well but outcomes are not trivial; nearly $9 \%$ of the total share of new CRT Transit Region workers were attracted to areas within 0.50 mile of CRT transit stations. 
Table 3.15: Post-Recession Share of Transit Region Worker Change by Distance Band and Ratio of Worker Share to Distance Band UA Share of Transit Region UA

\begin{tabular}{|c|c|c|c|c|c|c|c|c|c|c|c|c|}
\hline $\begin{array}{c}\text { Distance } \\
\text { Band, } \\
\text { Mile }\end{array}$ & $\begin{array}{c}\text { LRT } \\
\text { Distance } \\
\text { Band } \\
\text { Share of } \\
\text { Transit } \\
\text { Region } \\
\text { UA }\end{array}$ & $\begin{array}{c}\text { LRT-- } \\
\text { Share of } \\
\text { Regional } \\
\text { Worker } \\
\text { Change } \\
2012- \\
2015\end{array}$ & $\begin{array}{c}\text { LRT-- } \\
\text { Ratio of } \\
\text { Worker } \\
\text { Change } \\
\text { to } \\
\text { Distance } \\
\text { Band } \\
\text { UA }\end{array}$ & $\begin{array}{c}\text { BRT } \\
\text { Distance } \\
\text { Band } \\
\text { Share of } \\
\text { Transit } \\
\text { Region } \\
\text { UA }\end{array}$ & $\begin{array}{c}\text { BRT-- } \\
\text { Share of } \\
\text { Regional } \\
\text { Worker } \\
\text { Change } \\
2012- \\
2015\end{array}$ & $\begin{array}{c}\text { BRT-- } \\
\text { Ratio of } \\
\text { Worker } \\
\text { Change } \\
\text { to } \\
\text { Distance } \\
\text { Band } \\
\text { UA }\end{array}$ & $\begin{array}{c}\text { SCT } \\
\text { Distance } \\
\text { Band } \\
\text { Share of } \\
\text { Transit } \\
\text { Region } \\
\text { UA }\end{array}$ & $\begin{array}{c}\text { SCT-- } \\
\text { Share of } \\
\text { Regional } \\
\text { Worker } \\
\text { Change } \\
2012- \\
2015\end{array}$ & $\begin{array}{c}\text { SCT-- } \\
\text { Ratio of } \\
\text { Worker } \\
\text { Change } \\
\text { to } \\
\text { Distance } \\
\text { Band } \\
\text { UA }\end{array}$ & $\begin{array}{c}\text { CRT } \\
\text { Distance } \\
\text { Band } \\
\text { Share of } \\
\text { Transit } \\
\text { Region } \\
\text { UA }\end{array}$ & $\begin{array}{c}\text { CRT-- } \\
\text { Share of } \\
\text { Regional } \\
\text { Worker } \\
\text { Change } \\
2012- \\
2015\end{array}$ & $\begin{array}{c}\text { CRT-- } \\
\text { Ratio of } \\
\text { Worker } \\
\text { Change } \\
\text { to } \\
\text { Distance } \\
\text { Band } \\
\text { UA }\end{array}$ \\
\hline $\begin{array}{l}0.00- \\
0.125 \\
\end{array}$ & $0.3 \%$ & $4.9 \%$ & 14.0 & $1.4 \%$ & $18.8 \%$ & 13.9 & $0.2 \%$ & $5.6 \%$ & 30.3 & $0.1 \%$ & $2.6 \%$ & 38.1 \\
\hline $\begin{array}{c}0.125- \\
0.25 \\
\end{array}$ & $0.9 \%$ & $3.6 \%$ & 4.2 & $2.1 \%$ & $2.0 \%$ & 1.0 & $0.3 \%$ & $2.5 \%$ & 9.8 & $0.2 \%$ & $1.7 \%$ & 8.4 \\
\hline $\begin{array}{c}0.00- \\
0.25 \\
\end{array}$ & $1.2 \%$ & $8.5 \%$ & 7.1 & $3.4 \%$ & $20.8 \%$ & 6.1 & $0.4 \%$ & $8.1 \%$ & 18.4 & $0.3 \%$ & $4.4 \%$ & 16.0 \\
\hline $\begin{array}{c}0.25- \\
0.50\end{array}$ & $2.4 \%$ & $9.2 \%$ & 3.9 & $4.0 \%$ & $-3.9 \%$ & -1.0 & $0.5 \%$ & $1.2 \%$ & 2.2 & $0.8 \%$ & $4.4 \%$ & 5.6 \\
\hline $\begin{array}{c}0.00- \\
0.50\end{array}$ & $3.5 \%$ & $17.7 \%$ & 5.0 & $7.6 \%$ & $16.9 \%$ & 2.2 & $1.1 \%$ & $9.3 \%$ & 8.3 & $1.1 \%$ & $8.8 \%$ & 8.3 \\
\hline
\end{tabular}


Second, the ratio is workers absorbed compared to FRT station area band UAs (urban areas) is impressive. For instance, despite accounting for only 1.4\% of the BRT Transit Region's UA (urban area), the innermost (0.125-mile) BRT distance band absorbed 18.8\% of the Transit Region's workers between 2012 and 2015. In other words, workers were absorbed at a ratio of 13.9 times the land area for that distance band.

This leads to certain interpretations:

- For LRT systems, the innermost (0.125-mile) distance band comprises just $0.3 \%$ of the Transit Region urban area (UA) (the current Census term for urbanized land) but accounted for $4.9 \%$ of the new workers, or a ratio of 14.0 times. Over one-half $(0.50)$ mile, LRT systems accounted for $17.7 \%$ of new Transit Regions’ workers on only 3.5\% of the UA - a ratio of 5.0 times. For transit and land use planning purposes, it would seem prudent to facilitate worker growth within at least one-half $(0.05)$ mile of LRT transit stations.

- $\quad$ BRT systems absorbed $18.8 \%$ of the new Transit Region workers on just $1.4 \%$ of the UA or a ratio of 13.9. However, there appears to be a substantial reduction in worker absorption beyond one-quarter (0.25) mile. The area within one-quarter (0.25) mile of BRT stations may be the economic development threshold for BRT and land use planning.

- Our analysis indicates that SCT systems absorbed 5.6\% of their Transit Regions' workers in the first (0.125-mile) distance band on just $0.2 \%$ of the Transit Region UA-a ratio of 30.3. However, absorption appears to peak after one-quarter $(0.25)$ mile were $8.1 \%$ of the Transit Regions' new workers located, on just $0.4 \%$ of the Transit Regions' UA or a ratio of 18.4. It appears for transit and land-use planning purposes that the first quarter $(\mathbf{0 . 2 5})$ mile from SCT stations may generate the best results.

- $\quad$ As we implied in Chapter 2 and will note in late chapters, CRT systems may be underappreciated for their potential to accommodate new workers and people. In Table ES.3 we find that CRT stations attracted $2.6 \%$ of their Transit Regions' new workers on just $0.1 \%$ of the Transit Region UA, a ratio of 38.1. We also find substantial attractiveness to economic development to at least one-half (0.50) mile from CRT stations, which is our recommended area for transit and land use planning for economic development purposes.

One of these themes - that areas near transit stations absorb multiple times more workers than the Transit Region urban area-will recur in other chapters.

We have noted earlier that cause-and-effect relationships are not established. This means that we cannot say that if a community launches a BRT system it will find that $18.8 \%$ of all new Transit Region workers will migrate to the innermost (0.125 mile) distance band or even that the BRT system per se will create workers. For one thing, these systems are planned to serve areas of highest potential ridership that in large part are also based on where the workers are. Land use planning also tends to favor more development near stations, including being more predisposed to granting planning and zoning approvals to increase development near FRT stations. Indeed, 
proposals for economic development opportunities farther away but still within walking distance of FRT stations may be denied permits.

Yet, this begs the question: if markets—in this case firms hiring workers—do not value proximity to FRT stations, they would not concentrate around them in the first place. According to location theory, firms are attracted to these kinds of locations because market, labor, and other forms of accessibility are improved.

The kinds of workers in terms of both economic sectors and wages are addressed in Chapter 4 . 


\section{REFERENCES}

Anas, A., R. Arnott, and K. A. Small. 1998. Urban spatial structure. Journal of Economic Literature 36(3): 1426-1464.

Belzer, Dena, Sujata Srivastava, and Mason Austin. 2011. Transit and Regional Economic Development. Oakland, CA: Center for Transit-Oriented Development.

Boarnet, Marlon. 1997. Highways and economic productivity: Interpreting recent evidence. Journal of Planning Literature 11(4): 476-486.

Boarnet, Marlon G. and Andrew F. Haughwout. (2000). Do Highways Matter? Evidence and Policy Implications of Highways Influence on Metropolitan Development. Washington, DC: The Brookings Institution, Center on Urban and Metropolitan Policy.

Bogart, William T. (1998). The Economics of Cities and Suburbs. Upper Saddle River, NJ: Prentice Hall.

Calthorpe, Peter (1993). The Next American metropolis: Ecology, community, and the American Dream”. Princeton Architectural Press; 1993.

Carnegie Mellon Center for Economic Development. Undated. Methods of regional analysis: Shift-share. Pittsburgh, PA: H. John Heinz School of Public Policy and Management, Carnegie Mellon University. Accessed from http://www.andrew.cmu.edu/user/jp87/URED/readings/Shift_Share.pdf.

Cervero, Robert et al. (2004). TCRP Report 102: Transit-Oriented Development in the United States: Experiences, Challenges, and Prospects. Washington, DC: Transportation Research Board.

Chatman, Daniel G. and Robert B. Noland (2011). Do public transport improvements increase agglomeration economies? A review of literature and an agenda for research. Transport Reviews 31(6): 725-742.

Ciccone, Antonio, and Robert E. Hall. 1996. Productivity and the density of economic activity. American Economic Review 86: 54-70.

Galster, George C. (2012). The Mechanism(s) of Neighbourhood Effects: Theory, Evidence, and Policy Implications, Pp. 23-56 in van Ham, M., Manley, D., Bailey, N., Simpson, L., and Maclennan, D., eds. Neighbourhood Effects Research: New Perspectives. Dordrecht, NL: Springer, 2012.

Ganning, Joanna P. and Benjamin D. McCall. (2012). The Spatial Heterogeneity and Geographic Extent of Population Deconcentration: Measurement and Policy Implications. In International Handbook of Rural Demography, edited by Laszlo J. Kulcsar and Katherine J. Curtis, 319-332: Springer.

Glaeser, Edward. 2011. Triumph of the City How Our Greatest Invention Makes Us Richer, Smarter, Greener, Healthier, and Happier. New York: Penguin Books.

Graham, D. J. 2007. Agglomeration, productivity and transport investment. Journal of Transport Economics and Policy 41(3), September: 317-343. 
www.ingentaconnect.com/content/lse/jtep/2007/00000041/00000003/art00003. Summarized in OECD/ITF Discussion Paper 2007-11, www.internationaltransportforum.org/jtrc/DiscussionPapers/DiscussionPaper11.pdf.

Hinners, S. J., Nelson, A. C., \& Buchert, M. (2018). Streetcars and Economic Development: Do Streetcars Stimulate Employment Growth? Transportation Research Record. https://doi.org/10.1177/0361198118790096

Holmes, Thomas. 1999. How industries migrate when agglomeration economies are important. Journal of Urban Economics 45: 240-263.

Littman, T. 2009. Evaluating Transportation Economic Development Impacts. Victoria, BC: Victoria Transportation Institute, http://www.vtpi.org/econ_dev.pdf.

Nelson, A. C., G. Anderson, R. Ewing, P. Perlich, T. W. Sanchez, and K. Bartholomew. 2009. The Best Stimulus for the Money: Briefing Papers on the Economics of Transportation Spending. Salt Lake City: Metropolitan Research Center at the University of Utah for Smart Growth America. http://www.smartgrowthamerica.org/documents/thebeststimulus.pdf.

Nelson, Arthur C., Bruce Appleyard, Shyam Kannan, Reid Ewing, Matt Miller, Dejan Eskic (2013). Bus Rapid Transit and Economic Development: Case Study of the Eugene-Springfield BRT System. Journal of Public Transportation 16(3): 41-57.

Nelson, Arthur C., Dejan Eskic, Shima Hamidi, Reid Ewing, Susan J. Petheram and Jenny H. Liu (2015). Office Rent Premiums with Respect to Light Rail Transit Stations: Case Study of Dallas with Implications for TOD Planning. Transportation Research Record.

Nelson, A. C., Stoker, P., \& Hibberd, R. 2018. Light rail transit and economic recovery: A case of resilience or transformation? Research in Transportation Economics.

https://doi.org/10.1016/j.retrec.2018.11.003

Spectorsky, A. C. (1955). The Exurbanites. Philadelphia: Lippincott.

Renkow, M. and D.M. Hoover (2000). Commuting, migration, and the nonmetropolitan turnaround. Journal of Regional Science 40: 261-287.

Voith, Richard. (1998). Parking, Transit, and Employment in a Central Business District, Journal of Urban Economics 44(1): 43-48. 


\subsection{THE LINK BETWEEN TRANSIT STATION PROXIMITY AND CHANGE IN WORKERS BY ECONOMIC GROUPS AND WAGES SINCE THE GREAT RECESSION}

\subsection{OVERVIEW}

This chapter explores the distribution of the change of workers by economic groups since the Great Recession, 2011-2015. It then explores changes in the distribution of upper-, middle- and lower-wage workers during the same period. Firms with workers in the knowledge, office, and arts-entertainment-recreation economic groups are attracted to locations near transit stations. Firms with workers in the manufacturing and light manufacturing economic groups tend to locate some distance away from transit stations perhaps because of their need for large parcels of land built at low intensities. Firms in the retail-lodging-food service, education and health care economic groups appear to be trending toward locations near transit stations. We also find that between 2011 and 2015, workers in upper-wage economic groups dominated the change in worker wages near transit stations followed by workers in lower wage economic groups. Firms with middle-wage workers are being displaced from locations near transit stations. Implications for transit and land use planning are offered.

\subsection{INTRODUCTION AND LITERATURE REVIEW}

Transit systems expand accessibility options throughout metropolitan areas. As such, theory poses that transit station have advantages over other locations that can lead to firms clustering near them (Glaeser 2011). Over time, these transit station areas should generate economies of agglomeration among certain economic sectors that attract certain firms and their workers to them. At the time research began leading to this chapter, however, there were only four studies assessing worker change near transit stations. The first, Belzer et al. (2011), measured only the change in workers in firms by economic sector from 2002 to 2008 within one-half mile of transit stations. In the second, Nelson et al. (2011) evaluated the change in share of workers by sector within one-eighth mile and one-quarter mile of Eugene-Springfield BRT stations between 2004 and 2010. The third and fourth studies (Nelson et al. 2015, Nelson 2016) evaluated several light rail transit (LRT), bus rapid transit (BRT), streetcar transit (SCT), and commuter rail transit (CRT) systems in one-quarter mile distance band increments from transit stations to track shifts in the share of workers by economic group before and during the recession. A key finding for LRT systems is that while station areas lost regional share of workers before the Great Recession (2004 through 2007), they gained share during it (Nelson, Stoker and Hibberd 2018), though results for other modes were mixed (see Nelson et al. 2015, Nelson 2016). No studies have assessed the extent to which economic groups are attracted to, or repelled by, transit station proximity since the Great Recession. 
There is a second aspect to the kinds of workers that are attracted to transit stations: the relationship between transit station proximity by mode and workers' wages. Scholars and civil rights organizations assert that America's transportation policies perpetuate social and economic inequity. Sanchez and Brenman (2008), for instance, show that highway-based transportation investments limit the access of low-income and people-of-color to education, workers and services. Echoing their concern is the Leadership Conference Education Fund (Leadership Conference Education Fund, 2011a, 2011b), a civil rights organization which asserts that lowwage workers are inaccessible to those who are transit-dependent. Public transit is seen as one way to connect people to low-wage workers, reduce poverty, increase employment and help achieve social equity goals (Blumenberg et al. 2002; Blumenberg and Manville, 2004; Sen et al. 1999). Does transit — and in particular transit station proximity — deliver on this promise?

Fan et al. (2012) provide an especially pertinent review of literature addressing our question. Citing Kain's (1968; 1992) pioneering work, they observe that the urban poor are harmed for want of affordable housing near worker opportunities and reliable public transit to connect them to those workers (see also Blumenberg et al., 2002; Sanchez, 2008).

A limiting factor in gaining access to lower-wage workers is that the income from such workers is often insufficient to buy and operate an automobile to access those workers in the first place. Sanchez (1999) and Sanchez et al. (2004) note that it is difficult for public transit to reduce the spatial mismatch between lower-income workers and residential options for a number of reasons. One problem is that bus systems often do not provide sufficient service for the kinds of working hours that make low-skill/entry-level, temporary, and evening/weekend shift-work workers feasible (Giuliano, 2005). Fixed-route transit systems - if they are more rapid and reliable than conventional buses-may be one way to connect lower-income workers from their lower-income neighborhoods to lower-wage workers (Fan et al. 2012).

Unfortunately, there are very few empirical studies showing whether and the extent to which fixed-route transit systems produce these outcomes. It seems that just as many studies report positive outcomes (Ong and Houston, 2002; Ong and Miller, 2005; Kawabata, 2002; 2003) as negative ones or those with ambiguous associations (Thakuriah and Metaxatos, 2000; Cervero et al. 2002; Bania et al., 2008).

Two recent studies have further shown different results. In the first, McKenzie (2013) studies neighborhoods in Portland, OR, to identify differences in transit access for those neighborhoods. Using 2000 Census and five-year (2005-2009 American Community Survey) data, McKenzie compares changes in levels of transit access across neighborhoods based on their concentrations of blacks, Latinos and poor households. The study found that neighborhoods with a high Latino concentration have the poorest relative access to transit, and that transit access declined for black and Latino-dominated neighborhoods. McKenzie did not evaluate worker growth along transit lines serving or near those neighborhoods, however.

The other is the study by Fan et al. (2012). They find that residential proximity to light rail stations and bus stops offering direct connection to rail stations are associated with statistically significant gains in accessibility to low-wage workers. On the other hand, their analysis covered only a short period of time before the Great Recession: 2004 to 2007 but not since. The Center for Transportation Research at the University of Minnesota (Fan, et al., 2012) goes further by 
reporting that between 2004, when the Hiawatha Line LRT line opened, and 2007, just before the Great Recession, low-wage workers accessible within 30 minutes of transit within Hennepin County grew by 14,000, with another 4,000 where the LRT was accessed directly by bus.

In sum, there are no studies showing the relationship between fixed-route transit systems and wages differentiated by lower, middle and upper categories.

This chapter thus helps to close two gaps in the literature: whether there is link between transit station proximity and the change in workers by economic group, and the change in workers by wage group.

\subsubsection{Research Questions and Design}

We have two research questions:

Is there a link between transit station proximity and change in workers by economic group since the Great Recession?

And

Is there a link between transit station proximity and change in workers by wage group since the Great Recession?

Both questions lend themselves to post-hoc quasi-experimental design, notably change in conditions from the end of the Great Recession-we use 20118 to the most recent year for which data are available to address the questions_-in our case 2015.

\section{Transit Station Proximity and Change in Workers by Economic Group}

The Longitudinal Employment-Household Dynamics (LEHD) database provides information we need to address the research question. 9 This database provides information to the census block level for workers in all 20 of the North American Industrial Classification System's (NAICS) 2digit economic sectors. Like Belzer et al. (2011), we exclude natural resource-based sectors (reporting workers in agriculture, forestry, fishing and mining). The reason is that for the most part, they do not occupy structures. We also exclude workers in the construction sector since they do not occupy structures permanently. Like Belzer et al. (2011), we group the remaining economic sectors into eight economic groups roughly reflecting comparable land use needs. Office location and design for instance is different from education, manufacturing and other economic groups. The economic groups used in our analysis are shown in Table 4.1.

8 Although the Federal Reserve Board notes the Great Recession extended technically from the fourth quarter of 2007 through the second quarter of 2009, unemployment remained above 9.0\% through 2010 (see https://fred.stlouisfed.org/series/UNRATE/) and home values, a measure of economic recovery, did not begin to rebound until 2011 (see https://fred.stlouisfed.org/series/MSPUS). 9 For details, see https://lehd.ces.census.gov/. 
For each FRT mode (LRT, BRT, SCT and CRT), we assemble data on workers by economic group within one-eighth (0.125) mile distance bands from transit stations for 2011 and 2015. Although we collected these data for all FRT systems used in our analysis (see Table 4.2), we report overall results below.

We use two techniques for analysis. The first is descriptive statistics to compare changes between 2011 and 2015. We use z-scores $(p<0.01)$ to assure there exists a significant difference between these years. The second is locations quotients (LQs) to estimate the relative change in concentration of workers within each economic group over time. Changes in LQs can signal whether transit station proximity is attracting more firms and workers in a given economic group over time compared to other economic groups.

\section{Transit Station Proximity and Change in Workers by Wage Group}

The second question is addressed by aggregating the economic groups into larger groups reflecting median wages that we call upper wage, middle wage, and lower wage, as shown in Table 4.3. Changes in workers by wage group are calculated.

Table 4.1: Combinations of NAICS Sectors into Economic Groups for Analysis

\begin{tabular}{|c|c|}
\hline NAICS Code & NAICS Sector Title and Economic Group Name \\
\hline & Industrial \\
\hline $31-33$ & Manufacturing \\
\hline \multirow[t]{2}{*}{22} & Utilities \\
\hline & Light Industrial \\
\hline 42 & Wholesale Trade \\
\hline \multirow[t]{2}{*}{ 48-49 } & Transportation and Warehousing \\
\hline & Retail-Lodging-Food (“Retail-Lodging”) \\
\hline $44-45$ & Retail Trade \\
\hline \multirow[t]{2}{*}{72} & Accommodation and Food Services \\
\hline & Knowledge \\
\hline 51 & Information \\
\hline \multirow[t]{2}{*}{54} & Professional, Scientific, and Technical Services \\
\hline & Office \\
\hline 52 & Finance and Insurance \\
\hline 53 & Real Estate and Rental and Leasing \\
\hline 55 & Management of Companies and Enterprises \\
\hline 56 & Administrative and Support, Waste Management, Remediation \\
\hline 81 & Other Services (except Public Administration) \\
\hline \multirow[t]{2}{*}{92} & Public Administration \\
\hline & Education \\
\hline \multirow[t]{2}{*}{61} & Educational Services \\
\hline & Health \\
\hline \multirow[t]{2}{*}{62} & Health Care and Social Assistance \\
\hline & Arts-Entertainment-Recreation (“Arts-Ent-Rec”) \\
\hline 71 & Arts, Entertainment, and Recreation \\
\hline
\end{tabular}

Source: Adapted from the North American Industrial Classification System by Arthur C. Nelson and Robert Hibberd, University of Arizona.

Note: Phrases in quotations and italics labels for the respective economic groups. 
Table 4.2: Fixed Route Transit Systems Used in Study

\begin{tabular}{|c|c|c|c|c|c|c|c|}
\hline $\begin{array}{l}\text { Light Rail } \\
\text { Transit }\end{array}$ & Year & $\begin{array}{l}\text { Bus Rapid } \\
\text { Transit }\end{array}$ & Year & $\begin{array}{l}\text { Streetcar } \\
\text { Transit }\end{array}$ & Year & $\begin{array}{l}\text { Commuter Rail } \\
\text { Transit }\end{array}$ & Year \\
\hline Buffalo & 1984 & Cleveland & 2008 & Atlanta & 2014 & Albuquerque & 2006 \\
\hline Charlotte & 2007 & Eugene-Spring & 2007 & Dallas & 2015 & Austin & 2010 \\
\hline Cleveland & 1980 & Kansas City & 2005 & Little Rock & 2004 & Dallas-Fort Worth & 1996 \\
\hline Dallas & 1996 & Las Vegas & 2004 & Portland & 2001 & Miami Tri-Rail & 1989 \\
\hline Dallas & 1996 & Nashville & 2009 & Salt Lake City & 2013 & Minneapolis & 1997 \\
\hline Denver & 1994 & Phoenix & 2009 & Seattle & 2007 & Nashville & 2006 \\
\hline Denver & 1994 & Pittsburgh & 1977 & Tacoma & 2003 & Orlando & 2014 \\
\hline Houston & 2004 & Reno & 2010 & Tampa & 2002 & Portland & 2009 \\
\hline Minn.-St. Paul & 2004 & Salt Lake City & 2008 & Tucson & 2014 & Salt Lake City & 2008 \\
\hline Norfolk & 2011 & San Antonio & 2012 & & & San Diego & 1995 \\
\hline Phoenix & 2008 & San Diego & 2014 & & & San Jose-Stockton & 1998 \\
\hline Pittsburgh & 1984 & Seattle & 2010 & & & Seattle-Tacoma & 2000 \\
\hline Portland & 1986 & Stockton & 2007 & & & & \\
\hline Sacramento & 1987 & & & & & & \\
\hline Salt Lake City & 1999 & & & & & & \\
\hline Salt Lake City & 1999 & & & & & & \\
\hline San Diego & 1981 & & & & & & \\
\hline San Jose & 1987 & & & & & & \\
\hline Seattle & 2003 & & & & & & \\
\hline St. Louis & 1993 & & & & & & \\
\hline
\end{tabular}

Note: “Minn-St. Paul” means Minneapolis-St. Paul and "Eugene-Spring” means EugeneSpringfield. 
Table 4.3: Allocation of Workers by Lower-, Middle- and Upper-Wage Category

\begin{tabular}{|c|c|c|c|c|}
\hline NAICS & Description & $\begin{array}{c}\text { Mean Annual } \\
\text { Wages, } 2013\end{array}$ & $\begin{array}{c}\text { Wage } \\
\text { Category }\end{array}$ & $\begin{array}{l}\text { Share of } \\
\text { Workers }\end{array}$ \\
\hline 44 & Retail Trade & $\$ 25,779$ & Lower & \\
\hline 56 & Administrative, Support, Waste Mgmt., Remediation & $\$ 35,931$ & Lower & \\
\hline 61 & Educational Services & $\$ 35,427$ & Lower & \\
\hline 71 & Arts, Entertainment and Recreation & $\$ 32,188$ & Lower & \\
\hline 72 & Accommodation and Food Services & $\$ 17,453$ & Lower & \\
\hline \multirow[t]{2}{*}{81} & Other Services (except Public Administration) & $\$ 29,021$ & Lower & \\
\hline & \multicolumn{2}{|l|}{ Weighted Mean Wages and National Share of Workers } & $\sim \$ 30,000$ & $\sim 33 \%$ \\
\hline 48 & Transportation and Warehousing & $\$ 45,171$ & Middle & \\
\hline 53 & Real Estate and Rental and Leasing & $\$ 46,813$ & Middle & \\
\hline 62 & Health Care and Social Assistance & $\$ 44,751$ & Middle & \\
\hline \multirow[t]{2}{*}{92} & Public Administration & $\$ 51,340$ & Middle & \\
\hline & \multicolumn{2}{|l|}{ Weighted Mean Wages and National Share of Workers } & $\sim \$ 50,000$ & $\sim 33 \%$ \\
\hline 22 & Utilities & $\$ 94,239$ & Upper & \\
\hline 31 & Manufacturing & $\$ 54,258$ & Upper & \\
\hline 42 & Wholesale Trade & $\$ 65,385$ & Upper & \\
\hline 51 & Information & $\$ 83,677$ & Upper & \\
\hline 52 & Finance and Insurance & $\$ 88,677$ & Upper & \\
\hline 54 & Professional, Scientific and Technical Services & $\$ 75,890$ & Upper & \\
\hline \multirow[t]{2}{*}{55} & Management of Companies and Enterprises & $\$ 105,138$ & Upper & \\
\hline & \multicolumn{2}{|l|}{ Weighted Mean Wages and National Share of Workers } & $\sim \$ 70,000$ & $34 \%$ \\
\hline
\end{tabular}

Source: Adapted from County Business Patterns, 2013 by Arthur C. Nelson and Robert Hibberd, University of Arizona. 


\subsection{FINDINGS}

We report findings separately for economic groups and then wage groups. This is followed by overall implications for transit and land use planning.

\subsubsection{Economic Group Findings}

Even-numbered Tables 4.4 through 4.10 report changes in workers by economic group and oneeighth (0.125) mile distance band to one (1.0) mile from LRT, BRT, SCT, and CRT stations respectively. These tables report numerical changes, percentage changes, and share of change with respect to the Transit Region that is comprised of all counties within which a type of FRT system operates. Figures highlighted in bold are those with positive results in either the first (0.125-mile) or second (0.25-mile) distance bands to the one-half (0.50) mile distance band. Odd-numbered tables 4.5 through 4.11 report location quotients for 2015-highlighting those economic groups that tend to concentrate near transit stations (highlighted) — and the ratio of 2015 to 2011 LQs noting that where the ratio is greater than 1.0 for certain economic groups, those groups may be increasing their preference for locating near transit stations. Later, in our implications section, we note that unless local efforts are made to improve accessibility between the outer distance bands and transit stations (we pose some ideas), we assume that transit and land use planners should focus on actions that facilitate growth among economic groups that are shown in our analysis to be attracted to locations near transit stations. We summarize findings for each type of FRT system.

\subsubsection{Light Rail Transit Systems}

Table 4.4 indicates that LRT station areas are gaining workers in various distance bands among the Retail-Lodge, Knowledge. Office, Health and Arts-Ent-Rec economic groups. We are surprised to find, however, that overall worker growth is modest (see upper part of Table 4.4) and represent small shares of total Transit Region employment growthindeed being smaller than those associate with other FRT systems as will be shown. Combining insights of Chapters 2 and 8, the reason may be that LRT station location, planning and design does not maximize market and economic development responsiveness to LRT station proximity.

The lower part of Table 4.5 may be used to identify targets of economic development opportunities among economic groups based on the growth concentration of workers over the period 2011 through 2015. Notably, economic development opportunities within onehalf (0.50) mile of LRT stations may exist among these economic groups:

- Retail-Lodging-Food Service

- Knowledge

- Office

- Education 
- Health

- Arts-Entertainment-Recreation

This is not to say that all firms within these economic groups may be attracted to LRT stations or that firms in other economic groups will not be. For instance, micro-breweries are classified as a manufacturing activity by the NAICS yet they are expanding especially in downtowns and other centers near transit stations. 
Table 4.4: Change in Workers by Economic Group and Distance Band from LRT Station, 2011-2015

\begin{tabular}{|c|c|c|c|c|c|c|c|c|}
\hline Distance Band & 0.125 & 0.25 & 0.375 & 0.50 & 0.625 & 0.75 & 0.875 & 1.00 \\
\hline $\begin{array}{l}\text { Economic } \\
\text { Group } \\
\end{array}$ & \multicolumn{8}{|c|}{ Worker Change 2011-2015 } \\
\hline Manufacturing & $(3,122)$ & $(8,509)$ & 2,104 & 571 & (9) & 1,916 & 1,608 & $(2,887)$ \\
\hline $\begin{array}{l}\text { Light } \\
\text { Industrial }\end{array}$ & $(8,332)$ & $(5,377)$ & 1,934 & $(2,349)$ & 4,275 & 2,104 & 2,249 & 10,501 \\
\hline $\begin{array}{c}\text { Retail- } \\
\text { Lodging }\end{array}$ & 18,572 & 13,005 & 10,462 & 24,094 & 11,117 & 7,733 & 6,221 & 10,501 \\
\hline Knowledge & 40,862 & $(2,680)$ & 11,311 & 10,085 & 6,714 & 5,114 & 9,577 & 4,916 \\
\hline Office & $(40,240)$ & 16,567 & 1,757 & 24,047 & 10,487 & 709 & 7,687 & $(9,684)$ \\
\hline Education & $(3,032)$ & $(12,852)$ & 2,186 & $(16,838)$ & 12,562 & $(2,739)$ & $\begin{array}{l}(109) \\
\end{array}$ & $(5,356)$ \\
\hline Health & 24,305 & 6,559 & 15,309 & 2,191 & 5,795 & 18,390 & $(3,086)$ & 5,782 \\
\hline Arts-Ent-Rec & 749 & 2,766 & 1,644 & 1,333 & 2,175 & 762 & 550 & 1,398 \\
\hline Total & 29,762 & 9,479 & 46,707 & 43,134 & 53,116 & 33,989 & 24,697 & 15,171 \\
\hline $\begin{array}{l}\text { Economic } \\
\text { Group }\end{array}$ & \multicolumn{8}{|c|}{ Percent Worker Change 2011-2015 } \\
\hline Manufacturing & $-4 \%$ & $-11 \%$ & $7 \%$ & $2 \%$ & $-0 \%$ & $8 \%$ & $6 \%$ & $-9 \%$ \\
\hline $\begin{array}{l}\text { Light } \\
\text { Industrial }\end{array}$ & $-7 \%$ & $-4 \%$ & $3 \%$ & $-6 \%$ & $16 \%$ & $5 \%$ & $10 \%$ & $23 \%$ \\
\hline $\begin{array}{l}\text { Retail- } \\
\text { Lodging }\end{array}$ & $10 \%$ & $7 \%$ & $13 \%$ & $32 \%$ & $17 \%$ & $14 \%$ & $12 \%$ & $23 \%$ \\
\hline Knowledge & $18 \%$ & $-1 \%$ & $21 \%$ & $23 \%$ & $16 \%$ & $11 \%$ & $35 \%$ & $16 \%$ \\
\hline Office & $-6 \%$ & $3 \%$ & $1 \%$ & $17 \%$ & $12 \%$ & $1 \%$ & $11 \%$ & $-13 \%$ \\
\hline Education & $-3 \%$ & $-13 \%$ & $6 \%$ & $-39 \%$ & $24 \%$ & $-4 \%$ & $-0 \%$ & $-14 \%$ \\
\hline Health & $16 \%$ & $4 \%$ & $14 \%$ & $2 \%$ & $8 \%$ & $31 \%$ & $-5 \%$ & $16 \%$ \\
\hline Arts-Ent-Rec & $2 \%$ & $7 \%$ & $17 \%$ & $17 \%$ & $39 \%$ & $8 \%$ & $15 \%$ & $50 \%$ \\
\hline Total & $2 \%$ & $1 \%$ & $9 \%$ & $9 \%$ & $14 \%$ & $9 \%$ & $8 \%$ & $5 \%$ \\
\hline $\begin{array}{l}\text { Economic } \\
\text { Group }\end{array}$ & \multicolumn{8}{|c|}{ Transit Region Share of Economic Group Worker Change 2011-2015 } \\
\hline Manufacturing & $-6 \%$ & $-15 \%$ & $4 \%$ & $1 \%$ & $-0 \%$ & $3 \%$ & $3 \%$ & $-5 \%$ \\
\hline $\begin{array}{l}\text { Light } \\
\text { Industrial }\end{array}$ & $-6 \%$ & $-4 \%$ & $1 \%$ & $-2 \%$ & $3 \%$ & $2 \%$ & $2 \%$ & $3 \%$ \\
\hline $\begin{array}{l}\text { Retail- } \\
\text { Lodging }\end{array}$ & $5 \%$ & $3 \%$ & $3 \%$ & $6 \%$ & $3 \%$ & $2 \%$ & $2 \%$ & $3 \%$ \\
\hline Knowledge & $16 \%$ & $-1 \%$ & $4 \%$ & $4 \%$ & $3 \%$ & $2 \%$ & $4 \%$ & $2 \%$ \\
\hline Office & $-15 \%$ & $6 \%$ & $1 \%$ & $9 \%$ & $4 \%$ & $0 \%$ & $3 \%$ & $-4 \%$ \\
\hline Education & $-10 \%$ & $-42 \%$ & $7 \%$ & $-55 \%$ & $41 \%$ & $-9 \%$ & $-0 \%$ & $-18 \%$ \\
\hline Health & $8 \%$ & $2 \%$ & $5 \%$ & $1 \%$ & $2 \%$ & $6 \%$ & $-1 \%$ & $2 \%$ \\
\hline Arts-Ent-Rec & $2 \%$ & $8 \%$ & $5 \%$ & $4 \%$ & $6 \%$ & $2 \%$ & $2 \%$ & $4 \%$ \\
\hline Total & $2 \%$ & $1 \%$ & $3 \%$ & $3 \%$ & $4 \%$ & $2 \%$ & $2 \%$ & $1 \%$ \\
\hline
\end{tabular}

Source: Arthur C. Nelson and Robert Hibberd, University of Arizona. 
Table 4.5: Location Quotients by Economic Group for 2015 and LQ Trends 2011-2015 by Economic Group by Distance Band from LRT Station

\begin{tabular}{|c|c|c|c|c|c|c|c|c|}
\hline & \multicolumn{8}{|c|}{ Location Quotients 2015} \\
\hline $\begin{array}{l}\text { Distance Band, } \\
\text { Economic Group }\end{array}$ & 0.125 & 0.25 & 0.375 & 0.5 & 0.625 & 0.75 & 0.875 & 1 \\
\hline Manufacturing & 0.56 & 0.62 & 0.69 & 0.75 & 0.77 & 0.75 & 1.1 & 1.23 \\
\hline Light Industrial & 0.73 & 0.6 & 1.15 & 0.67 & 0.72 & 1.03 & 0.81 & 0.95 \\
\hline Retail-Lodging & 0.67 & 0.8 & 0.8 & 0.97 & 0.87 & 0.73 & 0.89 & 0.95 \\
\hline Knowledge & 1.46 & 1.33 & 1 & 0.89 & 0.98 & 1.02 & 0.98 & 1.02 \\
\hline Office & 1.49 & 1.4 & 0.96 & 1.27 & 0.91 & 0.82 & 0.93 & 0.9 \\
\hline Education & 0.7 & 0.79 & 0.81 & 0.6 & 1.75 & 1.72 & 1.13 & 1.26 \\
\hline Health & 0.79 & 0.88 & 1.54 & 1.29 & 1.24 & 1.32 & 1.33 & 1.03 \\
\hline \multirow[t]{2}{*}{ Arts-Ent-Rec } & 1.35 & 1.33 & 1.09 & 0.97 & 0.98 & 1.38 & 0.69 & 0.78 \\
\hline & \multicolumn{8}{|c|}{ LQ Trend 2011-2015 [2015LQ / 2011LQ] } \\
\hline $\begin{array}{l}\text { Distance Band, } \\
\text { Economic Group }\end{array}$ & 0.125 & 0.25 & 0.375 & 0.5 & 0.625 & 0.75 & 0.875 & 1 \\
\hline Manufacturing & 0.99 & 0.87 & 1.03 & 0.98 & 0.92 & 1.04 & 1.03 & 0.92 \\
\hline Light Industrial & 0.92 & 0.9 & 0.95 & 0.86 & 1.03 & 0.97 & 1.02 & 1.14 \\
\hline Retail-Lodging & 1.04 & 1.06 & 1 & 1.17 & 1 & 1.02 & 1 & 1.14 \\
\hline Knowledge & 1.11 & 0.93 & 1.06 & 1.08 & 0.98 & 0.98 & 1.2 & 1.07 \\
\hline Office & 0.94 & 1.07 & 0.95 & 1.1 & 1.01 & 0.95 & 1.06 & 0.86 \\
\hline Education & 1.02 & 0.87 & 1.04 & 0.6 & 1.16 & 0.94 & 0.98 & 0.88 \\
\hline Health & 1.09 & 1.01 & 1 & 0.9 & 0.91 & 1.15 & 0.84 & 1.06 \\
\hline Arts-Ent-Rec & 0.98 & 1.12 & 1.05 & 1.05 & 1.2 & 0.97 & 1.05 & 1.41 \\
\hline
\end{tabular}

Source: Arthur C. Nelson and Robert Hibberd, University of Arizona.

Note: Cells with white bold figures against black backgrounds have LQs or 2015/2011 LQ rations equal to or greater than 1.0 indicating either that an economic group concentrates within one-half (0.50) mile of transit stations (upper part of the table) or trended toward greater concentration from 2011 to 2015. Cells with black bold figures against gray backgrounds indicate that an economic group's performance in one cell is adjacent to others where figures are greater than 1.0 and as such suggest potential spillovers from the cell with the higher figure into the lower one where the lower one is also substantially close to 1.0 in its own right. See text for interpretations. 


\subsubsection{Bus Rapid Transit Systems}

Compared to LRT systems, BRT systems appear to have more robust outcomes than those of LRT systems, as suggested in Tables 4.6 and 4.7. We explore reasons below though with some surprise.

Table 4.6 shows that BRT LRT station areas are gaining workers in several distance bands among the Manufacturing, Light Industrial, Retail-Lodging, Knowledge, Education, Health, and Arts-Ent-Rec economic groups-which all economic groups except for Office. We are impressed that overall worker growth is large but mostly limited to the first $(0.125$-mile) distance band at $11 \%$, and a much smaller share of growth in the next (0.25-mile) distance band at $2 \%$. This is nearly exactly what Nelson et al.-(2013) found in their case study of the Eugene-Springfield BRT system wherein more than $80 \%$ of worker gains occurred in the first 0.125 -mile distance band with nearly all the rest occurring in the next (0.25-mile) distance band. We are further impressed because in contrast, LRT systems absorbed $10 \%$ of all Transit Region worker growth across the half-mile ( 0.50$)$ distance from LRT stations, absorbing only $3 \%$ within the first quarter (0.25) mile distance.

This finding is further interesting because in Chapter 2 we found no market premiums with respect to office and retail (and multifamily) location within the first (0.125-mile) distance band. We pose reasons for this in Chapter 8. One wonders how much more economic development could occur through improvements in the planning, location, and design of BRT stations.

Trends shown in Table 4.7 suggest that all economic groups are potential targets for economic development with respect to BRT station proximity. To be consistent with our format elsewhere, these are the economic groups that may be targeted for locating near BRT stations:

- Manufacturing

- Light Industrial

- Retail-Lodging-Food Service

- Knowledge

- Office

- Education

- Health

- Arts-Entertainment-Recreation 
However, based on other research and findings in Table 4.6, the target area may be limited to especially the first (0.125-mile) and second (0.25-mile) distance bands. On the other hand, improvements to the planning, location, and design of BRT stations may (a) improve economic development opportunities in those bands and extend them outward to the next one (0.375-mile) or two (0.50-mile) distance bands. This is an area needing further research.

Table 4.6: Change in Workers by Economic Group and Distance Band from BRT Station, 2011-2015

\begin{tabular}{|c|c|c|c|c|c|c|c|c|}
\hline Distance Band & 0.125 & 0.25 & 0.375 & 0.50 & 0.625 & 0.75 & 0.875 & 1.00 \\
\hline Economic Group & \multicolumn{8}{|c|}{ Worker Change 2011-2015 } \\
\hline Manufacturing & 228 & 3,132 & $(3,085)$ & 1,201 & $(2,387)$ & (209) & 1,303 & $(800)$ \\
\hline $\begin{array}{l}\text { Light } \\
\text { Industrial }\end{array}$ & 6,639 & $(7,875)$ & 2,328 & 688 & 3,209 & 1,529 & 1,955 & 6,172 \\
\hline Retail-Lodging & 42,992 & 9,608 & 6,048 & 18,200 & 6,820 & 668 & 1,687 & 6,172 \\
\hline Knowledge & 24,000 & 6,384 & 5,263 & 9,134 & 1,728 & 3,071 & 2,545 & 2,833 \\
\hline Office & $(9,332)$ & $(1,054)$ & $(14,007)$ & 1,083 & $(976)$ & 905 & $(2,744)$ & $(1,512)$ \\
\hline Education & 2,088 & $(792)$ & 1,681 & $(108)$ & 7,494 & 2,896 & 859 & $(5,230)$ \\
\hline Health & 10,889 & 3,681 & 4,402 & 445 & 14,655 & 4,161 & 4,531 & $(613)$ \\
\hline Arts-Ent-Rec & 3,490 & 1,084 & 704 & 800 & 828 & $(618)$ & 104 & 121 \\
\hline Total & 80,994 & 14,168 & 3,334 & 31,443 & 31,371 & 12,403 & 10,240 & 7,143 \\
\hline Economic Group & \multicolumn{8}{|c|}{ Percent Worker Change 2011-2015 } \\
\hline Manufacturing & $1 \%$ & $8 \%$ & $-22 \%$ & $\mathbf{8 \%}$ & $-10 \%$ & $-2 \%$ & $11 \%$ & $-7 \%$ \\
\hline $\begin{array}{l}\text { Light } \\
\text { Industrial }\end{array}$ & $8 \%$ & $-9 \%$ & $9 \%$ & $3 \%$ & $16 \%$ & $10 \%$ & $15 \%$ & $18 \%$ \\
\hline Retail-Lodging & $11 \%$ & $2 \%$ & $10 \%$ & $31 \%$ & $19 \%$ & $2 \%$ & $6 \%$ & $18 \%$ \\
\hline Knowledge & $10 \%$ & $3 \%$ & $15 \%$ & $29 \%$ & $6 \%$ & $18 \%$ & $19 \%$ & $15 \%$ \\
\hline Office & $-2 \%$ & $-0 \%$ & $-15 \%$ & $2 \%$ & $-2 \%$ & $2 \%$ & $-7 \%$ & $-4 \%$ \\
\hline Education & $1 \%$ & $-1 \%$ & $6 \%$ & $-1 \%$ & $49 \%$ & $12 \%$ & $9 \%$ & $-20 \%$ \\
\hline Health & $6 \%$ & $2 \%$ & $8 \%$ & $1 \%$ & $30 \%$ & $14 \%$ & $16 \%$ & $-1 \%$ \\
\hline Arts-Ent-Rec & $11 \%$ & $3 \%$ & $12 \%$ & $18 \%$ & $20 \%$ & $-19 \%$ & $5 \%$ & $5 \%$ \\
\hline Total & $5 \%$ & $1 \%$ & $1 \%$ & $13 \%$ & $14 \%$ & $7 \%$ & $7 \%$ & $3 \%$ \\
\hline Economic Group & \multicolumn{8}{|c|}{ Transit Region Share of Economic Group Worker Change 2011-2015 } \\
\hline Manufacturing & $1 \%$ & $10 \%$ & $-10 \%$ & $4 \%$ & $-8 \%$ & $-1 \%$ & $4 \%$ & $-3 \%$ \\
\hline $\begin{array}{l}\text { Light } \\
\text { Industrial }\end{array}$ & $17 \%$ & $-20 \%$ & $6 \%$ & $2 \%$ & $8 \%$ & $4 \%$ & $5 \%$ & $3 \%$ \\
\hline Retail-Lodging & $18 \%$ & $4 \%$ & $2 \%$ & $7 \%$ & $3 \%$ & $0 \%$ & $1 \%$ & $3 \%$ \\
\hline Knowledge & $17 \%$ & $5 \%$ & $4 \%$ & $7 \%$ & $1 \%$ & $2 \%$ & $2 \%$ & $2 \%$ \\
\hline Office & $-12 \%$ & $-1 \%$ & $-18 \%$ & $1 \%$ & $-1 \%$ & $1 \%$ & $-4 \%$ & $-2 \%$ \\
\hline Education & $11 \%$ & $-4 \%$ & $9 \%$ & $-1 \%$ & $38 \%$ & $15 \%$ & $4 \%$ & $-27 \%$ \\
\hline Health & $7 \%$ & $2 \%$ & $3 \%$ & 0\% & $9 \%$ & $3 \%$ & $3 \%$ & $-0 \%$ \\
\hline Arts-Ent-Rec & $15 \%$ & $5 \%$ & $3 \%$ & $3 \%$ & $4 \%$ & $-3 \%$ & $0 \%$ & $1 \%$ \\
\hline Total & $11 \%$ & $2 \%$ & $0 \%$ & $4 \%$ & $4 \%$ & $2 \%$ & $1 \%$ & $1 \%$ \\
\hline
\end{tabular}

Source: Arthur C. Nelson and Robert Hibberd, University of Arizona. 
Table 4.7: Location Quotients by Economic Group for 2015 and LQ Trends 2011-2015 by Economic Group by Distance Band from BRT Station

\begin{tabular}{|c|c|c|c|c|c|c|c|c|}
\hline & \multicolumn{8}{|c|}{ Location Quotients 2015} \\
\hline $\begin{array}{l}\text { Distance } \\
\text { Band, } \\
\text { Economic } \\
\text { Group }\end{array}$ & 0.125 & 0.25 & 0.375 & 0.5 & 0.625 & 0.75 & 0.875 & 1 \\
\hline Manufacturing & 0.29 & 0.88 & 0.39 & 0.74 & 0.98 & 0.67 & 1.02 & 0.65 \\
\hline $\begin{array}{l}\text { Light } \\
\text { Industrial }\end{array}$ & 0.66 & 0.63 & 1.08 & 0.89 & 1.08 & 1 & 1.12 & 0.89 \\
\hline $\begin{array}{l}\text { Retail- } \\
\text { Lodging }\end{array}$ & 1.16 & 0.86 & 0.91 & 1.23 & 0.75 & 0.72 & 0.87 & 0.89 \\
\hline Knowledge & 1.29 & 1.41 & 1.1 & 1.25 & 1.03 & 0.89 & 0.86 & 0.93 \\
\hline Office & 1.19 & 1.18 & 1.03 & 0.78 & 0.75 & 1.09 & 0.96 & 0.79 \\
\hline Education & 1.09 & 0.85 & 1.1 & 0.83 & 1.06 & 1.66 & 0.78 & 1.21 \\
\hline Health & 0.78 & 0.91 & 1.28 & 1.12 & 1.73 & 1.25 & 1.48 & 1.91 \\
\hline \multirow[t]{2}{*}{ Arts-Ent-Rec } & 0.96 & 1.41 & 0.97 & 0.89 & 0.89 & 0.61 & 0.69 & 0.54 \\
\hline & \multicolumn{8}{|c|}{ LQ Trend 2011-2015 [2015LQ / 2011LQ] } \\
\hline $\begin{array}{l}\text { Distance } \\
\text { Band, } \\
\text { Economic } \\
\text { Group }\end{array}$ & 0.125 & 0.25 & 0.375 & 0.5 & 0.625 & 0.75 & 0.875 & 1 \\
\hline Manufacturing & 1 & 1.12 & 0.8 & 0.99 & 0.82 & 0.96 & 1.08 & 0.95 \\
\hline $\begin{array}{l}\text { Light } \\
\text { Industrial }\end{array}$ & 1.05 & 0.74 & 1.11 & 0.94 & 1.05 & 1.06 & 1.11 & 1.11 \\
\hline $\begin{array}{l}\text { Retail- } \\
\text { Lodging }\end{array}$ & 1.01 & 1.05 & 1.05 & 1.12 & 1 & 0.92 & 0.95 & 1.11 \\
\hline Knowledge & 1 & 1.01 & 1.08 & 1.09 & 0.88 & 1.05 & 1.06 & 1.06 \\
\hline Office & 0.98 & 1 & 0.88 & 0.95 & 0.9 & 1 & 0.91 & 0.98 \\
\hline Education & 1.02 & 1 & 1.11 & 0.93 & 1.38 & 1.11 & 1.08 & 0.83 \\
\hline Health & 0.97 & 0.99 & 1.02 & 0.85 & 1.09 & 1.02 & 1.04 & 0.92 \\
\hline Arts-Ent-Rec & 1.02 & 1.02 & 1.06 & 1 & 1.02 & 0.73 & 0.94 & 0.99 \\
\hline
\end{tabular}

Source: Arthur C. Nelson and Robert Hibberd, University of Arizona.

Note: Cells with white bold figures against black backgrounds have LQs or 2015/2011 LQ rations equal to or greater than 1.0 indicating either that an economic group concentrates within one-half (0.50) mile of transit stations (upper part of the table) or trended toward greater concentration from 2011 to 2015. Cells with black bold figures against gray backgrounds indicate that an economic group's performance in one cell is adjacent to others where figures are greater than 1.0 and as such suggest potential spillovers from the cell with the higher figure into 
the lower one where the lower one is also substantially close to 1.0 in its own right. See text for interpretations.

\subsubsection{Streetcar Transit Systems}

Along with BRT systems, SCT systems have emerged recently among many metropolitan areas. They are also associated with absorbing the second largest share of Transit Region employment growth between 2011 and 2015.

In Table 4.8, we see that SCT systems enjoyed employment growth in nearly all economic groups in the first (0.125-mile) distance band-the exception being Health. While Office employment is negative over the next distance bands to 0.50 -mile, they remain positive for the Retail-Lodging, Knowledge, and Arts-Ent-Rec economic groups_-and Health gains as well.

Overall, SCT systems accounted for 9\% of their Transit Region employment growth in the first (0.125-mile) distance band. Indeed, over the next three distance bands to 0.50 mile, SCT systems do not account for any of their Transit Regions' employment growth.

While Table 4.9 shows strong employment concentrations in the Knowledge, Office, Education and Arts-Ent-Rec economic groups, others are notable for their lack of concentration. Yet, the bottom part of this table shows that all but the Manufacturing economic group are trending toward concentration in among nearly all distance bands. From an economic development perspective, these may be target economic groups through the first three distance bands (to 0.375-mile):

- $\quad$ Light Industrial

- Retail-Lodging-Food Service

- Knowledge

- Office

- Education

- Health

- Arts-Entertainment-Recreation 
Table 4.8: Change in Workers by Economic Group and Distance Band from SCT Station, 2011-2015

\begin{tabular}{|c|c|c|c|c|c|c|c|c|}
\hline SCT Systems & 0.125 & 0.25 & 0.375 & 0.50 & 0.625 & 0.75 & 0.875 & 1.00 \\
\hline Economic Group & \multicolumn{8}{|c|}{ Worker Change 2011-2015 } \\
\hline Manufacturing & 93 & $(2,196)$ & 554 & $(438)$ & 1,387 & 71 & 110 & 2,715 \\
\hline $\begin{array}{l}\text { Light } \\
\text { Industrial }\end{array}$ & 6,256 & $\overline{(2,338)}$ & 788 & $(243)$ & 271 & 1,903 & 910 & 1,079 \\
\hline Retail-Lodging & 10,095 & 6,589 & 15,123 & 1,921 & 421 & 2,418 & 1,284 & 1,079 \\
\hline Knowledge & 21,716 & 486 & 6,863 & 234 & 243 & $(1,107)$ & 956 & 517 \\
\hline Office & 20,153 & $(11,756)$ & $(29,507)$ & $(260)$ & 1,132 & 13,251 & 2,243 & $(11,498)$ \\
\hline Education & 2,413 & 1,081 & $(6,020)$ & 10,593 & $(14,211)$ & $(100)$ & (333) & $(1,387)$ \\
\hline Health & $(2,363)$ & 1,936 & 6,454 & 1,761 & $(1,005)$ & 1,442 & $(978)$ & 206 \\
\hline Arts-Ent-Rec & 4,084 & 779 & 602 & 410 & 380 & 183 & 288 & 202 \\
\hline Total & 62,447 & $(5,419)$ & $(5,143)$ & 13,978 & $(11,382)$ & 18,061 & 4,480 & $(7,087)$ \\
\hline Economic Group & \multicolumn{8}{|c|}{ Percent Worker Change 2011-2015 } \\
\hline Manufacturing & $2 \%$ & $-41 \%$ & $11 \%$ & $-11 \%$ & $22 \%$ & $3 \%$ & $3 \%$ & $81 \%$ \\
\hline $\begin{array}{l}\text { Light } \\
\text { Industrial }\end{array}$ & $38 \%$ & $-14 \%$ & $7 \%$ & $-2 \%$ & $4 \%$ & $36 \%$ & $15 \%$ & $17 \%$ \\
\hline Retail-Lodging & $13 \%$ & $9 \%$ & $57 \%$ & $14 \%$ & $4 \%$ & $31 \%$ & $13 \%$ & $17 \%$ \\
\hline Knowledge & $27 \%$ & $1 \%$ & $25 \%$ & $1 \%$ & $3 \%$ & $-11 \%$ & $19 \%$ & $6 \%$ \\
\hline Office & $14 \%$ & $-8 \%$ & $-29 \%$ & $-1 \%$ & $7 \%$ & $85 \%$ & $19 \%$ & $-49 \%$ \\
\hline Education & $6 \%$ & $3 \%$ & $-16 \%$ & $122 \%$ & $-55 \%$ & $-7 \%$ & $-4 \%$ & $-13 \%$ \\
\hline Health & $-4 \%$ & $3 \%$ & $21 \%$ & $9 \%$ & $-6 \%$ & $20 \%$ & $-18 \%$ & $3 \%$ \\
\hline Arts-Ent-Rec & $34 \%$ & $6 \%$ & $17 \%$ & $13 \%$ & $25 \%$ & $7 \%$ & $76 \%$ & $12 \%$ \\
\hline Total & $14 \%$ & $-1 \%$ & $-2 \%$ & $11 \%$ & $-13 \%$ & $35 \%$ & $9 \%$ & $-10 \%$ \\
\hline Economic Group & \multicolumn{8}{|c|}{ Transit Region Share of Economic Group Worker Change 2011-2015 } \\
\hline Manufacturing & $-8 \%$ & $178 \%$ & $-45 \%$ & $35 \%$ & $-112 \%$ & $-6 \%$ & $-9 \%$ & $-220 \%$ \\
\hline $\begin{array}{l}\text { Light } \\
\text { Industrial }\end{array}$ & $7 \%$ & $-3 \%$ & $1 \%$ & $-0 \%$ & $0 \%$ & $2 \%$ & $1 \%$ & $1 \%$ \\
\hline Retail-Lodging & $5 \%$ & $3 \%$ & $8 \%$ & $1 \%$ & $0 \%$ & $1 \%$ & $1 \%$ & $1 \%$ \\
\hline Knowledge & $19 \%$ & 0\% & $6 \%$ & 0\% & $0 \%$ & $-1 \%$ & $1 \%$ & $0 \%$ \\
\hline Office & $17 \%$ & $-10 \%$ & $-25 \%$ & $-0 \%$ & $1 \%$ & $11 \%$ & $2 \%$ & $-10 \%$ \\
\hline Education & $6 \%$ & $3 \%$ & $-15 \%$ & $27 \%$ & $-37 \%$ & $-0 \%$ & $-1 \%$ & $-4 \%$ \\
\hline Health & $-2 \%$ & $2 \%$ & $7 \%$ & $2 \%$ & $-1 \%$ & $1 \%$ & $-1 \%$ & $0 \%$ \\
\hline Arts-Ent-Rec & $28 \%$ & $5 \%$ & $4 \%$ & $3 \%$ & $3 \%$ & $1 \%$ & $2 \%$ & $1 \%$ \\
\hline Total & $9 \%$ & $-1 \%$ & $-1 \%$ & $2 \%$ & $-2 \%$ & $3 \%$ & $1 \%$ & $-1 \%$ \\
\hline
\end{tabular}

Source: Arthur C. Nelson and Robert Hibberd, University of Arizona. 
Table 4.9: Location Quotients by Economic Group for 2015 and LQ Trends 2011-2015 by Economic Group by Distance Band from SCT Station

\begin{tabular}{|c|c|c|c|c|c|c|c|c|}
\hline \multirow{2}{*}{$\begin{array}{l}\text { SCT Systems } \\
\text { Distance } \\
\text { Band, } \\
\text { Economic } \\
\text { Group }\end{array}$} & \multicolumn{8}{|c|}{ Location Quotients 2015} \\
\hline & 0.125 & 0.25 & 0.375 & 0.5 & 0.625 & 0.75 & 0.875 & 1 \\
\hline Manufacturing & 0.16 & 0.31 & 0.34 & 0.41 & 1.49 & 0.5 & 0.99 & 1.6 \\
\hline $\begin{array}{l}\text { Light } \\
\text { Industrial }\end{array}$ & 0.43 & 0.57 & 0.48 & 0.72 & 0.78 & 0.95 & 1.19 & 0.67 \\
\hline Retail-Lodge & 0.87 & 0.74 & 0.88 & 0.59 & 0.65 & 0.73 & 1.03 & 0.67 \\
\hline Knowledge & 1.58 & 1.57 & 1.12 & 1.37 & 0.86 & 0.99 & 0.84 & 1.34 \\
\hline Office & 1.3 & 1.5 & 1.17 & 1.04 & 0.84 & 1.59 & 0.99 & 0.83 \\
\hline Education & 1.07 & 0.79 & 1.63 & 1.73 & 1.8 & 0.22 & 1.72 & 2.08 \\
\hline Health & 0.79 & 0.67 & 1.1 & 1.18 & 1.35 & 0.9 & 0.61 & 0.92 \\
\hline \multirow[t]{2}{*}{ Arts-Ent-Rec } & 1.72 & 1.19 & 0.91 & 1.41 & 1.29 & 2.05 & 0.65 & 1.78 \\
\hline & \multicolumn{8}{|c|}{ LQ Trend 2011-2015 [2015LQ / 2011LQ] } \\
\hline $\begin{array}{l}\text { Distance } \\
\text { Band, } \\
\text { Economic } \\
\text { Group }\end{array}$ & 0.125 & 0.25 & 0.375 & 0.5 & 0.625 & 0.75 & 0.875 & 1 \\
\hline Manufacturing & 0.98 & 0.81 & 1.25 & 0.89 & 1.53 & 0.84 & 1.04 & 2.23 \\
\hline $\begin{array}{l}\text { Light } \\
\text { Industrial }\end{array}$ & 1.18 & 0.87 & 1.07 & 0.86 & 1.17 & 0.99 & 1.03 & 1.25 \\
\hline Retail-Lodge & 0.94 & 1.17 & 1.53 & 0.97 & 1.14 & 0.93 & 0.99 & 1.25 \\
\hline Knowledge & 1.08 & 1 & 1.23 & 0.88 & 1.14 & 0.64 & 1.06 & 1.15 \\
\hline Office & 1.02 & 0.94 & 0.75 & 0.92 & 1.26 & 1.42 & 1.13 & 0.59 \\
\hline Education & 0.95 & 1.12 & 0.88 & 2.05 & 0.53 & 0.71 & 0.9 & 1.01 \\
\hline Health & 0.83 & 1.1 & 1.23 & 0.97 & 1.06 & 0.88 & 0.75 & 1.15 \\
\hline Arts-Ent-Rec & 1.15 & 1.15 & 1.18 & 0.99 & 1.41 & 0.78 & 1.59 & 1.23 \\
\hline
\end{tabular}

Source: Arthur C. Nelson and Robert Hibberd, University of Arizona.

Note: Cells with white bold figures against black backgrounds have LQs or 2015/2011 LQ rations equal to or greater than 1.0 indicating either that an economic group concentrates within one-half (0.50) mile of transit stations (upper part of the table) or trended toward greater concentration from 2011 to 2015. Cells with black bold figures against gray backgrounds indicate that an economic group's performance in one cell is adjacent to others where figures are 
greater than 1.0 and as such suggest potential spillovers from the cell with the higher figure into the lower one where the lower one is also substantially close to 1.0 in its own right. See text for interpretations.

\subsubsection{Commuter Rail Transit Systems}

CRT systems seem to be the forgotten element in land use planning, and economic development. Popular opinion has their role limited to connecting suburban (and exurban) residents to their workers in downtowns or other major centers. Who wants to work near a diesel rail yard where CRT systems embark and disembark?

Table 4.10 shows that nearly all economic groups (except Education) gained workers between 2011 and 2015 over the first 0.20-mile from CRT stations with most of the increasing absorbed in the first (0.125-mile) distance band. (In the second (0.25-mile) distance band, the Office economic group lost workers while Education gained.) While the third distance band (0.375-mile) saw losses in workers and Transit Region share overall, total employment gains to 0.50 -mile accounted for $8 \%$ of CRT Transit Regions' employment growth.

Even more impressive is the trend seen between 2011 and 2015 showing increasing concentrations of employment among all economic groups. They include:

- Manufacturing

- $\quad$ Light Industrial

- Retail-Lodging-Food Service

- Knowledge

- Office

- Education

- Health

- Arts-Entertainment-Recreation

It would seem that there are important economic development opportunities near CRT stations. As we will show in Chapter 5, there are important residential development opportunities as well.

The distribution of workers by wage group is addressed next. 
Table 4.10: Change in Workers by Economic Group and Distance Band from CRT Station, 2011-2015

\begin{tabular}{|c|c|c|c|c|c|c|c|c|}
\hline & 0.125 & 0.25 & 0.375 & 0.50 & 0.625 & 0.75 & 0.875 & 1.00 \\
\hline Economic Group & \multicolumn{8}{|c|}{ Worker Change 2011-2015 } \\
\hline Manufacturing & 4,191 & 2,076 & 59 & $(5,633)$ & 1,976 & 555 & $(877)$ & 606 \\
\hline Light Industrial & 5,011 & 114 & $(2,273)$ & 8,031 & 1,707 & 1,117 & 1,861 & 13,334 \\
\hline Retail-Lodging & 9,295 & 9,100 & $(3,103)$ & 6,858 & 8,698 & 18,159 & 9,497 & 13,334 \\
\hline Knowledge & 7,258 & 5,799 & 9,673 & 15,614 & 13,189 & 17,390 & 7,360 & 21,800 \\
\hline Office & 9,316 & $(6,929)$ & $(4,342)$ & 23,053 & $(10,340)$ & $(8,025)$ & 1,054 & 20,042 \\
\hline Education & $(1,069)$ & 3,560 & $(1,766)$ & 3,429 & 30,169 & $(160)$ & (500) & 2,495 \\
\hline Health & 7,914 & 5,995 & $(289)$ & 7,964 & 7,816 & 7,638 & 7,893 & 3,690 \\
\hline Arts-Ent-Rec & 1,619 & 477 & 682 & $(490)$ & 1,689 & 1,350 & (764) & 3,135 \\
\hline Total & 43,535 & 20,192 & $(1,359)$ & 58,826 & 54,904 & 38,024 & 25,524 & 78,436 \\
\hline Economic Group & \multicolumn{8}{|c|}{ Percent Worker Change 2011-2015 } \\
\hline Manufacturing & $20 \%$ & $10 \%$ & $\mathbf{0 \%}$ & $-17 \%$ & $11 \%$ & $2 \%$ & $-3 \%$ & $2 \%$ \\
\hline Light Industrial & $27 \%$ & $1 \%$ & $-9 \%$ & $19 \%$ & $6 \%$ & $5 \%$ & $7 \%$ & $23 \%$ \\
\hline Retail-Lodging & $22 \%$ & $22 \%$ & $-6 \%$ & $14 \%$ & $19 \%$ & $33 \%$ & $19 \%$ & $23 \%$ \\
\hline Knowledge & $20 \%$ & $16 \%$ & $29 \%$ & $36 \%$ & $25 \%$ & $34 \%$ & $15 \%$ & $37 \%$ \\
\hline Office & $18 \%$ & $-13 \%$ & $-5 \%$ & $23 \%$ & $-9 \%$ & $-8 \%$ & $1 \%$ & $20 \%$ \\
\hline Education & $-4 \%$ & $13 \%$ & $-18 \%$ & $32 \%$ & $244 \%$ & $-1 \%$ & $-3 \%$ & $10 \%$ \\
\hline Health & $17 \%$ & $13 \%$ & $-1 \%$ & $29 \%$ & $32 \%$ & $23 \%$ & $17 \%$ & $10 \%$ \\
\hline Arts-Ent-Rec & $64 \%$ & $19 \%$ & $12 \%$ & $-8 \%$ & $64 \%$ & $26 \%$ & $-8 \%$ & $46 \%$ \\
\hline Total & $18 \%$ & $8 \%$ & $-1 \%$ & $19 \%$ & $18 \%$ & $13 \%$ & $8 \%$ & $21 \%$ \\
\hline Economic Group & \multicolumn{8}{|c|}{ Transit Region Share of Economic Group Worker Change 2011-2015 } \\
\hline Manufacturing & $7 \%$ & $3 \%$ & $\mathbf{0 \%}$ & $-9 \%$ & $3 \%$ & $1 \%$ & $-1 \%$ & $1 \%$ \\
\hline Light Industrial & $4 \%$ & $0 \%$ & $-2 \%$ & $6 \%$ & $1 \%$ & $1 \%$ & $1 \%$ & $3 \%$ \\
\hline Retail-Lodging & $2 \%$ & $2 \%$ & $-1 \%$ & $2 \%$ & $2 \%$ & $4 \%$ & $2 \%$ & $3 \%$ \\
\hline Knowledge & $3 \%$ & $2 \%$ & $4 \%$ & $6 \%$ & $5 \%$ & $7 \%$ & $3 \%$ & $8 \%$ \\
\hline Office & $4 \%$ & $-3 \%$ & $-2 \%$ & $10 \%$ & $-4 \%$ & $-3 \%$ & $0 \%$ & $8 \%$ \\
\hline Education & $-29 \%$ & $96 \%$ & $-48 \%$ & $93 \%$ & $815 \%$ & $-4 \%$ & $-14 \%$ & $67 \%$ \\
\hline Health & $3 \%$ & $2 \%$ & $-0 \%$ & $3 \%$ & $3 \%$ & $3 \%$ & $3 \%$ & $1 \%$ \\
\hline Arts-Ent-Rec & $8 \%$ & $2 \%$ & $3 \%$ & $-2 \%$ & $9 \%$ & $7 \%$ & $-4 \%$ & $16 \%$ \\
\hline Total & $3 \%$ & $1 \%$ & $-0 \%$ & $4 \%$ & $4 \%$ & $3 \%$ & $2 \%$ & $5 \%$ \\
\hline
\end{tabular}

Source: Arthur C. Nelson and Robert Hibberd, University of Arizona. 
Table 4.11: Location Quotients by Economic Group for 2015 and LQ Trends 2011-2015 by Economic Group by Distance Band from CRT Station

\begin{tabular}{|c|c|c|c|c|c|c|c|c|}
\hline & \multicolumn{8}{|c|}{ Location Quotients 2015} \\
\hline $\begin{array}{l}\text { Distance } \\
\text { Band, } \\
\text { Economic } \\
\text { Group }\end{array}$ & 0.125 & 0.25 & 0.375 & 0.5 & 0.625 & 0.75 & 0.875 & 1 \\
\hline Manufacturing & 1.07 & 0.77 & 0.62 & 0.87 & 0.68 & 0.82 & 0.88 & 0.99 \\
\hline $\begin{array}{l}\text { Light } \\
\text { Industrial }\end{array}$ & 0.81 & 0.83 & 0.91 & 1.36 & 0.88 & 0.72 & 0.88 & 0.81 \\
\hline $\begin{array}{l}\text { Retail- } \\
\text { Lodging }\end{array}$ & 0.82 & 0.95 & 0.85 & 0.71 & 0.71 & 1.02 & 0.82 & 0.81 \\
\hline Knowledge & 1.24 & 1.56 & 1.41 & 1.28 & 1.51 & 1.63 & 1.33 & 1.63 \\
\hline Office & 0.88 & 0.94 & 1.49 & 1.4 & 1.24 & 1.13 & 1.09 & 1.23 \\
\hline Education & 1.09 & 1.49 & 0.38 & 0.45 & 1.4 & 0.4 & 0.67 & 0.8 \\
\hline Health & 1.37 & 0.57 & 0.66 & 0.71 & 0.67 & 0.9 & 1.17 & 0.72 \\
\hline \multirow[t]{2}{*}{ Arts-Ent-Rec } & 0.64 & 1.44 & 1.13 & 0.7 & 0.55 & 0.88 & 1.21 & 1.11 \\
\hline & \multicolumn{8}{|c|}{ LQ Trend 2011-2015 [2015LQ / 2011LQ] } \\
\hline $\begin{array}{l}\text { Distance } \\
\text { Band, } \\
\text { Economic } \\
\text { Group }\end{array}$ & 0.125 & 0.25 & 0.375 & 0.5 & 0.625 & 0.75 & 0.875 & 1 \\
\hline Manufacturing & 1.07 & 1.1 & 1.06 & 0.73 & 0.98 & 0.95 & 0.93 & 0.89 \\
\hline $\begin{array}{l}\text { Light } \\
\text { Industrial }\end{array}$ & 1.09 & 0.94 & 0.92 & 1.01 & 0.9 & 0.94 & 0.99 & 0.99 \\
\hline $\begin{array}{l}\text { Retail- } \\
\text { Lodging }\end{array}$ & 1 & 1.07 & 0.91 & 0.92 & 0.97 & 1.13 & 1.06 & 0.99 \\
\hline Knowledge & 0.96 & 0.99 & 1.23 & 1.09 & 1 & 1.13 & 1.01 & 1.08 \\
\hline Office & 1.03 & 0.86 & 0.99 & 1.06 & 0.79 & 0.84 & 0.96 & 1.03 \\
\hline Education & 0.9 & 1.13 & 0.91 & 1.22 & 3.2 & 0.96 & 0.99 & 1 \\
\hline Health & 0.95 & 1.24 & 0.95 & 1.03 & 1.07 & 1.04 & 1.04 & 0.88 \\
\hline Arts-Ent-Rec & 1.45 & 1.02 & 1.17 & 0.81 & 1.44 & 1.16 & 0.88 & 1.26 \\
\hline
\end{tabular}

Source: Arthur C. Nelson and Robert Hibberd, University of Arizona.

Note: Cells with white bold figures against black backgrounds have LQs or 2015/2011 LQ rations equal to or greater than 1.0 indicating either that an economic group concentrates within one-half (0.50) mile of transit stations (upper part of the table) or trended toward greater concentration from 2011 to 2015. Cells with black bold figures against gray backgrounds indicate that an economic group's performance in one cell is adjacent to others where figures are greater than 1.0 and as such suggest potential spillovers from the cell with the higher figure into 
the lower one where the lower one is also substantially close to 1.0 in its own right. See text for interpretations.

\subsubsection{Wage Group Findings}

Tables 4.12 through 4.15 present changes in the number of workers between 2011 and 2015 by distance band for LRT, BRT, SCT and CRT system, respectively. We find remarkably similar trends among all systems other than CRT, notably:

- The innermost (0.125-mile) distance band accounted for $10 \%, 13 \%$ and $13 \%$ of the net change in upper-wage workers, respectively for the entire transit region. Yet, we see from Table 4.16 that these distance bands comprise a very small share of the total transit county urban land area at $0.3 \%$. In other words, this distance band absorbs a ratio of 32 , 11 and 31 times the share in the change in workers than the land area of this distance band.

- While middle-wage workers also gain share of workers in the innermost distance band, lower-wage workers either absorb the smallest share or lose share, being displaced. Notably, for LRT systems, lower-wage workers appear to be displaced from the innermost (0.125-mile) distance band, perhaps to areas beyond 0.50-mile.

- All FRT systems absorbed magnitudes higher shares of the total change in workers in the innermost (0.125-mile) distance band.

- When assessing FRT systems individually it appears that thresholds for absorbing transit region workers are these distance bands, where the absorption rate is the lowest and closest to transit stations:

$$
\begin{aligned}
\mathrm{LRT} & =0.25 \text {-mile } \\
\mathrm{BRT} & =0.25 \text {-mile } \\
\mathrm{SCT} & =0.125 \text {-mile } \\
\mathrm{CRT} & =0.25 \text {-mile }
\end{aligned}
$$

We will see in Chapter 5 that there may be competition between workers and residents especially in the two innermost distance bands. 
Table 4.12: Change in Workers by Wage Group and Distance Band from LRT Station, 2011-2015

\begin{tabular}{|c|c|c|c|c|c|c|c|c|}
\hline LRT Systems & 0.125 & 0.25 & 0.375 & 0.50 & 0.625 & 0.75 & 0.875 & 1.00 \\
\hline Wage Group & \multicolumn{8}{|c|}{ Worker Change 2011-2015 } \\
\hline Upper Wage & 52,855 & 9,347 & 27,005 & 17,873 & 12,150 & 44,463 & 8,730 & 2,559 \\
\hline Middle Wage & 9,965 & 3,866 & 7,367 & 15,290 & 8,352 & 22,108 & 10,836 & $(8,407)$ \\
\hline Lower Wage & $(30,045)$ & 7,904 & 11,913 & 12,205 & 43,961 & 46,241 & 10,388 & 10,563 \\
\hline Total & 32,775 & 21,117 & 46,285 & 45,368 & 64,463 & 112,812 & 29,954 & 4,715 \\
\hline Wage Group & \multicolumn{8}{|c|}{ Percent Worker Change 2011-2015 } \\
\hline Upper Wage & $10 \%$ & $3 \%$ & $18 \%$ & $14 \%$ & $9 \%$ & $37 \%$ & $10 \%$ & $3 \%$ \\
\hline Middle Wage & $2 \%$ & $2 \%$ & $4 \%$ & $9 \%$ & $5 \%$ & $24 \%$ & $12 \%$ & $-12 \%$ \\
\hline Lower Wage & $-6 \%$ & $3 \%$ & $6 \%$ & $7 \%$ & $26 \%$ & $27 \%$ & $9 \%$ & $9 \%$ \\
\hline Total & $2 \%$ & $3 \%$ & $9 \%$ & $10 \%$ & $14 \%$ & $29 \%$ & $10 \%$ & $2 \%$ \\
\hline Wage Group & \multicolumn{8}{|c|}{ Share of Wage Group Worker Change 2011-2015 } \\
\hline Upper Wage & $10 \%$ & $2 \%$ & $5 \%$ & $3 \%$ & $2 \%$ & $2 \%$ & $2 \%$ & $0 \%$ \\
\hline Middle Wage & $3 \%$ & $1 \%$ & $2 \%$ & $4 \%$ & $2 \%$ & $4 \%$ & $3 \%$ & $-2 \%$ \\
\hline Lower Wage & $-5 \%$ & $1 \%$ & $2 \%$ & $2 \%$ & $8 \%$ & $-0 \%$ & $2 \%$ & $2 \%$ \\
\hline Total & $2 \%$ & $1 \%$ & $3 \%$ & $3 \%$ & $4 \%$ & $2 \%$ & $2 \%$ & $0 \%$ \\
\hline
\end{tabular}

Table 4.13: Change in Workers by Wage Group and Distance Band from BRT Station, 2011-2015

\begin{tabular}{|c|c|c|c|c|c|c|c|c|}
\hline BRT Systems & 0.125 & 0.25 & 0.375 & 0.50 & 0.625 & 0.75 & 0.875 & 1.00 \\
\hline Wage Group & \multicolumn{8}{|c|}{ Worker Change 2011-2015 } \\
\hline Upper Wage & 31,149 & 9,452 & 623 & 11,694 & $(1,143)$ & 5,632 & 4,662 & 7,698 \\
\hline Middle Wage & 26,323 & $(13,217)$ & $(5,318)$ & 109 & 17,943 & 5,719 & 4,198 & $(5,993)$ \\
\hline Lower Wage & 13,965 & 23,749 & 4,937 & 21,631 & 18,517 & 1,056 & 1,309 & 2,657 \\
\hline Total & 71,437 & 19,984 & 242 & 33,434 & 35,317 & 12,407 & 10,169 & 4,362 \\
\hline Wage Group & \multicolumn{8}{|c|}{ Percent Worker Change 2011-2015 } \\
\hline Upper Wage & $7 \%$ & $7 \%$ & $1 \%$ & $16 \%$ & $-2 \%$ & $12 \%$ & $11 \%$ & $16 \%$ \\
\hline Middle Wage & $7 \%$ & $-12 \%$ & $-5 \%$ & $0 \%$ & $29 \%$ & $10 \%$ & $10 \%$ & $-8 \%$ \\
\hline Lower Wage & $2 \%$ & $14 \%$ & $4 \%$ & $19 \%$ & $16 \%$ & $1 \%$ & $2 \%$ & $3 \%$ \\
\hline Total & $4 \%$ & $5 \%$ & $0 \%$ & $14 \%$ & $14 \%$ & $7 \%$ & $7 \%$ & $2 \%$ \\
\hline Wage Group & \multicolumn{8}{|c|}{ Share of Wage Group Worker Change 2011-2015 } \\
\hline Upper Wage & $13 \%$ & $4 \%$ & $0 \%$ & $5 \%$ & $-0 \%$ & $2 \%$ & $2 \%$ & $3 \%$ \\
\hline Middle Wage & $14 \%$ & $-7 \%$ & $-3 \%$ & $0 \%$ & $10 \%$ & $3 \%$ & $2 \%$ & $-3 \%$ \\
\hline Lower Wage & $4 \%$ & $7 \%$ & $1 \%$ & $6 \%$ & $5 \%$ & $0 \%$ & $0 \%$ & $1 \%$ \\
\hline Total & $9 \%$ & $3 \%$ & $0 \%$ & $4 \%$ & $5 \%$ & $2 \%$ & $1 \%$ & $1 \%$ \\
\hline
\end{tabular}


Table 4.14: Change in Workers by Wage Group and Distance Band from SCT Station, 2011-2015

\begin{tabular}{|c|c|c|c|c|c|c|c|c|}
\hline SCT Systems & 0.125 & 0.25 & 0.375 & 0.50 & 0.625 & 0.75 & 0.875 & 1.00 \\
\hline Wage Group & \multicolumn{8}{|c|}{ Worker Change 2011-2015 } \\
\hline Upper Wage & 25,185 & $(6,239)$ & 9,559 & $(1,994)$ & 2,681 & $(143)$ & $(46)$ & 758 \\
\hline Middle Wage & 11,440 & $(6,307)$ & 15 & 204 & (339) & 11,019 & 960 & $(8,429)$ \\
\hline Lower Wage & 6,029 & 96 & $(11,208)$ & 16,332 & $(11,035)$ & 2,687 & 3,661 & (573) \\
\hline Total & 42,654 & $(12,450)$ & $(1,634)$ & 14,542 & $(8,693)$ & 13,563 & 4,575 & $(8,244)$ \\
\hline Wage Group & \multicolumn{8}{|c|}{ Percent Worker Change 2011-2015 } \\
\hline Upper Wage & $27 \%$ & $-7 \%$ & $18 \%$ & $-5 \%$ & $7 \%$ & $-1 \%$ & $-0 \%$ & $4 \%$ \\
\hline Middle Wage & $13 \%$ & $-10 \%$ & $0 \%$ & $1 \%$ & $-1 \%$ & $113 \%$ & $14 \%$ & $-56 \%$ \\
\hline Lower Wage & $5 \%$ & $0 \%$ & $-11 \%$ & $62 \%$ & $-42 \%$ & $25 \%$ & $20 \%$ & $-3 \%$ \\
\hline Total & $14 \%$ & $-6 \%$ & $-1 \%$ & $15 \%$ & $-9 \%$ & $40 \%$ & $12 \%$ & $-15 \%$ \\
\hline Wage Group & \multicolumn{8}{|c|}{ Share of Wage Group Worker Change 2011-2015 } \\
\hline Upper Wage & $13 \%$ & $-3 \%$ & $5 \%$ & $-1 \%$ & $1 \%$ & $-0 \%$ & $-0 \%$ & $0 \%$ \\
\hline Middle Wage & $9 \%$ & $-5 \%$ & $0 \%$ & $0 \%$ & $-0 \%$ & $8 \%$ & $1 \%$ & $-6 \%$ \\
\hline Lower Wage & $2 \%$ & $0 \%$ & $-4 \%$ & $6 \%$ & $-4 \%$ & $1 \%$ & $1 \%$ & $-0 \%$ \\
\hline Total & $7 \%$ & $-2 \%$ & $-0 \%$ & $3 \%$ & $-2 \%$ & $2 \%$ & $1 \%$ & $-1 \%$ \\
\hline
\end{tabular}

Table 4.15: Change in Workers by Wage Group and Distance Band from CRT Station, 2011-2015

\begin{tabular}{|c|c|c|c|c|c|c|c|c|}
\hline CRT Systems & 0.125 & 0.25 & 0.375 & 0.50 & 0.625 & 0.75 & 0.875 & 1.00 \\
\hline Wage Group & \multicolumn{8}{|c|}{ Worker Change 2011-2015 } \\
\hline Upper Wage & 15,546 & 8,886 & 4,902 & 26,192 & 11,970 & 26,573 & 11,087 & 35,354 \\
\hline Middle Wage & 14,378 & $(6,475)$ & $(21,855)$ & 19,313 & $(1,253)$ & 12,955 & 5,292 & 7,496 \\
\hline Lower Wage & 21,269 & 22,265 & 1,484 & 12,913 & 8,496 & $(3,454)$ & 9,499 & 28,682 \\
\hline Total & 51,193 & 24,676 & $(15,469)$ & 58,418 & 19,213 & 36,074 & 25,878 & 71,532 \\
\hline Wage Group & \multicolumn{8}{|c|}{ Percent Worker Change 2011-2015 } \\
\hline Upper Wage & $17 \%$ & $9 \%$ & $6 \%$ & $22 \%$ & $10 \%$ & $24 \%$ & $9 \%$ & $23 \%$ \\
\hline Middle Wage & $20 \%$ & $-13 \%$ & $-22 \%$ & $19 \%$ & $-1 \%$ & $17 \%$ & $6 \%$ & $10 \%$ \\
\hline Lower Wage & $23 \%$ & $19 \%$ & $1 \%$ & $13 \%$ & $8 \%$ & $-3 \%$ & $8 \%$ & $22 \%$ \\
\hline Total & $20 \%$ & $9 \%$ & $-5 \%$ & $18 \%$ & $6 \%$ & $11 \%$ & $8 \%$ & $20 \%$ \\
\hline Wage Group & \multicolumn{8}{|c|}{ Share of Wage Group Worker Change 2011-2015 } \\
\hline Upper Wage & $3 \%$ & $2 \%$ & $1 \%$ & $5 \%$ & $2 \%$ & $5 \%$ & $2 \%$ & $7 \%$ \\
\hline Middle Wage & $4 \%$ & $-2 \%$ & $-7 \%$ & $6 \%$ & $-0 \%$ & $4 \%$ & $2 \%$ & $2 \%$ \\
\hline Lower Wage & $4 \%$ & $4 \%$ & $0 \%$ & $2 \%$ & $2 \%$ & $-1 \%$ & $2 \%$ & $5 \%$ \\
\hline Total & $4 \%$ & $2 \%$ & $-1 \%$ & $4 \%$ & $1 \%$ & $3 \%$ & $2 \%$ & $5 \%$ \\
\hline
\end{tabular}


Table 4.16: Summary Change in Workers by Wage Group for 0.125 and 0.50 Distance Bands with Transit Region Share of Change for All Stations, 2011-2015

\begin{tabular}{|c|c|c|c|}
\hline 0.125-Mile & Upper Wage & Middle Wage & Lower Wage \\
\hline & & \multicolumn{2}{|c|}{ Light Rail Transit Change 2011-2015 } \\
\hline UA & $0.3 \%$ & $0.3 \%$ & $0.3 \%$ \\
\hline Worker Share & $9.9 \%$ & $2.5 \%$ & $-5.2 \%$ \\
\hline \multirow[t]{2}{*}{ Ratio } & 31.5 & 8.1 & -16.5 \\
\hline & & \multicolumn{2}{|c|}{ Bus Rapid Transit Change 2011-2015 } \\
\hline UA & $1.2 \%$ & $1.2 \%$ & $1.2 \%$ \\
\hline Worker Share & $13.1 \%$ & $14.0 \%$ & $4.1 \%$ \\
\hline \multirow[t]{2}{*}{ Ratio } & 10.9 & 11.7 & 3.4 \\
\hline & & \multicolumn{2}{|c|}{ Streetcar Transit Change 2011-2015 } \\
\hline UA & $0.4 \%$ & $0.4 \%$ & $0.4 \%$ \\
\hline Worker Share & $13.1 \%$ & $8.8 \%$ & $2.4 \%$ \\
\hline \multirow[t]{2}{*}{ Ratio } & 30.3 & 20.3 & 5.5 \\
\hline & & \multicolumn{2}{|c|}{ Commuter Rail Transit Change 2011-2015 } \\
\hline UA & $0.1 \%$ & $0.1 \%$ & $0.1 \%$ \\
\hline Worker Share & $3.1 \%$ & $4.4 \%$ & $3.8 \%$ \\
\hline Ratio & 34.2 & 48.4 & 41.5 \\
\hline \multirow[t]{2}{*}{ 0.50-Mile } & Upper Wage & Middle Wage & Lower Wage \\
\hline & & \multicolumn{2}{|c|}{ Light Rail Transit Change 2011-2015 } \\
\hline UA & $3.1 \%$ & $3.1 \%$ & $3.1 \%$ \\
\hline Worker Share & $20.1 \%$ & $9.3 \%$ & $0.3 \%$ \\
\hline \multirow[t]{2}{*}{ Ratio } & 6.4 & 3.0 & 0.1 \\
\hline & & \multicolumn{2}{|c|}{ Bus Rapid Transit Change 2011-2015 } \\
\hline UA & $7.0 \%$ & $7.0 \%$ & $7.0 \%$ \\
\hline Worker Share & $29.7 \%$ & $4.2 \%$ & $19.0 \%$ \\
\hline \multirow[t]{2}{*}{ Ratio } & 4.2 & 0.6 & 2.7 \\
\hline & & \multicolumn{2}{|c|}{ Streetcar Transit Change 2011-2015 } \\
\hline UA & $2.1 \%$ & $2.1 \%$ & $2.1 \%$ \\
\hline Worker Share & $13.7 \%$ & $4.1 \%$ & $4.4 \%$ \\
\hline \multirow[t]{2}{*}{ Ratio } & 6.5 & 1.9 & 2.1 \\
\hline & & \multicolumn{2}{|c|}{ Commuter Rail Transit Change 2011-2015 } \\
\hline UA & $1.4 \%$ & $1.4 \%$ & $1.4 \%$ \\
\hline Worker Share & $11.1 \%$ & $1.6 \%$ & $10.3 \%$ \\
\hline Ratio & 8.1 & 1.2 & 7.5 \\
\hline
\end{tabular}




\subsection{SUMMARY AND IMPLICATIONS}

One objective of transit policy makers seems to include expanding lower and middle income workers near transit stations. There is an implied assumption that transit stations per se will increase workers near them though there is concern that only higher paying workers might increase. There is the hope that by increasing lower and middle wage workers, workers-housing balance workers-labor force balance can also be improved (see Chapter 7).

In Chapter 3, we showed the kinds of workers that may be attracted to, or repelled from, transit station proximity by type of fixed route transit system, the era of commencement, and during three discrete time periods before, during and after the Great Recession. Based on the analysis presented in this chapter, we surmise that going forward from the Great Recession:

- LRT stations may gain share in upper wage workers but lose share among middle and lower wage workers especially in the 0.50 mile distance band perhaps because people and housing are displacing workers from the innermost ( 0.25 mile) distance band;

- BRT stations do not seem poised to gain share in workers among any of the wage groups in the innermost ( 0.25 mile) distance band but may gain share of workers among the upper and middle wage categories (see Chapters 2 and 3 for possible reasons);

- SCT stations may be poised to gain share of regional worker change among upper and lower wage workers also in just the innermost ( 0.25 mile) distance but lose share among middle wage workers in that band, and lose regional share of worker change among all wage categories beyond; and

- CRT stations appear to be poised to gain regional share of workers among all wage categories in the innermost ( 0.25 mile) distance band though perhaps only upper wage workers in the next (0.50 mile) distance band.

The link between transit station proximity and changes in the regional share of people and housing, and commuting patterns will be addressed in Chapters 5 and 6 while the link between transit station proximity on workers-housing balance, and workers-labor force balance over time will be addressed in Chapter 7. 


\section{REFERENCES}

Bania, Neil, Laura Leete, and Claudia Coulton (2008). Worker access, employment and earnings: Outcomes for welfare leavers in a US urban labour market. Urban Studies 45(11): 2179-2202.

Blumenberg, Evelyn A., Paul M. Ong, and Andrew Mondschein (2002). Uneven access to opportunities: Welfare recipients, workers, and employment support services in Los Angeles. University of California Transportation Center.

Blumenberg, Evelyn, and Michael Manville (2004). Beyond the spatial mismatch: welfare recipients and transportation policy. Journal of Planning Literature 19(2): 182-205.

Cervero, Robert, Onésimo Sandoval, and John Landis (2002). Transportation as a stimulus of welfare-to-work private versus public mobility. Journal of Planning Education and Research 22(1): 50-63.

Fan, Yingling, Andrew Guthrie, and David Levinson (2012) Impact of Light Rail Implementation on Labor Market Accessibility: A Transportation Equity Perspective. Journal of Transport and Land Use 5(3) 28-39.

Giuliano, G. (2004). Land use impacts of transportation investments: Highway and transit. In S. Hanson and G. Giuliano (Eds.), The Geography of Urban Transportation, 3rd Edition. New York: Guilford Press.

Higgins, Christopher D. and Pavlos S. Kanaroglou (2015) 40 Years of Modelling Rail Transit's Land Value Uplift in North America: Diverse Methods, Differentiated Outcomes, Debatable Assumptions, and Future Directions. Transportation Research Record.

Institute for Transportation \& Development Policy. Best Practices 2013.

https://www.itdp.org/library/standards-and-guides/the-bus-rapid-transit-standard/best-practices-2013/

Kain, John F. (1968) Housing segregation, negro employment, and metropolitan decentralization. The Quarterly Journal of Economics: 175-197.

Kain, John F. (1992). The Spatial Mismatch Hypothesis: Three Decades Later. Housing Policy Debate 3(2): 371-392.

Kawabata, Mizuki (2002). Worker access and work among autoless adults in welfare in Los Angeles. Working Paper Number 40. Los Angeles: The Ralph and Goldy Lewis Center for Regional Policy Studies.

Kawabata, Mizuki (2003). Worker access and employment among low-skilled autoless workers in US metropolitan areas. Environment and Planning A 35(9): 1651-1668.

Leadership Conference Education Fund (2011a). Where we Need to Go: A Civil Rights Road Map for Transportation Equity. Washington, DC: Leadership Conference Education Fund. 
Leadership Conference Education Fund (2011b). Getting to Work: Transportation Policy and Access to Work. Washington, DC: Leadership Conference Education Fund.

McKenzie, Brian S. (2013) Neighborhood access to transit by race, ethnicity, and poverty in Portland, OR. City \& Community 12, no. 2 (2013): 134-155.

Nelson, Arthur C. (2013). Reshaping metropolitan America: Development trends and opportunities to 2030. Washington, DC: Island Press, 2013.

Nelson, Arthur C. (2014). Foundations of Real Estate Development Finance: A Guide for Public-Private Partnerships. Washington, DC: Island Press.

Nelson, Arthur C., Bruce Appleyard, Shyam Kannan, Reid Ewing, Matt Miller, Dejan Eskic (2013). Bus Rapid Transit and Economic Development: Case Study of the Eugene-Springfield BRT System. Journal of Public Transportation 16(3): 41-57.

Nelson, Arthur C., Matt Miller, Joanna P. Ganning, Philip Stoker, Jenny H. Liu, and Reid Ewing. (2014). Transit and Economic Resilience. Transportation Research Board 94th Annual Meeting, no. $15-5474$.

Nelson, Arthur C. and Joanna P. Ganning (2015). National Study of BRT Development Outcomes. Portland, OR: National Institute of Transportation and Communities.

Ong, Paul M., and Douglas Houston (2002). Transit, Employment and Women on Welfare. Urban Geography 23(4): 344-364.

Ong, P., M. and D. Miller. (2005). Spatial and Transportation Mismatch in Los Angeles. Journal of Planning Education and Research 25(1): 43-56.

Sanchez, T. W. and M. Brenman (2008). A Right to Transportation: Moving to Equity. Chicago, IL: American Planning Association.

Sanchez, Thomas W. (2008) Poverty, policy, and public transportation." Transportation Research Part A: Policy and Practice 42(5): 833-841.

Sanchez, Thomas W., Qing Shen, and Zhong-Ren Peng (2004). Transit mobility, workers access and lowincome labour participation in US metropolitan areas. Urban Studies 41(7): 1313-1331.

Sanchez, Thomas W. (1999). The connection between public transit and employment: the cases of Portland and Atlanta. Journal of the American Planning Association 65, no. 3 (1999): 284-296.

Sen, Ashish, Paul Metaxatos, Siim Sööt, and Vonu Thakuriah (1999). Welfare reform and spatial matching between clients and workers. Papers in Regional Science 78(2): 195-211.

Thakuriah, Piyushimita, and Paul Metaxatos (2000). Effect of residential location and access to transportation on employment opportunities. Transportation Research Record: Journal of the Transportation Research Board 1726: 24-32. 


\subsection{THE LINK BETWEEN TRANSIT STATIONS AND PEOPLE, HOUSEHOLD AND HOUSING}

\subsection{OVERVIEW}

Transit policy seems intent on having fixed guideway transit (FGT) systems (a) improve the accessibility of people to jobs especially by increasing transit's share of mode choice to work, (b) attracting people to live near FGT stations, and (c) improving the supply of jobs especially with respect to low and moderate wage accessibility over time. But do they?

This chapter reports what may be the first effort to weave otherwise disparate transit planning objectives into an overall assessment of the extent to which FGT systems perform as desired over time. Specifically, it applies economic base analysis to more than 40 light rail transit (LRT), bus rapid transit (BRT), streetcar transit (SCT), and commuter rail transit (CRT) systems operating in more than 30 metropolitan areas to estimate shifts in the share of:

- $\quad$ People by minority status;

- Households by type and householder age; and

- Housing by tenure (owner/renter).

The analysis estimates outcomes with respect to one-eighth (0.125), one-quarter $(0.25)$, one-half (0.50), three-quarters (0.75) and one (1.00) mile buffers of FGT stations between 2000 and 2009 and recovery from 2010 to 2016.

Overall, we find positive shifts in the share of regional population and household change mostly favoring locations closest to FGT stations though positive effects are seen in all the distance bands. This is a remarkable finding, however, considering the land area around stations increases as distances from them increase, suggesting that FGT stations have a kind of gravitational attraction on people and housing. As suggested in Chapters 2 and 3, people may be attracted to station areas to such an extent that they are displacing jobs to locations farther way from stations. 


\subsection{INTRODUCTION}

Transit systems, and especially transit oriented development, offer many promises related to people and housing. However, for the most part there is very little research assessing whether transit and the stations serving them are effective in attracting new residents and influencing housing choices. Some studies address mostly individual station areas but not of metropolitan areas as a whole (Cervero and Seskin, 1995; Cervero et al., 2004; Chapple and Loukaitou-Sideris 2019; Kolko, 2011). In particular, no study systematically analyzes the change in population and housing associated with fixed guideway transit systems, such as light rail transit (LRT), streetcar transit (SCT) and bus rapid transit (BRT) systems in the U.S. The only metropolitan-scale studies addressing the influence of BRT systems on population and housing are from outside the U.S.

(Carrigan et al., 2013; Cervero, 2013).

Of interest in this chapter is the extent to which LRT, SCT and BRT station areas attract population, households and housing consistent with expectations (Belzer et al., 2007; Belzer and Poticha, 2010; Belzer et al, 2011; Carrigan et al., 2013; Cervero et al., 2004; Chapple and Loukaitou-Sideris, 2019; Dawkins and Buehler, 2010; Dawkins and Moeckel, 2016). Indeed, only one study addresses population and housing change for all transit systems in the U.S. - the Center for Transit Oriented Development (2014) — but it does not differentiate by type of system, distance from transit stations, or provide detail on the race/ethnicity of people, households by age and type and income, and housing based on tenure. This article helps close an important gap in the transit literature, especially related to LRT, BRT, SCT and CRT systems.

This chapter begins with the research question, outlines the analytic framework and presents results for each type of transit system, and concludes with a summary.

\subsection{RESEARCH QUESTION AND DESIGN}

The following research question guides research reported in this chapter:

Relative to the counties within which transit systems operate ("transit counties"), are there shifts in the regional share of people and housing over time with respect to FGT station proximity, particularly with respect to change in:

- population by race,

- households by children present,

- householder age, and

- housing by tenure?

The research question lends itself to pre-post quasi-experimental design. Data, study periods, and analytic strategy are reviewed next. 


\subsubsection{Data}

For most of the analysis, we use decennial census data for 2000 and 2010, and American Community Survey (ACS) data for 2009 and 2016, compiled from the National Historical GIS (NHGIS) data files available online (Manson, et al. 2018).

\subsubsection{Study Periods}

We evaluate shift in shares of demographic, housing, commuting and wage change over two discrete time periods extending from before the Great Recession (2008-2009) and afterward:

- 2000-2009 covers the period of relatively constant growth from the early 2000s into the Great Recession which technically ended in 2009, but which was followed by stagnant recovery to about 2011.

- 2010-2016 covers the period after the Great Recession which we call "post-recession.” This is the post-test period. Based on our theory, FGT station areas should capture a higher share of the shift of regional demographic, housing, mode choice, and jobs by wage categories than their metropolitan areas as a whole. Whether this share in the shift would be higher than predicted during the Great Recession we cannot say, but we can predict it should be higher than the pre-recession period.

\subsubsection{Fixed Guideway Transit Systems Studied}

Table 5.1 shows the FGT systems we include in our analysis, organized by the period of time in which they commenced operations. We excluded systems in the largest metropolitan areas (such as New York City, Chicago, Los Angeles) or metropolitan areas with a complex web of public transit (such as Boston, Philadelphia, San Francisco-Oakland) because we wanted to estimate outcomes associated with individual systems independent of the influences of multiple systems. 
Table 5.1: Fixed Guideway Transit Systems Used in Analysis

\begin{tabular}{|c|c|c|c|c|c|c|c|}
\hline Light Rail Transit & & Bus Rapid Transit & & Streetcar Transit & & Commuter Rail T & \\
\hline $1^{\text {st }}$ Generation & Year & Pioneer & Year & $1^{\text {st }}$ Generation & Year & $1^{\text {st }}$ Generation & Year \\
\hline Buffalo & 1984 & Pittsburgh & 1977 & Little Rock & 2004 & Dallas-Fort Worth & 1996 \\
\hline Cleveland & 1980 & Pre-Recession & & Portland & 2001 & Miami Tri-Rail & 1989 \\
\hline Pittsburgh & 1984 & Eugene-Springfield & 2007 & Seattle & 2007 & Minneapolis & 1997 \\
\hline Portland & 1986 & Kansas City & 2005 & Tacoma & 2003 & San Diego & 1995 \\
\hline Sacramento & 1987 & Las Vegas & 2004 & Tampa & 2002 & San Jose-Stockton & 1998 \\
\hline San Diego & 1981 & Stockton & 2007 & $2^{\text {nd }}$ Generation & & Seattle-Tacoma & 2000 \\
\hline San Jose & 1987 & Great Recession & & Atlanta & 2014 & $2^{\text {nd }}$ Generation & \\
\hline $2^{\text {nd }}$ Generation & & Cleveland & 2008 & Dallas & 2015 & Albuquerque & 2006 \\
\hline Dallas & 1996 & Nashville & 2009 & Salt Lake City & 2013 & Austin & 2010 \\
\hline Denver & 1994 & Phoenix & 2009 & Tucson & 2014 & Nashville & 2006 \\
\hline Salt Lake City & 1999 & Reno & 2010 & & & Orlando & 2014 \\
\hline St. Louis & 1993 & Salt Lake City & 2008 & & & Portland & 2009 \\
\hline $3^{\text {rd }}$ Generation & & Seattle & 2010 & & & Salt Lake City & 2008 \\
\hline Charlotte & 2007 & Post-Recession & & & & & \\
\hline Houston & 2004 & San Antonio & 2012 & & & & \\
\hline Minneapolis-St. Paul & 2004 & San Diego & 2014 & & & & \\
\hline Norfolk & 2011 & & & & & & \\
\hline Phoenix & 2008 & & & & & & \\
\hline Seattle & 2003 & & & & & & \\
\hline
\end{tabular}




\subsubsection{Analytic Approach}

Given that change in employment share over time is our principal interest, we choose shift-share analysis as our analytic approach. This is similar to the approach we used to evaluate shifts in shares of jobs around bus rapid transit stations in the Eugene-Springfield (Oregon) metropolitan area. We adapt that analytic discussion to the present analysis (Nelson et al., 2013).

Shift-share analysis assigns the change or shift in the share or concentration of jobs with respect to the region, other economic sectors, and the local area. The "region" can be any level of geography and is often the nation or the state. In our case, it is where we want to see whether there are intrametropolitan shifts in the share of demographic, housing, mode choice, and workers by wage group changes with respect to transit station proximity. Our region is the "Transit Region" meaning those counties within which FGT systems operated during the entire study period. The "local" area is often a city or county or even state, but it can be any geographic unit that is smaller than the region. Our local areas are the FGT station areas within 0.125 (oneeighth) mile, 0.250 (one quarter) mile, 0.500 (one half) mile, 0.750 (three quarters) mile, and 1.000 mile of the nearest FGT station. As shifts in the share of activities may vary because of changes in demographic, housing, mode choice, and job by wage mixes, there is also an "industry mix" adjustment that we call "sector mix". Using notations by the Carnegie Mellon Center for Economic Development (no date), the shift-share formula is:

$$
\mathrm{SS}_{\mathrm{i}}=\mathrm{TR}_{\mathrm{i}}+\mathrm{SM}_{\mathrm{i}}+\mathrm{FGT}_{\mathrm{i}}
$$

Where

$$
\begin{aligned}
& \mathrm{SS}_{\mathrm{i}}=\text { Shift-Share } \\
& \mathrm{TR}_{\mathrm{i}}=\text { Transit Region share } \\
& \mathrm{SM}_{\mathrm{i}}=\text { Sector Mix } \\
& \mathrm{FGT}_{\mathrm{i}}=\text { FGT Station Area shift }
\end{aligned}
$$

The Transit Region (TR) share measures by how much total activity in a FGT station area changed because of change in the TR economy during the period of analysis. If TR population grew by $10 \%$ during the analysis period, then population in the FGT station area would have also grown by $10 \%$. The Sector Mix (SM) identifies fast growing or slow growing features in a FGT station area based on the TR growth rates for the individual economic sectors. For instance, an FGT station area with an above-average share of the TR's households by age would have grown faster than an FGT station area with a high share of households in certain age groups. The FGT station area shift, also called the "competitive effect", is the most relevant component. It identifies a FGT station area's leading and lagging features. In particular, the competitive effect compares a FGT station area's growth rate in a given household age group with the growth rate for that same age group at the TR level. A leading sector is one where that sector's FGT station area growth rate for that age group is greater than its TR growth rate. A lagging sector is one 
where the sector's FGT station area growth rate for that age group is less than its TR growth rate. 10

The equations for each component of the shift-share analysis are:

$$
\begin{gathered}
\mathrm{TR}=\left({ }_{\mathrm{i}} \text { FGT Station Area }{ }^{\mathrm{t}-1} \mathrm{x} \mathrm{TR}^{\mathrm{t}} / \mathrm{TR}^{\mathrm{t}-1}\right) \\
\mathrm{SM}=\left[\left({ }_{\mathrm{i}} \mathrm{FGT} \text { Station Area }{ }^{\mathrm{t}-1} \mathrm{x}_{\mathrm{i}} \mathrm{TR}^{\mathrm{t}} /{ }_{\mathrm{i}} \mathrm{TR}^{\mathrm{t}-1}\right)-\mathrm{TR}\right] \\
\text { FGT }=\left[_{\mathrm{i}} \text { FGT Station Area }{ }^{\mathrm{t}-1} \mathrm{x}\left({ }_{\mathrm{i}} \text { FGT Station Area } /{ }_{\mathrm{i}} \text { FGT Station Area }{ }^{\mathrm{t}-1}-{ }_{\mathrm{i}} \mathrm{TR}^{\mathrm{t}} / \mathrm{TR}^{\mathrm{t}-1}\right)\right]
\end{gathered}
$$

Where:

${ }_{\mathrm{i}}$ FGT Station Area ${ }^{\mathrm{t}-1}=$ number of jobs in the FGT Station Area sector (i) at the beginning of the analysis period (t-1)

${ }_{i}$ FGT Station Area ${ }^{\mathrm{t}}=$ number of jobs in the FGT Station Area in sector (i) at the end of the analysis period $(\mathrm{t})$

$\mathrm{TR}^{\mathrm{t}-1}=$ total number of jobs in the Transit Region at the beginning of the analysis period $(\mathrm{t}-1)$

$\mathrm{TR}^{\mathrm{t}}=$ total number of jobs in the Transit Region at the end of the analysis period $(\mathrm{t})$

${ }_{\mathrm{i}} \mathrm{TR}^{\mathrm{t}-1}=$ number of jobs in the Transit Region in sector (i) at the beginning of the analysis period (t-1)

${ }_{\mathrm{i}}^{\mathrm{TR}} \mathrm{t}^{\mathrm{t}}=$ number of jobs in the Transit Region in sector (i) at the end of the analysis period (t)

While this formulation applies traditionally to jobs it can also apply to people based on race/ethnicity, households based on type and age, and housing tenure based on owning and renting. We apply these substitutions to the standard formula as shown below.

Our analysis considers only those systems operating during any part of each study period. For instance, as there were only three BRT systems in the US operating during most of the period 2000-2009, our analysis considered only those systems (see Table 3). This increased to 15

\footnotetext{
${ }^{10}$ We have adapted the Carnegie Mellon Center for Economic Development's description of how shiftshare works for our application.
} 
systems during the period 2010-2016. This achieves internal analytic consistency within time periods.

We note that shift-share is a method to associate outcomes to geographic areas, notably distance band proximity to FGT stations, but it is not a tool to derive cause-and-effect relationships.

Finally, we note that total land area within each distance band increases as distance from transit station increases, after accounting for land area assigned to closer distance bands. Notably:

$\begin{array}{lr}\text { Distance Band } & \text { Acres } \\ \text { Station to } 0.125 \text { mile } & 31 \\ >0.125 \text { to }<=0.250 \text { mile } & 94 \\ >0.250 \text { to }<=0.500 \text { mile } & 408 \\ >0.500 \text { to }<=0.750 \text { mile } & 723 \\ >0.750 \text { to }<=1.000 \text { mile } & 1,288\end{array}$

The implication is that there is vastly more land on which development can occur in the farthest distance bands than those closer in. Yet, as will be seen, the innermost distance bands usually command the largest share in the shift of people, households and housing. Even when they do not, the share is nonetheless more on a per-acre basis, often by a multiple.

\subsection{FINDINGS}

For brevity, we report findings for only FGT station area shares of shifts during the two time periods. We present findings for LRT, BRT, SCT and CRT station areas in tables 5.2 through 5.5, respectively. Each table has multiple sub-tables. For instance, $1^{\text {st }}, 2^{\text {nd }}$ and $3^{\text {rd }}$ Generation LRT systems (noted as sub-tables (a), (b) and (c), respectively). Each sub-table has two parts, the first reporting overall shifts in station area shares within each time period (i) and the second reporting the change in the shift of share of station area outcomes between those periods (ii) which will guide our discussion.

We discuss top-line findings for each type of system below.

\subsubsection{Light Rail Transit}

Tables 5.2a(i), b(i) and c(i) present station area shift share results for $1^{\text {st }}, 2^{\text {nd }}$ and $3^{\text {rd }}$ generation light rail systems for each of the periods (2000 to 2009 and 2010 to 2016) respectively, and the parts to each table (ii) report the difference in outcomes between the time periods.

\subsubsection{1 $\quad 1^{\text {st }}$ Generation LRT}

The $1^{\text {st }}$ Generation LRT systems were launched more than 20 years before the Great Recession. They include Buffalo, Cleveland, Pittsburgh, Portland, Sacramento, San Diego and San Jose. Notable trends include: 
- Most of the difference in the share of population shifts in the first (0.125-mile) distance band were among other than White Non-Latinos. Yet, White-Non-Latino dominated the change in share of population over the next two distance bands to 0.50 -mile. More interesting is that distance bands to 0.50-mile gained change in share suggesting regional population is shifting toward them.

- Households also shifted toward closer-in distance bands during the 2010-2016 period though households with children tended to shift away from the closest (0.125-mile) distance band. The largest change in the shift in the closest distance bands occurred among households with two or more adults but no children.

- Oddly, the youngest householder age group (under 25 years of age) lost share of regional change in all distance bands while the other age groups gained in most distance bands.

- Housing tenure clearly favored renters over owners in the innermost (0.125-mile) distance band though all distance bands to 1.00-mile gained share of regional change. 
Table 5.2a(i): $1^{\text {st }}$ Generation Light Rail Transit People and Housing Shift-Share Results for Transit Station Areas 2000-2009 and 2010-2016

\begin{tabular}{|c|c|c|c|c|c|c|c|c|c|c|}
\hline \multirow{2}{*}{$\begin{array}{l}\text { LRT 1st GENERATION } \\
\text { Demographic Metrics }\end{array}$} & \multicolumn{5}{|c|}{ Station Share 2000-2009 } & \multicolumn{5}{|c|}{ Station Share 2010-2016 } \\
\hline & 0.125 & 0.25 & 0.5 & 0.75 & 1 & 0.125 & 0.25 & 0.5 & 0.75 & 1 \\
\hline \multicolumn{11}{|l|}{ Minority } \\
\hline White Non-Latino & 250,272 & 130,144 & 151,712 & 139,873 & 139,491 & 250,284 & 150,834 & 158,769 & 139,491 & 159,386 \\
\hline All Other & 106,467 & 80,595 & 79,642 & 73,852 & 71,787 & 112,545 & 84,470 & 82,499 & 71,787 & 67,220 \\
\hline Total & 356,739 & 210,739 & 231,354 & 213,725 & 211,278 & 362,829 & 235,304 & 241,268 & 211,278 & 226,606 \\
\hline \multicolumn{11}{|l|}{ Household Type } \\
\hline 2+ Adult HH w/ Children & 26,229 & 13,668 & 16,229 & 17,460 & 16,384 & 23,221 & 16,818 & 42,106 & 35,353 & 46,123 \\
\hline Single Parent HH & 29,258 & 22,091 & 22,351 & 20,372 & 19,464 & 32,591 & 20,967 & 132,825 & 112,061 & 20,961 \\
\hline 2+ Adult HH no Children & 65,486 & 38,941 & 44,828 & 40,151 & 43,930 & 74,194 & 49,922 & 90,712 & 76,701 & 46,123 \\
\hline One Person HH & 61,876 & 40,907 & 38,485 & 32,001 & 32,764 & 62,198 & 42,287 & 19,223 & 16,384 & 32,990 \\
\hline Total & 182,876 & 115,634 & 121,920 & 110,011 & 112,562 & 192,225 & 130,087 & 51,687 & 43,930 & 117,404 \\
\hline \multicolumn{11}{|l|}{ Householder Age } \\
\hline HH under 25 & 11,309 & 7,329 & 6,602 & 17,460 & 16,384 & 8,764 & 6,981 & 5,337 & 4,659 & 4,551 \\
\hline HH 25-44 & 72,514 & 49,299 & 51,493 & 40,151 & 43,930 & 77,865 & 51,894 & 53,095 & 42,019 & 45,755 \\
\hline HН 45-64 & 64,829 & 38,759 & 43,140 & 20,372 & 19,464 & 67,223 & 46,205 & 47,452 & 41,573 & 42,713 \\
\hline HH 65 and Over & 34,206 & 20,067 & 20,651 & 32,001 & 32,764 & 38,021 & 24,986 & 26,920 & 23,789 & 24,364 \\
\hline Total & 182,879 & 115,475 & 121,907 & 110,011 & 112,562 & 191,894 & 130,087 & 132,825 & 112,061 & 117,404 \\
\hline \multicolumn{11}{|l|}{ Housing Tenure } \\
\hline Owner Occupied & 93,070 & 51,366 & 62,460 & 59,323 & 57,493 & 86,437 & 56,459 & 64,652 & 57,493 & 60,616 \\
\hline Renter Occupied & 89,817 & 64,111 & 59,445 & 50,017 & 54,561 & 105,450 & 73,621 & 68,166 & 54,561 & 56,781 \\
\hline Total & 182,894 & 115,484 & 121,912 & 109,347 & 112,061 & 191,894 & 130,087 & 132,825 & 112,061 & 117,404 \\
\hline
\end{tabular}


Table 5.2a(ii): $1^{\text {st }}$ Generation Light Rail Transit People and Housing Shift-Share Results for Transit Station Areas 2000-2009 and 2010-2016

\begin{tabular}{l|r|r|r|r|r}
\hline LRT 1st GENERATION & \multicolumn{5}{|c}{ Station Share Change 2000-2009 to 2010-2016 } \\
\hline Demographic Metrics & $\mathbf{0 . 1 2 5}$ & $\mathbf{0 . 2 5 0}$ & $\mathbf{0 . 5 0 0}$ & $\mathbf{0 . 7 5 0}$ & $\mathbf{1 . 0 0 0}$ \\
\hline Minority & & & & & \\
\hline White Non-Latino & 12 & 20,690 & 7,057 & $(382)$ & 19,895 \\
\hline All Other & 6,078 & 3,875 & 2,857 & $(2,065)$ & $(4,567)$ \\
\hline Total & 6,090 & 24,565 & 9,914 & $(2,447)$ & 15,328 \\
\hline Household Type & & & & & \\
\hline 2+ Adult HH w/ Children & $(3,008)$ & 3,150 & 25,877 & 17,893 & 29,739 \\
\hline Single Parent HH & 3,333 & $(1,124)$ & 110,474 & 91,689 & 1,497 \\
\hline 2+ Adult HH no Children & 8,708 & 10,981 & 45,884 & 36,550 & 2,193 \\
\hline One Person HH & 322 & 1,380 & $(19,262)$ & $(15,617)$ & 226 \\
\hline Total & 9,349 & 14,453 & $(70,233)$ & $(66,081)$ & 4,842 \\
\hline Householder Age & & & & & $(12,801)$ \\
\hline HH under 25 & $(2,545)$ & $(348)$ & $(1,265)$ & 1,868 & $1,833)$ \\
\hline HH 25-44 & 5,351 & 2,595 & 1,602 & 21,201 & 23,249 \\
\hline HH 45-64 & 2,394 & 7,446 & 4,312 & $(8,212)$ & $(8,400)$ \\
\hline HH 65 and Over & 3,815 & 4,919 & 6,269 & & 4,842 \\
\hline Total & 9,015 & 14,612 & 10,918 & 2,050 & \\
\hline Housing Tenure & & & & & \\
\hline Owner Occupied & $(6,633)$ & 5,093 & 2,192 & $(1,830)$ & 3,123 \\
\hline Renter Occupied & 15,633 & 9,510 & 8,721 & 4,544 & 2,220 \\
\hline Total & 9,000 & 14,603 & 10,913 & 2,714 & 5,343 \\
\hline
\end{tabular}




\subsubsection{2 $\quad 2^{\text {nd }}$ Generation LRT}

LRT systems launched in the decade before the Great Recession - the 1990s, are considered $2^{\text {nd }}$ Generation in our study, comprised of Dallas, Denver, Salt Lake City, and St. Louis. Notable trends seen in Table 5.2b(i) and (ii) include:

- In contrast to $1^{\text {st }}$ Generation LRT systems, shifts in the share of population favored White Non-Latino population while the total shift in the share of population favored distance bands up to 0.75-mile.

- Except for householders with children gaining share of region households shift in the first (0.125-mile) distance band, overall household type patterns were similar to the $1^{\text {st }}$ Generation findings.

- Likewise, except for the youngest householder age group gaining share of region households shift in the first (0.125-mile) distance band, overall householder age patterns were similar to the $1^{\text {st }}$ Generation findings.

- Again, except for the innermost (0.125-mile) distance band showing gains in home ownership relative to the region's change, housing tenure patterns were the same for the $1^{\text {st }}$ Generation.

\subsubsection{3 $\quad 3^{\text {rd }}$ Generation LRT}

To some extent, the $3^{\text {rd }}$ Generation LRT systems offer insights relating to a "natural experiment": that is, how are demographic patterns influenced by such an economic shock as the Great Recession with respect to LRT systems initiated just before and during the recession? These systems include Charlotte, Houston, Minneapolis-St. Paul, Norfolk, Phoenix and Seattle. In this case, the analysis substantially compares trends before these systems were launched or during their very earliest years, to outcomes since the Great Recession. Trends from Table 5.2c(i) and (ii) show that for the most part, while patterns of outcomes were less pronounced relative to $1^{\text {st }}$ and $2^{\text {nd }}$ Generation systems, trends were in the same direction, nonetheless.

\subsubsection{Overall LRT Trends}

Overall, we find a link between the presence of LRT systems and the attraction of people and households to them substantially within the first 0.50 mile and sometimes to 1.0 mile. With only the exception of the 2nd Generation, we find other than White Non-Latino persons to be attracted to locations nearest LRT stations. We also find, generally, that households without children and householders more than 25 but less than 65 years of age dominate the region's share of change in the distribution of households with respect to LRT station proximity. As we reported in Chapters 2 and 3, it may be that people and households are not only competing with firms and their workers for locations near LRT stations, but perhaps displacing them to other, though nearby, distance bands. 
Table 5.2b(i): ${ }^{\text {nd }}$ Generation Light Rail Transit People and Housing Shift-Share Results for Transit Station Areas 2000-2009 and 2010-2016

\begin{tabular}{|c|c|c|c|c|c|c|c|c|c|c|}
\hline \multirow{2}{*}{$\begin{array}{l}\text { LRT 2nd GENERATION } \\
\text { Demographic Metrics }\end{array}$} & \multicolumn{5}{|c|}{ Station Share 2000-2009 } & \multicolumn{5}{|c|}{ Station Share 2010-2016 } \\
\hline & 0.125 & 0.25 & 0.5 & 0.75 & 1 & 0.125 & 0.25 & 0.5 & 0.75 & 1 \\
\hline \multicolumn{11}{|l|}{ Minority } \\
\hline White Non-Latino & 129,510 & 91,849 & 112,103 & 123,504 & 140,283 & 162,305 & 88,872 & 121,710 & 140,283 & 108,162 \\
\hline All Other & 46,277 & 30,558 & 40,327 & 39,720 & 53,592 & 64,985 & 39,469 & 60,761 & 53,592 & 47,354 \\
\hline Total & 175,787 & 122,407 & 152,430 & 163,224 & 193,875 & 227,290 & 128,341 & 182,471 & 193,875 & 155,516 \\
\hline \multicolumn{11}{|l|}{ Household Type } \\
\hline 2+ Adult HH w/ Children & 13,553 & 9,038 & 9,640 & 13,114 & 13,363 & 15,733 & 6,919 & 28,635 & 30,774 & 3,441 \\
\hline Single Parent HH & 16,780 & 11,503 & 15,661 & 18,053 & 17,408 & 20,160 & 14,457 & 98,607 & 103,695 & 18,745 \\
\hline 2+ Adult HH no Children & 31,158 & 23,245 & 28,037 & 30,540 & 36,974 & 41,812 & 27,583 & 69,968 & 72,917 & 30,962 \\
\hline One Person HH & 34,770 & 25,337 & 31,413 & 31,035 & 35,939 & 42,885 & 24,682 & 10,253 & 13,363 & 25,738 \\
\hline Total & 96,277 & 69,139 & 84,767 & 92,758 & 103,695 & 120,601 & 73,652 & 34,336 & 36,974 & 85,405 \\
\hline \multicolumn{11}{|l|}{ Householder Age } \\
\hline HH under 25 & 7,995 & 4,721 & 6,309 & 13,114 & 13,363 & 9,041 & 4,235 & 6,944 & 5,769 & 3,441 \\
\hline HH 25-44 & 45,534 & 31,557 & 36,561 & 30,540 & 36,974 & 55,564 & 30,964 & 42,045 & 43,141 & 33,875 \\
\hline НH 45-64 & 29,535 & 21,986 & 27,279 & 18,053 & 17,408 & 37,455 & 25,393 & 31,746 & 36,713 & 30,918 \\
\hline HH 65 and Over & 13,189 & 10,846 & 14,604 & 31,035 & 35,939 & 18,529 & 13,048 & 17,860 & 18,060 & 17,159 \\
\hline Total & 96,265 & 69,122 & 84,765 & 92,758 & 103,695 & 120,601 & 73,652 & 98,607 & 103,695 & 85,405 \\
\hline \multicolumn{11}{|l|}{ Housing Tenure } \\
\hline Owner Occupied & 47,090 & 35,966 & 42,660 & 47,171 & 51,122 & 52,398 & 35,603 & 43,007 & 51,122 & 47,296 \\
\hline Renter Occupied & 49,168 & 33,163 & 42,106 & 45,588 & 52,569 & 68,199 & 38,045 & 55,596 & 52,569 & 38,105 \\
\hline Total & 96,262 & 69,133 & 84,770 & 92,763 & 103,695 & 120,601 & 73,652 & 98,607 & 103,695 & 85,405 \\
\hline
\end{tabular}


Table 5.2b(ii): $2^{\text {nd }}$ Generation Light Rail Transit People and Housing Shift-Share Results for Transit Station Areas 2000-2009 and 2010-2016

\begin{tabular}{|c|c|c|c|c|c|}
\hline \multirow{2}{*}{$\begin{array}{l}\text { LRT 2nd GENERATION } \\
\text { Demographic Metrics }\end{array}$} & \multicolumn{5}{|c|}{ Station Share Change 2000-2009 to 2010-2016 } \\
\hline & 0.125 & 0.250 & 0.500 & 0.750 & 1.000 \\
\hline \multicolumn{6}{|l|}{ Minority } \\
\hline White Non-Latino & 32,795 & $(2,977)$ & 9,607 & 16,779 & $(32,121)$ \\
\hline All Other & 18,708 & 8,911 & 20,434 & 13,872 & $(6,238)$ \\
\hline Total & 51,503 & 5,934 & 30,041 & 30,651 & $(38,359)$ \\
\hline \multicolumn{6}{|l|}{ Household Type } \\
\hline 2+ Adult HH w/ Children & 2,180 & $(2,119)$ & 18,995 & 17,660 & $(3,414)$ \\
\hline 2+ Adult HH no Children & 10,654 & 4,338 & 41,931 & 42,377 & $(6,012)$ \\
\hline One Person HH & 8,115 & $(655)$ & $(21,160)$ & $(17,672)$ & $(10,201)$ \\
\hline Total & 24,324 & 4,513 & $(50,431)$ & $(55,784)$ & $(18,290)$ \\
\hline \multicolumn{6}{|l|}{ Householder Age } \\
\hline HH under 25 & 1,046 & $(486)$ & 635 & $(7,345)$ & $(9,922)$ \\
\hline HH 25-44 & 10,030 & $(593)$ & 5,484 & 12,601 & $(3,099)$ \\
\hline HH 45-64 & 7,920 & 3,407 & 4,467 & 18,660 & 13,510 \\
\hline Total & 24,336 & 4,530 & 13,842 & 10,937 & $(18,290)$ \\
\hline \multicolumn{6}{|l|}{ Housing Tenure } \\
\hline Owner Occupied & 5,308 & $(363)$ & 347 & 3,951 & $(3,826)$ \\
\hline Renter Occupied & 19,031 & 4,882 & 13,490 & 6,981 & $(14,464)$ \\
\hline Total & 24,339 & 4,519 & 13,837 & 10,932 & $(18,290)$ \\
\hline
\end{tabular}


Table 5.2c(i): $3^{\text {rd }}$ Generation Light Rail Transit People and Housing Shift-Share Results for Transit Station Areas 2000-2009 and 2010-2016

\begin{tabular}{|c|c|c|c|c|c|c|c|c|c|c|}
\hline \multirow{2}{*}{$\begin{array}{l}\text { LRT 3rd GENERATION } \\
\text { Demographic Metrics }\end{array}$} & \multicolumn{5}{|c|}{ Station Share 2000-2009 } & \multicolumn{5}{|c|}{ Station Share 2010-2016 } \\
\hline & 0.125 & 0.25 & 0.5 & 0.75 & 1 & 0.125 & 0.25 & 0.5 & 0.75 & 1 \\
\hline \multicolumn{11}{|l|}{ Minority } \\
\hline White Non-Latino & 79,963 & 64,120 & 82,586 & 62,714 & 57,793 & 82,606 & 61,061 & 73,509 & 57,793 & 72,186 \\
\hline All Other & 52,214 & 31,097 & 41,462 & 31,635 & 39,310 & 75,111 & 38,883 & 47,861 & 39,310 & 37,608 \\
\hline Total & 132,177 & 95,217 & 124,048 & 94,349 & 97,103 & 157,717 & 99,944 & 121,370 & 97,103 & 109,794 \\
\hline \multicolumn{11}{|l|}{ Household Type } \\
\hline 2+ Adult HH w/ Children & 3,315 & 4,373 & 4,204 & 5,266 & 4,378 & 3,021 & 3,634 & 16,457 & 14,920 & 4,549 \\
\hline Single Parent HH & 12,757 & 7,228 & 12,922 & 10,368 & 10,536 & 16,262 & 7,576 & 70,726 & 53,363 & 12,526 \\
\hline 2+ Adult HH no Children & 23,578 & 19,004 & 24,080 & 18,533 & 20,912 & 29,178 & 21,314 & 54,263 & 38,437 & 23,740 \\
\hline One Person HH & 35,041 & 29,437 & 31,891 & 18,327 & 17,519 & 38,674 & 26,407 & 3,734 & 4,378 & 23,574 \\
\hline Total & 74,717 & 60,068 & 73,123 & 52,520 & 53,363 & 87,153 & 58,949 & 25,257 & 20,912 & 64,407 \\
\hline \multicolumn{11}{|l|}{ Householder Age } \\
\hline HH under 25 & 7,548 & 6,055 & 7,206 & 5,266 & 4,378 & 7,702 & 5,162 & 6,282 & 4,107 & 5,192 \\
\hline HH 25-44 & 34,804 & 28,381 & 33,396 & 18,533 & 20,912 & 39,975 & 27,582 & 31,127 & 22,630 & 27,916 \\
\hline HH 45-64 & 21,400 & 17,111 & 21,537 & 10,368 & 10,536 & 26,027 & 16,678 & 21,743 & 17,956 & 20,866 \\
\hline HH 65 and Over & 10,530 & 8,500 & 10,955 & 18,327 & 17,519 & 12,881 & 9,509 & 11,556 & 8,652 & 10,415 \\
\hline Total & 74,302 & 60,067 & 73,114 & 52,520 & 53,363 & 86,603 & 58,949 & 70,726 & 53,363 & 64,407 \\
\hline \multicolumn{11}{|l|}{ Housing Tenure } \\
\hline Owner Occupied & 25,459 & 21,071 & 27,824 & 25,876 & 24,143 & 26,958 & 19,068 & 24,451 & 24,143 & 27,306 \\
\hline Renter Occupied & 48,848 & 38,987 & 45,283 & 26,639 & 29,214 & 59,639 & 39,875 & 46,269 & 29,214 & 37,095 \\
\hline Total & 74,313 & 60,064 & 73,113 & 52,521 & 53,363 & 86,603 & 58,949 & 70,726 & 53,363 & 64,407 \\
\hline
\end{tabular}


Table 5.2c(ii): $3^{\text {rd }}$ Generation Light Rail Transit People and Housing Shift-Share Results for Transit Station Areas 2000-2009 and 2010-2016

\begin{tabular}{l|r|r|r|r|r}
\hline LRT 3rd GENERATION & \multicolumn{5}{|c}{ Station Share Change 2000-2009 to 2010-2016 } \\
\hline Demographic Metrics & $\mathbf{0 . 1 2 5}$ & $\mathbf{0 . 2 5 0}$ & $\mathbf{0 . 5 0 0}$ & $\mathbf{0 . 7 5 0}$ & $\mathbf{1 . 0 0 0}$ \\
\hline Minority & & & & & \\
\hline White Non-Latino & 2,643 & $(3,059)$ & $(9,077)$ & $(4,921)$ & 14,393 \\
\hline All Other & 22,897 & 7,786 & 6,399 & 7,675 & $(1,702)$ \\
\hline Total & 25,540 & 4,727 & $(2,678)$ & 2,754 & 12,691 \\
\hline Household Type & & & & & \\
\hline 2+ Adult HH w/ Children & $(294)$ & $(739)$ & 12,253 & 9,654 & 171 \\
\hline Single Parent HH & 3,505 & 348 & 57,804 & 42,995 & 1,990 \\
\hline 2+ Adult HH no Children & 5,600 & 2,310 & 30,183 & 19,904 & 2,828 \\
\hline One Person HH & 3,633 & $(3,030)$ & $(28,157)$ & $(13,949)$ & 6,055 \\
\hline Total & 12,436 & $(1,119)$ & $(47,866)$ & $(31,608)$ & 11,044 \\
\hline Householder Age & & & & & $(1,159)$ \\
\hline HH under 25 & 154 & $(893)$ & $(924)$ & 4,097 & 7,004 \\
\hline HH 25-44 & 5,171 & $(799)$ & $(2,269)$ & 7,588 & 10,330 \\
\hline HH 45-64 & 4,627 & $(433)$ & 206 & $(9,675)$ & $(7,104)$ \\
\hline HH 65 and Over & 2,351 & 1,009 & 601 & & 11,044 \\
\hline Total & 12,301 & $(1,118)$ & $(2,388)$ & & \\
\hline Housing Tenure & & & & $(1,343$ & \\
\hline Owner Occupied & 1,499 & $(2,003)$ & $(3,373)$ & $(1,733)$ & 3,163 \\
\hline Renter Occupied & 10,791 & 888 & 986 & 2,575 & 7,881 \\
\hline Total & 12,290 & $(1,115)$ & $(2,387)$ & 842 & 11,044 \\
\hline
\end{tabular}




\subsubsection{Bus Rapid Transit}

We report four BRT eras in Table 5.3a(i) and (ii) through Table 5.3d(i) and (ii).

\subsubsection{Pittsburg Pioneer}

We pay the Pittsburgh BRT system special homage with a separate analysis of its outcomes in Tables 5.3a(i) and (ii). In comparing trends between 2000-2009 and 20102016, we find that regional population and household share of change is positive but restricted mostly to the first (0.125-mile) and second (0.25-mile) distance bands. Within this these bands, White Non-Latino population dominated the regional share of change close to BRT stations, as did households other than those with 2 or more adults with children. In trends seen for LRT, younger households (though under 25 years of age) do not appear to be shifting to BRT station areas but all other householder age groups are. In a surprise, we also find that in the innermost (0.125-mile) distance band, regional shift in share of owners occurs. Though we find gains in most of the outcome measures beyond the 0.25-mile distance band, we suspect that the BRT link is limited mostly to the first (0.125-mile) distance band.

\subsubsection{Pre-Recession BRT Systems}

Table 5.3b(i) and (ii) report shift-share outcomes for BRT systems launched before the Great Recession, including Eugene-Springfield, Kansas City, Las Vegas and Stockton. Trends are decidedly different from those seen for Pittsburgh or systems launched during the Great Recession, though similar to systems initiated afterward. Notably, we find that for the most part there is no apparent link between BRT station proximity and increasing share of region change in people and households; indeed, the link if any appears to be negative, meaning that these BRT systems as whole do not appear to shift regional growth toward BRT stations.

\subsubsection{Great Recession BRT Systems}

Several BRT systems were launched during the Great Recession including Cleveland, Nashville, Phoenix,

Reno, Salt Lake City and Seattle. Table 5.3c(i) and (ii) report outcomes for these systems as a whole. For the most part, outcomes for these systems are similar to those for Pittsburgh in that there are positive shifts in the regional share of population and households within the innermost (0.125-mile) distance band.

\subsubsection{Post-Recession BRT Systems}

Table 5.3d(i) and (ii) report shift-share outcomes for BRT systems launched after Great Recession. These systems include San Antonio and San Diego. Overall, their performance is similar to the pre-recession BRT systems in that it appears that regional growth shifts away from BRT station areas. 


\subsubsection{Overall BRT Trends}

While mixed, we surmise that successful BRT systems tend to have narrow bands of influence on people and households, perhaps attracting them within just the innermost (0.125-mile) distance band. 
Table 5.3a(i): Pittsburgh Pioneer Bus Rapid Transit People and Housing Shift-Share Results for Transit Station Areas 2000-2009 and 2010-2016

\begin{tabular}{|c|c|c|c|c|c|c|c|c|c|c|}
\hline \multirow{2}{*}{$\begin{array}{l}\text { PIONEER- } \\
\text { PITTSBURGH } \\
\text { Demographic Metrics }\end{array}$} & \multicolumn{5}{|c|}{ Station Share 2000-2009 } & \multicolumn{5}{|c|}{ Station Share 2010-2016 } \\
\hline & 0.125 & 0.25 & 0.5 & 0.75 & 1 & 0.125 & 0.25 & 0.5 & 0.75 & 1 \\
\hline \multicolumn{11}{|l|}{ Minority } \\
\hline White Non-Latino & 72,850 & 56,939 & 46,191 & 36,512 & 40,296 & 81,935 & 48,021 & 53,216 & 40,296 & 43,298 \\
\hline All Other & 23,572 & 16,991 & 15,895 & 6,779 & 7,647 & 24,336 & 15,461 & 13,541 & 7,647 & 7,912 \\
\hline Total & 96,422 & 73,930 & 62,086 & 43,291 & 47,943 & 106,271 & 63,482 & 66,757 & 47,943 & 51,210 \\
\hline \multicolumn{11}{|l|}{ Household Type } \\
\hline 2+ Adult HH w/ Children & 4,440 & 3,886 & 1,865 & 2,458 & 2,490 & 2,695 & 3,453 & 7,357 & 5,276 & 0 \\
\hline Single Parent HH & 6,061 & 4,751 & 5,566 & 2,775 & 2,785 & 8,254 & 3,374 & 30,472 & 20,918 & 2,885 \\
\hline 2+ Adult HH no Children & 15,677 & 12,154 & 10,014 & 7,628 & 8,635 & 18,583 & 11,037 & 23,114 & 15,641 & 9,367 \\
\hline One Person HH & 19,623 & 12,458 & 9,084 & 6,822 & 7,005 & 19,766 & 11,120 & 3,368 & 2,490 & 7,639 \\
\hline Total & 45,805 & 33,253 & 26,533 & 19,687 & 20,918 & 49,301 & 28,987 & 12,197 & 8,635 & 22,734 \\
\hline \multicolumn{11}{|l|}{ Householder Age } \\
\hline HH under 25 & 2,838 & 1,852 & 1,459 & 2,458 & 2,490 & 2,388 & 1,688 & 1,327 & 892 & 946 \\
\hline HH 25-44 & 14,101 & 10,690 & 8,228 & 7,628 & 8,635 & 16,834 & 9,443 & 8,752 & 7,106 & 6,886 \\
\hline HH 45-64 & 17,315 & 12,248 & 10,413 & 2,775 & 2,785 & 17,642 & 9,940 & 11,783 & 8,098 & 8,439 \\
\hline HH 65 and Over & 11,525 & 8,457 & 6,421 & 6,822 & 7,005 & 12,434 & 7,913 & 8,607 & 4,819 & 6,460 \\
\hline Total & 45,782 & 33,250 & 26,524 & 19,687 & 20,918 & 49,301 & 28,987 & 30,472 & 20,918 & 22,734 \\
\hline \multicolumn{11}{|l|}{ Housing Tenure } \\
\hline Owner Occupied & 24,714 & 20,237 & 16,795 & 13,370 & 13,931 & 27,460 & 16,975 & 19,118 & 13,931 & 15,183 \\
\hline Renter Occupied & 21,084 & 13,017 & 9,741 & 6,316 & 6,986 & 21,840 & 12,011 & 11,353 & 6,986 & 7,550 \\
\hline Total & 45,799 & 33,255 & 26,537 & 19,687 & 20,918 & 49,301 & 28,987 & 30,472 & 20,918 & 22,734 \\
\hline
\end{tabular}


Table 5.3a(ii): Pittsburgh Pioneer Bus Rapid Transit People and Housing Shift-Share Results for Transit Station Areas 2000-2009 and 2010-2016

\begin{tabular}{l|r|r|r|r|r}
\hline PIONEER-PITTSBURGH & \multicolumn{5}{|c}{ Station Share Change 2000-2009 to 2010-2016 } \\
\hline Demographic Metrics & $\mathbf{0 . 1 2 5}$ & $\mathbf{0 . 2 5 0}$ & $\mathbf{0 . 5 0 0}$ & $\mathbf{0 . 7 5 0}$ & $\mathbf{1 . 0 0 0}$ \\
\hline Minority & & & & & \\
\hline White Non-Latino & 9,085 & $(8,918)$ & 7,025 & 3,784 & 3,002 \\
\hline All Other & 764 & $(1,530)$ & $(2,354)$ & 868 & 265 \\
\hline Total & 9,849 & $(10,448)$ & 4,671 & 4,652 & 3,267 \\
\hline Household Type & & & & & \\
\hline 2+ Adult HH w/ Children & $(1,745)$ & $(433)$ & 5,492 & 2,818 & $(2,490)$ \\
\hline Single Parent HH & 2,193 & $(1,377)$ & 24,906 & 18,143 & 100 \\
\hline 2+ Adult HH no Children & 2,906 & $(1,117)$ & 13,100 & 8,013 & 732 \\
\hline One Person HH & 143 & $(1,338)$ & $(5,716)$ & $(4,332)$ & 634 \\
\hline Total & 3,496 & $(4,266)$ & $(14,336)$ & $(11,052)$ & 1,816 \\
\hline Householder Age & & & & & $(1,566)$ \\
\hline HH under 25 & $(450)$ & $(164)$ & $(132)$ & $(522)$ & $(1,749)$ \\
\hline HH 25-44 & 2,733 & $(1,247)$ & 524 & $5,344)$ \\
\hline HH 45-64 & 327 & $(2,308)$ & 1,370 & 5,323 & 5,654 \\
\hline HH 65 and Over & 909 & $(544)$ & 2,186 & $(2,003)$ & $(545)$ \\
\hline Total & 3,519 & $(4,263)$ & 3,948 & 1,231 & 1,816 \\
\hline Housing Tenure & & & & & \\
\hline Owner Occupied & 2,746 & $(3,262)$ & 2,323 & 561 & 1,252 \\
\hline Renter Occupied & 756 & $(1,006)$ & 1,612 & 670 & 564 \\
\hline Total & 3,502 & $(4,268)$ & 3,935 & 1,231 & 1,816 \\
\hline
\end{tabular}


Table 5.3b(i): Pre-Recession Bus Rapid Transit People and Housing Shift-Share Results for Transit Station Areas 2000-2009 and 2010-2016

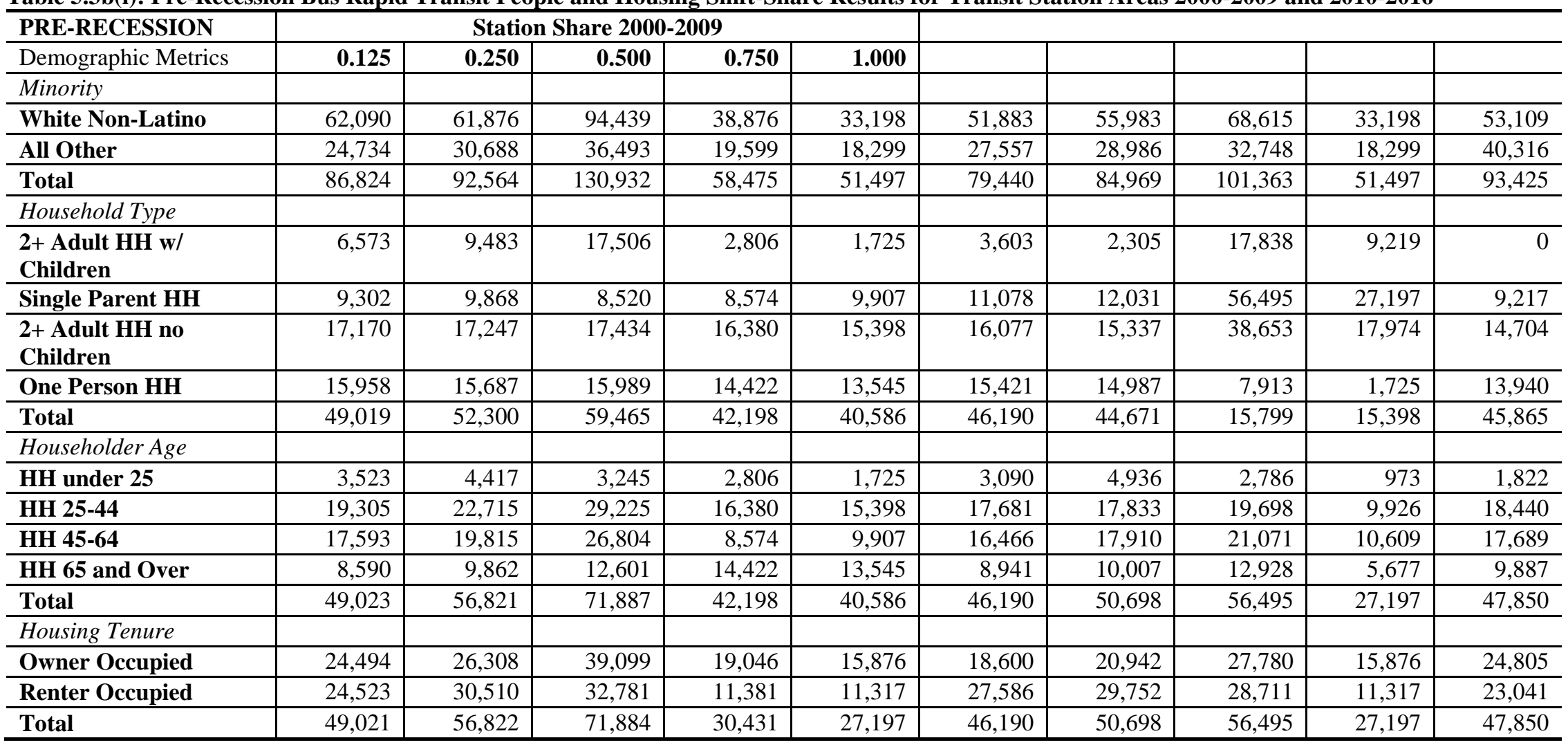


Table 5.3b(ii): Pre-Recession Bus Rapid Transit People and Housing Shift-Share Results for Transit Station Areas 2000-2009 and 2010-2016

\begin{tabular}{l|r|r|r|r|r}
\hline PRE-RECESSION & \multicolumn{5}{|c}{ Station Share Change 2000-2009 to 2010-2016 } \\
\hline Demographic Metrics & $\mathbf{0 . 1 2 5}$ & $\mathbf{0 . 2 5 0}$ & $\mathbf{0 . 5 0 0}$ & $\mathbf{0 . 7 5 0}$ & $\mathbf{1 . 0 0 0}$ \\
\hline Minority & & & & & \\
\hline White Non-Latino & $(10,207)$ & $(5,893)$ & $(25,824)$ & $(5,678)$ & 19,911 \\
\hline All Other & 2,823 & $(1,702)$ & $(3,745)$ & $(1,300)$ & 22,017 \\
\hline Total & $(7,384)$ & $(7,595)$ & $(29,569)$ & $(6,978)$ & 41,928 \\
\hline Household Type & & & & & \\
\hline 2+ Adult HH w/ Children & $(2,970)$ & $(7,178)$ & 332 & 6,413 & $(1,725)$ \\
\hline Single Parent HH & 1,776 & 2,163 & 47,975 & 18,623 & $(690)$ \\
\hline 2+ Adult HH no Children & $(1,093)$ & $(1,910)$ & 21,219 & 1,594 & $(694)$ \\
\hline One Person HH & $(537)$ & $(700)$ & $(8,076)$ & $(12,697)$ & 395 \\
\hline Total & $(2,829)$ & $(7,629)$ & $(43,666)$ & $(26,800)$ & 5,279 \\
\hline Householder Age & & & & & $(1,833)$ \\
\hline HH under 25 & $(433)$ & 519 & $(459)$ & $(4,45)$ & 97 \\
\hline HH 25-44 & $(1,624)$ & $(4,882)$ & $(9,527)$ & $(6,454)$ & 3,042 \\
\hline HH 45-64 & $(1,127)$ & $(1,905)$ & $(5,733)$ & 2,035 & 7,782 \\
\hline HH 65 and Over & 351 & 145 & 327 & $(8,745)$ & $(3,658)$ \\
\hline Total & $(2,833)$ & $(6,123)$ & $(15,392)$ & $(15,001)$ & 7,264 \\
\hline Housing Tenure & & & & & \\
\hline Owner Occupied & $(5,894)$ & $(5,366)$ & $(11,319)$ & $(3,170)$ & 8,929 \\
\hline Renter Occupied & 3,063 & $(758)$ & $(4,070)$ & $(64)$ & 11,724 \\
\hline Total & $(2,831)$ & $(6,124)$ & $(15,389)$ & $(3,234)$ & 20,653 \\
\hline
\end{tabular}


Table 5.3c(i): Great Recession Bus Rapid Transit People and Housing Shift-Share Results for Transit Station Areas 2000-2009 and 2010-2016

\begin{tabular}{|c|c|c|c|c|c|c|c|c|c|c|}
\hline \multirow{2}{*}{$\begin{array}{l}\text { GREAT RECESSION } \\
\text { Demographic Metrics }\end{array}$} & \multicolumn{5}{|c|}{ Station Share 2000-2009 } & \multicolumn{5}{|c|}{ Station Share 2010-2016 } \\
\hline & 0.125 & 0.25 & 0.5 & 0.75 & 1 & 0.125 & 0.25 & 0.5 & 0.75 & 1 \\
\hline \multicolumn{11}{|l|}{ Minority } \\
\hline White Non-Latino & 167,926 & 124,406 & 165,791 & 126,269 & 127,202 & 183,022 & 118,575 & 152,738 & 127,202 & 105,494 \\
\hline All Other & 54,381 & 44,244 & 50,940 & 42,365 & 47,735 & 71,381 & 48,844 & 61,813 & 47,735 & 41,053 \\
\hline Total & 222,307 & 168,650 & 216,731 & 168,634 & 174,937 & 254,403 & 167,419 & 214,551 & 174,937 & 146,547 \\
\hline \multicolumn{11}{|l|}{ Household Type } \\
\hline $\begin{array}{l}2+\text { Adult } \mathrm{HH} \text { w/ } \\
\text { Children }\end{array}$ & 11,209 & 10,043 & 13,647 & 12,157 & 12,571 & 13,562 & 8,221 & 30,458 & 26,043 & 0 \\
\hline Single Parent HH & 18,391 & 13,444 & 17,839 & 13,898 & 13,466 & 20,460 & 14,429 & 109,643 & 83,770 & 14,684 \\
\hline $\begin{array}{l}2+\text { Adult HH no } \\
\text { Children }\end{array}$ & 35,808 & 31,400 & 37,392 & 27,194 & 31,482 & 46,456 & 34,120 & 79,179 & 57,721 & 28,096 \\
\hline One Person HH & 45,473 & 38,473 & 40,713 & 24,682 & 26,299 & 48,526 & 34,027 & 11,896 & 12,571 & 23,712 \\
\hline Total & 110,904 & 93,383 & 109,614 & 77,954 & 83,836 & 129,022 & 90,815 & 39,494 & 31,482 & 74,918 \\
\hline \multicolumn{11}{|l|}{ Householder Age } \\
\hline HH under 25 & 8,347 & 7,076 & 8,621 & 12,157 & 12,571 & 9,516 & 6,029 & 7,979 & 4,825 & 3,817 \\
\hline HH 25-44 & 51,437 & 39,138 & 51,734 & 27,194 & 31,482 & 57,773 & 36,186 & 48,133 & 34,087 & 28,488 \\
\hline HH 45-64 & 35,253 & 30,680 & 36,102 & 13,898 & 13,466 & 41,467 & 30,239 & 36,263 & 30,023 & 27,128 \\
\hline HH 65 and Over & 15,829 & 16,181 & 16,284 & 24,682 & 26,299 & 20,173 & 17,283 & 17,250 & 14,817 & 14,860 \\
\hline Total & 110,886 & 93,095 & 112,761 & 77,954 & 83,836 & 128,947 & 89,755 & 109,643 & 83,770 & 74,311 \\
\hline \multicolumn{11}{|l|}{ Housing Tenure } \\
\hline Owner Occupied & 50,413 & 38,557 & 53,052 & 43,325 & 42,942 & 52,629 & 36,873 & 46,257 & 42,942 & 39,529 \\
\hline Renter Occupied & 60,468 & 54,515 & 59,704 & 36,086 & 40,822 & 76,312 & 52,876 & 63,380 & 40,822 & 34,776 \\
\hline Total & 110,887 & 93,078 & 112,762 & 79,417 & 83,770 & 128,947 & 89,755 & 109,643 & 83,770 & 74,311 \\
\hline
\end{tabular}


Table 5.3c(ii): Great Recession Bus Rapid Transit People and Housing Shift-Share Results for Transit Station Areas 2000-2009 and 2010-2016

\begin{tabular}{l|r|r|r|r|r}
\hline GREAT RECESSION & \multicolumn{3}{|c}{ Station Share Change 2000-2009 to 2010-2016 } \\
\hline Demographic Metrics & $\mathbf{0 . 1 2 5}$ & $\mathbf{0 . 2 5 0}$ & $\mathbf{0 . 5 0 0}$ & $\mathbf{0 . 7 5 0}$ & $\mathbf{1 . 0 0 0}$ \\
\hline Minority & & & & & \\
\hline White Non-Latino & 15,096 & $(5,831)$ & $(13,053)$ & 933 & $(21,708)$ \\
\hline All Other & 17,000 & 4,600 & 10,873 & 5,370 & $(6,682)$ \\
\hline Total & 32,096 & $(1,231)$ & $(2,180)$ & 6,303 & $(28,390)$ \\
\hline Household Type & & & & & \\
\hline 2+ Adult HH w/ Children & 2,353 & $(1,822)$ & 16,811 & 13,886 & $(12,571)$ \\
\hline Single Parent HH & 2,069 & 985 & 91,804 & 69,872 & 1,218 \\
\hline 2+ Adult HH no Children & 10,648 & 2,720 & 41,787 & 30,527 & $(3,386)$ \\
\hline One Person HH & 3,053 & $(4,446)$ & $(28,817)$ & $(12,111)$ & $(2,587)$ \\
\hline Total & 18,118 & $(2,568)$ & $(70,120)$ & $(46,472)$ & $(8,918)$ \\
\hline Householder Age & & & & & $(7,332)$ \\
\hline HH under 25 & 1,169 & $(1,047)$ & $(642)$ & 6,893 & $(2,994)$ \\
\hline HH 25-44 & 6,336 & $(2,952)$ & $(3,601)$ & 16,125 & 13,662 \\
\hline HH 45-64 & 6,214 & $(441)$ & 161 & $(9,865)$ & $(11,439)$ \\
\hline HH 65 and Over & 4,344 & 1,102 & 966 & $(9,865)$ \\
\hline Total & 18,061 & $(3,340)$ & $(3,118)$ & 5,816 & $(9,525)$ \\
\hline Housing Tenure & & & & & \\
\hline Owner Occupied & 2,216 & $(1,684)$ & $(6,795)$ & $(383)$ & $(3,413)$ \\
\hline Renter Occupied & 15,844 & $(1,639)$ & 3,676 & 4,736 & $(6,046)$ \\
\hline Total & 18,060 & $(3,323)$ & $(3,119)$ & 4,353 & $(9,459)$ \\
\hline
\end{tabular}


Table 5.3d(i): Post-Recession Bus Rapid Transit People and Housing Shift-Share Results for Transit Station Areas 2000-2009 and 2010-2016

\begin{tabular}{|c|c|c|c|c|c|c|c|c|c|c|}
\hline \multirow{2}{*}{$\frac{\text { POST-RECESSION }}{\text { Demographic Metrics }}$} & \multicolumn{5}{|c|}{ Station Share 2000-2009 } & \multicolumn{5}{|c|}{ Station Share 2010-2016 } \\
\hline & 0.125 & 0.25 & 0.5 & 0.75 & 1 & 0.125 & 0.25 & 0.5 & 0.75 & 1 \\
\hline \multicolumn{11}{|l|}{ Minority } \\
\hline White Non-Latino & 64,465 & 42,787 & 34,563 & 35,899 & 34,081 & 50,234 & 41,548 & 39,557 & 34,081 & 30,956 \\
\hline All Other & 27,491 & 13,499 & 19,861 & 12,656 & 12,665 & 29,456 & 18,533 & 25,853 & 12,665 & 12,647 \\
\hline Total & 91,956 & 56,286 & 54,424 & 48,555 & 46,746 & 79,690 & 60,081 & 65,410 & 46,746 & 43,603 \\
\hline \multicolumn{11}{|l|}{ Household Type } \\
\hline 2+ Adult HH w/ Children & 6,156 & 2,394 & 3,960 & 3,786 & 4,186 & 5,550 & 3,358 & 11,732 & 8,569 & 0 \\
\hline Single Parent $\mathrm{HH}$ & 6,962 & 4,963 & 5,041 & 4,088 & 4,380 & 7,949 & 5,301 & 39,513 & 31,482 & 4,327 \\
\hline 2+ Adult HH no Children & 19,997 & 13,374 & 12,024 & 12,150 & 12,668 & 19,900 & 14,959 & 27,778 & 22,910 & 11,710 \\
\hline One Person HH & 21,692 & 15,565 & 11,360 & 11,652 & 10,239 & 20,714 & 13,597 & 4,821 & 4,186 & 7,974 \\
\hline Total & 54,819 & 36,308 & 32,397 & 31,688 & 31,482 & 54,122 & 37,224 & 16,086 & 12,668 & 28,079 \\
\hline \multicolumn{11}{|l|}{ Householder Age } \\
\hline HH under 25 & 5,134 & 2,494 & 2,665 & 3,786 & 4,186 & 3,707 & 3,053 & 2,952 & 1,195 & 1,305 \\
\hline HH 25-44 & 25,764 & 16,413 & 14,712 & 12,150 & 12,668 & 26,443 & 15,255 & 16,430 & 13,472 & 11,645 \\
\hline НH 45-64 & 16,897 & 11,085 & 10,016 & 4,088 & 4,380 & 16,444 & 11,955 & 13,664 & 10,537 & 9,602 \\
\hline HH 65 and Over & 7,014 & 6,309 & 4,995 & 11,652 & 10,239 & 7,519 & 6,700 & 6,458 & 6,269 & 5,518 \\
\hline Total & 54,818 & 36,310 & 32,397 & 31,688 & 31,482 & 54,122 & 36,972 & 39,513 & 31,482 & 28,079 \\
\hline \multicolumn{11}{|l|}{ Housing Tenure } \\
\hline Owner Occupied & 20,695 & 14,672 & 14,050 & 15,855 & 14,864 & 15,607 & 12,657 & 16,672 & 14,864 & 13,863 \\
\hline Renter Occupied & 34,113 & 21,635 & 18,348 & 15,829 & 16,615 & 38,512 & 24,312 & 22,838 & 16,615 & 14,213 \\
\hline Total & 54,811 & 36,310 & 32,401 & 31,687 & 31,482 & 54,122 & 36,972 & 39,513 & 31,482 & 28,079 \\
\hline
\end{tabular}


Table 5.3d(ii): Post-Recession Bus Rapid Transit People and Housing Shift-Share Results for Transit Station Areas 2000-2009 and 2010-2016

\begin{tabular}{|c|c|c|c|c|c|}
\hline \multirow{2}{*}{$\frac{\text { POST-RECESSION }}{\text { Demographic Metrics }}$} & \multicolumn{5}{|c|}{ Station Share Change $2000-2009$ to $2010-2016$} \\
\hline & 0.125 & 0.250 & 0.500 & 0.750 & 1.000 \\
\hline \multicolumn{6}{|l|}{ Minority } \\
\hline White Non-Latino & $(14,231)$ & $(1,239)$ & 4,994 & $(1,818)$ & $(3,125)$ \\
\hline All Other & 1,965 & 5,034 & 5,992 & 9 & (18) \\
\hline Total & $(12,266)$ & 3,795 & 10,986 & $(1,809)$ & $(3,143)$ \\
\hline \multicolumn{6}{|l|}{ Household Type } \\
\hline 2+ Adult HH w/ Children & (606) & 964 & 7,772 & 4,783 & $(4,186)$ \\
\hline Single Parent HH & 987 & 338 & 34,472 & 27,394 & (53) \\
\hline 2+ Adult HH no Children & $(97)$ & 1,585 & 15,754 & 10,760 & $(958)$ \\
\hline One Person HH & (978) & $(1,968)$ & $(6,539)$ & $(7,466)$ & $(2,265)$ \\
\hline Total & $(697)$ & 916 & $(16,311)$ & $(19,020)$ & $(3,403)$ \\
\hline \multicolumn{6}{|l|}{ Householder Age } \\
\hline HH under 25 & $(1,427)$ & 559 & 287 & $(2,591)$ & $(2,881)$ \\
\hline HH 25-44 & 679 & $(1,158)$ & 1,718 & 1,322 & $(1,023)$ \\
\hline HH 45-64 & $(453)$ & 870 & 3,648 & 6,449 & 5,222 \\
\hline HH 65 and Over & 505 & 391 & 1,463 & $(5,383)$ & $(4,721)$ \\
\hline Total & $(696)$ & 662 & 7,116 & $(206)$ & $(3,403)$ \\
\hline \multicolumn{6}{|l|}{ Housing Tenure } \\
\hline Owner Occupied & $(5,088)$ & $(2,015)$ & 2,622 & (991) & $(1,001)$ \\
\hline Renter Occupied & 4,399 & 2,677 & 4,490 & 786 & $(2,402)$ \\
\hline Total & $(689)$ & 662 & 7,112 & (205) & $(3,403)$ \\
\hline
\end{tabular}




\subsubsection{Streetcar Transit}

Outcomes for SCT systems by era are shown in Tables 5.4a(i) and (ii) and 5.4b(i) and (ii). There are two SCT eras: those systems launched in the early 2000s and then a decade later, those launched several years after the Great Recession.

\subsubsection{1 $\quad 1^{\text {st }}$ Generation SCT Systems}

Shortly after Portland initiated its pioneering system in 2001 several others followed, including Little Rock, Seattle, Tacoma and Tampa. While Little Rock and Tampa are geared toward serving tourists, our market rent analysis indicates that commercial real estate markets respond to their proximity to SCT stops. We thus include them (and New Orleans) in our analysis.

For these systems, we find that people and households appear to be attracted to the first two distance bands, up to 0.25-mile away from SCT stations. Indeed, it is the second (0.25-mile) distance band that seems to perform best. But contrary to LRT and BRT systems, SCT systems appear to attract 2 or more adult households with children, though not single parent households. On the whole, however, the numerical shifts in shares of changes between the two study periods is modest being about an order of magnitude lower.

\subsubsection{2 $\quad 2^{\text {nd }}$ Generation SCT Systems}

After the Great Recession, several new SCT systems emerged. These may also provide a limited opportunity to assess natural experiment outcomes. These systems include Atlanta, Dallas, Salt Lake City and Tucson.

In contrast to $1^{\text {st }}$ Generation SCT systems, these systems are not apparently affective in gaining regional share of population near SCT stations, though there is a modest shift among households without children along with younger (under 25) and older (45 and above) householders.

\subsubsection{Overall SCT Trends}

We are surprised that SCT systems are not attracting a higher share of their transit region's population and household growth; it seems contrary to conventional wisdom. On the other hand, these systems tend to serve built-out downtown and near-downtown areas so while they may indeed add population and households, in the scheme of regional growth they do not account for a large share of that growth. 
Table 5.4a(i): $1^{\text {st }}$ Generation Streetcar Transit People and Housing Shift-Share Results for Transit Station Areas 2000-2009 and 2010-2016

\begin{tabular}{|c|c|c|c|c|c|c|c|c|c|c|}
\hline \multirow{2}{*}{$\begin{array}{l}\text { 1st GENERATION SCT } \\
\text { Demographic Metrics }\end{array}$} & \multicolumn{5}{|c|}{ Station Share 2000-2009 } & \multicolumn{5}{|c|}{ Station Share 2010-2016 } \\
\hline & 0.125 & 0.25 & 0.5 & 0.75 & 1 & 0.125 & 0.25 & 0.5 & 0.75 & 1 \\
\hline \multicolumn{11}{|l|}{ Minority } \\
\hline White Non-Latino & 27,656 & 28,842 & 20,676 & 20,065 & 22,025 & 28,016 & 35,518 & 22,310 & 20,394 & 28,000 \\
\hline All Other & 8,815 & 7,980 & 9,365 & 7,692 & 12,711 & 10,018 & 10,719 & 8,916 & 7,886 & 11,971 \\
\hline Total & 36,471 & 36,822 & 30,041 & 27,757 & 34,736 & 38,034 & 46,237 & 31,226 & 28,280 & 39,971 \\
\hline \multicolumn{11}{|l|}{ Household Type } \\
\hline 2+ Adult HH w/ Children & 458 & 160 & 1,694 & 3,344 & 1,501 & 880 & 843 & 2,741 & 3,803 & 0 \\
\hline Single Parent HH & 1,284 & 1,637 & 18,945 & 12,588 & 3,897 & 797 & 1,970 & 18,585 & 13,337 & 3,249 \\
\hline 2+ Adult HH no Children & 7,096 & 7,262 & 16,278 & 8,659 & 5,859 & 8,908 & 9,497 & 14,209 & 8,596 & 8,200 \\
\hline One Person HH & 15,578 & 17,248 & 803 & 1,478 & 7,016 & 14,316 & 16,643 & 1,582 & 1,404 & 7,761 \\
\hline Total & 24,668 & 26,467 & 5,914 & 4,556 & 18,291 & 24,916 & 29,004 & 6,749 & 5,184 & 21,384 \\
\hline \multicolumn{11}{|l|}{ Householder Age } \\
\hline HH under 25 & 2,712 & 2,576 & 1,578 & 512 & 1,120 & 2,321 & 2,718 & 1,159 & 340 & 1,233 \\
\hline HH 25-44 & 12,651 & 13,030 & 9,655 & 6,071 & 8,151 & 13,288 & 13,404 & 9,043 & 5,982 & 9,853 \\
\hline HH 45-64 & 6,561 & 7,475 & 5,158 & 4,720 & 5,571 & 6,315 & 7,764 & 5,467 & 4,978 & 6,295 \\
\hline HH 65 and Over & 2,728 & 3,318 & 2,538 & 1,267 & 2,606 & 2,977 & 4,950 & 2,901 & 2,022 & 3,244 \\
\hline Total & 24,667 & 26,414 & 18,944 & 12,585 & 17,463 & 24,916 & 28,851 & 18,585 & 13,337 & 20,640 \\
\hline \multicolumn{11}{|l|}{ Housing Tenure } \\
\hline Owner Occupied & 5,759 & 5,302 & 6,257 & 6,969 & 8,122 & 5,821 & 7,079 & 5,802 & 6,369 & 9,406 \\
\hline Renter Occupied & 18,905 & 21,104 & 12,681 & 5,611 & 9,335 & 19,090 & 21,767 & 12,778 & 6,963 & 11,229 \\
\hline Total & 24,669 & 26,411 & 18,943 & 12,585 & 17,462 & 24,916 & 28,851 & 18,585 & 13,337 & 20,640 \\
\hline
\end{tabular}


Table 5.4a(ii): $1^{\text {st }}$ Generation Streetcar Transit People and Housing Shift-Share Results for Transit Station Areas 2000-2009 and 2010-2016

\begin{tabular}{l|r|r|r|r|r}
\hline 1st GENERATION SCT & \multicolumn{4}{|c}{ Station Share Change 2000-2009 to 2010-2016 } \\
\hline Demographic Metrics & $\mathbf{0 . 1 2 5}$ & $\mathbf{0 . 2 5 0}$ & $\mathbf{0 . 5 0 0}$ & $\mathbf{0 . 7 5 0}$ & $\mathbf{1 . 0 0 0}$ \\
\hline Minority & & & & & \\
\hline White Non-Latino & 360 & 6,676 & 1,634 & 329 & 5,975 \\
\hline All Other & 1,203 & 2,739 & $(449)$ & 194 & $(740)$ \\
\hline Total & 1,563 & 9,415 & 1,185 & 523 & 5,235 \\
\hline Household Type & & & & & \\
\hline 2+ Adult HH w/ Children & 422 & 683 & 1,047 & 459 & $(1,501)$ \\
\hline Single Parent HH & $(487)$ & 333 & $(360)$ & 749 & $(648)$ \\
\hline 2+ Adult HH no Children & 1,812 & 2,235 & $(2,069)$ & $(63)$ & 2,341 \\
\hline One Person HH & $(1,262)$ & $(605)$ & 779 & $(74)$ & 745 \\
\hline Total & 248 & 2,537 & 835 & 628 & 3,093 \\
\hline Householder Age & & & & & \\
\hline HH under 25 & $(391)$ & 142 & $(419)$ & $(172)$ & 113 \\
\hline HH 25-44 & 637 & 374 & $(612)$ & $(89)$ & 1,702 \\
\hline HH 45-64 & $(246)$ & 289 & 309 & 258 & 724 \\
\hline HH 65 and Over & 249 & 1,632 & 363 & 755 & 638 \\
\hline Total & 249 & 2,437 & $(359)$ & 752 & 3,177 \\
\hline Housing Tenure & & & & & \\
\hline Owner Occupied & 62 & 1,777 & $(455)$ & $(600)$ & 1,284 \\
\hline Renter Occupied & 185 & 663 & 97 & 1,352 & 1,894 \\
\hline Total & 247 & 2,440 & $(358)$ & 752 & 3,178 \\
\hline
\end{tabular}


Table 5.4b(i): $2^{\text {nd }}$ Generation Streetcar Transit People and Housing Shift-Share Results for Transit Station Areas 2000-2009 and 2010-2016

\begin{tabular}{|c|c|c|c|c|c|c|c|c|c|c|}
\hline \multirow{2}{*}{$\begin{array}{l}\text { 2nd GENERATION SCT } \\
\text { Demographic Metrics }\end{array}$} & \multicolumn{5}{|c|}{ Station Share 2000-2009 } & \multicolumn{5}{|c|}{ Station Share 2010-2016 } \\
\hline & 0.125 & 0.25 & 0.5 & 0.75 & 1 & 0.125 & 0.25 & 0.5 & 0.75 & 1 \\
\hline \multicolumn{11}{|l|}{ Minority } \\
\hline White Non-Latino & 18,477 & 20,925 & 13,289 & 20,717 & 11,126 & 13,867 & 24,291 & 14,865 & 19,569 & 10,061 \\
\hline All Other & 12,563 & 6,939 & 6,086 & 7,315 & 11,690 & 7,626 & 8,349 & 6,313 & 6,813 & 9,215 \\
\hline Total & 31,040 & 27,864 & 19,375 & 28,032 & 22,816 & 21,493 & 32,640 & 21,178 & 26,382 & 19,276 \\
\hline \multicolumn{11}{|l|}{ Household Type } \\
\hline 2+ Adult HH w/ Children & 546 & 1,581 & 2,895 & 3,989 & 649 & 139 & 536 & 2,558 & 3,377 & 0 \\
\hline Single Parent $\mathrm{HH}$ & 1,800 & 1,330 & 11,744 & 16,862 & 2,873 & 1,378 & 2,052 & 10,601 & 16,542 & 2,230 \\
\hline 2+ Adult HH no Children & 4,185 & 5,172 & 8,845 & 12,869 & 3,609 & 5,093 & 6,691 & 8,039 & 13,161 & 3,748 \\
\hline One Person HH & 7,117 & 8,623 & 1,360 & 1,512 & 5,749 & 7,349 & 9,911 & 872 & 1,566 & 4,781 \\
\hline Total & 13,664 & 16,756 & 3,570 & 5,312 & 12,896 & 14,068 & 19,201 & 3,862 & 5,848 & 11,181 \\
\hline \multicolumn{11}{|l|}{ Householder Age } \\
\hline HH under 25 & 1,701 & 1,116 & 829 & 1,070 & 840 & 2,066 & 1,649 & 1,002 & 1,648 & 1,152 \\
\hline HH 25-44 & 7,646 & 8,367 & 6,311 & 8,208 & 6,773 & 7,383 & 9,270 & 5,064 & 6,898 & 3,793 \\
\hline HН 45-64 & 3,113 & 4,964 & 3,482 & 5,236 & 3,411 & 3,408 & 4,815 & 3,322 & 5,041 & 3,887 \\
\hline HH 65 and Over & 1,031 & 2,296 & 1,106 & 2,338 & 1,510 & 1,111 & 3,385 & 1,201 & 2,943 & 1,885 \\
\hline Total & 13,503 & 16,755 & 11,740 & 16,864 & 12,546 & 13,980 & 19,131 & 10,601 & 16,542 & 10,729 \\
\hline \multicolumn{11}{|l|}{ Housing Tenure } \\
\hline Owner Occupied & 3,184 & 6,712 & 4,646 & 7,695 & 4,433 & 3,609 & 6,980 & 4,184 & 6,766 & 3,881 \\
\hline Renter Occupied & 10,320 & 10,043 & 7,094 & 9,165 & 8,106 & 10,367 & 12,147 & 6,413 & 9,772 & 6,844 \\
\hline Total & 13,508 & 16,759 & 11,744 & 16,864 & 12,543 & 13,980 & 19,131 & 10,601 & 16,542 & 10,729 \\
\hline
\end{tabular}


Table 5.4b(ii): $2^{\text {nd }}$ Generation Streetcar Transit People and Housing Shift-Share Results for Transit Station Areas 2000-2009 and 2010-2016

\begin{tabular}{l|r|r|r|r|r}
\hline 2nd GENERATION SCT & \multicolumn{3}{|c}{ Station Share Change 2000-2009 to 2010-2016 } \\
\hline Demographic Metrics & $\mathbf{0 . 1 2 5}$ & $\mathbf{0 . 2 5 0}$ & $\mathbf{0 . 5 0 0}$ & $\mathbf{0 . 7 5 0}$ & $\mathbf{1 . 0 0 0}$ \\
\hline Minority & & & & & \\
\hline White Non-Latino & $(4,610)$ & 3,366 & 1,576 & $(1,148)$ & $(1,065)$ \\
\hline All Other & $(4,937)$ & 1,410 & 227 & $(502)$ & $(2,475)$ \\
\hline Total & $(9,547)$ & 4,776 & 1,803 & $(1,650)$ & $(3,540)$ \\
\hline Household Type & & & & & \\
\hline 2+ Adult HH w/ Children & $(407)$ & $(1,045)$ & $(337)$ & $(612)$ & $(649)$ \\
\hline Single Parent HH & $(422)$ & 722 & $(1,143)$ & $(320)$ & $(643)$ \\
\hline 2+ Adult HH no Children & 908 & 1,519 & $(806)$ & 292 & 139 \\
\hline One Person HH & 232 & 1,288 & $(488)$ & 54 & $(968)$ \\
\hline Total & 404 & 2,445 & 292 & 536 & $(1,715)$ \\
\hline Householder Age & & & & & \\
\hline HH under 25 & 365 & 533 & 173 & 578 & 312 \\
\hline HH 25-44 & $(263)$ & 903 & $(1,247)$ & $(1,310)$ & $(2,980)$ \\
\hline HH 45-64 & 295 & $(149)$ & $(160)$ & $(195)$ & 476 \\
\hline HH 65 and Over & 80 & 1,089 & 95 & 605 & 375 \\
\hline Total & 477 & 2,376 & $(1,139)$ & $(322)$ & $(1,817)$ \\
\hline Housing Tenure & & & & & \\
\hline Owner Occupied & 425 & 268 & $(462)$ & $(929)$ & $(552)$ \\
\hline Renter Occupied & 47 & 2,104 & $(681)$ & 607 & $(1,262)$ \\
\hline Total & 472 & 2,372 & $(1,143)$ & $(322)$ & $(1,814)$ \\
\hline
\end{tabular}




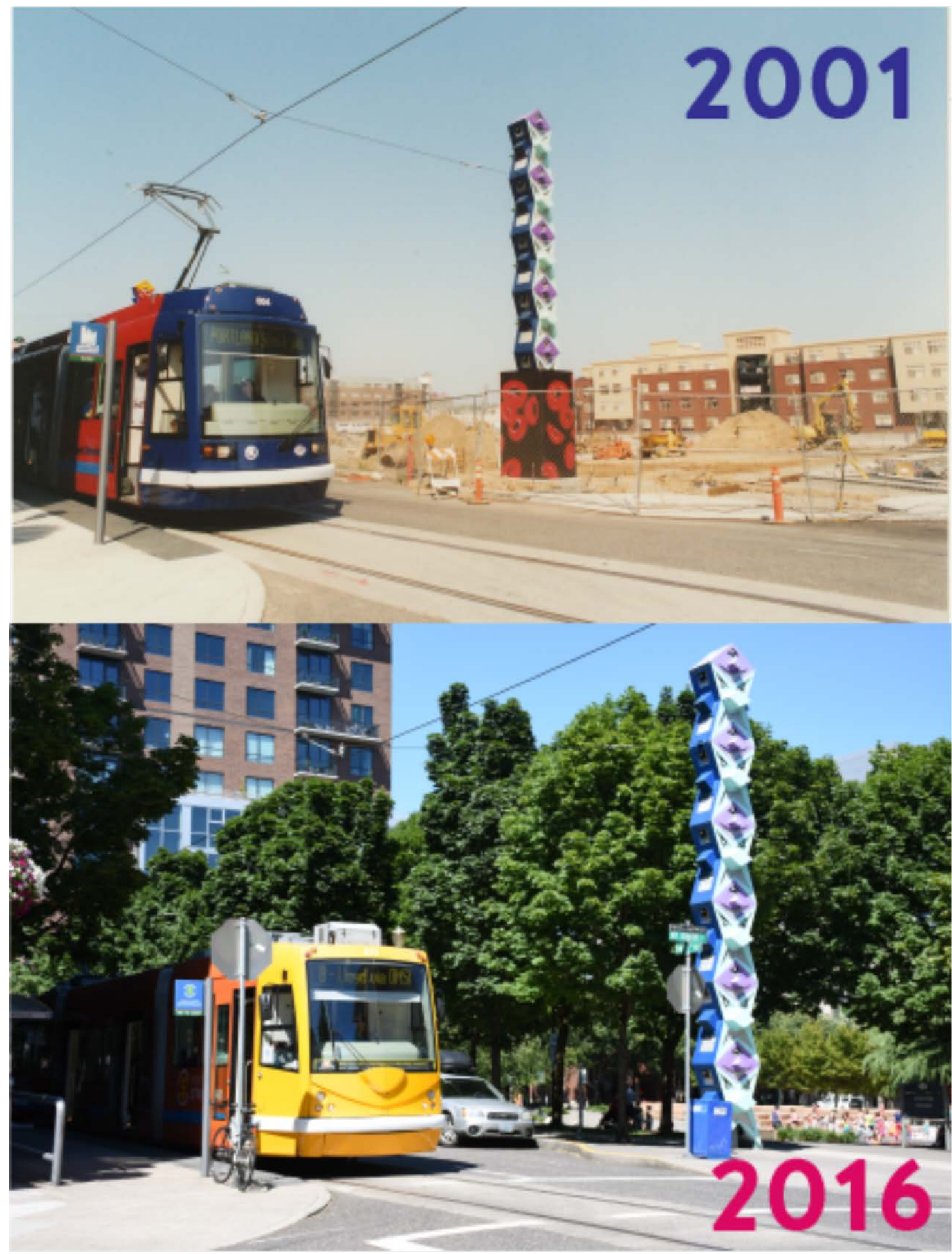

Figure 5.1: The Portland Streetcar is credited with facilitating new residential development since its inauguration in 2001.

Source: https://portlandstreetcar.org/about-us/media/photos. 


\subsubsection{Commuter Rail Transit}

Commuter Rail Transit results are reported in Tables 5.5a(i) and (ii) and 5.5b(i) and (ii). Two generations of CRT systems are considered-those commencing before the $21^{\text {st }}$ century and those launched in that century.

\subsubsection{1 $\quad 1^{\text {st }}$ Generation CRT Systems}

Pre-21 $1^{\text {st }}$ century CRT systems include Dallas-Fort Worth, Miami Tri-Rail, Minneapolis, San Diego, San Jose-Stockton, and Seattle-Tacoma. Similar to BRT and $1^{\text {st }}$ Generation SCT systems, we find that regional population and households appear to be attracted to the innermost (0.125-mile) distance band but not apparently to others nearby. Rental housing also dominates this distance band. We are surprised to find such a strong link to the innermost (0.125-mile) distance band as it seems to be conventional wisdom that people would not want to live near diesel trains and the freight traffic usually associated with then.

\subsubsection{2 $\quad 2^{\text {nd }}$ Generation CRT Systems}

$21^{\text {st }}$ Century CRT systems include Albuquerque, Austin, Nashville, Orlando, Portland and Salt Lake City. We find mostly similar outcomes among the $2^{\text {nd }}$ Generation CRT systems as we did for the $1^{\text {st }}$ Generation.

\subsubsection{Overall CRT Trends}

There are several lessons from this analysis. First of all, it appears that people and households can be attracted to areas near, even very near, CRT stations - which seems inconsistent with conventional wisdom. Second, as shows in Chapter 2, the apartment market values proximity to CRT rail stations perhaps up to two miles away from them. And third, given the underperformance of other than the innermost (0.125-mile) distance bands in attracting a larger regional share of people and households, we surmise that much can be done to meet latent residential market demand perhaps up to a mile or more away from CRT stations. 
Table 5.5a(i): $1^{\text {st }}$ Generation Commuter Rail Transit People and Housing Shift-Share Results for Transit Station Areas 2000-2009 and 2010-2016

\begin{tabular}{|c|c|c|c|c|c|c|c|c|c|c|}
\hline \multirow{2}{*}{$\begin{array}{l}\text { 1st GENERATION CRT } \\
\text { Demographic Metrics }\end{array}$} & \multicolumn{5}{|c|}{ Station Share 2000-2009 } & \multicolumn{5}{|c|}{ Station Share 2010-2016 } \\
\hline & 0.125 & 0.25 & 0.5 & 0.75 & 1 & 0.125 & 0.25 & 0.5 & 0.75 & 1 \\
\hline \multicolumn{11}{|l|}{ Minority } \\
\hline White Non-Latino & 108,872 & 127,990 & 131,438 & 196,014 & 170,188 & 113,822 & 103,722 & 127,232 & 170,188 & 169,344 \\
\hline All Other & 65,690 & 62,541 & 65,976 & 98,729 & 121,845 & 73,130 & 64,471 & 80,681 & 121,845 & 106,189 \\
\hline Total & 174,562 & 190,531 & 197,414 & 294,743 & 292,033 & 186,952 & 168,193 & 207,913 & 292,033 & 275,533 \\
\hline \multicolumn{11}{|l|}{ Household Type } \\
\hline 2+ Adult HH w/ Children & 12,355 & 15,217 & 13,603 & 24,775 & 23,005 & 13,451 & 11,881 & 33,187 & 47,465 & 21,137 \\
\hline Single Parent $\mathrm{HH}$ & 14,959 & 13,551 & 17,312 & 22,121 & 24,453 & 14,948 & 11,768 & 114,216 & 151,527 & 21,025 \\
\hline 2+ Adult HH no Children & 32,863 & 32,468 & 39,525 & 56,496 & 56,371 & 36,598 & 30,571 & 81,022 & 104,055 & 54,228 \\
\hline One Person HH & 32,711 & 32,688 & 36,921 & 51,910 & 47,677 & 31,121 & 29,004 & 13,404 & 23,005 & 41,398 \\
\hline Total & 92,916 & 93,952 & 107,389 & 155,330 & 151,527 & 96,139 & 83,388 & 43,082 & 56,371 & 137,809 \\
\hline \multicolumn{11}{|l|}{ Householder Age } \\
\hline HH under 25 & 4,135 & 5,803 & 6,357 & 24,775 & 23,005 & 3,704 & 4,464 & 6,206 & 6,603 & 5,418 \\
\hline HH 25-44 & 37,761 & 44,331 & 47,356 & 56,496 & 56,371 & 38,060 & 37,685 & 46,303 & 60,517 & 51,644 \\
\hline НH 45-64 & 32,763 & 30,890 & 35,725 & 22,121 & 24,453 & 35,891 & 29,283 & 39,987 & 54,911 & 53,670 \\
\hline HH 65 and Over & 18,189 & 12,906 & 17,923 & 51,910 & 47,677 & 18,430 & 11,935 & 21,699 & 29,475 & 27,056 \\
\hline Total & 92,869 & 93,951 & 107,382 & 155,330 & 151,527 & 96,106 & 83,388 & 114,216 & 151,527 & 137,809 \\
\hline \multicolumn{11}{|l|}{ Housing Tenure } \\
\hline Owner Occupied & 48,286 & 45,786 & 51,721 & 89,822 & 73,300 & 45,595 & 36,494 & 48,750 & 73,300 & 74,802 \\
\hline Renter Occupied & 44,596 & 48,148 & 55,663 & 65,501 & 78,220 & 50,504 & 46,887 & 65,459 & 78,220 & 63,000 \\
\hline Total & 92,889 & 93,941 & 107,391 & 155,330 & 151,527 & 96,106 & 83,388 & 114,216 & 151,527 & 137,809 \\
\hline
\end{tabular}


Table 5.5a(ii): $1^{\text {st }}$ Generation Commuter Rail Transit People and Housing Shift-Share Results for Transit Station Areas 2000-2009 and 2010-2016

\begin{tabular}{l|r|r|r|r|r}
\hline 1st GENERATION CRT & \multicolumn{3}{|c}{ Station Share Change 2000-2009 to 2010-2016 } \\
\hline Demographic Metrics & $\mathbf{0 . 1 2 5}$ & $\mathbf{0 . 2 5 0}$ & $\mathbf{0 . 5 0 0}$ & $\mathbf{0 . 7 5 0}$ & $\mathbf{1 . 0 0 0}$ \\
\hline Minority & & & & & \\
\hline White Non-Latino & 4,950 & $(24,268)$ & $(4,206)$ & $(25,826)$ & $(844)$ \\
\hline All Other & 7,440 & 1,930 & 14,705 & 23,116 & $(15,656)$ \\
\hline Total & 12,390 & $(22,338)$ & 10,499 & $(2,710)$ & $(16,500)$ \\
\hline Household Type & & & & & \\
\hline 2+ Adult HH w/ Children & 1,096 & $(3,336)$ & 19,584 & 22,690 & $(1,868)$ \\
\hline Single Parent HH & $(11)$ & $(1,783)$ & 96,904 & 129,406 & $(3,428)$ \\
\hline 2+ Adult HH no Children & 3,735 & $(1,897)$ & 41,497 & 47,559 & $(2,143)$ \\
\hline One Person HH & $(1,590)$ & $(3,684)$ & $(23,517)$ & $(28,905)$ & $(6,279)$ \\
\hline Total & 3,223 & $(10,564)$ & $(64,307)$ & $(98,959)$ & $(13,718)$ \\
\hline Householder Age & & & & & \\
\hline HH under 25 & $(431)$ & $(1,339)$ & $(151)$ & $(18,172)$ & $(17,587)$ \\
\hline HH 25-44 & 299 & $(6,646)$ & $(1,053)$ & 4,021 & $(4,727)$ \\
\hline HH 45-64 & 3,128 & $(1,607)$ & 4,262 & 32,790 & 29,217 \\
\hline HH 65 and Over & 241 & $(971)$ & 3,776 & $(22,435)$ & $(20,621)$ \\
\hline Total & 3,237 & $(10,563)$ & 6,834 & $(3,803)$ & $(13,718)$ \\
\hline Housing Tenure & & & & & \\
\hline Owner Occupied & $(2,691)$ & $(9,292)$ & $(2,971)$ & $(16,522)$ & 1,502 \\
\hline Renter Occupied & 5,908 & $(1,261)$ & 9,796 & 12,719 & $(15,220)$ \\
\hline Total & 3,217 & $(10,553)$ & 6,825 & $(3,803)$ & $(13,718)$ \\
\hline
\end{tabular}


Table 5.5b(i): $2^{\text {nd }}$ Generation Commuter Rail Transit People and Housing Shift-Share Results for Transit Station Areas 2000-2009 and 2010-2016

\begin{tabular}{|c|c|c|c|c|c|c|c|c|c|c|}
\hline \multirow{2}{*}{$\begin{array}{l}\text { 2nd GENERATION CRT } \\
\text { Demographic Metrics }\end{array}$} & \multicolumn{5}{|c|}{ Station Share 2000-2009 } & \multicolumn{5}{|c|}{ Station Share 2010-2016 } \\
\hline & 0.125 & 0.25 & 0.5 & 0.75 & 1 & 0.125 & 0.25 & 0.5 & 0.75 & 1 \\
\hline \multicolumn{11}{|l|}{ Minority } \\
\hline White Non-Latino & 48,035 & 39,639 & 53,459 & 50,047 & 54,985 & 50,715 & 35,951 & 56,885 & 54,985 & 81,948 \\
\hline All Other & 7,113 & 3,426 & 4,327 & 6,103 & 8,163 & 8,063 & 4,544 & 6,647 & 8,163 & 9,908 \\
\hline Total & 55,148 & 43,065 & 57,786 & 56,150 & 63,148 & 58,778 & 40,495 & 63,532 & 63,148 & 91,856 \\
\hline \multicolumn{11}{|l|}{ Household Type } \\
\hline 2+ Adult HH w/ Children & 28,368 & 31,975 & 45,429 & 44,744 & 47,343 & 31,163 & 28,038 & 51,253 & 49,631 & 62,922 \\
\hline Single Parent $\mathrm{HH}$ & 11,710 & 6,618 & 7,998 & 11,187 & 21,646 & 23,362 & 12,387 & 18,552 & 27,642 & 28,811 \\
\hline 2+ Adult HH no Children & 7,943 & 4,589 & 5,179 & 6,245 & 7,308 & 9,259 & 5,608 & 8,309 & 10,010 & 11,321 \\
\hline One Person HH & 41,843 & 41,545 & 56,037 & 59,497 & 73,027 & 58,423 & 44,597 & 64,385 & 70,777 & 98,792 \\
\hline Total & 14,550 & 6,159 & 6,425 & 6,091 & 8,676 & 15,885 & 7,204 & 2,628 & 3,037 & 16,961 \\
\hline \multicolumn{11}{|l|}{ Householder Age } \\
\hline HH under 25 & 1,091 & 809 & 1,223 & 1,377 & 1,494 & 1,383 & 1,262 & 1,315 & 1,546 & 1,961 \\
\hline HH 25-44 & 6,779 & 3,121 & 3,963 & 4,320 & 5,957 & 8,009 & 4,186 & 5,570 & 5,824 & 9,199 \\
\hline HН 45-64 & 7,255 & 2,492 & 3,173 & 2,995 & 3,126 & 6,167 & 3,246 & 3,232 & 3,904 & 6,437 \\
\hline HH 65 and Over & 9,632 & 7,262 & 6,087 & 11,266 & 10,882 & 10,977 & 8,001 & 9,593 & 9,988 & 14,855 \\
\hline Total & 59,459 & 49,081 & 65,705 & 73,679 & 80,950 & 70,067 & 49,528 & 79,201 & 80,753 & 111,950 \\
\hline \multicolumn{11}{|l|}{ Housing Tenure } \\
\hline Owner Occupied & 10,675 & 3,613 & 4,235 & 3,543 & 4,752 & 9,952 & 4,189 & 3,535 & 4,752 & 9,561 \\
\hline Renter Occupied & 3,868 & 1,926 & 2,003 & 2,209 & 3,726 & 5,931 & 3,013 & 3,391 & 3,726 & 7,399 \\
\hline Total & 14,545 & 5,541 & 6,239 & 5,753 & 8,479 & 15,885 & 7,204 & 6,927 & 8,479 & 16,961 \\
\hline
\end{tabular}


Table 5.5b(ii): $2^{\text {nd }}$ Generation Commuter Rail Transit People and Housing Shift-Share Results for Transit Station Areas 2000-2009 and 2010-2016

\begin{tabular}{|c|c|c|c|c|c|}
\hline \multirow{2}{*}{$\begin{array}{l}\text { 2nd GENERATION CRT } \\
\text { Demographic Metrics }\end{array}$} & \multicolumn{5}{|c|}{ Station Share Change 2000-2009 to 2010-2016 } \\
\hline & 0.125 & 0.250 & 0.500 & 0.750 & 1.000 \\
\hline \multicolumn{6}{|l|}{ Minority } \\
\hline White Non-Latino & 2,680 & $(3,688)$ & 3,426 & 4,938 & 26,963 \\
\hline All Other & 950 & 1,118 & 2,320 & 2,060 & 1,745 \\
\hline Total & 3,630 & $(2,570)$ & 5,746 & 6,998 & 28,708 \\
\hline \multicolumn{6}{|l|}{ Household Type } \\
\hline 2+ Adult HH w/ Children & 2,795 & $(3,937)$ & 5,824 & 4,887 & 15,579 \\
\hline Single Parent HH & 11,652 & 5,769 & 10,554 & 16,455 & 7,165 \\
\hline 2+ Adult HH no Children & 1,316 & 1,019 & 3,130 & 3,765 & 4,013 \\
\hline One Person HH & 16,580 & 3,052 & 8,348 & 11,280 & 25,765 \\
\hline Total & 1,335 & 1,045 & $(3,797)$ & $(3,054)$ & 8,285 \\
\hline \multicolumn{6}{|l|}{ Householder Age } \\
\hline HH under 25 & 292 & 453 & 92 & 169 & 467 \\
\hline HH 25-44 & 1,230 & 1,065 & 1,607 & 1,504 & 3,242 \\
\hline HH 45-64 & $(1,088)$ & 754 & 59 & 909 & 3,311 \\
\hline HH 65 and Over & 1,345 & 739 & 3,506 & $(1,278)$ & 3,973 \\
\hline Total & 10,608 & 447 & 13,496 & 7,074 & 31,000 \\
\hline \multicolumn{6}{|l|}{ Housing Tenure } \\
\hline Owner Occupied & (723) & 576 & (700) & 1,209 & 4,809 \\
\hline Renter Occupied & 2,063 & 1,087 & 1,388 & 1,517 & 3,673 \\
\hline Total & 1,340 & 1,663 & 688 & 2,726 & 8,482 \\
\hline
\end{tabular}




\subsection{IMPLICATIONS FOR TRANSIT AND LAND USE PLANNING}

That people and households are attracted to locations near FGT stations is shown in this chapter, but there are nuances:

- While there is a popular perception that young people/households would be attracted to areas near transit stations we find that this is not necessarily the case. In terms of the share of such households, transit stations do not perform well and often have a negative link with respect to station proximity.

- In contrast, it is the group of householders between the age of 25 and 44 that seem to be attracted more to FGT stations.

- Older households (ages 45 to 65 and 65 and older) seem especially attracted to areas near light rail stations, more so than younger ones.

- With few exceptions, households without children and, to a lesser extent, single parent households are attracted to locations near FGT stations.

- Areas near FGT stations tend to attract a higher share of their transit region's share rental demand, and a lower share of owner demand.

- While there is a positive link between changes in the share of regional population and household growth to about 0.50 mile from LRT stations-perhaps up to 1.00 mile-that link appears limited to just the innermost (0.125-mile) distance band from BRT, SCT and CRT stations. Yet we know from commercial rent analysis reported in Chapter 2 that the multifamily market pays a premium for proximity to these transit systems to 1.00 mile and in the case of SCT and CRT perhaps up to 2.00 miles away.

We surmise that there are opportunities to improve the ability of FGT stations to accommodate the regional demand for certain types of households who wish to live near them, though not necessarily very near them such as in the first 0.125 -mile. We came to the same supposition in Chapter 3.

Future research is needed to refine how people and households respond to FGT station proximity based on the kind or type of stations, the design of stations (see Chapter 8), and how market demand can be met.

In Chapter 6, we present research on the link between FGT station proximity and commuting mode choice. 
This page intentionally left blank. 


\section{REFERENCES}

Belzer, Dena, Robert Hickey, Wells Lawson, Shelley Poticha, and Jeff Wood (2007). The Case for Mixed-Income Transit-Oriented Development in the Denver Region. Oakland, CA: Center for Transit-Oriented Development.

Belzer, Dana, and Shelley Poticha (2009). Understanding Transit-Oriented Development: Lessons Learned 1999-2009. Fostering Equitable and Sustainable Transit-Orientated Development: 4-11.

Belzer, Dena, Sujata Srivastava, and Mason Austin (2011). Transit and Regional Economic Development. Oakland, CA: Center for Transit-Oriented Development.

Carnegie Mellon Center for Economic Development. Undated. Methods of regional analysis: Shift-share. Pittsburgh, PA: H. John Heinz School of Public Policy and Management, Carnegie Mellon University. Accessed from http://www.andrew.cmu.edu/user/jp87/URED/readings/Shift_Share.pdf.

Carrigan, Ailee, Robin King, Juan Miguel Velásquez, Nicolae Duduta and Matthew Raifman (2013). Social, Environmental and Economic Impacts of Bus Rapid Transit. Washington, DC: EMBARQ.

Center for Transit Oriented Development (2014). Trends in Transit-Oriented Development 2000-2010. Washington, DC: Federal Transit Administration.

Cervero, R., S. Murphy, C. Ferrell, N. Goguts, Y. Tsai, G. B. Arrington, J. Boroski, J. SmithHeimer, R. Golem, P. Peninger, E. Nakajima, E. Chui, R. Dunphy, M. Myers, S. McKay, and N. Witsenstein. (2004). Transit-Oriented Development in the United States: Experiences, Challenges, and Prospects. Washington, DC: Transportation Research Board.

Cervero, Robert, and Samuel Seskin (1995). An evaluation of the relationships between transit and urban form. TCRP Research Results Digest 7.

Cervero, Robert B. (2013). Linking urban transport and land use in developing countries. Journal of Transport and Land Use 6(1): 7-24.

Chapple, Karen and Anastasia Loukaitou-Sideris (2019). Transit-Oriented Displacement or Community Dividends? Understanding the Effects of Smarter Growth on Communities. Cambridge MA: MIT Press

Dawkins, Casey, and Ralph Buehler (2010). Promoting Affordable Housing near Public Transit: The Role of Planning. Policy Paper 3.

Dawkins, Casey, and Rolf Moeckel (2016). Transit-Induced Gentrification: Who Will Stay, and Who Will Go? Housing Policy Debate, 26:4-5, 801-818, DOI: 10.1080/10511482.2016.1138986 
Kolko, Jed (2011). Making the most of transit: Density, employment growth, and ridership around new stations. San Francisco, CA: Public Policy Institute of California.

Manson, Steven, Jonathan Schroeder, David Van Riper, and Steven Ruggles. IPUMS National Historical Geographic Information System: Version 13.0 [Database]. Minneapolis: University of Minnesota. 2018. http://doi.org/10.18128/D050.V13.0

Nelson, Arthur C. (2013). Reshaping Metropolitan America. Washington, DC: Island Press.

Nelson, Arthur C., Bruce Appleyard, Shyam Kannan, Reid Ewing, Matt Miller, Dejan Eskic (2013). Bus Rapid Transit and Economic Development: Case Study of the Eugene-Springfield BRT System. Journal of Public Transportation 16(3): 41-57. 


\subsection{THE LINK BETWEEN TRANSIT STATION PROXIMITY AND MODE CHOICE TO WORK, WORKING AT HOME, AND OWNING NO VEHICLES}

\subsection{OVERVIEW}

One theorized benefit of proximity to such fixed route transit (FRT) systems as light rail transit (LRT), bus rapid transit (BRT), streetcar transit (SCT), and commuter rail transit (CRT) is that residents will choose modes other than driving alone or carpooling to get to work. To the extent which FRT station areas themselves are also work destinations, people living near stations may also walk or bike to work. Moreover, proximity to transit enables those who work from home to access non-work destinations via transit or walking and biking if those destinations are near transit stations. However, there is no literature that establishes the link between (a) FRT station proximity and mode choice to work, or (b) an increase in share of people working at home to choose locations near transit stations. This chapter helps close this gap in research. It also provides insights for transit and land use planning.

\subsection{INTRODUCTION}

In this chapter, we explore:

The link between proximity to FRT stations and the commute mode choice to work;

The link between proximity to FRT stations and the share of workers working at home to choose residential locations near those stations; and

The link between FRT station proximity and household vehicle ownership.

In the first respect, literature suggests that people living near FRT systems (though not necessarily conventional bus systems) are somewhat more likely to use transit in their journey to work than people living farther away (see Ewing et al., 2017; Renne, 2009). Of course, there is a self-selection bias in that some people will to live near transit if they wish to use transit for commuting.

There is a nuance to this. If the FRT station itself is an employment destination, accessible via walking or biking, some will choose to live near transit stations but rarely actually use it because the station per se services as a micro-central business district (CBD), see Chapter 2). Thus, the share of people walking or biking to work to may increase because of transit station proximity even if the share using transit to work does not increase appreciably.

A separate issue that has not been addressed in literature is whether a higher share of people who work at home live near transit than elsewhere in the region. For these people, accessing transit for trips other than commuting to work improves their transport options. 
Who are these people who work at home but choose to be near transit? Among the possibilities are:

- Lower wage persons who are place-bound/home-bound because of parenting or caregiving. For instance, Chapter 5 notes that occasionally closer-in distance bands from transit stations are linked to higher shares in the regional shift of single parent households toward them.

- Those who are transportation handicapped and cannot own vehicles or drive themselves.

Which leads to whether transit accessibility is also linked to lower shares of vehicle ownership relative to the region as a whole; this is a substitution effect.

We apply economic base analysis to more than 40 light rail transit (LRT), bus rapid transit (BRT), streetcar transit (SCT) and commuter rail transit (CRT) systems operating in more than 30 metropolitan areas to estimate whether these outcomes are linked to FRT station proximity.

The analysis estimates outcomes with respect to one-eighth ( 0.125$)$, one-quarter ( 0.25$)$, one-half (0.50), three-quarters (0.75) and one (1.00) mile buffers of FRT stations from the end of the Great Recession well into economic recovery: 2010 to 2016.

Overall, we find positive shifts in the share of regional commuters who use transit, bike or walk to work with respect to FRT station proximity, and this link extends across our entire 1.00-mile study area. We also find that the propensity of working at home increases with respect to FRT station proximity.

This chapter begins with the research question, outlines the analytic framework and presents results for each type of transit system, and concludes with a summary. 


\subsection{RESEARCH QUESTION AND DESIGN}

The following research question guides research reported in this chapter:

Relative to the counties within which transit systems operate ("transit counties"), are there shifts in the regional share of:

Commuting mode choice with respect to FRT station proximity, particularly with respect to change in:

Driving alone and carpooling,

Transit, and

Walking and biking to work?

Workers working at home and transit station proximity?

Household vehicle ownership?

The research question lends itself to pre-post quasi-experimental design. Data, study periods, and analytic strategy are reviewed next.

\subsection{DATA}

For most of the analysis, we use decennial census data for 2000 and 2010, and American Community Survey (ACS) data for 2009 and 2016, compiled from the National Historical GIS (NHGIS) data files available online (Manson et al., 2018).

\subsection{STUDY PERIOD}

We evaluate shift in shares of demographic, housing, commuting and wage change over the period since the Great Recession (2008-2009), from 2010 through 2016.

This is the post-test period. Based on our theory, FRT station areas should capture a lower share of the shift of regional share in driving to work alone or carpooling, a higher share of regional shift in using transit, walking or biking to work, and a higher share of the regional shift in people working at home.

\subsection{FIXED ROUTE TRANSIT SYSTEMS STUDIED}

Table 6.1 shows the FRT systems we include in our analysis, organized by the period of time in which they commenced operations. We excluded systems in the largest metropolitan areas (such as New York City, Chicago, Los Angeles) or metropolitan areas with a complex web of public transit (such as Boston, Philadelphia, San Francisco-Oakland) because we wanted to estimate outcomes associated with individual systems independent of the influences of multiple systems. 
Table 6.1: Fixed Route Transit Systems Used in Analysis

\begin{tabular}{|c|c|c|c|c|c|c|c|}
\hline Light Rail Transit & Year & Bus Rapid Transit & Year & Streetcar Transit & Year & $\begin{array}{l}\text { Commuter Rail } \\
\text { Transit }\end{array}$ & Year \\
\hline Buffalo & 1984 & Cleveland & 2008 & Atlanta & 2014 & Albuquerque & 2006 \\
\hline Charlotte & 2007 & Eugene-Springfield & 2007 & Dallas & 2015 & Austin & 2010 \\
\hline Cleveland & 1980 & Kansas City & 2005 & Little Rock & 2004 & Dallas-Fort Worth & 1996 \\
\hline Dallas & 1996 & Las Vegas & 2004 & Portland & 2001 & Miami Tri-Rail & 1989 \\
\hline Denver & 1994 & Nashville & 2009 & Salt Lake City & 2013 & Minneapolis & 1997 \\
\hline Houston & 2004 & Phoenix & 2009 & Seattle & 2007 & Nashville & 2006 \\
\hline Minn.-St. Paul & 2004 & Pittsburgh & 1977 & Tacoma & 2003 & Orlando & 2014 \\
\hline Norfolk & 2011 & Reno & 2010 & Tampa & 2002 & Portland & 2009 \\
\hline Phoenix & 2008 & Salt Lake City & 2008 & Tucson & 2014 & Salt Lake City & 2008 \\
\hline Pittsburgh & 1984 & San Antonio & 2012 & & & San Diego & 1995 \\
\hline Portland & 1986 & San Diego & 2014 & & & San Jose-Stockton & 1998 \\
\hline Sacramento & 1987 & Seattle & 2010 & & & Seattle-Tacoma & 2000 \\
\hline Salt Lake City & 1999 & Stockton & 2007 & & & & \\
\hline San Diego & 1981 & & & & & & \\
\hline San Jose & 1987 & & & & & & \\
\hline Seattle & 2003 & & & & & & \\
\hline St. Louis & 1993 & & & & & & \\
\hline
\end{tabular}




\subsection{ANALYTIC APPROACH}

Given that change in employment share over time is our principal interest, we choose shift-share analysis as our analytic approach. This is similar to the approach we used to evaluate shifts in shares of jobs around bus rapid transit stations in the Eugene-Springfield (Oregon) metropolitan area. We adapt that analytic discussion to the present analysis (Nelson et al., 2013).

Shift-share analysis assigns the change or shift in the share or concentration of jobs with respect to the region, other economic sectors, and the local area. The "region" can be any level of geography and is often the nation or the state. In our case, it is where we want to see whether there are intrametropolitan shifts in the share of demographic, housing, mode choice, and jobs by wage category changes with respect to transit station proximity. Our region is the "Transit Region" meaning those counties within which FRT systems operated during the entire study period. The "local" area is often a city or county or even state, but it can be any geographic unit that is smaller than the region. Our local areas are the FRT station areas within 0.125 (oneeighth) mile, 0.250 (one quarter) mile, 0.500 (one half) mile, 0.750 (three quarters) mile, and 1.000 mile of the nearest FRT station. As shifts in the share of activities may vary because of changes in demographic, housing, mode choice, and job by wage mixes, there is also an "industry mix" adjustment that we call "sector mix". Using notations by the Carnegie Mellon Center for Economic Development (no date), the shift-share formula is:

$$
\mathrm{SS}_{\mathrm{i}}=\mathrm{TR}_{\mathrm{i}}+\mathrm{SM}_{\mathrm{i}}+\mathrm{FRT}_{\mathrm{i}}
$$

Where

$$
\begin{aligned}
& \mathrm{SS}_{\mathrm{i}}=\text { Shift-Share } \\
& \mathrm{TR}_{\mathrm{i}}=\text { Transit Region share } \\
& \mathrm{SM}_{\mathrm{i}}=\text { Sector Mix } \\
& \mathrm{FRT}_{\mathrm{i}}=\text { FRT Station Area shift }
\end{aligned}
$$

The Transit Region (TR) share measures by how much total activity in a FRT station area changed because of change in the TR economy during the period of analysis. If TR population grew by $10 \%$ during the analysis period, then population in the FRT station area would have also grown by $10 \%$. The Sector Mix (SM) identifies fast growing or slow growing features in a FRT station area based on the TR growth rates for the individual economic sectors. For instance, an FRT station area with an above-average share of the TR's households by age would have grown faster than an FRT station area with a high share of households in certain age groups. The FRT station area shift, also called the "competitive effect", is the most relevant component. It identifies a FRT station area's leading and lagging features. In particular, the competitive effect compares a FRT station area's growth rate in a given household age group with the growth rate for that same age group at the TR level. A leading sector is one where that sector's FRT station area growth rate for that age group is greater than its TR growth rate. A lagging sector is one 
where the sector's FRT station area growth rate for that age group is less than its TR growth rate. 11

The equations for each component of the shift-share analysis are:

$$
\begin{gathered}
\mathrm{TR}=\left({ }_{\mathrm{i}} \text { FRT Station Area }{ }^{\mathrm{t}-1} \mathrm{x} \mathrm{TR}^{\mathrm{t}} / \mathrm{TR}^{\mathrm{t}-1}\right) \\
\mathrm{SM}=\left[\left({ }_{\mathrm{i}} \text { FRT Station Area }{ }^{\mathrm{t}-1} \mathrm{x}_{\mathrm{i}} \mathrm{TR}^{\mathrm{t}} /{ }_{\mathrm{i}} \mathrm{TR}^{\mathrm{t}-1}\right)-\mathrm{TR}\right] \\
\text { FRT }=\left[{ }_{\mathrm{i}} \text { FRT Station Area }{ }^{\mathrm{t}-1} \mathrm{x}\left({ }_{\mathrm{i}} \text { FRT Station Area } /{ }_{\mathrm{i}} \text { FRT Station Area }{ }^{\mathrm{t}-1}-{ }_{\mathrm{i}} \mathrm{TR}^{\mathrm{t}} / \mathrm{TR}^{\mathrm{t}-1}\right)\right]
\end{gathered}
$$

Where:

${ }_{i}$ FRT Station Area ${ }^{\mathrm{t}-1}=$ number of jobs in the FRT Station Area sector (i) at the beginning of the analysis period (t-1)

${ }_{i}$ FRT Station Area ${ }^{\mathrm{t}}=$ number of jobs in the FRT Station Area in sector (i) at the end of the analysis period $(\mathrm{t})$

$\mathrm{TR}^{\mathrm{t}-1}=$ total number of jobs in the Transit Region at the beginning of the analysis period $(\mathrm{t}-1)$

$\mathrm{TR}^{\mathrm{t}}=$ total number of jobs in the Transit Region at the end of the analysis period ( $\mathrm{t}$ )

${ }_{\mathrm{i}} \mathrm{TR}^{\mathrm{t}-1}=$ number of jobs in the Transit Region in sector (i) at the beginning of the analysis period (t-1)

${ }_{\mathrm{i}} \mathrm{TR}^{\mathrm{t}}=$ number of jobs in the Transit Region in sector (i) at the end of the analysis period (t)

While this formulation applies traditionally to jobs it can also apply to worker mode choice in their journey to work, workers working at home, and household vehicles. We apply these substitutions to the standard formula as shown below.

Our analysis applies to all FRT systems operating at any point during the study period (see Table 6.1).

\footnotetext{
${ }^{11}$ We have adapted the Carnegie Mellon Center for Economic Development's description of how shift-
} share works for our application. 
We note that shift-share is a method to associate outcomes to geographic areas, notably distance band proximity to FRT stations, but it is not a tool to derive cause-and-effect relationships.

Finally, we note that total land area within each distance band increases as distance from transit station increases, after accounting for land area assigned to closer distance bands. Notably:

\section{Distance Band}

Station to 0.125 mile

$>0.125$ to $<=0.250$ mile

$>0.250$ to $<=0.500$ mile

$>0.500$ to $<=0.750$ mile

$>0.750$ to $<=1.000$ mile

\section{Acres}

31

94

408

723

1,288

The implication is that there is vastly more land on which development can occur in the farthest distance bands than those closer in. Yet, as will be seen, the innermost distance bands usually command the largest share in the shift of people, households and housing. Even when they do not, the share is nonetheless more on a per-acre basis, often by a multiple. 


\subsection{FINDINGS}

In the following four tables, 6.2 through 6.5, we report our findings for only FRT station area shares of shifts over the period 2010-2016. Figures 6.1 through 6.4 illustrate these trends. We discuss top-line findings for each type of system below.

For LRT, BRT and SCT systems, there appears to be a consistent pattern. The use of transit, walking or biking to work falls as the distance from transit station increases, though there is a modest increase between the 0.75- to 1.00-mile distance band. Likewise, the share of households without vehicles also decreases. The share of workers working at home is less pronounced, though it follows the same overall pattern.

Outcomes for CRT are quite different. Generally, the share of workers using transit-walkingbiking commuting, household vehicle ownership, and workers working at home fall over the first two distance bands, to about 0.25-mile, then increase to about the 0.75 -mile distance band before leveling off. We surmise the reason is that CRT service is not as frequent as the other modes.

In all cases, commuters who drove alone or carpooled clearly dominated the mode to work. Indeed, for LRT and BRT, the transit region share of commuters using these modes increased near those stations, but then so did the number of residents (see Chapter 5) and workers.

We conclude with implications for transit and land use planning.

\subsection{IMPLICATIONS FOR TRANSIT AND LAND USE PLANNING}

Although the driving alone/carpool commute remains the dominant mode, the change in share of commuters using other modes - especially with respect to transit station proximity - is not trivial and appears to be increasing modestly. As we noted in Chapters 2, 3 and 5, local efforts to meet apparently unmet market demand for jobs and housing beyond the innermost (0.125-mile) distance band to the 0.50 -mile, if not 1.00-mile distance bands, may increase regional share of workers engaging in modes other than driving alone/carpooling to work. 
Table 6.2: Shift in Share of Commuting Mode Choice, Workers Working at Home and Household Vehicle Ownership with Respect to Light Rail Transit Proximity, 2010-2016

\begin{tabular}{|c|c|c|c|c|c|}
\hline \multirow{2}{*}{$\begin{array}{l}\text { LRT STATION PROXIMITY } \\
\text { Commuting/Vehicle Metrics }\end{array}$} & \multicolumn{5}{|c|}{ Station Share 2010-2016 } \\
\hline & 0.125 & 0.25 & 0.5 & 0.75 & 1 \\
\hline \multicolumn{6}{|l|}{ Commuting } \\
\hline Drove Alone/Carpooled & 380,003 & 254,713 & 311,284 & 289,506 & 286,721 \\
\hline Transit & 42,668 & 27,489 & 27,022 & 21,700 & 22,908 \\
\hline Bike & 9,201 & 6,141 & 6,987 & 6,375 & 5,592 \\
\hline Walked & 34,144 & 19,946 & 17,004 & 10,121 & 10,859 \\
\hline Other & 4,327 & 3,289 & 3,864 & 2,517 & 3,295 \\
\hline Worked at Home & 27,276 & 16,958 & 18,648 & 17,813 & 19,287 \\
\hline Total Workers & 500,146 & 330,204 & 386,276 & 350,284 & 350,484 \\
\hline Transit-Bike-Walk-Home & 113,289 & 70,534 & 69,661 & 49,634 & 58,646 \\
\hline \multicolumn{6}{|l|}{ Vehicles } \\
\hline Vehicle(s) Present & 341,379 & 224,923 & 266,333 & 241,788 & 239,108 \\
\hline No Vehicles & 57,702 & 37,748 & 35,808 & 27,314 & 28,091 \\
\hline Total Households & 399,098 & 262,688 & 302,158 & 269,119 & 267,216 \\
\hline
\end{tabular}




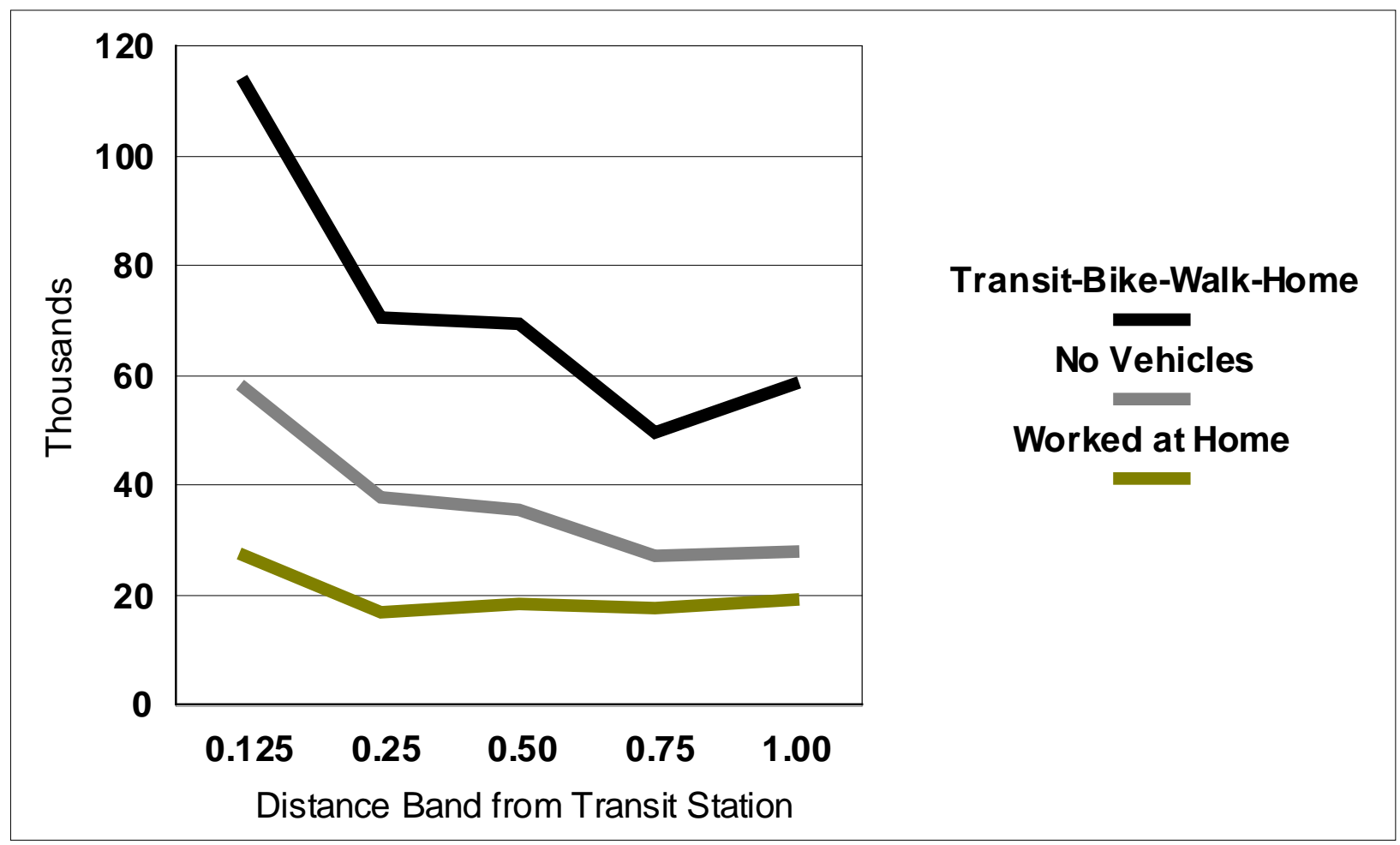

Figure 6.1: Share of Transit Region Change in Selected Commuting Mode Choice, Households without Vehicles and Workers Working at Home by Distance Band from Light Rail Stations, 2010-2016 
Table 6.3: Shift in Share of Commuting Mode Choice, Workers Working at Home and Household Vehicle Ownership with Respect to Bus Rapid Transit Proximity, 2010-2016

\begin{tabular}{l|r|r|r|r|r}
\hline BRT STATION PROXIMITY & \multicolumn{7}{c}{ Station Share $\mathbf{2 0 1 0 - 2 0 1 6}$} \\
\hline Commuting/Vehicle Metrics & $\mathbf{0 . 1 2 5}$ & $\mathbf{0 . 2 5}$ & $\mathbf{0 . 5}$ & \multicolumn{1}{c}{$\mathbf{0 . 7 5}$} & $\mathbf{1}$ \\
\hline Commuting & & & & & \\
\hline Drove Alone/Carpooled & 262,028 & 192,674 & 240,067 & 170,090 & 188,207 \\
\hline Transit & 32,650 & 22,328 & 23,828 & 17,743 & 15,448 \\
\hline Bike & 3,855 & 3,369 & 4,412 & 3,653 & 2,545 \\
\hline Walked & 21,442 & 14,368 & 13,727 & 7,147 & 5,468 \\
\hline Other & 2,981 & 2,806 & 2,613 & 2,100 & 2,471 \\
\hline Worked at Home & 15,374 & 12,427 & 14,384 & 10,272 & 9,929 \\
\hline Total Workers & 339,937 & 249,086 & 300,436 & 211,326 & 225,216 \\
\hline Transit-Bike-Walk-Home & 73,321 & 52,492 & 56,351 & 35,162 & 33,390 \\
\hline Vehicles & & & & & \\
\hline Vehicle(s) Present & 236,455 & 173,857 & 205,976 & 145,330 & 156,257 \\
\hline No Vehicles & 42,091 & 32,541 & 30,133 & 18,023 & 16,703 \\
\hline Total Households & 278,560 & 206,412 & 236,123 & 163,367 & 172,974 \\
\hline
\end{tabular}




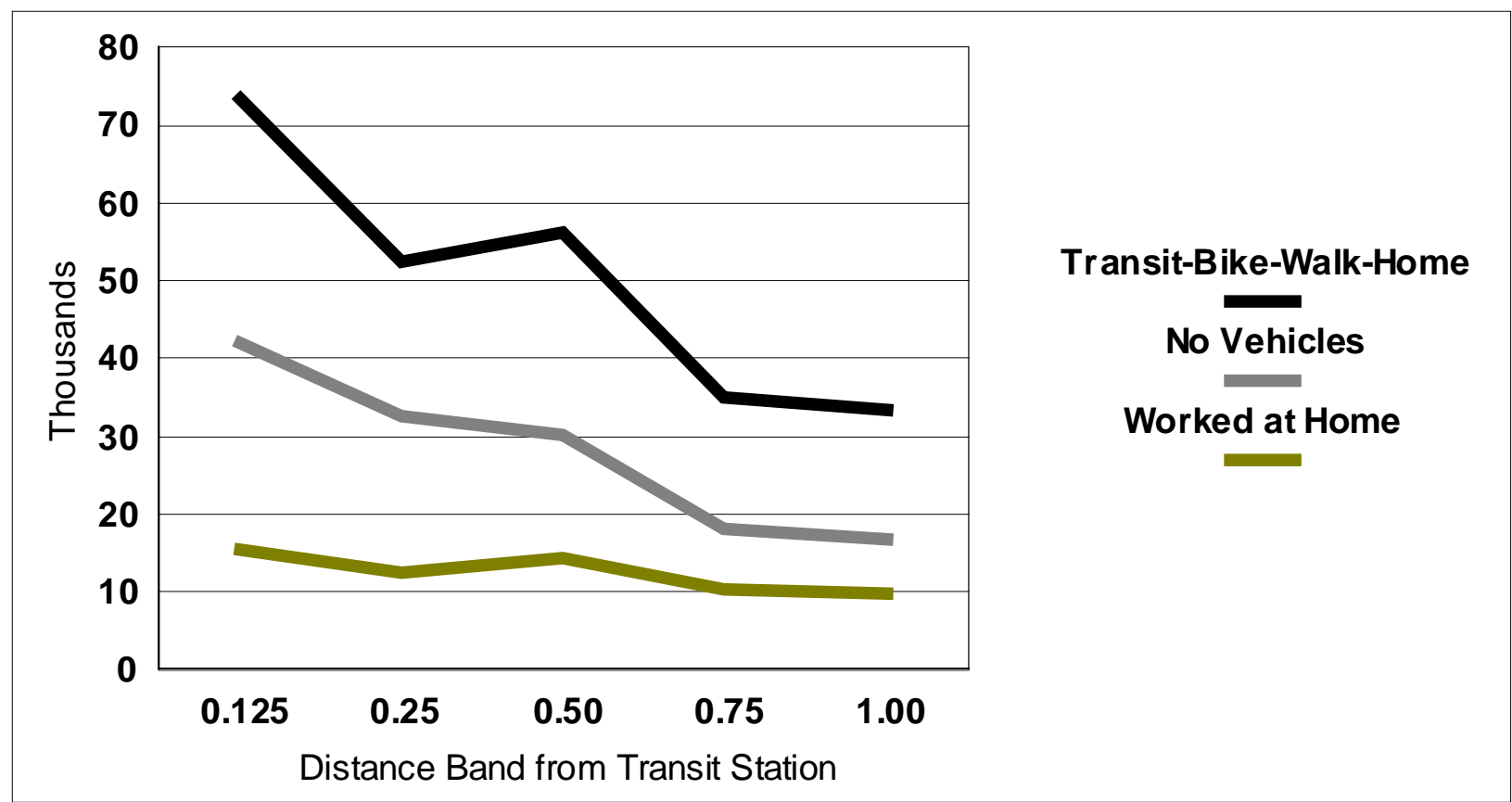

Figure 6.2: Share of Transit Region Change in Selected Commuting Mode Choice, Households without Vehicles and Workers Working at Home by Distance Band from Bus Rapid Transit Stations, 2010-2016 
Table 6.4: Shift in Share of Commuting Mode Choice, Workers Working at Home and Household Vehicle Ownership with Respect to Streetcar Transit Proximity, 2010-2016

\begin{tabular}{lr|r|r|r|r}
\hline SCT STATION PROXIMITY & \multicolumn{7}{c}{ Station Share 2010-2016 } \\
\hline Commuting/Vehicle Metrics & $\mathbf{0 . 1 2 5}$ & $\mathbf{0 . 2 5}$ & $\mathbf{0 . 5}$ & $\mathbf{0 . 7 5}$ & $\mathbf{1}$ \\
\hline Commuting & & & & & \\
\hline Drove Alone/Carpooled & 26,382 & 31,630 & 23,081 & 27,350 & 26,252 \\
\hline Transit & 4,969 & 6,371 & 4,175 & 3,567 & 4,153 \\
\hline Bike & 1,757 & 1,578 & 954 & 1,465 & 1,710 \\
\hline Walked & 7,396 & 8,892 & 3,908 & 1,452 & 2,642 \\
\hline Other & 340 & 271 & 355 & 152 & 172 \\
\hline Worked at Home & 2,844 & 3,499 & 2,692 & 1,803 & 2,323 \\
\hline Total Workers & 43,992 & 52,810 & 35,538 & 35,717 & 37,622 \\
\hline Transit-Bike-Walk-Home & 16,966 & 20,340 & 11,729 & 6,822 & 10,828 \\
\hline Vehicles & & & & & \\
\hline Vehicle(s) Present & 30,308 & 36,491 & 24,626 & 25,766 & 26,850 \\
\hline No Vehicles & 8,579 & 11,482 & 4,551 & 4,104 & 4,510 \\
\hline Total Households & 38,896 & 47,982 & 29,186 & 29,879 & 31,369 \\
\hline
\end{tabular}




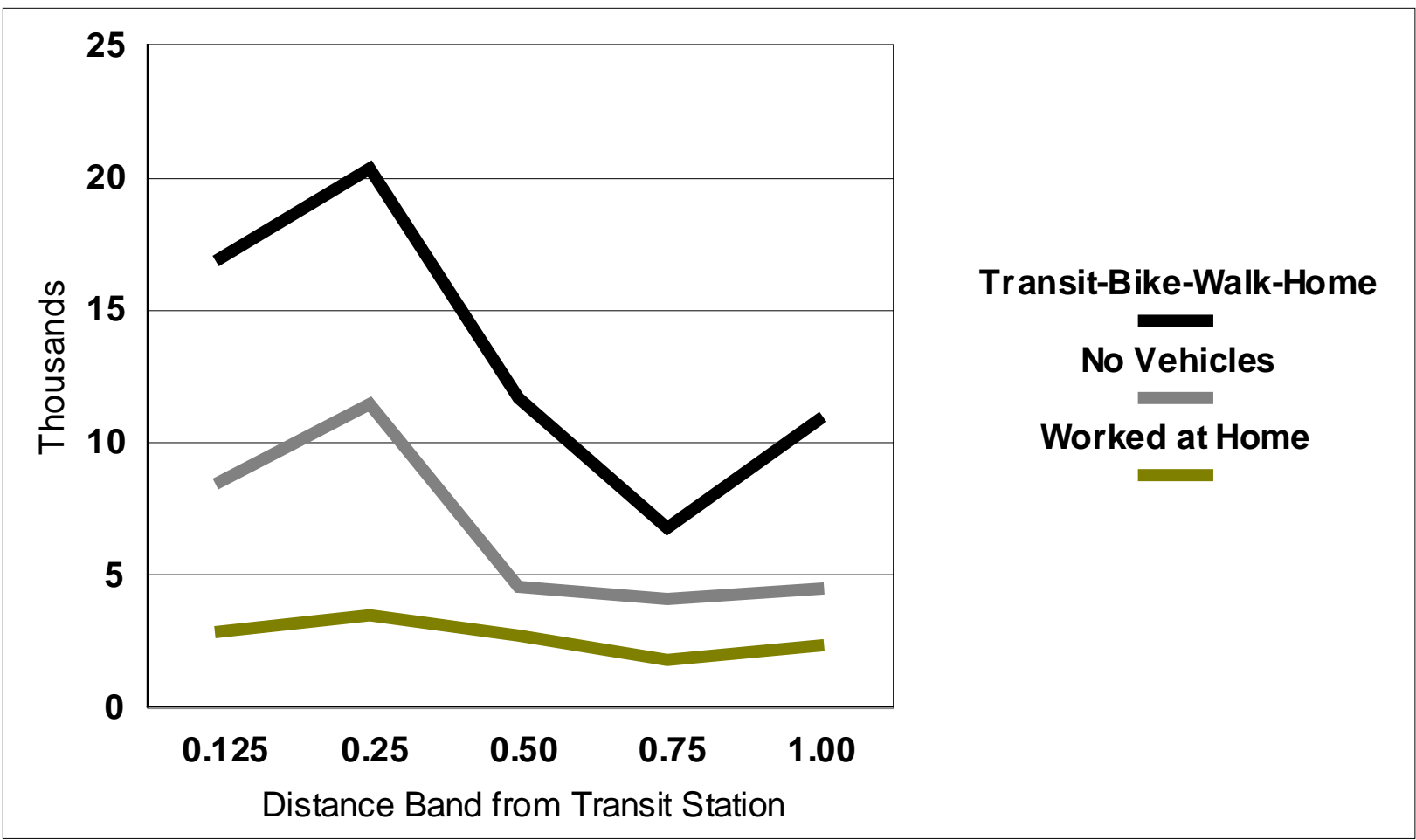

Figure 6.3: Share of Transit Region Change in Selected Commuting Mode Choice, Households without Vehicles and Workers Working at Home by Distance Band from Streetcar Transit Stations, 2010-2016 
Table 6.5: Shift in Share of Commuting Mode Choice, Workers Working at Home and Household Vehicle Ownership with Respect to Commuter Rail Transit Proximity, 2010-2016

\begin{tabular}{l|r|r|r|r|r}
\hline CRT STATION PROXIMITY & \multicolumn{7}{c}{ Station Share 2010-2016 } \\
\hline Commuting/Vehicle Metrics & $\mathbf{0 . 1 2 5}$ & $\mathbf{0 . 2 5}$ & $\mathbf{0 . 5}$ & $\mathbf{0 . 7 5}$ & $\mathbf{1}$ \\
\hline Commuting & & & & & \\
\hline Drove Alone/Carpooled & 138,760 & 109,698 & 153,768 & 201,832 & 210,815 \\
\hline Transit & 16,433 & 14,072 & 13,620 & 20,232 & 16,092 \\
\hline Bike & 1,861 & 2,842 & 3,586 & 3,286 & 2,794 \\
\hline Walked & 8,193 & 7,622 & 9,390 & 10,265 & 9,024 \\
\hline Other & 1,696 & 1,141 & 1,476 & 1,738 & 2,231 \\
\hline Worked at Home & 9,523 & 6,120 & 8,145 & 12,211 & 13,695 \\
\hline Total Workers & 177,419 & 142,056 & 191,053 & 215,940 & 255,548 \\
\hline Transit-Bike-Walk-Home & 36,010 & 30,656 & 34,741 & 42,708 & 41,605 \\
\hline Vehicles & & & & & \\
\hline Vehicle(s) Present & 119,064 & 94,063 & 128,115 & 168,641 & 174,195 \\
\hline No Vehicles & 12,934 & 12,297 & 13,858 & 17,601 & 15,345 \\
\hline Total Households & 132,010 & 106,372 & 141,985 & 160,006 & 189,552 \\
\hline
\end{tabular}




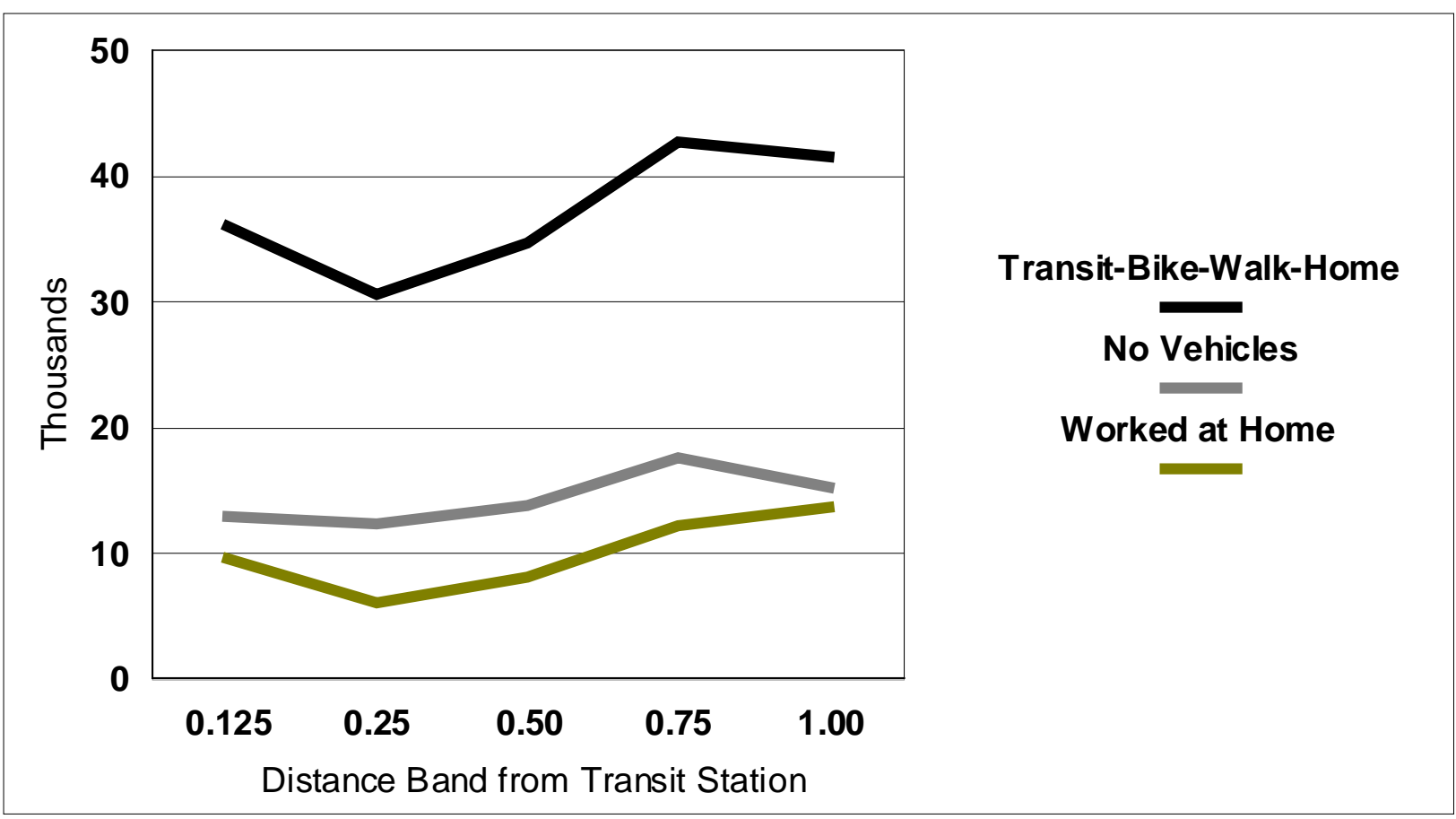

FIGURE 6.4: SHARE OF TRANSIT REGION CHANGE IN SELECTED COMMUTING MODE CHOICE, HOUSEHOLDS WITHOUT VEHICLES AND WORKERS WORKING AT HOME BY DISTANCE BAND FROM COMMUTER RAIL TRANSIT STATIONS, 2010-2016 


\section{REFERENCES}

Ewing, Reid, Guang Tian, and Torrey Lyons, College of Architecture + Planning University of Utah. Preston Stinger Fehr \& Peers Associates. Rachel Weinberger, Ben Kaufman, and Kevin Shivley Nelson\Nygaard Consulting Associates (2017). Trip and Parking Generation at TransitOriented Developments. Portland, OR: Portland State University, National Institute for Transportation and Communities.

Renne, John L. (2009) From transit-adjacent to transit-oriented development, Local Environment, 14:1, 1-15, DOI: 10.1080/13549830802522376 
This page intentionally left blank. 


\subsection{THE LINK BETWEEN JOBS-WORKER BALANCE BY INCOME AND ECONOMIC GROUP WITH RESPECT TO TRANSIT STATION PROXIMITY}

\subsection{OVERVIEW}

This chapter focuses on the balance of workplaces and residences near Fixed-Route Transit (FRT) stations by transit mode, segmented into wage and job sector categories. Transit modes include bus rapid transit (BRT), commuter rail (CRT), streetcar (SCT), and light rail (LRT).

This chapter focuses on balance dynamics before, during and after the Great Recession for 2mile distance bands from transit stations. The distance bands produce a neighborhood-scale commuter shed around transit stations that reveal whether commuters have responded to workforce pressures by locating more or less near transit stations.

This chapter introduces the concept, prior research approaches and findings. Next, it will consider the research question, theory, data, and design. It will then report and discuss results, followed by policy implications and further research opportunities. Lastly, the appendix provides extensive reporting on the study results in table format.

\subsection{INTRODUCTION}

A relative balance of employment and workers' residences in a given neighborhood is missing in urban areas suffering from the spatial mismatch problem, in which segregated minority populations are spatially separated from their jobs, precipitating long commutes that in most cases require automobile ownership as a prerequisite to access. This presents some members of these communities with financial hardship. As auto-induced sprawl accelerated in the midtwentieth century, jobs followed housing beyond the urban core. The dispersed nature of land uses in suburbia virtually guaranteed an imbalance between jobs and housing. A lack of balance is therefore a ubiquitous feature across U.S. metropolitan areas.

Increasing the relative level of balance has been used by some planners to improve job accessibility and reduce segregation, emissions, freeway congestion and vehicle-miles traveled (VMT) in a region (Cervero 1989; Ewing et al. 2016).

Transit-oriented development (TOD) is designed to improve regional accessibility and agglomeration economies through reduction of congestion and transportation costs (Nelson 2015; Cervero 2006). A main tenet of TOD policy is to increase land use mix, or the variety of land uses in each neighborhood (Renne et al. 2016). The principle land uses needed in TODs are residential and employment uses, which are the two constituent components considered in the jobs-worker balance. Mixing these at the station provides higher local accessibility in the form of more useful walkable places, while also increasing regional accessibility, with greater mobility through close proximity to a regional transit network. 


\subsection{PRIOR RESEARCH}

Kain (1968, 1992) and Cervero (1989) produced seminal works on the spatial mismatch hypothesis. Kain (1968) proposed three hypotheses about racial segregation in housing: 1) it affects the distribution of black employment, 2) it reduces black job opportunity, and that 3) postwar suburbanization of employment has seriously aggravated the problem. Cervero (1989) argued that suburban sprawl had driven commuters ever farther from their jobs, and exclusionary zoning and local undersupply of housing had priced many households out of residential locations near places of employment.

The balance between jobs and workers has been measured in various ways. Stoker \& Ewing (2014) define a "desirable commute-shed" as a 3-mile buffer around census tract centroids. This distance, they explained, was within the common distances that varied across the United States based on the size of the metropolitan area under study. The appropriate commuter-shed distance grows with the size of the MSA. In addition to variation in the neighborhood size chosen for analysis, the relative ratio accepted for "balance" has varied across studies, as well. Cervero (1989) noted a range of acceptable ratios that have been used in the literature.

Stoker \& Ewing (2014) used a spatial regression and multilevel modeling. Cervero (1989) fit a gravity model with OLS. Schleith et al. (2016) used the Transportation Problem linear programming model (TPLP) to identify the optimum level of commuting for an MSA and compared this to actual commuting level to determine when "excess commuting” was occurring. The TPLP approach aims to overcome the challenge presented by the subjective and contextual nature of the "ideal commute." It creates a zonal configuration chosen to accurately model worker and job locations across the study region. It computes the "theoretical minimum commute" for a region in terms of lowest optimal transportation costs in either time or distance, and aggregates for all workers in the region, then identifies commuting costs above that level as excessive. Regions with better job-worker balance will have more efficient zonal configurations on which to base their theoretical minimum commutes.

While U.S. cities generally exhibit imbalance in overall jobs-worker ratios, they are particularly out of balance for lower-income households, as attested in the spatial mismatch literature (Kain 1960, 1992). Evidence shows that areas balanced in terms of raw numbers of jobs and housing units can still require various income groups to commute elsewhere for their jobs. Stoker \& Ewing (2014) classify subgroups of jobs and workers to measure "income match" in a commutershed. They demonstrate that the use of a simple ratio between jobs and housing or workers in a given neighborhood fails to capture the significant variation that exists between jobs at a given income level and housing that can service workers at that level. Commutes have grown significantly over the last several decades (Ewing 1997, Cervero 1989), mainly driven by sprawling land use that separates the crucial needs of households and communities. This land use pattern has increased transportation costs for employee in general, but the pattern has had a disproportionate impact upon low-income employees residing in the urban core. 


\subsection{RESEARCH QUESTION AND DESIGN}

\section{Do FRT system neighborhoods improve in employment-worker balance across the study years? Which income groups see the greatest improvements?}

\subsubsection{Theory}

The spatial mismatch theory popularized by Kain (1968) comports only partially with traditional urban economic models, such as the AMM urban land use model (Muth 1969; Mills 1972; Alonso 1964) which, after von Thunen's (1826) agricultural land use model, hypothesizes the bid-rent gradient, in which residents and firms of a metropolitan area make a trade-off between land costs and transportation costs to maximize utility. The AMM model assumes that all employment is found within the central business district (CBD) at the center of the region, requiring all workers to commute to the center. Those who most desire centrality and gain the highest land rent from it (i.e., return on investment or highest utility) must bid for it, causing a land competition and succession process to proceed through time, driven by population and economic dynamics (Park, Burgess, McKenzie and Wirth 1925). Those who most desire land trade lower land costs farther away from the CBD with higher transportation costs to commute to the center. The position at which rent is highest for a given economic sector is the position relative to the center at which firms in that sector will locate (see figures 1 and 2 for graphical interpretations).

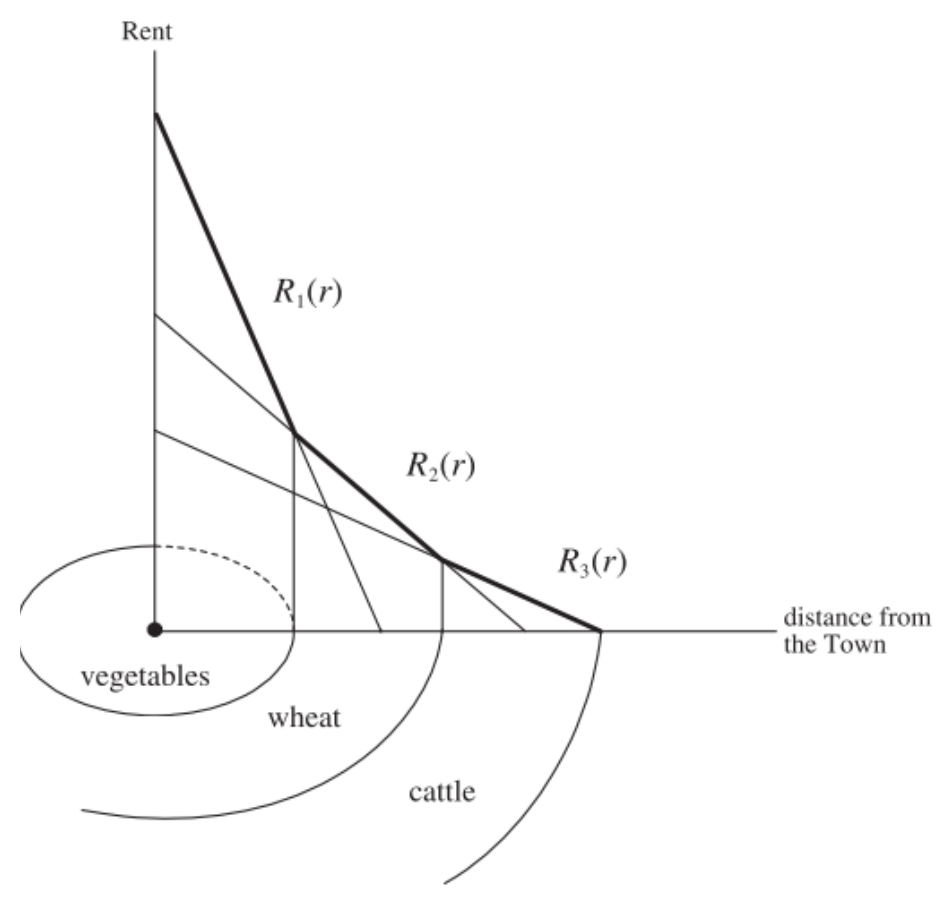

Figure 7.1. Graphic representation of von Thunen’s bid-rent gradient. Source: Fujita (2012). 


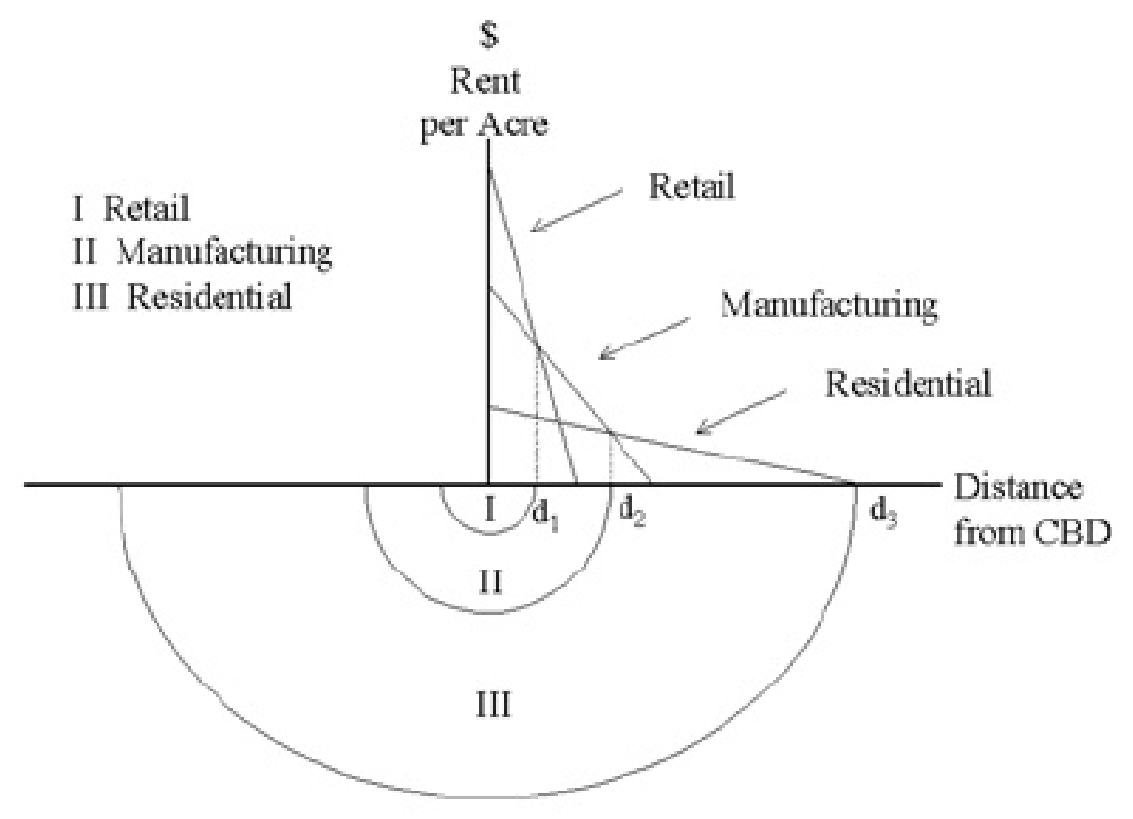

Figure 7.2. Graphic depiction of Bid Rent Theory of Alonso (1964).

Source: http://tutkimu.blogspot.com/2008/03/von-thnen-model-for-use-of-land.html.

The issue of spatial scale becomes important when considering the trade-offs made. Prior to the explosion of the automobile and concomitant land consumption beyond the CBD, the urban environment was far more constrained in spatial extent. Those wealthy enough to escape the city's harshest neighborhoods, such as industrial districts, would find respite on the outer edge of the CBD and in favored districts (Hoyt 1939) constrained by the transportation technology available for the time period. The phenomenon of the streetcar suburbs was the first large-scale expansion of this process. Hoyt's and Burgess's models describe a spatial segmentation by race and class existing in the urban core, although on a smaller spatial scale that matched the transportation technology of the time. In the suburban system, the automobile only unleashed a pattern already seen on a smaller scale in the city prior to its arrival. The automobile facilitated the largest wave of expansion for those who could afford the technology to leave the urban core. Those who could not afford it found themselves unable to leave.

Prior to the automobile's ascendancy, the AMM model was closer to the urban reality. Jobs were mostly in the urban core. When auto-driven expansion took many urban residents out to the suburbs, soon many jobs relying upon that population followed them, and the simple assumption of jobs locating solely in the center broke down. The present city is more accurately modeled as a system of many urban centers of varying size and use intensity mixed with some degree of dispersion (i.e., sprawl) (Hajrasouliha and Hamidi 2016). The higher the degree of dispersion, the lower the level of regional accessibility, and hence the higher the spatial mismatch (Ewing 1997). 


\subsubsection{Data}

The report utilizes three groupings of data: employee residence data classified by income level, employee work location data classified by income level, and transit station point data. Census block groups provide a fine spatial scale for the housing and employment figures; points are based on centroid locations.

The source of employment data is the Longitudinal Employer-Household Dynamics (LEHD) program which is part of the Center for Economic Studies at the U.S. Census Bureau.12 For all FGT systems studied, two-digit NAICS data are available annually from 2002 through 2015 at the census block level. LEHD data is provided in 3 separate tables: Worker Area Characteristics (WAC), Residence Area Characteristics (RAC) and Origin-Destination (O-D) tables. The O-D tables are essentially lookup tables that connect workers' residences ("origins") to their job locations ("destinations") by census block ID fields. The O-D tables are beyond the scope of this study but will be used in future research.

Because we need to analyze job presence over time, those jobs included in the study must be stationary. We therefore exclude more mobile jobs, including agriculture, construction, and mining jobs. We use NAICS job sectors to estimate wage levels per job, based on 2013 wage figures per job sector from County Business Patterns. Table 7.1 provides an enumeration of the wage classification.

The General Transit Feed Specification (GTFS) is used as a source of transit station centroid points based on X, Y coordinate pairs provided in the specification schema by the various transit authorities whose routes are included in the study.13

12 For details, see http://lehd.ces.census.gov/.

13 Data for most transit systems can be downloaded in GTFS format at transitfeeds.com. 


\subsubsection{Study Periods}

We evaluate balance of employment and workers overall and by income over three discrete time periods extending from before the Great Recession of the late 2000s, through the Great Recession itself, and afterward:

- 2007 covers the period of relatively constant growth from the early 2000s to the end of 2007. This is the pre-shock period that we call "pre-recession".

- $\quad \underline{2010}$ covers the period of the Great Recession. This is the "interrupted period”.

- $\quad \underline{2015}$ covers the period after the Great Recession which we call “post-recession”. This is the post-test period. Based on our theory, FRT station areas should capture a higher employment-worker balance for all income groups than their metropolitan areas as a whole. Rental groups will have higher balance near stations than owners.

\subsubsection{Fixed Route Transit Systems Studied}

Table 7.1 shows the FRT systems we include in our analysis. We excluded systems in the largest metropolitan areas (such as New York City, Chicago, Los Angeles) or metropolitan areas with a complex web of public transit (such as Boston, Philadelphia, San Francisco-Oakland) because we wanted to estimate outcomes associated with individual systems independent of the influences of multiple systems.

\subsubsection{Analytic Approach}

At the regional scale, jobs and workers will be in general balance. Many studies answer the challenge to accuracy posed by statistical enumeration units by using the smallest scale of data available, thus capturing a maximum of spatial variation. However, when analyzing subgroups some units can be too small to provide a useful analysis (Stoker \& Ewing 2014), and samplebased estimates are most accurate when based on as large an enumeration unit as possible (Plane \& Rogerson 1994). Most studies aggregate data to a larger neighborhood. In contrast to other studies, which define commuter-sheds of various sizes across regions studied, our emphasis on comparing FRT station areas to their larger regions guides the design of our study. We use distance bands around transit stations by mode as a treatment to compare to the control region (Stoker \& Ewing 2014).

We base our aggregations upon small units, census blocks, and gain greater sample sizes by aggregating to larger units, the 2-mile distance band surrounding transit stations, and the county or counties served by the transit system by mode. The choice is made for two reasons. First, it is done to model findings that the market capitalizes proximity to transit up to about 2 miles from the station for office and multi-family properties, as is noted in chapter 2 . Second, around transit stations one can assume, per the common theory, that policy aims to attract transit riders and active modes of transport. Literature shows that bicycle commute choice is greatly limited by long bicycling distances (Handy and Xing 2011). Moreover, the bicycle commuter located near transit is theoretically likely to be riding the bicycle to the transit station to access transit as the primary means of commuting, which means that the measurement of time spent engaged in this 
split-mode commute must include one leg on a bike and a second on transit. Heinen et al. (2011) defines a short bicycle commute as $5 \mathrm{~km}$ or just over 3 miles. Given that this is a bicycle-only commute, a shorter distance of 2 miles or less may be a preferable distance to bike to a transit station for commuting purposes.

The study defines employment-worker balance as a simple ratio of workers at workplaces per workers at their residences overall and in several categories of income and job sector. Our approach involves classifying the data into subgroups based on income and NAICS employment sector groupings, with the goal of measuring differences in balance dynamics across each of these subgroupings.

The study will evaluate the following categories of employment-worker balance:

- Overall workers at workplaces per workers at home

- Upper-income workers at workplaces per upper-income workers at home. See table 7.1 for details.

- Middle-income workers at workplaces per middle-income workers at home

- Lower-income workers at workplaces per lower-income workers at home

- Workers at workplaces per workers at home by categories of NAICS job sectors. See table 7.2 for details.

The simple ratio between number of workers at employment locations and workers at residence locations balance at unity, or a value of 1 . Above a value of 1 , the ratio indicates a higher proportion of employees at work than those at their residences. Below a value of 1 , the ratio indicates more employees at home in the area than at work locations.

\subsubsection{Internal Capture}

While these figures reveal much about a given geography, they do not indicate whether workers both live and work in the same geography. Internal capture is the ratio of workers who live in the same geography as that in which they work. In future research we will expand our methodology to include internal capture analyses.

Table 7.1: Allocation of Jobs by Lower-, Middle-, and Upper-Wage Category

\begin{tabular}{|c|c|c|c|c|}
\hline NAICS & Description & $\begin{array}{c}\text { Mean Annual } \\
\text { Wages, } 2013\end{array}$ & $\begin{array}{c}\text { Wage } \\
\text { Category }\end{array}$ & $\begin{array}{c}\text { Share } \\
\text { of } \\
\text { Jobs }\end{array}$ \\
\hline 44 & Retail Trade & $\$ 25,779$ & Lower & \\
\hline 56 & Administrative, Support, Waste Mgmt., Remediation & $\$ 35,931$ & Lower & \\
\hline 61 & Educational Services & $\$ 35,427$ & Lower & \\
\hline 71 & Arts, Entertainment and Recreation & $\$ 32,188$ & Lower & \\
\hline 72 & Accommodation and Food Services & $\$ 17,453$ & Lower & \\
\hline \multirow[t]{2}{*}{81} & Other Services (except Public Administration) & $\$ 29,021$ & Lower & \\
\hline & \multicolumn{2}{|l|}{ Weighted Mean Wages and National Share of Jobs } & $\sim \$ 30,000$ & $\sim 33 \%$ \\
\hline 48 & Transportation and Warehousing & $\$ 45,171$ & Middle & \\
\hline
\end{tabular}




\begin{tabular}{|c|c|c|c|c|}
\hline NAICS & Description & $\begin{array}{c}\text { Mean Annual } \\
\text { Wages, } 2013\end{array}$ & $\begin{array}{c}\text { Wage } \\
\text { Category }\end{array}$ & $\begin{array}{c}\text { Share } \\
\text { of } \\
\text { Jobs }\end{array}$ \\
\hline 53 & Real Estate and Rental and Leasing & $\$ 46,813$ & Middle & \\
\hline 62 & Health Care and Social Assistance & $\$ 44,751$ & Middle & \\
\hline \multirow[t]{2}{*}{92} & Public Administration & $\$ 51,340$ & Middle & \\
\hline & \multicolumn{2}{|l|}{ Weighted Mean Wages and National Share of Jobs } & $\sim \$ 50,000$ & $\sim 33 \%$ \\
\hline 22 & Utilities & $\$ 94,239$ & Upper & \\
\hline 31 & Manufacturing & $\$ 54,258$ & Upper & \\
\hline 42 & Wholesale Trade & $\$ 65,385$ & Upper & \\
\hline 51 & Information & $\$ 83,677$ & Upper & \\
\hline 52 & Finance and Insurance & $\$ 88,677$ & Upper & \\
\hline 54 & Professional, Scientific and Technical Services & $\$ 75,890$ & Upper & \\
\hline \multirow[t]{2}{*}{55} & Management of Companies and Enterprises & $\$ 105,138$ & Upper & \\
\hline & \multicolumn{2}{|l|}{ Weighted Mean Wages and National Share of Jobs } & $\sim \$ 70,000$ & $34 \%$ \\
\hline
\end{tabular}

Source: Adapted from Nelson and Ganning (2015). 
Table 7.2 below lists the MSAs covered in the study by mode and to which "generation" the systems of each MSA belong. It is expected that each generation of transit will have various different characteristics, and thus will exhibit different ratios.

Table 7.2: Combinations of NAICS Sectors into Economic Groups for Analysis

\begin{tabular}{|c|c|}
\hline NAICS Code & NAICS Sector Title and Economic Group Name \\
\hline & Manufacturing \\
\hline \multirow[t]{2}{*}{$31-33$} & Manufacturing \\
\hline & Light Industrial \\
\hline 22 & Utilities \\
\hline 42 & Wholesale Trade \\
\hline \multirow[t]{2}{*}{$48-49$} & Transportation and Warehousing \\
\hline & Retail-Lodging-Food (“Ret-Lodge-Food”) \\
\hline $44-45$ & Retail Trade \\
\hline \multirow[t]{2}{*}{72} & Accommodation and Food Services \\
\hline & Knowledge \\
\hline 51 & Information \\
\hline \multirow[t]{2}{*}{54} & Professional, Scientific, and Technical Services \\
\hline & Office \\
\hline 52 & Finance and Insurance \\
\hline 53 & Real Estate and Rental and Leasing \\
\hline 55 & Management of Companies and Enterprises \\
\hline 56 & Administrative and Support, Waste Management, Remediation \\
\hline 81 & Other Services (except Public Administration) \\
\hline \multirow[t]{2}{*}{92} & Public Administration \\
\hline & Education \\
\hline \multirow[t]{2}{*}{61} & Educational Services \\
\hline & Health \\
\hline \multirow[t]{2}{*}{62} & Health Care and Social Assistance \\
\hline & Arts-Entertainment-Recreation (“Arts-Ent-Rec”) \\
\hline 71 & Arts, Entertainment, and Recreation \\
\hline
\end{tabular}

Source: Adapted from the North American Industrial Classification System. 
Table 7.3: Fixed Route Transit (FRT) Systems Studied for Employment-Worker Balance

\begin{tabular}{|c|c|c|c|c|c|c|c|}
\hline \multicolumn{2}{|c|}{ Light Rail Transit } & \multicolumn{2}{|c|}{ Bus Rapid Transit } & \multicolumn{2}{|c|}{ Streetcar Transit } & \multicolumn{2}{|c|}{ Commuter Rail Transit } \\
\hline 1st Generation & Year & Pioneer & Year & $\begin{array}{l}\text { 1st } \\
\text { Generation }\end{array}$ & Year & $\begin{array}{l}\text { 1st } \\
\text { Generation }\end{array}$ & Year \\
\hline Buffalo & 1984 & Pittsburgh & 1977 & Little Rock & 2004 & $\begin{array}{l}\text { Dallas-Fort } \\
\text { Worth }\end{array}$ & 1996 \\
\hline Cleveland & 1980 & $\begin{array}{l}\text { Pre- } \\
\text { Recession }\end{array}$ & & Portland & 2001 & $\begin{array}{l}\text { Miami Tri- } \\
\text { Rail }\end{array}$ & 1989 \\
\hline Pittsburgh & 1984 & $\begin{array}{l}\text { Eugene- } \\
\text { Springfield }\end{array}$ & 2007 & Seattle & 2007 & Minneapolis & 1997 \\
\hline Portland & 1986 & Kansas City & 2005 & Tacoma & 2003 & San Diego & 1995 \\
\hline Sacramento & 1987 & Las Vegas & 2004 & Tampa & 2002 & $\begin{array}{l}\text { San Jose- } \\
\text { Stockton }\end{array}$ & 1998 \\
\hline San Diego & 1981 & Stockton & 2007 & $\begin{array}{l}\text { 2nd } \\
\text { Generation }\end{array}$ & & $\begin{array}{l}\text { Seattle- } \\
\text { Tacoma }\end{array}$ & 2000 \\
\hline San Jose & 1987 & $\begin{array}{l}\text { Great } \\
\text { Recession }\end{array}$ & & Atlanta & 2014 & $\begin{array}{l}\text { Washington, } \\
\text { DC }\end{array}$ & $\begin{array}{c}\text { 1980s- } \\
90 \mathrm{~s}\end{array}$ \\
\hline $\begin{array}{l}\text { 2nd } \\
\text { Generation }\end{array}$ & & Cleveland & 2008 & Dallas & 2015 & $\begin{array}{l}\text { 2nd } \\
\text { Generation }\end{array}$ & \\
\hline Dallas & 1996 & Nashville & 2009 & Salt Lake City & 2013 & Albuquerque & 2006 \\
\hline Denver & 1994 & Phoenix & 2009 & Tucson & 2014 & Austin & 2010 \\
\hline Salt Lake City & 1999 & Reno & 2010 & & & Nashville & 2006 \\
\hline St. Louis & 1993 & $\begin{array}{l}\text { Salt Lake } \\
\text { City }\end{array}$ & 2008 & & & Orlando & 2014 \\
\hline 3rd Generation & & Seattle & 2010 & & & Portland & 2009 \\
\hline Charlotte & 2007 & $\begin{array}{l}\text { Post- } \\
\text { Recession }\end{array}$ & & & & Salt Lake City & 2008 \\
\hline Houston & 2004 & San Antonio & 2012 & & & & \\
\hline Minn.-St. Paul & 2004 & San Diego & 2014 & & & & \\
\hline Norfolk & 2011 & $\begin{array}{l}\text { Washington } \\
\text { DC }\end{array}$ & 2014 & & & & \\
\hline Phoenix & 2008 & & & & & & \\
\hline Seattle & 2003 & & & & & & \\
\hline
\end{tabular}




\subsection{RESULTS AND DISCUSSION}

Relative degrees of balance vary significantly by metropolitan area and transit mode. Differences in each metropolitan area's political, demographic, economic, and policy regimes introduce major variation in balance and its dynamics over time. No single wage or sector group shows change consistently across a large number of generational groupings, although in general retail, office, manufacturing, and education show flat amounts of change compared to other groups. Even greater variety in these sectors can be seen in the MSA groupings in the appendix.

The ratios between employment and housing indicate for all metropolitan areas across all of the transit categories for this study that in general, transit station areas to 2 miles from the station are coming into greater balance, either through fewer jobs or more housing locating near the station. Further in-depth study is required to ascertain the underlying cause of the ratio change.

There are a few cases in which the ratio changes in favor of the employment side of the ratio. For example, in 2nd-generation LRT, the arts sector group ratio increased. In pre-recession BRT the light industrial sector group gained in favor of employment by approximately $2 \%$. Arts and light industrial employment gained in ratio balance in LRT and SCT. CRT had the greatest degree of change of all transit modes, seeing a major shift towards residences in the education sector group. Otherwise, the study categories remained flat or changed in favor of residence.

The appendix provides a series of tables for each MSA by transit mode. Significant variation is further revealed in these tables. Of particular note are Nashville's BRT and CRT systems, along with Norfolk's LRT system. Several others saw major changes between 2011 and 2015, although to a smaller magnitude than Nashville and Norfolk.

The tables below present the FRT systems this study includes by generational grouping. 


\subsubsection{Light Rail Transit (LRT) Jobs-Worker Balance Before, During and After the Great Recession}

We report jobs-worker results for groups of LRT systems that were initiated during these time periods:

\section{0-1987 ( $1^{\text {st }}$ generation)}

\section{Light Rail Systems}

Year

Cleveland

1980

San Diego

1981

Buffalo

1984

Pittsburgh

1984

Portland

1986

San Jose

1987

Sacramento

1987

1993-1999 ( $2^{\text {nd }}$ generation)

\section{Light Rail Systems}

Year

St. Louis

1993

Denver

1994

Dallas

1996

Salt Lake City

1999

2003-2011 ( $3^{\text {rd }}$ generation)

\section{Light Rail Systems}

Year

Seattle

2003

Minneapolis-St. Paul

2004

Houston

2004

Charlotte

2007

Phoenix

2008

Norfolk

2011 
Table 7.4. LRT Jobs-Worker Balance Ratios and Change by Wage and Sector Group Across Years Before, During, and After Great Recession

\begin{tabular}{|c|c|c|c|c|}
\hline LRT 1st-Gen & 2007 & 2011 & 2015 & $2015 / 2011$ \\
\hline Overall Balance & 1.344 & 1.425 & 1.370 & $-3.87 \%$ \\
\hline \multicolumn{5}{|l|}{ Wage Group } \\
\hline Upper Wage & 1.211 & 1.241 & 1.213 & $-2.28 \%$ \\
\hline Middle Wage & 1.214 & 1.279 & 1.249 & $-2.30 \%$ \\
\hline Lower Wage & 1.114 & 1.146 & 1.129 & $-1.48 \%$ \\
\hline \multicolumn{5}{|l|}{ Economic Group } \\
\hline Manufacturing & 1.177 & 1.214 & 1.181 & $-2.74 \%$ \\
\hline Light Industrial & 1.155 & 1.163 & 1.140 & $-2.00 \%$ \\
\hline Retail-Lodging & 1.101 & 1.126 & 1.115 & $-0.91 \%$ \\
\hline Knowledge & 1.226 & 1.246 & 1.233 & $-1.03 \%$ \\
\hline Office & 1.198 & 1.276 & 1.238 & $-3.03 \%$ \\
\hline Education & 1.110 & 1.149 & 1.135 & $-1.20 \%$ \\
\hline Health & 1.235 & 1.248 & 1.227 & $-1.68 \%$ \\
\hline Arts-Ent-Rec & 1.095 & 1.162 & 1.148 & $-1.26 \%$ \\
\hline LRT 2nd-Gen & 2007 & 2011 & 2015 & 2015/2011 \\
\hline Overall Balance & 1.378 & 1.424 & 1.385 & $-2.76 \%$ \\
\hline \multicolumn{5}{|l|}{ Wage Group } \\
\hline Upper Wage & 0.823 & 0.836 & 0.826 & $-1.22 \%$ \\
\hline Middle Wage & 0.838 & 0.849 & 0.837 & $-1.41 \%$ \\
\hline Lower Wage & 0.783 & 0.787 & 0.776 & $-1.32 \%$ \\
\hline \multicolumn{5}{|l|}{ Economic Group } \\
\hline Manufacturing & 0.744 & 0.752 & 0.745 & $-0.84 \%$ \\
\hline Light Industrial & 0.809 & 0.820 & 0.794 & $-3.20 \%$ \\
\hline Retail-Lodging & 0.777 & 0.780 & 0.771 & $-1.17 \%$ \\
\hline Knowledge & 0.851 & 0.858 & 0.851 & $-0.79 \%$ \\
\hline Office & 0.853 & 0.870 & 0.850 & $-2.22 \%$ \\
\hline Education & 0.762 & 0.756 & 0.750 & $-0.83 \%$ \\
\hline Health & 0.828 & 0.828 & 0.825 & $-0.45 \%$ \\
\hline Arts-Ent-Rec & 0.808 & 0.823 & 0.842 & $2.27 \%$ \\
\hline
\end{tabular}


Table 7.4: LRT Jobs-Worker Balance Ratios and Change by Wage and Sector Group Across Years Before, During, and After Great Recession (continued)

\begin{tabular}{l|r|r|r|r}
\hline LRT 3rd-Gen & $\mathbf{2 0 0 7}$ & $\mathbf{2 0 1 1}$ & $\mathbf{2 0 1 5}$ & $\mathbf{2 0 1 5 / 2 0 1 1}$ \\
\hline Overall Balance & 3.071 & 3.354 & 3.075 & $-8.34 \%$ \\
\hline Wage Group & & & & \\
\hline Upper Wage & 1.458 & 1.508 & 1.483 & $-1.69 \%$ \\
\hline Middle Wage & 1.511 & 1.578 & 1.541 & $-2.39 \%$ \\
\hline Lower Wage & 1.307 & 1.374 & 1.318 & $-4.05 \%$ \\
\hline Economic Group & & & & $-4.72 \%$ \\
\hline Manufacturing & 1.311 & 1.348 & 1.284 & $-2.93 \%$ \\
\hline Light Industrial & 1.525 & 1.579 & 1.533 & $-1.53 \%$ \\
\hline Retail-Lodging & 1.233 & 1.291 & 1.271 & $-1.94 \%$ \\
\hline Knowledge & 1.495 & 1.528 & 1.498 & $-3.12 \%$ \\
\hline Office & 1.475 & 1.568 & 1.519 & $-4.19 \%$ \\
\hline Education & 1.347 & 1.391 & 1.333 & $-2.54 \%$ \\
\hline Health & 1.487 & 1.538 & 1.499 & $-2.00 \%$ \\
\hline Arts-Ent-Rec & 1.337 & 1.423 & 1.394 & \\
\hline
\end{tabular}

Change in balance in LRT systems by wage was small across the generations. By sector, the changes were also small, with most changes being less than $3 \%$. Third-generation systems saw the greatest change, as much as $-4.72 \%$ for a single sector group, manufacturing. Office, manufacturing and education, which saw the largest changes, changed $3 \%$ to $4 \%$ in most generations, tilting away from employment and towards residences. The overall trends between LRT generations indicates the greatest change occurred in the $3^{\text {rd }}$ generation, then the first, with the second having the lowest degree of change in the study period. In the first generation, the greatest change occurred in office employment per residence. Manufacturing also became more balanced. Upper and middle-wage employment showed approximately the same degree of change, around $2.3 \%$, while the lower-wage ratio was reduced by a smaller amount of only $1.48 \%$. Manufacturing and office ratio came closer to unity as either jobs were lost, or workers' residences gained in these sector groups.

First-generation ratios are slightly in favor of employment, being above 1 . While the degree of change differed between categories of the LRT $2^{\text {nd }}$-generation, overall the dynamics were in favor of housing. The ratios in the $2^{\text {nd }}$ generation are all below 1 , indicating a ratio in favor of residences in an area. To balance these areas more employment is needed especially in lowerwage jobs, such as retail and manufacturing. First-generation light rail systems together tracked relatively close to 1 ; closer than other transit modes. This trend does not show up in the overall balance ratio; it is only revealed by segmenting by wages or job sector groups. The $3^{\text {rd }}$ generation light rail group ratios indicate higher favor toward employment near transit, from 1.3 to 1.5 . 


\subsubsection{Bus Rapid Transit (BRT) Employment-Worker Balance Before, During and After the Great Recession}

We report jobs-worker results for groups of BRT systems that were initiated during these time periods:

Pittsburgh Pioneer 1970s-1980s

Pittsburgh

Pre-Recession 2004-2007

Las Vegas

Kansas City

Stockton

Eugene-Springfield

Great Recession 2008-2010

Las Vegas

Kansas City

Stockton

Eugene-Springfield

Cleveland

Salt Lake City

Nashville

Phoenix

Seattle

Reno

Post-Recession 2012-2014

San Antonio

San Diego
Year

1977-1983

Year

2004

2005

2007

2007

Year

2004

2005

2007

2007

2008

2008

2009

2009

2010

2010

Year

2012

2014 
Table 7.5. BRT Jobs-Worker Balance Ratios and Change by Wage and Sector Group Across Years Before, During, and After Great Recession

\begin{tabular}{|c|c|c|c|c|}
\hline Pittsburgh Pioneer & 2007 & 2011 & 2015 & 2015/2011 \\
\hline Overall Balance & 1.269 & 1.292 & 1.244 & $-3.78 \%$ \\
\hline \multicolumn{5}{|l|}{ Wage Group } \\
\hline Upper Wage & 1.228 & 1.234 & 1.194 & $-3.23 \%$ \\
\hline Middle Wage & 1.192 & 1.183 & 1.169 & $-1.17 \%$ \\
\hline Lower Wage & 1.148 & 1.150 & 1.135 & $-1.28 \%$ \\
\hline \multicolumn{5}{|l|}{ Economic Group } \\
\hline Manufacturing & 1.149 & 1.135 & 1.108 & $-2.37 \%$ \\
\hline Light Industrial & 1.209 & 1.201 & 1.141 & $-5.02 \%$ \\
\hline Retail-Lodging & 1.150 & 1.139 & 1.130 & $-0.85 \%$ \\
\hline Knowledge & 1.260 & 1.250 & 1.222 & $-2.24 \%$ \\
\hline Office & 1.216 & 1.222 & 1.185 & $-2.99 \%$ \\
\hline Education & 1.116 & 1.121 & 1.113 & $-0.70 \%$ \\
\hline Health & 1.190 & 1.196 & 1.190 & $-0.49 \%$ \\
\hline Arts-Ent-Rec & 1.170 & 1.251 & 1.192 & $-4.71 \%$ \\
\hline Pre-Recession BRT & 2007 & 2011 & 2015 & $2015 / 2011$ \\
\hline Overall Balance & 1.396 & 1.524 & 1.476 & $-3.17 \%$ \\
\hline \multicolumn{5}{|l|}{ Wage Group } \\
\hline Upper Wage & 1.165 & 1.199 & 1.161 & $-3.12 \%$ \\
\hline Middle Wage & 1.158 & 1.225 & 1.214 & $-0.88 \%$ \\
\hline Lower Wage & 1.129 & 1.164 & 1.148 & $-1.33 \%$ \\
\hline \multicolumn{5}{|l|}{ Economic Group } \\
\hline Manufacturing & 1.038 & 1.071 & 0.981 & $-8.46 \%$ \\
\hline Light Industrial & 1.098 & 1.132 & 1.156 & $2.18 \%$ \\
\hline Retail-Lodging & 1.126 & 1.174 & 1.163 & $-0.93 \%$ \\
\hline Knowledge & 1.196 & 1.230 & 1.208 & $-1.76 \%$ \\
\hline Office & 1.177 & 1.215 & 1.182 & $-2.70 \%$ \\
\hline Education & 1.176 & 1.215 & 1.188 & $-2.25 \%$ \\
\hline Health & 1.179 & 1.212 & 1.204 & $-0.67 \%$ \\
\hline Arts-Ent-Rec & 1.072 & 1.118 & 1.087 & $-2.76 \%$ \\
\hline
\end{tabular}


Table 7.5. BRT Jobs-Worker Balance Ratios and Change by Wage and Sector Group Across Years Before, During, and After Great Recession (continued)

\begin{tabular}{|c|c|c|c|c|}
\hline Great Recession BRT & 2007 & 2011 & 2015 & $2015 / 2011$ \\
\hline Overall Balance & 1.880 & 1.947 & 1.853 & $-4.84 \%$ \\
\hline \multicolumn{5}{|l|}{ Wage Group } \\
\hline Upper Wage & 1.310 & 1.350 & 1.328 & $-1.62 \%$ \\
\hline Middle Wage & 1.375 & 1.409 & 1.362 & $-3.38 \%$ \\
\hline Lower Wage & 1.228 & 1.262 & 1.237 & $-2.03 \%$ \\
\hline \multicolumn{5}{|l|}{ Economic Group } \\
\hline Manufacturing & 1.234 & 1.282 & 1.258 & $-1.87 \%$ \\
\hline Light Industrial & 1.358 & 1.406 & 1.380 & $-1.87 \%$ \\
\hline Retail-Lodging & 1.206 & 1.231 & 1.228 & $-0.18 \%$ \\
\hline Knowledge & 1.333 & 1.349 & 1.333 & $-1.22 \%$ \\
\hline Office & 1.358 & 1.422 & 1.344 & $-5.52 \%$ \\
\hline Education & 1.214 & 1.235 & 1.229 & $-0.48 \%$ \\
\hline Health & 1.307 & 1.327 & 1.307 & $-1.47 \%$ \\
\hline Arts-Ent-Rec & 1.212 & 1.254 & 1.263 & $0.72 \%$ \\
\hline Post-Recession BRT & 2007 & 2011 & 2015 & $2015 / 2011$ \\
\hline Overall Balance & 1.909 & 1.973 & 1.900 & $-3.70 \%$ \\
\hline \multicolumn{5}{|l|}{ Wage Group } \\
\hline Upper Wage & 1.184 & 1.206 & 1.181 & $-2.03 \%$ \\
\hline Middle Wage & 1.220 & 1.246 & 1.219 & $-2.19 \%$ \\
\hline Lower Wage & 1.127 & 1.151 & 1.128 & $-1.95 \%$ \\
\hline \multicolumn{5}{|l|}{ Economic Group } \\
\hline Manufacturing & 1.044 & 1.097 & 1.090 & $-0.66 \%$ \\
\hline Light Industrial & 1.084 & 1.080 & 1.035 & $-4.18 \%$ \\
\hline Retail-Lodging & 1.115 & 1.124 & 1.107 & $-1.49 \%$ \\
\hline Knowledge & 1.245 & 1.239 & 1.192 & $-3.82 \%$ \\
\hline Office & 1.207 & 1.222 & 1.215 & $-0.55 \%$ \\
\hline Education & 1.142 & 1.207 & 1.165 & $-3.43 \%$ \\
\hline Health & 1.256 & 1.292 & 1.270 & $-1.74 \%$ \\
\hline Arts-Ent-Rec & 1.081 & 1.126 & 1.080 & $-4.07 \%$ \\
\hline
\end{tabular}


Overall, all BRT generations tilted away from employment and towards residences, but in very small magnitudes. The overall change in balance in BRT systems by generation for the 3 generations are $-3.17 \%,-4.84 \%$, and $-3.7 \%$. In Pittsburgh and pre-recession BRT, upper-wage employment lost the most share. In recession-era systems, middle-wage job lost the most share. Post-recession, all wage categories lost share of the balance. BRT generations, wage categories all changed relatively equally. The exception was Pre-recession BRT routes have a relatively small degree of imbalance, which trend above a value of 1 , which indicates more employment than housing within 2 miles of the stations in these routes. Overall, the pre-recession routes have a lower incidence of imbalance than the BRT routes constructed later.

Sectors all tilted towards residential uses, most only slightly. The sectors tilting towards residences the most were manufacturing, light industrial, and office. The largest degree of change was in manufacturing, at approximately $8 \%$ change toward residences. Most changes were in smaller degrees, 2 percent or less.

\subsubsection{Streetcar Transit (SCT) Jobs-Worker Balance Before, During and After the Great Recession}

We report jobs-worker balance results for groups of SCT systems that were initiated during these time periods:

$\begin{array}{ll}\text { Pre-Recession 2001-2007 (1 } & \\ \text { generation) } & \text { Year } \\ \text { Portland } & 2001 \\ \text { Tampa } & 2002 \\ \text { Tacoma } & 2003 \\ \text { Little Rock } & 2004 \\ \text { Seattle } & 2007\end{array}$

Post-Recession 2013-2015 (2nd generation) Year

Salt Lake City 2013

Tucson 2014

Atlanta 2014

Dallas 2015 
Table 7.6.: SCT Jobs-Worker Balance Ratios and Change by Wage and Sector Group Across Years Before, During, and After Great Recession

\begin{tabular}{|c|c|c|c|c|}
\hline 1st-Gen SCT & 2007 & 2011 & 2015 & $2015 / 2011$ \\
\hline Overall Balance & 3.226 & 3.481 & 3.136 & $-9.91 \%$ \\
\hline \multicolumn{5}{|l|}{ Wage Group } \\
\hline Upper Wage & 1.481 & 1.517 & 1.493 & $-1.62 \%$ \\
\hline Middle Wage & 1.496 & 1.592 & 1.548 & $-2.74 \%$ \\
\hline Lower Wage & 1.371 & 1.452 & 1.408 & $-3.02 \%$ \\
\hline \multicolumn{5}{|l|}{ Economic Group } \\
\hline Manufacturing & 1.235 & 1.261 & 1.241 & $-1.63 \%$ \\
\hline Light Industrial & 1.515 & 1.563 & 1.548 & $-0.95 \%$ \\
\hline Retail-Lodging & 1.293 & 1.352 & 1.364 & $0.91 \%$ \\
\hline Knowledge & 1.567 & 1.552 & 1.542 & $-0.67 \%$ \\
\hline Office & 1.511 & 1.664 & 1.558 & $-6.34 \%$ \\
\hline Education & 1.517 & 1.514 & 1.482 & $-2.05 \%$ \\
\hline Health & 1.443 & 1.523 & 1.485 & $-2.47 \%$ \\
\hline Arts-Ent-Rec & 1.309 & 1.394 & 1.429 & $2.52 \%$ \\
\hline 2nd-Gen SCT & 2007 & 2011 & 2015 & $2015 / 2011$ \\
\hline Overall Balance & 1.757 & 1.660 & 1.598 & $-3.69 \%$ \\
\hline \multicolumn{5}{|l|}{ Wage Group } \\
\hline Upper Wage & 0.919 & 0.936 & 0.931 & $-0.55 \%$ \\
\hline Middle Wage & 0.984 & 0.956 & 0.972 & $1.64 \%$ \\
\hline Lower Wage & 0.857 & 0.863 & 0.862 & $-0.05 \%$ \\
\hline \multicolumn{5}{|l|}{ Economic Group } \\
\hline Manufacturing & 0.800 & 0.815 & 0.818 & $0.47 \%$ \\
\hline Light Industrial & 0.854 & 0.864 & 0.896 & $3.64 \%$ \\
\hline Retail-Lodging & 0.833 & 0.841 & 0.839 & $-0.25 \%$ \\
\hline Knowledge & 1.013 & 1.028 & 1.020 & $-0.87 \%$ \\
\hline Office & 0.973 & 0.966 & 0.964 & $-0.17 \%$ \\
\hline Education & 0.910 & 0.894 & 0.894 & $0.06 \%$ \\
\hline Health & 0.904 & 0.887 & 0.869 & $-2.05 \%$ \\
\hline Arts-Ent-Rec & 0.912 & 0.941 & 0.937 & $-0.44 \%$ \\
\hline
\end{tabular}


Streetcar change across the generations overall are significantly tilted away from employment numbers at workplaces, $-9.91 \%$ and $-3.69 \%$. Most changes in balance were small. The biggest percent changes across the study years were in office, which saw a change of $-6.43 \%$, and light industrial, which saw a change of 3.64\%, one of the few sector groupings to increase in favor towards employment in our study. Wage groups saw significant change in the $1^{\text {st }}$-generation systems but modest changes in the $2^{\text {nd }}$ generation, which saw little change in upper and lowerwage balance, but a modest change toward employment in the middle-wage category.

Second-generation SCT systems tilted more towards worker residences than the first generation.

\subsubsection{Commuter Rail Transit (CRT) Jobs-Worker Balance Before, During and After the Great Recession}

We report balance results for groups of CRT systems that were initiated during these time periods:

\section{CRT Systems $\mathbf{1}^{\text {st }}$ Generation}

Miami Tri-Rail

San Diego

Dallas-Fort Worth

Minneapolis

San Jose-Stockton

Seattle-Tacoma

CRT System $2^{\text {nd }}$ Generation

Albuquerque-Santa Fe

Nashville

Salt Lake City

Portland

Austin

Orlando
Year

1989

1995

1996

1997

1998

2000

Year

2006

2006

2008

2009

2010

2014 
Table 7.7: CRT Jobs-Worker Balance Ratios and Change by Wage and Sector Group Across Years Before, During, and After Great Recession

\begin{tabular}{|c|c|c|c|c|}
\hline 1st-Gen CRT & 2007 & 2011 & 2015 & 2015/2011 \\
\hline Overall Balance & 1.280 & 1.770 & 1.728 & $-2.32 \%$ \\
\hline \multicolumn{5}{|l|}{ Wage Group } \\
\hline Upper Wage & 0.849 & 1.104 & 1.098 & $-0.54 \%$ \\
\hline Middle Wage & 0.803 & 1.081 & 1.069 & $-1.17 \%$ \\
\hline Lower Wage & 0.759 & 1.025 & 1.015 & $-1.02 \%$ \\
\hline \multicolumn{5}{|l|}{ Economic Group } \\
\hline Manufacturing & 0.900 & 1.052 & 1.023 & $-2.69 \%$ \\
\hline Light Industrial & 0.860 & 1.049 & 1.037 & $-1.11 \%$ \\
\hline Retail-Lodging & 0.755 & 1.005 & 0.997 & $-0.85 \%$ \\
\hline Knowledge & 0.797 & 1.166 & 1.170 & $0.33 \%$ \\
\hline Office & 0.816 & 1.111 & 1.090 & $-1.90 \%$ \\
\hline Education & 0.718 & 1.003 & 1.003 & $0.00 \%$ \\
\hline Health & 0.779 & 1.021 & 1.021 & $0.01 \%$ \\
\hline Arts-Ent-Rec & 0.832 & 1.062 & 1.078 & $1.52 \%$ \\
\hline 2nd-Gen CRT & 2007 & 2011 & 2015 & 2015/2011 \\
\hline Overall Balance & 1.813 & 1.946 & 1.861 & $-4.36 \%$ \\
\hline \multicolumn{5}{|l|}{ Wage Group } \\
\hline Upper Wage & 1.004 & 1.029 & 1.036 & $0.77 \%$ \\
\hline Middle Wage & 1.061 & 1.102 & 1.053 & $-4.47 \%$ \\
\hline Lower Wage & 0.966 & 1.008 & 0.984 & $-2.35 \%$ \\
\hline \multicolumn{5}{|l|}{ Economic Group } \\
\hline Manufacturing & 1.039 & 1.030 & 1.040 & $0.93 \%$ \\
\hline Light Industrial & 1.044 & 1.096 & 1.069 & $-2.39 \%$ \\
\hline Retail-Lodging & 0.957 & 0.971 & 0.981 & $1.03 \%$ \\
\hline Knowledge & 1.001 & 1.045 & 1.061 & $1.53 \%$ \\
\hline Office & 1.022 & 1.084 & 1.052 & $-3.00 \%$ \\
\hline Education & 1.039 & 1.117 & 0.976 & $-12.62 \%$ \\
\hline Health & 0.962 & 0.993 & 0.990 & $-0.40 \%$ \\
\hline Arts-Ent-Rec & 0.902 & 0.900 & 0.878 & $-2.41 \%$ \\
\hline
\end{tabular}


Commuter rail changed overall by tilting more towards housing employees and more away from workplaces. As in the other transit modes, changes were mainly small in degree with some considerable exceptions. The second-generation CRT lines saw a significant drop in the ratio value for education. This may be due to a loss of education jobs. It may also be due to a gain in relevant housing, such as student housing. Second-generation systems, those from pre-recession and post-recession systems saw the most significant changes. In both generations balance tilted toward jobs only slightly in the upper-wage category; the other wage categories tilted more away from employment.

A significant degree of variation exists in balance across the transit modes, as well as across generations of transit systems. Later-generation transit systems are seeing the most significant changes. One example is Salt Lake City, with later-year CRT and SCT systems. Utah now leads the nation in home building but is only expanding that housing at a rate of $2.2 \%$. More housing, especially near transit, is needed to meet massive unmet demand (Nelson 2013).14

The great majority of changes by wage and sector groups in this study tilted more away from employment and toward residential uses. A few exceptions are of note, but are small in magnitude, including arts uses near $1^{\text {st }}$-generation CRT systems, and retail and knowledge uses near $2^{\text {nd }}$-generation CRT systems.

For more detailed data, we refer the reader to the Data Appendix on Jobs-Worker Balance by Income and Economic Group with Respect to Transit Station Proximity.

14 See recent Salt Lake Tribune news article. https://www.sltrib.com/news/politics/2019/05/23/utah-now-ranks-no-nation/. 


\subsection{IMPLICATIONS FOR TRANSIT AND LAND USE PLANNING}

Among this study's contributions are greater insight into which wage and industry sector groupings a given metropolitan area requires near transit stations in order to bring them into greater balance. The low overall degree of change for the study period keeps in place a significant imbalance in most cities between employment and residences near transit stations. Far more jobs exist near stations than residences for the relevant workers. Variation in change of balance is high between MSAs, much higher than between generational aggregations used in the study to categorize the systems. Individual metropolitan areas should consider their own balance figures and compare to the generational figures, as well as other comparable cities.

Improving balance can reduce congestion, improve accessibility and agglomeration economies (Nelson et al. 2013, Glaeser and Gottlieb 2009) and provide greater land use variety near transit stations. Chapter 9 also highlights the increase in transportation affordability enjoyed by lowwage workers near transit stations. For those policy makers, planners, and others who are interested in advancing transit-oriented development (TOD), these goals are of great importance.

Aided by the understanding of the implications for commuters of city spatial configuration, policy makers should produce housing policies aimed at providing housing for workers employed in a given economic sector or wage level that is needed in a given neighborhood. Housing location is relatively more flexible for most workers than employment location, and therefore a focus on housing in an area that is appropriate to a nearby employment sector or wage level may be more effective than providing jobs near housing of a given sector or wage level. Transportation is also of high importance, and policies should aim at providing greater local accessibility through built environments that help circulate more people without automobile use. Local-scale wage-housing cost balance is important to efforts to improve both housing and transportation efficiency and equity. Filling in the "missing middle" of housing types (e.g., townhouses, single-family attached units) would put density and affordability in greater reach for many cities.

Of final note, an important statistic indicates where the "low-hanging fruit" (i.e., the most easily realized opportunity set) exists: $5 \%$ of all residents and $48 \%$ of all jobs in the US are within a half-mile of FRT stations! Massive opportunity exists within 2 miles of transit stations to increase accessibility and jobs-housing balance, while supplying the shifting preference for TOD residence and transit-based commutes (Renne et al. 2016, Nelson 2013). 


\subsection{FUTURE RESEARCH}

In future research, we will analyze internal capture using the LEHD Origin-Destination table, which provides a census block ID for origin and destination of workers. Within each distance band a certain number of people will live and work in the same census block. Those blocks are identified by a dummy variable, allowing the workers involved to be summed.

Two-mile distance bands around each transit station will be the geography of interest. The analysis will identify whether both origin and destination are within the distance band, and are within 3 miles of each other, following Stoker \& Ewing (2014). An Origin-Destination Cost Matrix will determine the street network distance between each end of the commute. The transit network will be a constituent part of the overall cost distance network.

Some counties, especially large ones, have multiple land use typologies that differ significantly in population density, infrastructure, and other land use characteristics that make them more or less incommensurable. An example is Pima County, Arizona, which at over 9,000 square miles, most of which is rural, has only a few hundred square miles of urbanized land. Ratios measuring balance between land uses should compare places similar in typology. Future research will differentiate between urban and rural land in computing ratios. 


\section{REFERENCES}

Alonso, William. 1964. Location and Land Use. Cambridge, MA: Harvard University Press.

Cervero, Robert. 1989. “Jobs-Housing Balancing and Regional Mobility.” Journal of the American Planning Association 55 (December 2014): 136-50.

https://doi.org/10.1080/01944368908976014.

—. 2006. "Effects of Light and Commuter Rail Transit on Land Prices: Experiences in San Diego County.”

Ewing, Reid. 1997. “Is Los Angeles-Style Sprawl Desirable?” Journal of the American Planning Association 63 (1): 107-26. https://doi.org/10.1080/01944369708975728.

Ewing, Reid, Shima Hamidi, James B Grace, and Yehua Dennis. 2016. "Does Urban Sprawl Hold down Upward Mobility ?" Landscape and Urban Planning 148: 80-88. https://doi.org/10.1016/j.landurbplan.2015.11.012.

Fujita, Masahisa. 2012. "Regional Science and Urban Economics Thünen and the New Economic Geography 论.” Regional Science and Urban Economics 42 (6): 907-12. https://doi.org/10.1016/j.regsciurbeco.2011.12.002.

Glaeser, Edward L., and Joshua D. Gottlieb. 2009. "The Wealth of Cities: Agglomeration Economies and Spatial Equilibrium in the United States.” Journal of Economic Literature 47 (4): 983-1028. https://doi.org/10.1257/jel.47.4.983.

Hajrasouliha, Amir H., and Shima Hamidi. 2016. "The Typology of the American Metropolis: Monocentricity, Polycentricity, or Generalized Dispersion?” Urban Geography 3638 (April): 125. https://doi.org/10.1080/02723638.2016.1165386.

Handy, Susan L., and Yan Xing. 2011. "Factors Correlated with Bicycle Commuting: A Study in Six Small U.S. Cities.” International Journal of Sustainable Transportation 5 (2): 91-110. https://doi.org/10.1080/15568310903514789.

Heinen, Eva, Kees Maat, and Bert Van Wee. 2011. "The Role of Attitudes toward Characteristics of Bicycle Commuting on the Choice to Cycle to Work over Various Distances." Transportation Research Part D: Transport and Environment 16 (2): 102-9. https://doi.org/10.1016/j.trd.2010.08.010.

Hoyt, M., The Structure and Growth of Residential Neighborhoods in American Cities, Washington, DC: Federal Housing Administration, 1939.

Kain, John F. 1968. "Housing Segregation, Negro Employment, and Metropolitan Decentralization.” The Quarterly Journal of Economics 82 (2): 175-97. http://www.jstor.org/stable/1885893.

- 1992. "The Spatial Mismatch Hypothesis : Three Decades Later." Housing Policy Debate 3 (2): 371-460. https://doi.org/10.1080/10511482.1992.9521100. 
Mills, Edwin S. 1972. "Markets and Efficient Resource Allocation in Urban Areas.” The Swedish Journal of Economics 74 (1): 100-113. http://www.jstor.org/stable/3439012.

Muth, Richard F. 1969. Cities and Housing: The Spatial Pattern of Urban Residential Land Use. Chicago: University of Chicago Press.

Nelson, Arthur, Bruce Appleyard, Shyam Kannan, Reid Ewing, Matt Miller, and Dejan Eskic. 2013. "Bus Rapid Transit and Economic Development: Case Study of the Eugene-Springfield BRT System.” Journal of Public Transportation 16 (3): 41-57. https://doi.org/10.5038/23750901.16.3.3.

Nelson, Arthur C. 2013. Reshaping Metropolitan America Development Trends and Opportunities to 2030. Washington, DC: Island Press.

\section{_. 2015. “TRANSIT-ORIENTED DEVELOPMENTS MAKE A DIFFERENCE IN JOB LOCATION *."}

Nelson, Arthur C, and Joanna Ganning. 2015. “National Study of BRT Development Outcomes,” no. November.

Park, Robert Ezra, E. W. Burgess, Roderick Duncan McKenzie, and Louis Wirth. 1925. The city. Chicago, Ill: University of Chicago Press.

Plane, David A., Peter A. Rogerson. The Geographical Analysis of Population with Applications to Planning \& Business. New York: John Wiley \& Sons, 1994.

Renne, John L, Tara Tolford, Shima Hamidi, Reid Ewing. 2016. “The Cost and Affordability Paradox of Transit- Oriented Development : A Comparison of Housing and Transportation Costs Across Transit-Oriented Development , Hybrid and Transit-Adjacent Development Station Typologies.” Housing Policy Debate 26 (4-5): 819-34.

https://doi.org/10.1080/10511482.2016.1193038.

Schleith, Daniel, Michael Widener, and Changjoo Kim. 2016. “An Examination of the JobsHousing Balance of Different Categories of Workers across 26 Metropolitan Regions.” Journal of Transport Geography 57: 145-60. https://doi.org/10.1016/j.jtrangeo.2016.10.008.

Stoker, Philip, and Reid Ewing. 2014. “Job - Worker Balance and Income Match in the United States,” no. August 2015. https://doi.org/10.1080/10511482.2013.852604.

Thünen, JH von. "Der isolierte Staat." Beziehung auf Landwirtschaft und Nationalökonomie (1826). 


\subsection{THE LINK BETWEEN FIXED ROUTE TRANSIT STATION PLANNING AND DESIGN, AND DEVELOPMENT OUTCOMES}

\subsection{OVERVIEW}

In Chapters 2, 3, and 5, we posed the notion that poor fixed route transit (FRT) station planning and design can suppress commercial market rents, employment and population/housing outcomes with respect to FRT station proximity. In this chapter, we present preliminary evidence of this. The Chapter:

- Begins with a review of the theory of the link between FRT systems and urban development patterns;

- Outlines principles of FRT station planning and design that advance development outcomes;

- Shows how externalities perhaps caused by features of FRT station planning and design may undermine expected development outcomes; and

- Applies these concepts to create a typology of FRT stations based on commercial market rent outcomes.

We offer implications for transit and land use planning.

\subsection{INTRODUCTION}

Here we review how FRT systems generally should lead to positive development outcomes around transit stations, outline principles of FRT station planning and design to advance positive development outcomes around transit stations, and show how negative externalities can undermine those outcomes.

\subsubsection{Transit and the Theory of Urban Development}

Conventional urban location theory articulated by Alonso (1964), Muth (1969) and Mills (1972) shows that in a monocentric city where all jobs are in the central business district (CBD), the cost of transportation increases as distance increases from the CBD at a declining rate, as a function of increasing land area of the commuting shed. Transportation costs thus affect land value so that the "bid rent" curve for land also declines as distance increases. Where transportation costs are lowest, in the CBD, land prices are highest. To afford higher land prices ("rent”) in the CBD, more economic exchange is needed, resulting in higher development intensities among office, retail, and high-value multifamily housing land uses among others. Economic activities that cannot compete for CBD locations are pushed outward to locations where they can outbid other land uses, a process called urban land use invasion and succession (Park and Burgess 1927). 
In relaxing the strict monocentric city model, one can imagine the same principles at work only at smaller scales that are distributed across the landscape. For instance, in focusing transportation activity at nodes, rail transit stations can become small version of CBDs. Economic activities will bid up land prices close to rail transit stations; lower value activity moves away from transitions to location where they can outbid competing land uses.

One consequence of this sorting of land uses is the assembly of economic activities that can create agglomeration economies that can perpetuate and expand economic productivity. The American Public Transit Association notes:

There has been significant attention in the transportation research field regarding the extent to which public transportation investment supports “agglomeration economies” -the ability of business firms to realize productivity gains because of greater market access. One particular way to get at this same issue is to consider the emerging role of public transportation in enabling the growth of technology-oriented business sectors that are fast growing drivers of America's economy. To a significant degree, businesses in this sector of the economy tend to cluster (agglomerate) in specific urban locations where they can best access research centers, information sharing and a large, skilled workforce (Weisbrod, Cuter, and Duncan 2013: 5)

Transit is an important component in the growth of cities and their metropolitan areas (Glaeser, 2010, 2011). Since World War II, however, the rise of the automobile has challenged this notion. Highway expansion has allowed metropolitan areas to become ever larger as economies of agglomeration in some sectors are exploited through dispersion (Ciccone and Hall, 1996). Nonetheless, if metropolitan areas grow too large, highway congestion becomes a counterproductive force (Bogart, 1998; Boarnet, 1997; Boarnet and Haughwout, 2000).

One role of modern-day transit is to offset the adverse effects of highway congestion effects on agglomeration economies. Voith (1998) characterizes public transit as essentially "noncongestible" and is best suited to sustaining agglomeration economies in downtowns and secondary activity centers, and along the corridors that connect nodes (see also Nelson et al., 2009; Littman, 2009; Graham, 2007). The bottom line is that FRT systems and their stations should generate development around them.

\subsubsection{Principles of Transit Station Planning and Design to Advance Development}

In 2012, the Transit Cooperative Research Program (TCRP) publish its report, Guidelines for Providing Access to Public Transportation Stations (Coffel et al, 2012) that we use substantially for this discussion. It identifies these selected elements of transit station planning and design:

- Providing access to rapid transit stations should be a cooperative effort by appropriate transit and transportation agencies coordinated with planning agencies and engaging the surrounding community.

- Station access plans should result from comprehensive and cooperative planning processes that identify needs and opportunities and lead to effective and accepted results. 
- Station access generally should be multi-modal.

- The predominant access travel modes depend upon type of land use, street spacing, and development density, among other factors. Walking dominates station access in the city center and in contiguous high-density residential areas. Both walking and bus access are the main means of reaching stations within the central city.

- Improvements to station access should consider the planned build-out of the station area so as not to conflict with or inhibit future planning.

- Development adjacent to stations should feature transit-oriented design characteristics (e.g., pedestrian-friendly, direct transit access from local land uses) to maximize ridership potential.

- Pedestrian circulation should form the foundation of the station access plan. Transit passengers walk between home and bus stops, between bus stops and station entrances, and between parking facilities and station entrances. They then walk through the station to the rail or bus platforms. Each step of this trip should be convenient and safe.

(Adapted mostly verbatim from Coffel et al. 2012: 2-3)

The vast literature on FRT station planning and design may boil down to these over-arching principles:

- Reduce adverse impacts of transit stations on surrounding land uses;

- Facilitate positive interactions between land uses near stations; and

- Maximize accessibility of passengers to transit stations and nearby land uses.

Unfortunately, as we will show below, poor station planning and design can actually undermine these principles thereby dampening development outcomes.

\subsubsection{Negative Externalities and Development Outcomes}

Transit stations themselves can be nuisances such that land value may be dampened very near them. The market capitalizes both positive amenity effects of rail station proximity as well as negative amenity effects such as those associated with noise and congestion (Nelson and McCleksy 1990; Nelson 1992). So long as positive amenity effects outweigh negative ones, the bid rent gradient will be sloping downward and away from rail transit stations. In theory, however, it is possible for negative amenity effects to outweigh positive ones. These interactions are illustrated in Figure 8.1, described as follows:

The line $\mathrm{R}^{\mathrm{a}}$ shows the land rent (R) curve with full amenity ("a” for positive amenity) value from a rail transit station, $\mathrm{u}_{0}$, outward to a point, $\mathrm{u}_{1}$, where the amenity effects of rail transit proximity disappear, beyond which the overall market rent, $\mathrm{R}^{\mathrm{m}}$ is revealed. 
Negative effects of rail transit stations are shown in line $\mathrm{R}^{\mathrm{n}}$ (" $\mathrm{n}$ ” for negative amenity). As distance from the rail station increases, the negative amenity effects are reduced until they become zero at $\mathrm{u}^{1}$.

Positive and negative amenity effects interact in the market leading to overall positive or negative bid rent curves with respect to distance from rail transit stations to $\mathrm{u}_{1}$. Line $\mathrm{R}^{\mathrm{a}}+$ $\mathrm{R}^{\mathrm{n}}{ }_{1}$ is revealed where overall positive amenity effects outweigh negative ones. Line $\mathrm{R}^{\mathrm{a}}+$ $\mathrm{R}^{\mathrm{n}}{ }_{2}$ is revealed where overall positive amenity effects outweigh positive ones. Overall effects disappear at $\mathrm{u}_{1}$ beyond which market rent, $\mathrm{R}^{\mathrm{m}}$, in the absence of positive and negative amenity is revealed.

While numerous studies show negative bid rent gradients with respect to distance from rail transit stations - meaning the market values proximity to transit stations, others reveal that positive rent gradients occur meaning negative externalities are present that may stifle development (Higgins and Kanaroglou 2016).

We now pose a very basic typology of transit stations based on whether they may be considered good, bad or even ugly based on how the real estate market responds to them. 


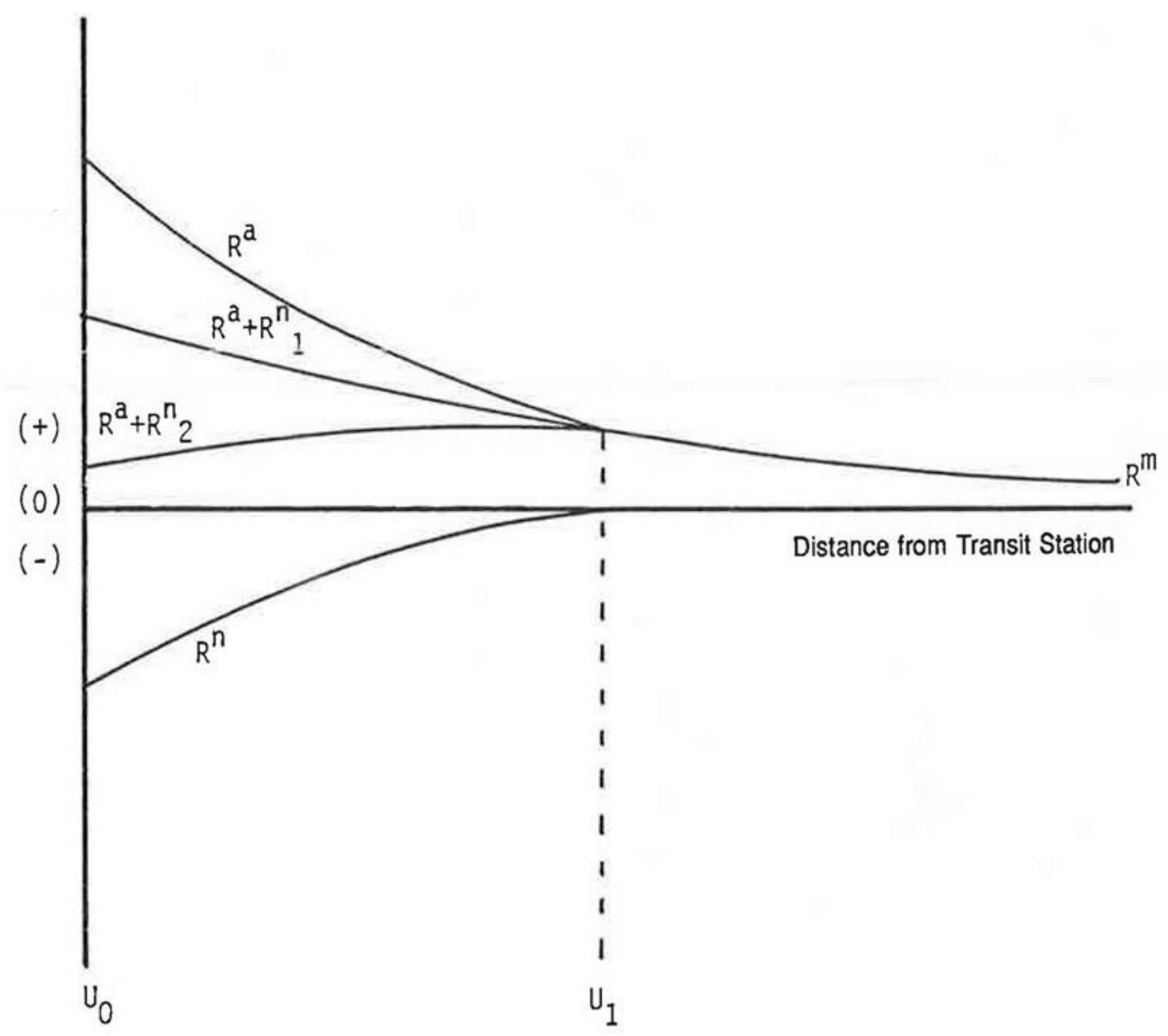

Figure 8.1: Positive Amenity $\left(\mathrm{R}^{\mathrm{a}}\right)$ and Negative Amenity $\left(\mathrm{R}^{\mathrm{n}}\right)$ influences of transition stations on proximate property values 


\subsection{TOWARD A TYPOLOGY OF GOOD, BAD AND UGLY TRANSIT STATION PLANNING AND DESIGN}

Chapters 3 and 5 especially show that development near FRT stations is mixed. Although much development occurs very new transit stations - notably within a narrow band about one-eighth (0.125) mile around stations - development usually falls dramatically so that at the scale of a one-half mile around stations it may be difficult to detect whether transit stations impact development patterns.

Much is revealed in Chapter 2, where we estimated the rent premiums for office, multifamily and retail properties associated with transit station proximity. Recall that, based on an aggregate analysis of 17 light rail transit (LRT) systems, office rents with respect to LRT station proximity were positive in only the first (0.125-mile) distance band. Yet, analyses of each of those 17 systems individually showed considerable variation in rent premiums, reported in Table 8.1. We use market-based rental premium indicators to help understand outcomes to FRT station planning and design.

With apologies to the 1966 movie The Good, The Bad and The Ugly, we interpret rent premiums reported in Table 8.1 as follows. Our application of analysis reported in Table 8.1 relating to office LRT rents can be expanded to include other real estate for which there market transactions (such as sakes or rents) as well as other modes. Our Good-Bad-Ugly typology applies only to the commercial rental market outcomes and not to planning and design features per se. We will address some of these features in the next section.

Good outcomes are those with positive, statistically significant office rent premiums from LRT station proximity at least to about one-half (0.50) mile though ideally farther. These LRT systems have good outcomes:

- Charlotte - the negative but insignificant coefficient for the 0.375-mile distance band is anomalous;

- Dallas - there are positive rent premiums to the 0.875-mle distance band;

- Denver — where there are positive rent premiums to the 0.75-mle distance band;

- Norfolk - it has positive, significant distance bands to 0.50-mile though there were no cases ion the 0.375 -mile band and the first (0.125-mile) distance band was positive though statistically insignificant; and

- Portland - that has statistically significant distance bands to 1.625 mile.

We may consider Houston in this group though positive premiums extend to only the 0.375-mile distance band and the second (0.25-mile) distance band coefficient is not significant.

In these cases, office market rents with respect to LRT station proximity are positive, as expected by theory. Although there may be elements of transit station planning and design that create 
negative externalities the advantages of proximity outweigh externalities in the manner illustrated in Figure 8.1. 
Table 8.1: Annual Office Rents per Square Foot with Respect to LRT Station Proximity, Distance Band Regression Coefficients (Significant coefficients in bold red. See Chapter 2 for details)

\begin{tabular}{|c|c|c|c|c|c|c|c|c|c|c|c|c|c|c|c|c|c|}
\hline Variables & BUF & CHR & CLE & DAL & DEN & HOU & MSP & NOR & PHX & PIT & PDX & SAC & SLC & SD & SJ & SEA & STL \\
\hline \multicolumn{18}{|c|}{ Distance Band } \\
\hline $\begin{array}{l}<=0.125 \\
\text { mile }\end{array}$ & -0.105 & 0.198 & 0.099 & 0.139 & 0.066 & 0.245 & -0.042 & 0.189 & 0.011 & -0.099 & 0.156 & -0.087 & 0.046 & -0.149 & -0.195 & -0.050 & -0.168 \\
\hline $\begin{array}{l}>0.125- \\
<=0.250 \\
\text { mile }\end{array}$ & 0.008 & 0.148 & -0.025 & 0.043 & 0.065 & 0.032 & -0.053 & 0.341 & -0.016 & -0.074 & 0.125 & -0.171 & 0.090 & -0.082 & -0.224 & -0.041 & -0.089 \\
\hline $\begin{array}{l}>0.250- \\
<=0.375 \\
\text { mile }\end{array}$ & -0.049 & -0.023 & 0.053 & 0.112 & 0.065 & 0.286 & -0.076 & & -0.007 & 0.176 & 0.153 & 0.006 & -0.118 & -0.109 & -0.180 & 0.047 & -0.087 \\
\hline $\begin{array}{l}>0.370- \\
<=0.500 \\
\text { mile }\end{array}$ & 0.209 & 0.182 & -0.004 & 0.070 & 0.056 & 0.084 & -0.063 & 0.188 & -0.088 & -0.032 & 0.184 & -0.160 & -0.073 & -0.172 & -0.228 & -0.032 & -0.023 \\
\hline $\begin{array}{l}>0.500- \\
<=0.625 \\
\text { mile }\end{array}$ & -0.175 & -0.031 & -0.073 & 0.051 & 0.047 & 0.094 & -0.033 & 0.186 & -0.063 & 0.037 & 0.159 & -0.008 & 0.211 & -0.142 & -0.217 & -0.083 & 0.064 \\
\hline $\begin{array}{l}>0.625- \\
<=0.750 \\
\text { mile }\end{array}$ & & 0.126 & 0.079 & 0.078 & 0.026 & -0.387 & 0.071 & 0.130 & -0.064 & -0.033 & 0.082 & -0.131 & 0.089 & -0.233 & -0.191 & 0.025 & 0.003 \\
\hline $\begin{array}{l}>0.750- \\
<=0.875 \\
\text { mile }\end{array}$ & & 0.028 & -0.226 & 0.109 & -0.017 & 0.239 & -0.020 & 0.040 & -0.154 & 0.158 & 0.099 & 0.165 & -0.056 & -0.101 & -0.221 & -0.048 & 0.137 \\
\hline $\begin{array}{l}>0.875- \\
<=1.000 \\
\text { mile }\end{array}$ & -0.580 & 0.312 & 0.033 & -0.012 & 0.007 & 0.240 & -0.188 & -0.156 & -0.195 & -0.071 & 0.133 & 0.153 & -0.218 & -0.084 & -0.210 & -0.105 & -0.029 \\
\hline $\begin{array}{l}>1.000- \\
<=1.125 \\
\text { mile }\end{array}$ & -0.089 & 0.227 & 0.053 & -0.070 & 0.007 & 0.086 & -0.102 & -0.014 & -0.189 & -0.058 & 0.003 & 0.063 & -0.068 & -0.135 & -0.153 & -0.061 & 0.005 \\
\hline $\begin{array}{l}>1.125- \\
<=1.250 \\
\text { mile }\end{array}$ & & 0.298 & 0.012 & -0.100 & 0.041 & 0.191 & -0.332 & 0.200 & -0.183 & -0.134 & 0.126 & 0.114 & -0.105 & -0.169 & -0.125 & -0.215 & -0.011 \\
\hline $\begin{array}{l}>1.250- \\
<=1.375 \\
\text { mile }\end{array}$ & & 0.089 & -0.042 & 0.003 & -0.029 & 0.523 & 0.013 & 0.575 & -0.035 & 0.029 & 0.131 & 0.135 & -0.046 & -0.151 & -0.142 & -0.171 & 0.081 \\
\hline $\begin{array}{l}>1.370- \\
<=1.500 \\
\text { mile }\end{array}$ & 0.138 & 0.019 & -0.020 & -0.213 & 0.025 & 0.527 & 0.167 & & -0.026 & 0.031 & 0.171 & -0.205 & -0.033 & -0.095 & -0.096 & -0.054 & -0.084 \\
\hline $\begin{array}{l}>1.500- \\
<=1.625 \\
\text { mile }\end{array}$ & -0.010 & 0.047 & -0.004 & -0.036 & -0.078 & 0.077 & -0.195 & & -0.081 & 0.071 & 0.283 & -0.160 & -0.008 & -0.576 & -0.143 & -0.107 & -0.157 \\
\hline
\end{tabular}




\begin{tabular}{|c|c|c|c|c|c|c|c|c|c|c|c|c|c|c|c|c|c|}
\hline Variables & BUF & CHR & CLE & DAL & DEN & HOU & MSP & NOR & PHX & PIT & PDX & SAC & SLC & SD & SJ & SEA & STL \\
\hline $\begin{array}{l}>1.625- \\
<=1.750 \\
\text { mile }\end{array}$ & 0.029 & 0.102 & -0.073 & -0.076 & -0.069 & 0.186 & -0.132 & 0.298 & -0.145 & 0.009 & 0.075 & -0.061 & -0.060 & -0.390 & -0.024 & -0.194 & -0.275 \\
\hline $\begin{array}{l}>1.750- \\
<=1.875 \\
\text { mile }\end{array}$ & & 0.027 & -0.199 & -0.190 & -0.040 & -1.922 & -0.184 & -0.105 & -0.110 & 0.085 & -0.136 & 0.166 & -0.229 & -0.074 & -0.215 & -0.160 & 0.119 \\
\hline $\begin{array}{l}>1.875- \\
<=2.000 \\
\text { mile }\end{array}$ & -0.105 & 0.079 & 0.327 & & -0.032 & 0.610 & 0.152 & & -0.039 & -0.007 & -0.450 & 0.466 & -0.027 & -0.098 & 0.020 & -0.108 & 0.166 \\
\hline \multicolumn{18}{|c|}{ Model Performance } \\
\hline Cases & 182 & $\begin{array}{r}521.00 \\
0 \\
\end{array}$ & 517 & 2,064 & 4,978 & 557 & 605 & 89 & 1,318 & 920 & 497 & 185 & 417 & 924 & 627 & 748 & 603 \\
\hline $\begin{array}{l}\text { R2, } \\
\text { adjusted }\end{array}$ & 0.286 & 0.437 & 0.297 & 0.220 & 0.167 & 0.257 & 0.062 & 0.394 & 0.413 & 0.391 & 0.280 & 0.135 & 0.293 & 0.254 & 0.251 & 0.346 & 0.339 \\
\hline F-ratio & 4.292 & 14.172 & 9.078 & $\begin{array}{r}22.50 \\
5 \\
\end{array}$ & $\begin{array}{r}38.03 \\
7 \\
\end{array}$ & 8.110 & 2.479 & 3.491 & $\begin{array}{r}35.35 \\
8 \\
\end{array}$ & $\begin{array}{r}22.89 \\
6 \\
\end{array}$ & 8.150 & 2.061 & 7.386 & $\begin{array}{r}12.63 \\
1 \\
\end{array}$ & 8.772 & $\begin{array}{r}15.66 \\
5 \\
\end{array}$ & $\begin{array}{r}12.45 \\
2 \\
\end{array}$ \\
\hline \multicolumn{18}{|c|}{ Descriptive Statistics } \\
\hline $\begin{array}{l}\text { Rent } \\
\text { Square } \\
\text { Foot/Yea } \\
\text { r } \\
\end{array}$ & $\begin{array}{r}\$ 15.5 \\
6 \\
\end{array}$ & $\$ 21.48$ & $\begin{array}{r}\$ 15.9 \\
7 \\
\end{array}$ & $\begin{array}{r}\$ 19.2 \\
5 \\
\end{array}$ & $\begin{array}{r}\$ 22.4 \\
3 \\
\end{array}$ & $\begin{array}{r}\$ 19.1 \\
3 \\
\end{array}$ & $\$ 15.45$ & $\begin{array}{r}\$ 16.6 \\
6 \\
\end{array}$ & $\begin{array}{r}\$ 18.9 \\
0 \\
\end{array}$ & $\begin{array}{r}\$ 18.9 \\
3 \\
\end{array}$ & $\begin{array}{r}\$ 21.4 \\
6 \\
\end{array}$ & $\begin{array}{r}\$ 20.3 \\
1 \\
\end{array}$ & $\begin{array}{r}\$ 19.2 \\
0 \\
\end{array}$ & $\begin{array}{r}\$ 27.4 \\
5 \\
\end{array}$ & $\begin{array}{r}\$ 40.8 \\
4 \\
\end{array}$ & $\begin{array}{r}\$ 26.3 \\
0 \\
\end{array}$ & $\begin{array}{r}\$ 18.0 \\
4 \\
\end{array}$ \\
\hline $\begin{array}{l}\text { Rent } \\
\text { Square } \\
\text { Foot/Yea } \\
\text { r (Ln) }\end{array}$ & 2.690 & 3.013 & 2.702 & 2.889 & 3.075 & 2.874 & 2.678 & 2.770 & 2.871 & 2.883 & 3.020 & 2.889 & 2.874 & 3.237 & 3.606 & 3.205 & 2.828 \\
\hline $\begin{array}{l}\text { Gross } \\
\text { Leasable } \\
\text { Area }\end{array}$ & $\begin{array}{r}55,17 \\
1\end{array}$ & 72,170 & $\begin{array}{r}70,24 \\
1\end{array}$ & $\begin{array}{r}81,92 \\
5\end{array}$ & $\begin{array}{r}33,61 \\
6\end{array}$ & $\begin{array}{r}28,15 \\
0\end{array}$ & $\begin{array}{r}103,10 \\
2\end{array}$ & $\begin{array}{r}48,53 \\
5\end{array}$ & $\begin{array}{r}42,52 \\
0\end{array}$ & $\begin{array}{r}78,20 \\
2\end{array}$ & $\begin{array}{r}56,22 \\
5\end{array}$ & $\begin{array}{r}13,13 \\
8\end{array}$ & $\begin{array}{r}58,59 \\
2\end{array}$ & $\begin{array}{r}46,14 \\
0\end{array}$ & $\begin{array}{r}55,44 \\
1\end{array}$ & $\begin{array}{r}73,91 \\
6\end{array}$ & $\begin{array}{r}62,09 \\
0\end{array}$ \\
\hline
\end{tabular}


Bad outcomes are those with no or few statistically significant coefficients with respect to transit station distance. In statistics, insignificant coefficients signify “ambiguous” relationships. Because theory requires positive associations at least to some distance from transit stations, we equate ambiguous associations with being "bad" ones. They include:

- Buffalo;

- Cleveland;

- Minneapolis-St. Paul;

- Phoenix;

- Sacramento;

- Salt Lake City; and

- Seattle.

In all, 7 of the 17 LRT systems we studied revealed ambiguous office rent premiums with respect to transit station proximity. We remind readers that our study is of market rents and not sales prices (see Chapter 20 for elaboration).

Ugly outcomes are those where there are negative, statistically significant coefficients with respect to transit station proximity. Four systems fall into this category:

Pittsburgh — the first two distance bands (to 0.25 -mile) are negative though the third (0.375-mile) is positive.

San Diego - there are negative, statistically significant coefficients extending up to 1.75 miles from LRT stations.

San Jose - that has continuously negative, statistically significant distance band coefficients to 1.25 miles.

St. Louis — where the first three distance bands, to 0.375-mile, are negative and statistically significant.

Based on theory, many of the stations comprising these systems would have such externalitiesnuisances - that the market discounts transit station proximity. While there may be design and land use planning approaches to offset negative effects of transit station proximity on office rents, they may require substantial resources or major land use decisions. 


\subsection{APPLICATIONS TO SELECTED FRT SYSTEMS}

Appendix B of this report provides visual examples of our assessment of what may be "good" and "bad" FRT station planning and design. Our criteria include:

- Whether the station is easily accessible on foot or bicycle;

- Whether it is planned into the fabric of the existing community or it is separated from it;

- Whether it is elevated (thereby compromising ease of accessibility);

- Whether it is visually attractive (though we are not experts in this criterion);

- Whether there is comfortable separation between street traffic and the FRT vehicle;

- The extent to which the station is isolated by multiple-lane highways; and

Whether passengers have to traverse parking lots to access the station unless they are parking and driving their own vehicle.

We concede that what appears to us to be "good" or "bad" planning and design may be just the opposite of experts' opinions. On the other hand, one of us (Nelson) reminds students that when they are assessing the qualities of an area for development, infill, redevelopment or related real estate activities: "You know more than you think."

When studying the Appendix, readers may be struck that occasionally what we consider a "good" or "bad" station actually has non-intuitive walk-bike-transit scores. A "good" station may have lower walk-bike-transit scores than a "bad" station. The difference is the context of the station itself. Indeed, for all LRT systems in our study, we calculated the mean walk-bike-transit scores, and their overall means, and compared the systems based on our market rent analysis to our Good-Bad-Ugly market rent typology. Results are reported in Table 8.2. Though the "Ugly" LRT systems from the perspective of market rent performance tend to be in the lower portion of the table, clear patterns using just these scores are not entirely evident. 
Table 8.2: Comparing Market Rent Typology to LRT System Mean Walk-Bike-Transit Scores from Highest to Lowest

\begin{tabular}{|c|c|c|c|c|c|}
\hline LRT System & Walk & Transit & Bike & WBT Mean & Rent Premium \\
\hline Portland & 75.1 & 71.8 & 85.5 & 77.5 & Good \\
\hline Seattle & 78.9 & 79.0 & 72.7 & 76.9 & $\mathrm{Bad}$ \\
\hline Minneapolis-St. Paul & 70.7 & 73.7 & 78.9 & 74.4 & Bad \\
\hline Buffalo & 82.9 & 64.5 & 74.6 & 74.0 & Bad \\
\hline Houston & 70.7 & 70.7 & 71.6 & 71.0 & Good \\
\hline Phoenix & 69.3 & 58.2 & 72.7 & 66.7 & $\mathrm{Bad}$ \\
\hline Sacramento & 59.2 & 52.0 & 76.4 & 62.5 & Bad \\
\hline San Diego & 67.4 & 59.7 & 59.1 & 62.1 & Ugly \\
\hline Denver & 55.0 & 60.6 & 70.3 & 62.0 & Good \\
\hline Salt Lake City & 55.5 & 62.2 & 66.8 & 61.5 & Bad \\
\hline Charlotte & 63.0 & 60.8 & 55.9 & 59.9 & Good \\
\hline San Jose & 52.7 & 52.8 & 73.8 & 59.8 & Ugly \\
\hline Dallas & 53.7 & 61.1 & 56.5 & 57.1 & Good \\
\hline Cleveland & 52.7 & 58.0 & 50.8 & 53.8 & Bad \\
\hline Norfolk & 52.5 & 53.5 & 50.7 & 52.2 & Good \\
\hline Pittsburgh & 56.3 & 60.0 & 38.4 & 51.6 & Ugly \\
\hline St. Louis & 48.0 & 50.9 & 55.5 & 51.5 & Ugly \\
\hline
\end{tabular}

Source: Analysis by authors using walk, bike and transit scores for each LRT station for each system as provided by https://www.walkscore.com/. 


\subsection{IMPLICATIONS FOR TRANSIT AND LAND USE PLANNNIG}

The purpose of this chapter was to explore reasons for differences in market rent performance reported in Chapter 2, employment performance in Chapter 3, and population and household performance in Chapter 5 in terms of FRT station proximity. As we discuss in Chapter 11, the literature and the evidence suggests that market values, economic development, and residential activities should be more than what is observed especially between areas near transit stations outward to at least 0.50 mile if not much farther.

We are impressed with overall guidelines for FRT station area planning and design advanced by the City of Vancouver, BC. Using most of their words, these " 6 Ds" of transit station planning and design are informative (TransLink 2012: 10-11):

\section{D1 Destinations}

Coordinate land use and transportation. When land use and transportation are well coordinated, transit can provide fast, direct, and cost-effective access to more destinations for more people. Transit-oriented communities coordinate land use and transportation in two important ways: At the neighborhood scale they locate most new development along reasonably direct corridors so that most destinations are 'on the way' to other destinations. At the regional scale they locate the highest densities of development and the most important destinations at the intersection of several frequent transit corridors.

\section{D2 Distance}

Create a well-connected street network A well-connected street network shortens travel distances, making it possible for people to quickly and conveniently walk or cycle to where they want to go, or to easily connect with transit en route to their destination.

\section{D3 Design}

Create places for people Transit-oriented communities are carefully designed with the needs of people in mind. Whether walking, cycling, pushing a stroller, catching a bus, or using a mobility device, people of all ages and abilities should be able to access and enjoy a comfortable, safe, delightful, and inviting public realm.

\section{D4 Density}

Concentrate and intensify activities near frequent transit Transit-oriented communities concentrate most growth and development within a short walk of frequent transit stops and stations. A higher density of homes, jobs, and other activities creates a market for transit, allowing frequent service to operate efficiently. The form of development varies from community to community based on local goals, character, and needs, and there is no 'one-sizefits-all' approach to achieving an appropriate level of density to support transit.

\section{D5 Diversity}

Encourage a mix of uses A vibrant mix of land uses helps to create complete, walkable neighborhoods around transit stations and stops, and supports a transit system that is wellutilized throughout the day. Transit-oriented communities encourage a mix of land uses at both the neighborhood and corridor scales. 


\section{D6 Demand Management}

Discourage unnecessary driving Transit-oriented communities use TDM strategies to discourage unnecessary driving and to promote walking, cycling, and transit. TDM provides incentives for travelers to shift automobile trips to other modes in a number of ways, including increasing travel options, setting appropriate prices for parking or road usage, providing information and marketing, and allocating more road space to transit, cycling, and pedestrian uses.

These concepts assume that a principal objective of FRT systems is to create communities around transit stations to at least 0.50 -mile if not 1.00 mile or more. Doing so will create agglomeration economies that advance local and regional economic development, meet at least part of the unmet demand for homes, and create places in which people want to live, work, and enjoy their leisure. It also helps assure that taxpayers receive a reasonable return on their investments.

We conclude that there does not appear to be an easy way to predict transit station development outcomes based on transit station planning and design. This is an area where new research is needed.

Chapter 9 explores another benefit of FRT systems: reducing transportation costs. 


\section{REFERENCES}

Alonso, William (1964). Location and land use: Toward a general theory of land rent. Cambridge, MA: Harvard University Press.

Boarnet, Marlon (1997). Highways and economic productivity: Interpreting recent evidence. Journal of Planning Literature 11(4): 476-486.

Boarnet, Marlon G. and Andrew F. Haughwout. (2000). Do Highways Matter? Evidence and Policy Implications of Highways Influence on Metropolitan Development. Washington, DC: The Brookings Institution, Center on Urban and Metropolitan Policy.

Bogart, William T. (1998). The Economics of Cities and Suburbs. Upper Saddle River, NJ: Prentice Hall.

Coffel, Kathryn, Jamie Parks, Conor Semler, Paul Ryus, David Sampson, Carol Kachadoorian, Herbert S. $\quad$ Levinson and Joseph L. Schofer (2012). Guidelines for Providing Access to Public Transportation Stations. Washington, DC: Transportation Research Board, Transit Cooperative Research Program.

Glaeser, Edward L. Ed (2010). Agglomeration Economics. Chicago: University of Chicago Press.

Graham, D. J. (2007). Agglomeration, productivity and transport investment. Journal of Transport Economics and Policy 41(3), September: 317-343. www.ingentaconnect.com/content/lse/jtep/2007/00000041/00000003/art00003.

Litman, Todd A. (2009). Evaluating Transportation Economic Development Impacts. Victoria, BC: Victoria Transportation Institute, http://www.vtpi.org/econ_dev.pdf.

Mills, Edwin S. (1972). Studies in the structure of the urban economy. Baltimore, MD: Johns Hopkins University Press.

Muth, Richard F. (1969). Cities and housing: The spatial structure of urban residential land use. Chicago: University of Chicago Press.

Nelson, Arthur C. and Susan J. McClesky (1990). Elevated Rapid Rail Station Impacts on Single-Family House Values, Transportation Research Record, 1266: 173-180.

Nelson, Arthur C. with John Genereux and Michelle Genereux (1992). Price Effects of Landfills on Vacant Residential Land Values. Journal of Urban Planning and Development 128-137.

Nelson, Arthur C., Geoff Anderson, Reid Ewing, Pamela Perlich, Thomas W. Sanchez, and Keith Bartholomew (2009). The Best Stimulus for the Money: Briefing Papers on the Economics of Transportation Spending. Salt Lake City: Metropolitan Research Center at the University of Utah for Smart Growth America. http://www.smartgrowthamerica.org/documents/thebeststimulus.pdf. 
Park, Robert E.; Burgess, Ernest W. (1925). The Growth of the City: An Introduction to a Research Project. The City. University of Chicago Press. pp. 47-62.

Summarized in OECD/ITF Discussion Paper 2007-11, www.internationaltransportforum.org/jtrc/DiscussionPapers/DiscussionPaper11.pdf.

TransLink (2012). Transit-Oriented Communities Design Guidelines: Creating more livable places around transit in Metro Vancouver. Burnaby BC: TransLink Strategic Planning and Policy.

Weisbrod, Glen, Derek Cuter and Chandler Duncan (2013). The Role of Transit in Support of High Growth Business Clusters in the U.S. Washington, DC: American Public Transit Association 


\subsection{THE LINK BETWEEN HOUSEHOLD TRANSPORTATION COST AND TRANSIT STATION PROXIMITY}

\subsection{OVERVIEW}

It seems an article of faith that transportation costs as a share of household income increase with respect to distance from downtowns, freeway interchanges, and light rail transit stations. Considerable literature reports price effects of these points on residential property values but none measure explicitly differences in household transportation costs as a share of household budgets. Our study helps close this gap in literature. Using the U.S. Department of Housing and Urban Development's (HUD) Location Affordability Index (LAI) database, which estimates the share of household budgets consumed by transportation at the block group level based on the 2012 5-year American Community Survey (ACS) and census tracts based on the 2016 5-year ACS. We evaluate the association between median household transportation costs and distance from light rail transit (LRT), bus rapid transit (BRT) and streetcar transit (SCT) stations using both ACS data sets. (We exclude commuter rail transit because its service schedules are less frequent than the other systems.) We find clear associations between transit station proximity and lower household transportations for both periods, with what appears to be increasing savings over time. We offer implications for transit and land use planning and housing, as well as for future research.

\subsection{INTRODUCTION AND LITERATURE REVIEW}

Conventional theory of location and land-use, especially residential location, in post-World War II, automobile dominant American metropolitan areas has household demand for location as a function of income, household size, and location costs - that is, the transportation costs associated with accessing work, shopping, services, recreation and other purposes from a prospective home. House and lot size increased the farther from centers one went. At some point, a household achieved equilibrium where preference for housing and neighborhood attributes were maximized given location costs. Conventional models of location and land-use decisions (see Alonso-Muth-Mills), however, did not consider lenders' underwriting standards which often capped principal-interest-taxes-insurance payments at 28 percent of the household's income available to service a mortgage.

By failing to consider location costs in the mortgage underwriting decision, lenders induce households to purchase homes farther away from centers than they may have chosen otherwise, resulting in more land-extensive development patterns across America's metropolitan landscapes. Combined with the ability to deduct mortgage interest against taxable income, the practice in most states to under-value owner-occupied homes for property tax assessment purposes, average-cost pricing of utility services resulting in high-cost areas paying less than their costs with low-cost areas paying more, and heavily subsidized highway investments among other actions (Blais 2010) led to inefficient land-use patterns. Some call it sprawl. 
In recent years a growing body of literature has argued that housing and transportation costs need to be considered together when considering housing affordability.15 Ewing and Hamidi (2015) note that HUD's definition of affordability-where no more than 30 percent of a household's income would be spent on housing - along with indexes of others are "structurally flawed in that they only consider costs directly related to housing, ignoring those related to utilities and transportation” (Ewing and Hamidi: 5). The 2013 Consumer Expenditure Survey, for instance, reports that total housing costs consume 33.6 percent of income 16 while transportation costs consume another 17.6 percent for a total $\mathrm{H}+\mathrm{T}$ of 51.2 percent. If a household's transportation costs could be reduced by half, however, it would not able to acquire a home mortgage for a more expensive home in a more efficient location that capitalizes the savings even though it would not be economically worse off.

Conceptually, transportation cost savings are realized by locating in or near such places as downtowns, mixed-use developments, and transit stations. Studies only estimate these savings in two ways. First, a suite of studies based on work by the Center for Neighborhood Technology uses secondary data to estimate the share of trips by mode and household type at the block group, and then derive vehicle miles traveled through inferences based on other secondary data. The actual distance from block groups to such points as downtowns and transit is not estimated directly.17 For several household types, CNT's studies estimate housing costs that are constant across large geographies such as counties while transportation costs vary by block group.

Another set of studies use hedonic regression analysis to estimate the variation in real estate values with respect to distance from such points as the downtown center and transit stations. Higgins' and Kanaroglou's (2015) review of 40 years of literature on market responsiveness to transit investment provide a thorough review of the models, methods, and outcomes using this technique. Transportation costs per se are not included in any of those studies.

We know of no research that estimates variation in transportation costs spatially.18 Our study helps close this gap. Our particular interest is in knowing whether and the extent to which proximity to transit stations affects the share of transportation costs incurred by households, and whether those savings increase over time. If so, the finding may help explain part of the

15 We refer readers to HUD’s Location Affordability Portal for literature and other materials on the concept of housing plus transportation ("H+T") costs (see http://www.locationaffordability.info/).

16 These costs include "shelter" components such as rent and mortgage, utilities, insurance, maintenance and repairs, and several other expenditures. See http://www.bls.gov/cex/2013/combined/income.pdf.

17 CNT has produced two significant generations of these studies. The first is reported in http://htaindex.cnt.org/map/ and the second in http://www.locationaffordability.info/default.aspx.

18 Specifically, we do not know of any study that estimates the slope of change in the share of $\mathrm{HH}$ income consumed by transportation with respect to downtown or transit stations. 
capitalization effect numerous studies find with respect to residential property values and rents. It may also add new information to the discussion on the relationship between housing affordability and transportation costs as a function of transit station proximity. In establishing this relationship, we will also explore similar relationships with respect to distance from downtown and freeway interchanges.

We begin with a discussion of our analytic approach, model, and data. We then report results and interpretations. We finish this chapter with implications for transit and land use planning.

\subsection{RESEARCH QUESTION AND DESIGN}

Our research question is:

\section{Do transportation costs as a share of median household incline decline with respect to light rail transit station proximity controlling for other factors?}

The research question lends itself to quasi-experimental, cross-section analysis at a given point in time. Our aim is to measure the variation in household transportation costs with respect to distance from LRT, BRT and SCT transit stations. Fortunately, HUD's Location Affordability Index (LAI) includes data we need for this analysis. The LAI estimates household housing and transportation costs at the neighborhood level based on eight household prototypes. HUD's motivation for advancing discussion of location affordability is summarized as follows:

The prevailing standard of affordability in the United States is paying 30 percent or less of your family's income on housing, but this fails to account for transportation costs. One reason is that transportation costs have grown significantly as a proportion of household income since this standard was established. According to the Bureau of Labor Statistics, in the 1930's American households spent just 8 percent of their income on transportation. Since then, as a substantial proportion of the U.S. population has migrated from center cities to surrounding suburbs and exurbs and come to rely more heavily (or exclusively) on cars, that percentage has steadily increased, peaking at 19.1 percent in 2003. As of 2013, households spent on average about 17 percent of their annual income on transportation, second only to housing costs in terms of budget impact. And for many working-class and rural households, transportation costs actually exceed housing costs.19

HUD has produced three versions though Version 2 and Version 3 are considered the most compatible. Version 2 is based on census block groups applied to the 2012 5-year ACS while Version 3 is based on census tracts applied to the 2016 5-year ACS. Among the eight household types for which estimates are provided, we use figures for the "regional typical" household.20 In effect, each of the household types is a composite of all households in the census block group

19 https://www.hudexchange.info/programs/location-affordability-index/about/

20 For details of both versions, see https://www.hudexchange.info/programs/locationaffordability-index/ 
(CBG) in Version 2 and central tract (CT) in Version 3. As such, these composite or index measures inherently include income, race/ethnicity, education, and other socioeconomic constructs. These household prototypes vary based on transportation costs as a share of median regional household income for the regional typical household by CBG or CT. In turn, these household transportation costs are based on simultaneous equation models using a variety of federal data sources.

As no database provides estimates of household transportation costs disaggregated to the CBG or CT levels, and as disaggregation is needed to address the research question, we choose to use the LAI for our analysis. We apply our analysis to those systems we have evaluated throughout this report, including 17 LRT systems, 13 BRT systems and 9 SCT systems (see Table 9.1). All these systems were operating at the time of the 2016 5-year ACS while nearly all were operating concurrent with the 2012 5-year ACS.

We use the standard-form ordinary least squares regression model adapted for our purposes:

Regional Typical Household Transportation Cost Share $=\boldsymbol{f}$ (Location, Metropolitan Controls, FTR proximity)

Where

Regional Typical Household Transportation Cost Share is the dependent variable. It is defined as the median household transportation cost divided by median household income at the CBG or CT for the 2012 5-year ACS or 2016 5-year ACS, respectively. Because "regional typical households" are themselves an index, they inherently include socioeconomic factors.

Location means distance to the central business district (DCBD), based on our Google map assessment of the highest value intersection and distance to nearest freeway intersection (DFreeway).

The experimental variable is the distance from the nearest transit station to the CBG or CT. For reasons explained in Chapter 2, we use $\mathbf{0 . 1 2 5}$-mile distance bands to $\mathbf{2 . 0 0}$ miles; thus, all coefficients are interpreted in comparison to all cases beyond 2 miles.

To account for variation attributable to structural differences between metropolitan areas, we include Metropolitan Controls.

We present results next followed by implications for transit and land use planning. 
Table 9.1: FTR Systems Used in Analysis

\begin{tabular}{l|l|l|l|l|l}
\hline Light Rail Transit & Year & Bus Rapid Transit & Year & Streetcar Transit & Year \\
\hline Buffalo & 1984 & Cleveland & 2008 & Atlanta & 2014 \\
\hline Charlotte & 2007 & Eugene-Springfield & 2007 & Dallas & 2015 \\
\hline Cleveland & 1980 & Kansas City & 2005 & Little Rock & 2004 \\
\hline Dallas & 1996 & Las Vegas & 2004 & Portland & 2001 \\
\hline Denver & 1994 & Nashville & 2009 & Salt Lake City & 2013 \\
\hline Houston & 2004 & Phoenix & 2009 & Seattle & 2007 \\
\hline Minn.-St. Paul & 2004 & Pittsburgh & 1977 & Tacoma & 2003 \\
\hline Norfolk & 2011 & Reno & 2010 & Tampa & 2002 \\
\hline Phoenix & 2008 & Salt Lake City & 2008 & Tucson & 2014 \\
\hline Pittsburgh & 1984 & San Antonio & 2012 & & \\
\hline Portland & 1986 & San Diego & 2014 & & \\
\hline Sacramento & 1987 & Seattle & 2010 & & \\
\hline Salt Lake City & 1999 & Stockton & 2007 & & \\
\hline San Diego & 1981 & & & & \\
\hline San Jose & 1987 & & & & \\
\hline Seattle & 2003 & & & & \\
\hline St. Louis & 1993 & & & & \\
\hline
\end{tabular}

\subsection{RESULTS}

Tables 9.2 through 9.4 report our regression results for LRT, BRT and SCT systems, respectively. The models perform reasonably well with coefficients of determination ranging in the middle 30\% for the CBG analysis and close to 20\% for the CT analysis-the lower CT explanations may be attributable to using larger geographies in 2016 (CTs). The F-ratios are all quite large. The correlation matrix does not show any problematic collinearity. As expected, as proximity to transit stations improves, household transportation costs fall. But there are important nuances.

We adjust the regression coefficients to reflect the share of the regional typical household budget savings with respect to transit station proximity. This is simply the coefficient for a given distance band multiplied by the mean household transportation cost for those households as a whole. For instance, for LRT systems in the 2012 5-year ACS in the first (0.125-mile) distance band, the coefficient is $-16.2 \%$. Multiplying this by the mean household transportation budget of $21.0 \%$ means that there is an overall savings of 3.6\% for households living in this distance band. Table 9.5 makes these calculations. Figures 9.1 through 9.3 illustrate trends.

In the figures, we note that lines for 2016 5-year ACS are less smooth than for the 2012 5-year ACS. The reason is the difference in geography where 2016 is based on coarse CTs while the 2012 geography is the more fine-gained CBGs.

For LRT systems, the typical regional households budget improved by an order of about one-half of one percent between 2012 and 2016 when considering transit station proximity. But for BRT systems, the improvement was more than one percent (or roughly a $25 \%$ increase in savings). In contrast, there was not no discernable change in savings associated with SCT station proximity between 2012 and 2016. 
We observe that for the most part, there was only a nominal change in the number of LRT and BRT systems between 2012 and 2016-the San Diego BRT system was added in 2014, though San Antonio was added in 2012. The implication is that as systems mature and markets have time to respond to FRT systems, there may be some marginal shifting of residential development accordingly. This must not be over-stated however, as the household budget savings while not trivial are also not very large.

We turn next to implications for transit and land use planning.

Table 9.2: The Association between Transit Station Proximity and Typical Regional Household Transportation Costs as a Percent of Regional Median Household Income, Light Rail Systems

\begin{tabular}{l|r|r}
\hline Variable & 2012 5-Yr ACS & 2016 5-Yr ACS \\
\hline Constant & 3.036 & 3.071 \\
\hline DCBD & $-1.323 \mathrm{E}-007$ & $4.373 \mathrm{E}-008$ \\
\hline DFreeway & $4.513 \mathrm{E}-006$ & $5.314 \mathrm{E}-006$ \\
\hline $\mathbf{0 . 1 2 5}$ & $-16.2 \%$ & $-15.7 \%$ \\
\hline $\mathbf{0 . 2 5}$ & $-15.0 \%$ & $-14.6 \%$ \\
\hline $\mathbf{0 . 3 7 5}$ & $-14.5 \%$ & $-15.0 \%$ \\
\hline $\mathbf{0 . 5 0}$ & $-13.3 \%$ & $-13.2 \%$ \\
\hline $\mathbf{0 . 6 2 5}$ & $-12.7 \%$ & $-12.9 \%$ \\
\hline $\mathbf{0 . 7 5}$ & $-11.4 \%$ & $-11.0 \%$ \\
\hline $\mathbf{0 . 8 7 5}$ & $-10.9 \%$ & $-12.8 \%$ \\
\hline $\mathbf{1 . 0 0}$ & $-10.5 \%$ & $-9.7 \%$ \\
\hline $\mathbf{1 . 1 2 5}$ & $-10.5 \%$ & $-10.6 \%$ \\
\hline $\mathbf{1 . 2 5}$ & $-9.6 \%$ & $-12.0 \%$ \\
\hline $\mathbf{1 . 3 7 5}$ & $-8.8 \%$ & $-10.3 \%$ \\
\hline $\mathbf{1 . 5 0}$ & $-8.9 \%$ & $-8.2 \%$ \\
\hline $\mathbf{1 . 6 2 5}$ & $-9.5 \%$ & $-9.6 \%$ \\
\hline $\mathbf{1 . 7 5}$ & $-8.9 \%$ & $-8.9 \%$ \\
\hline $\mathbf{1 . 8 7 5}$ & $-8.9 \%$ & $-8.4 \%$ \\
\hline $\mathbf{2 . 0 0}$ & $-8.6 \%$ & $-8.0 \%$ \\
\hline Buffalo & 0.172 & 0.257 \\
\hline Charlotte & 0.078 & 0.210 \\
\hline Cleveland & 0.140 & 0.260 \\
\hline Denver & -0.020 & 0.053 \\
\hline Houston & -0.053 & 0.042 \\
\hline Minneapolis & -0.101 & -0.032 \\
\hline Phoenix & 0.084 & 0.156 \\
\hline Pittsburgh & 0.129 & 0.180 \\
\hline Portland & 0.077 & 0.097 \\
\hline Sacramento & 0.054 & 0.129 \\
\hline Salt Lake City & 0.065 & 0.119 \\
\hline San Diego & 0.016 & 0.083 \\
\hline San Jose & -0.297 & -0.306 \\
\hline Seattle & -0.086 & -0.081 \\
\hline St. Louis & 0.087 & 0.192 \\
\hline & & \\
\hline & & \\
\hline
\end{tabular}


Table 9.2: The Association between Transit Station Proximity and Typical Regional Household Transportation Costs as a Percent of Regional Median Household Income, Light Rail Systems—continued

\begin{tabular}{l|r|r}
\hline Variable & 2012 5-Yr ACS & 2016 5-Yr ACS \\
Model Performance \\
\hline Cases & $\mathbf{5 0 1 0 3}$ & $\mathbf{3 5 5 8 4}$ \\
\hline Adj. R-squared & 0.322 & 0.151 \\
\hline F-ratio & 680.303 & 187.056 \\
\hline Mean HH T Ratio & $21.0 \%$ & $23.2 \%$ \\
\hline
\end{tabular}


Table 9.3: The Association between Transit Station Proximity and Typical Regional Household Transportation Costs as a Percent of Regional Median Household Income, Bus Rapid Transit Systems

\begin{tabular}{l|r|r}
\hline Variable & 2012 5-Yr ACS & 2016 5-Yr ACS \\
\hline Constant & 2.929 & 3.06 \\
\hline DCBD & $-4.188 \mathrm{E}-008$ & $5.236 \mathrm{E}-008$ \\
\hline DFreeway & $5.076 \mathrm{E}-006$ & $5.32 \mathrm{E}-006$ \\
\hline $\mathbf{0 . 1 2 5}$ & $-19.4 \%$ & $-22.4 \%$ \\
\hline $\mathbf{0 . 2 5}$ & $-17.8 \%$ & $-23.8 \%$ \\
\hline $\mathbf{0 . 3 7 5}$ & $-15.7 \%$ & $-20.4 \%$ \\
\hline $\mathbf{0 . 5 0}$ & $-13.6 \%$ & $-20.8 \%$ \\
\hline $\mathbf{0 . 6 2 5}$ & $-14.5 \%$ & $-18.8 \%$ \\
\hline $\mathbf{0 . 7 5}$ & $-11.3 \%$ & $-18.0 \%$ \\
\hline $\mathbf{0 . 8 7 5}$ & $-12.5 \%$ & $-16.3 \%$ \\
\hline $\mathbf{1 . 0 0}$ & $-10.0 \%$ & $-15.8 \%$ \\
\hline $\mathbf{1 . 1 2 5}$ & $-8.3 \%$ & $-10.8 \%$ \\
\hline $\mathbf{1 . 2 5}$ & $-8.5 \%$ & $-13.0 \%$ \\
\hline $\mathbf{1 . 3 7 5}$ & $-8.0 \%$ & $-14.2 \%$ \\
\hline $\mathbf{1 . 5 0}$ & $-9.1 \%$ & $-14.0 \%$ \\
\hline $\mathbf{1 . 6 2 5}$ & $-5.7 \%$ & $-9.5 \%$ \\
\hline $\mathbf{1 . 7 5}$ & $-7.6 \%$ & $-12.8 \%$ \\
\hline $\mathbf{1 . 8 7 5}$ & $-7.0 \%$ & $-10.9 \%$ \\
\hline $\mathbf{2 . 0 0}$ & $-6.0 \%$ & $-10.6 \%$ \\
\hline Albuquerque & 0.286 & 0.391 \\
\hline Cleveland & 0.235 & 0.277 \\
\hline Eugene-Springfield & 0.420 & 0.404 \\
\hline Kansas City & 0.177 & 0.217 \\
\hline Las Vegas & 0.227 & 0.305 \\
\hline Minneapolis-St. Paul & -0.021 & -0.037 \\
\hline Nashville & 0.261 & 0.315 \\
\hline Phoenix & 0.176 & 0.182 \\
\hline Pittsburgh & 0.307 & 0.329 \\
\hline Reno & 0.222 & 0.256 \\
\hline Salt Lake City & 0.108 & 0.081 \\
\hline San Antonio & 0.227 & 0.255 \\
\hline San Diego & 0.087 & 0.082 \\
\hline & & \\
\hline & & \\
\hline
\end{tabular}

Table 9.3: The Association between Transit Station Proximity and Typical Regional Household Transportation Costs as a Percent of Regional Median Household Income, Bus Rapid Transit Systemscontinued

\begin{tabular}{l|r|r}
\hline \multicolumn{1}{|c|}{ Variable } & 2012 5-Yr ACS & 2016 5-Yr ACS \\
\hline Model Performance & \multicolumn{2}{c}{} \\
\hline San Jose & $\mathbf{- 0 . 2 0 5}$ & $\mathbf{- 0 . 2 8 3}$ \\
\hline Seattle & 0.075 & 0.031 \\
\hline Stockton & 0.278 & 0.310 \\
\hline Washington & -0.359 & -0.392 \\
\hline Cases & 35,561 & 35,584 \\
\hline Adj. R-squared & 0.352 & 0.180 \\
\hline F-ratio & 552.425 & 224.556 \\
\hline Mean HH T Ratio & $20.6 \%$ & $23.2 \%$ \\
\hline
\end{tabular}


Table 9.3: The Association between Transit Station Proximity and Typical Regional Household Transportation Costs as a Percent of Regional Median Household Income, Streetcar Transit Systems

\begin{tabular}{l|r|r}
\hline Variable & 2012 5-Yr ACS & 2016 5-Yr ACS \\
\hline Constant & 2.964 & 3.07 \\
\hline DCBD & $-1.172 \mathrm{E}-008$ & $2.402 \mathrm{E}-008$ \\
\hline DFreeway & $5.172 \mathrm{E}-006$ & $5.423 \mathrm{E}-006$ \\
\hline $\mathbf{0 . 1 2 5}$ & $-20.5 \%$ & -0.208 \\
\hline $\mathbf{0 . 2 5}$ & $-21.7 \%$ & -0.204 \\
\hline $\mathbf{0 . 3 7 5}$ & $-18.9 \%$ & -0.188 \\
\hline $\mathbf{0 . 5 0}$ & $-18.6 \%$ & -0.156 \\
\hline $\mathbf{0 . 6 2 5}$ & $-16.9 \%$ & -0.17 \\
\hline $\mathbf{0 . 7 5}$ & $-12.1 \%$ & -0.098 \\
\hline $\mathbf{0 . 8 7 5}$ & $-13.1 \%$ & -0.097 \\
\hline $\mathbf{1 . 0 0}$ & $-12.3 \%$ & -0.112 \\
\hline $\mathbf{1 . 1 2 5}$ & $-11.7 \%$ & -0.114 \\
\hline $\mathbf{1 . 2 5}$ & $-10.1 \%$ & -0.092 \\
\hline $\mathbf{1 . 3 7 5}$ & $-9.8 \%$ & -0.098 \\
\hline $\mathbf{1 . 5 0}$ & $-7.4 \%$ & -0.07 \\
\hline $\mathbf{1 . 6 2 5}$ & $-10.5 \%$ & -0.091 \\
\hline $\mathbf{1 . 7 5}$ & $-6.7 \%$ & -0.05 \\
\hline $\mathbf{1 . 8 7 5}$ & $-8.0 \%$ & -0.069 \\
\hline $\mathbf{2 . 0 0}$ & $-8.0 \%$ & -0.068 \\
\hline Atlanta & 0.042 & 0.095 \\
\hline Cincinnati & 0.111 & 0.178 \\
\hline Dallas & 0.097 & 0.024 \\
\hline Kansas & 0.257 & 0.137 \\
\hline Little Rock & 0.226 & 0.325 \\
\hline New Orleans & 0.059 & 0.289 \\
\hline Portland & 0.068 & 0.008 \\
\hline Salt Lake City & 0.231 & 0.048 \\
\hline Seattle & 0.226 & -0.093 \\
\hline Tampa & -0.439 & 0.286 \\
\hline Tucson & 0.194 & 0.272 \\
\hline Cases & 103,314 & 35,584 \\
\hline Adj. R-squared & 0.156 & 0.134 \\
\hline F-ratio & 682.258 & 178.012 \\
\hline Mean HH T Ratio & $20.7 \%$ & $23.2 \%$ \\
\hline & & \\
\hline & & \\
\hline
\end{tabular}


Table 9.4: Regional Typical Household Budget Savings with Respect to LRT, BRT and SCT Station Proximity

\begin{tabular}{|c|c|c|c|c|c|c|}
\hline \multirow[b]{2}{*}{ Distance Band } & \multicolumn{2}{|c|}{ Light Rail Transit } & \multicolumn{2}{|c|}{ Bus Rapid Transit } & \multicolumn{2}{|c|}{ Streetcar Transit } \\
\hline & $\begin{array}{c}\text { Median HH } \\
\text { Budget Difference } \\
\text { from Mean } 2012 \\
\text { 5-Year ACS }\end{array}$ & $\begin{array}{c}\text { Median HH } \\
\text { Budget Difference } \\
\text { from Mean } 2016 \\
\text { 5-Year ACS }\end{array}$ & $\begin{array}{c}\text { Median HH } \\
\text { Budget Difference } \\
\text { from Mean } 2012 \\
\text { 5-Year ACS }\end{array}$ & $\begin{array}{c}\text { Median HH } \\
\text { Budget Difference } \\
\text { from Mean } 2016 \\
\text { 5-Year ACS }\end{array}$ & $\begin{array}{c}\text { Median HH } \\
\text { Budget Difference } \\
\text { from Mean } 2012 \\
\text { 5-Year ACS }\end{array}$ & $\begin{array}{c}\text { Median HH } \\
\text { Budget Difference } \\
\text { from Mean } 2016 \\
\text { 5-Year ACS }\end{array}$ \\
\hline 0.125 & $-3.4 \%$ & $-3.6 \%$ & $-4.0 \%$ & $-5.2 \%$ & $-4.3 \%$ & $-4.8 \%$ \\
\hline 0.250 & $-3.1 \%$ & $-3.4 \%$ & $-3.6 \%$ & $-5.5 \%$ & $-4.5 \%$ & $-4.7 \%$ \\
\hline 0.375 & $-3.0 \%$ & $-3.5 \%$ & $-3.2 \%$ & $-4.7 \%$ & $-3.9 \%$ & $-4.4 \%$ \\
\hline 0.500 & $-2.8 \%$ & $-3.1 \%$ & $-2.8 \%$ & $-4.8 \%$ & $-3.9 \%$ & $-3.6 \%$ \\
\hline 0.625 & $-2.7 \%$ & $-3.0 \%$ & $-3.0 \%$ & $-4.4 \%$ & $-3.5 \%$ & $-3.9 \%$ \\
\hline 0.750 & $-2.4 \%$ & $-2.6 \%$ & $-2.4 \%$ & $-4.2 \%$ & $-2.5 \%$ & $-2.3 \%$ \\
\hline 0.875 & $-2.3 \%$ & $-3.0 \%$ & $-2.7 \%$ & $-3.8 \%$ & $-2.7 \%$ & $-2.3 \%$ \\
\hline 0.100 & $-2.2 \%$ & $-2.3 \%$ & $-1.8 \%$ & $-3.7 \%$ & $-2.6 \%$ & $-2.6 \%$ \\
\hline 1.125 & $-2.2 \%$ & $-2.5 \%$ & $-1.8 \%$ & $-2.5 \%$ & $-2.4 \%$ & $-2.6 \%$ \\
\hline 1.250 & $-2.0 \%$ & $-2.8 \%$ & $-1.7 \%$ & $-3.0 \%$ & $-2.1 \%$ & $-2.1 \%$ \\
\hline 1.375 & $-1.8 \%$ & $-2.4 \%$ & $-1.9 \%$ & $-3.3 \%$ & $-2.0 \%$ & $-2.3 \%$ \\
\hline 1.500 & $-1.9 \%$ & $-1.9 \%$ & $-1.2 \%$ & $-3.3 \%$ & $-1.5 \%$ & $-1.6 \%$ \\
\hline 1.625 & $-2.0 \%$ & $-2.2 \%$ & $-1.4 \%$ & $-2.2 \%$ & $-2.2 \%$ & $-2.1 \%$ \\
\hline 1.750 & $-1.9 \%$ & $-2.1 \%$ & $-1.5 \%$ & $-3.0 \%$ & $-1.4 \%$ & $-1.2 \%$ \\
\hline 1.875 & $-1.9 \%$ & $-2.0 \%$ & $-1.4 \%$ & $-2.5 \%$ & $-1.7 \%$ & $-1.6 \%$ \\
\hline 2.000 & $-1.8 \%$ & $-1.9 \%$ & $-1.2 \%$ & $-2.5 \%$ & $-1.7 \%$ & $-1.6 \%$ \\
\hline
\end{tabular}




\section{Light Rail Transit}

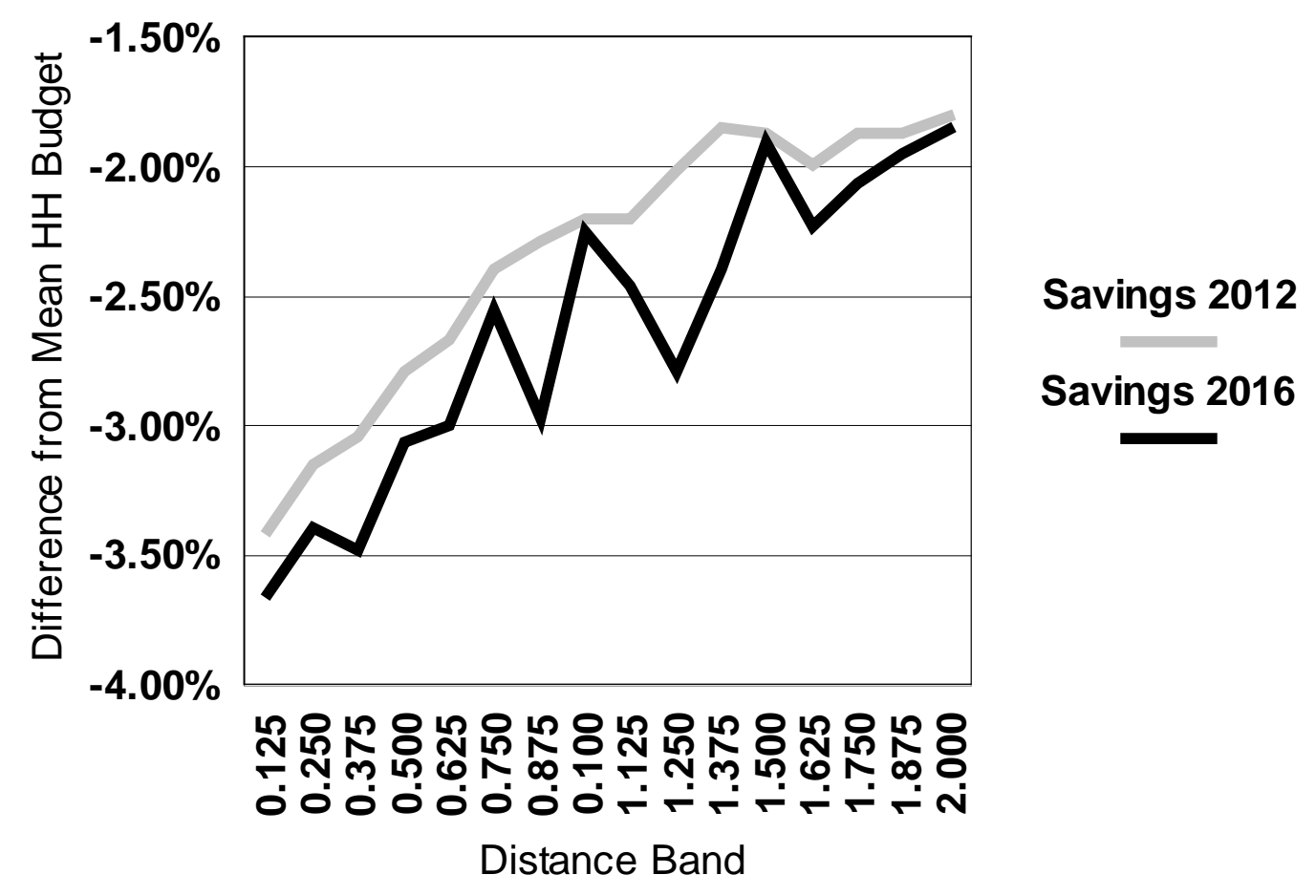

Figure 9.1: Illustration of the Association between Transit Station Proximity and Typical Regional Household Transportation Costs as a Percent of Regional Median Household Income, Light Rail Systems 


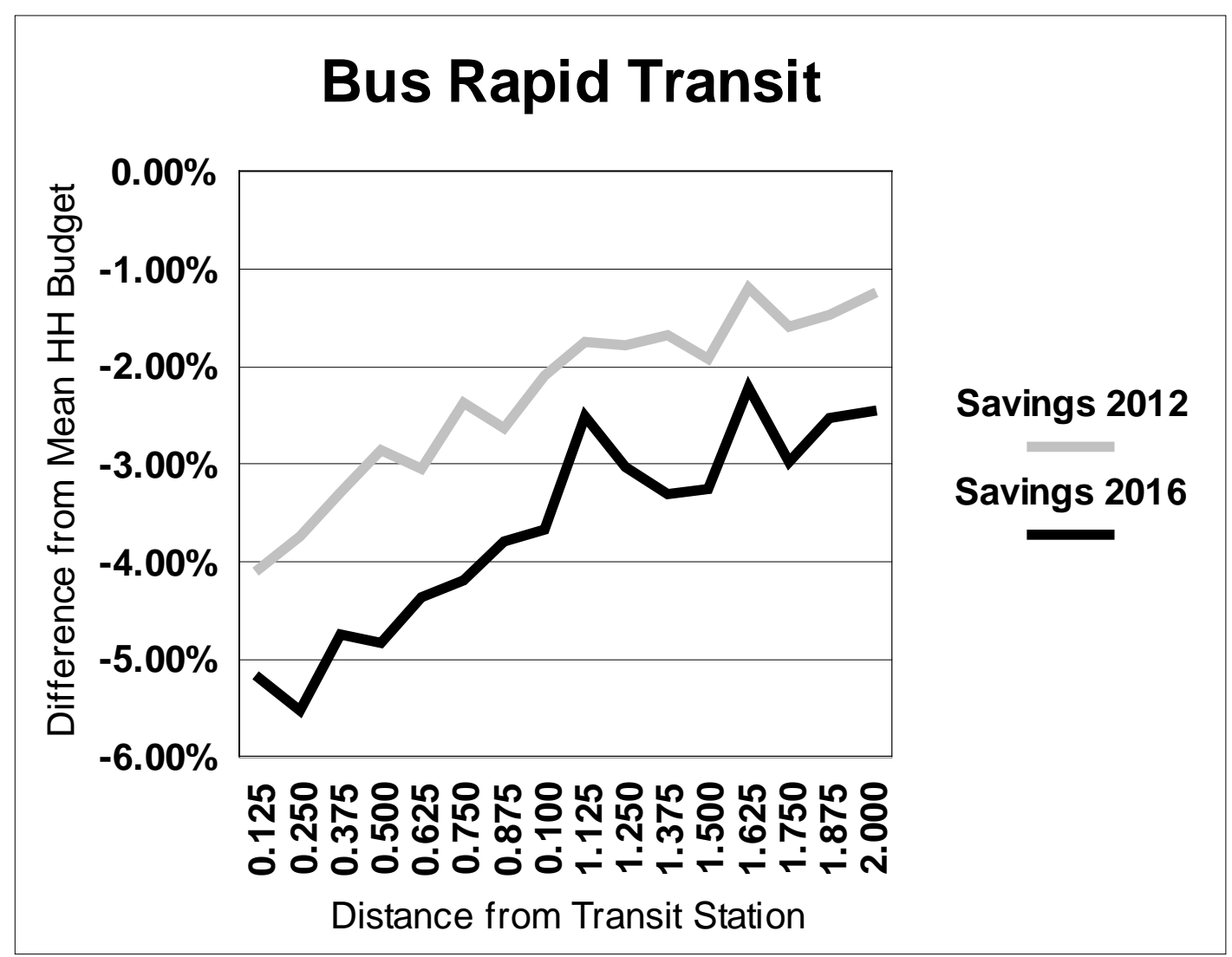

Figure 9.2: Illustration of the Association between Transit Station Proximity and Typical Regional Household Transportation Costs as a Percent of Regional Median Household Income, Bus Rapid Transit Systems 


\section{Streetcar Transit}

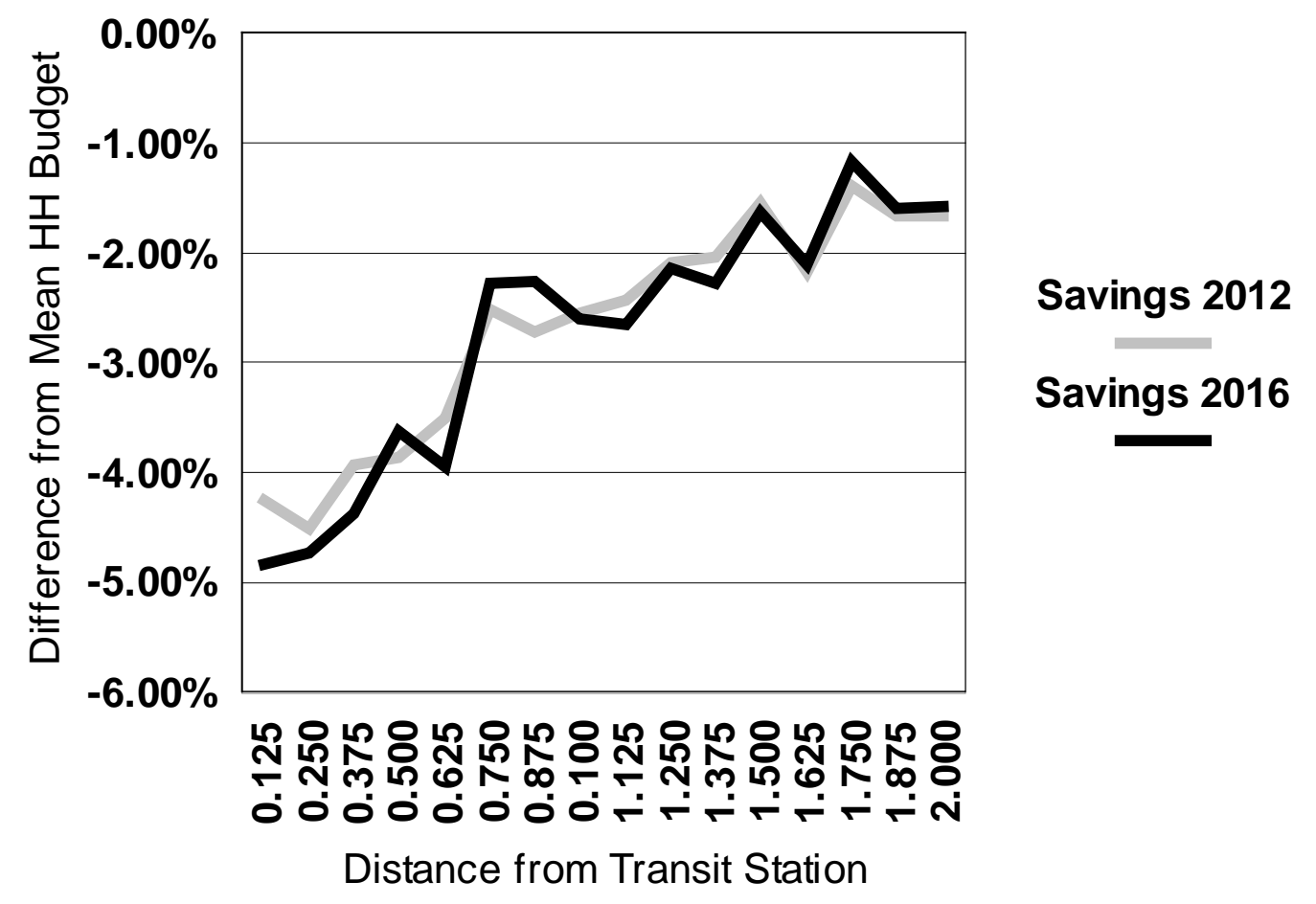

Figure 9.3: Illustration of the Association between Transit Station Proximity and Typical Regional Household Transportation Costs as a Percent of Regional Median Household Income, Streetcar Transit Systems 


\subsection{IMPLICATIONS FOR TRANSIT AND LAND USE PLANNING}

That households' share of income devoted to transportation increases with respect to LRT stations to about seven miles elicits two important policy implications from us.

First, our findings may be used to relax early efforts to calibrate location-efficient mortgages (LEM). For the most part, the LEM calculations were weighted substantially toward the central business district. Considering just this limitation, research by Blackman and Krupnick (2001) conclude that LEMs do not raise mortgage default rates and should be weighed against antisprawl benefits they may offer. We suspect default rates will be lower the closer properties are to LRT stations. Further research may explore the relationship between proximity to LRT stations if not all fixed guideway transit stations and foreclosure rates. 21

Second, assumptions about planning land uses around FRT stations may need to be relaxed. The so-called half-mile circle planning area has coming under increasing challenge with studiesincluding our own (see also Petheram 2013, Nelson et al. 2015, Nelson and Hibberd 2019) showing market responsiveness transit station proximity up to 2 miles. Our empirical analysis suggests that FRT station planning protocols may need to extend many miles from stations.

The nation will add about 100 million people between now and mid-century. One of us (Nelson 2013) has estimated that about a quarter of American households want to live near fixed guideway transit opportunities though less than 10 percent have those options now. Perhaps one reason is that Americans understand the cost savings associated with living near transit stations. Yet, even if all new homes built between now and mid-century were located near existing or planned fixed-guideway transit stations the demand for living near those stations would still not be met.

21 We conducted an indirect test of this is using our data through a bivariate regression where Vacancy Rate (VR) as a proxy for foreclosure potential is a function of LRT station distance: VR $=10.344+$ LRT-Station-Distance*-0.626, $\mathrm{p}<0.001$. 


\section{REFERENCES}

Alonso, William (1964). Location and Land Use: Toward a General Theory of Land Rent. Cambridge, MA: Harvard University Press.

Blackman, Allen and Alan Krupnick (2001). Location Efficient Mortgages: Is the Rationale Sound? Baltimore, MD: Resources for the Future.

Pamela Blais (2010). Perverse Cities: Hidden Subsidies, Wonky Policy, and Urban Sprawl. Vancouver, BC: University of British Columbia.

Center for Housing Policy (2006). A Heavy Load: The Combined Housing and Transportation Burdens of Working Families. Washington, DC: Center for Housing Policy

Emrath, Paul and Natalia Siniavskaia (2009). Household Type, Housing Choice, and Commuting Behavior. Washington, DC: National Association of Home Builders.

Ewing, Reid and Shima Hamidi (2015). How Affordable is HUD Affordable Housing? Portland, OR: Portland State University, National Institute for Transportation and Communities.

Fan, Yingling and Arthur Huang (2012). How Affordable is Transportation? A Context-Sensitive Framework. Minneapolis, MN: University of Minnesota, Humphrey School of Public Affairs.

Gallagher, Leigh (2014). The End of the Suburbs. New York, NY: Portfolio

Galster, George and Jackie Cutsinger (2007). Racial Settlement and Metropolitan Land Use Patterns: Does Sprawl Abet Black-White Segregation? Urban Geography 28(6): 515-553.

Haas, Peter M., Carrie Makarewicz, Albert Benedict, and Scott Bernstein (2008). Estimating Transportation Costs by Characteristics of Neighborhood and Household. Transportation Research Record: Journal of the Transportation Research Board, 2077: 62-70.

Hicky, Robert, Jeffrey Lubell, Peter Haas, Stephanie Morse (2012). Losing Ground: The Struggle of Moderate-Income Households to Afford the Rising Costs of Housing and Transportation. Washington, DC: Center for Housing Policy and Chicago, IL: Center for Neighborhood Technology.

Higgins, Christopher D. and Pavlos S. Kanaroglou (2015). 40 Years of Modelling Rail Transit's Land Value Uplift in North America: Diverse Methods, Differentiated Outcomes, Debatable Assumptions, and Future Directions. Transportation Research Record (forthcoming).

Mills, Edwin S. (1967). An Aggregative Model of Resource Allocation in a Metropolitan Area. American Economic Review (Papers and Proceedings) 57(2):197-210.

Muth, Richard F. 1969. Cities and Housing. Chicago: University of Chicago Press.

Nelson, Arthur C., Dejan Eskic, Shima Hamidi, Susan J. Petheram, Reid Ewing, Jenny H. Liu (2015). Office Rent Premiums with Respect to Light Rail Transit Stations: Case Study of Dallas 
with Implications for TOD Planning. Transportation Research Record: Journal of the Transportation Research Board (forthcoming).

Nelson, Arthur C., Gail Meakins, Deanne Eeber, Shyam Kannan, Reid Ewing (2013). The Tragedy of the Unmet Demand for Walking and Biking. The Urban Lawyer. 45(3): 615-630.

Petheram, Susan J., Arthur C. Nelson, Matt Miller, and Reid Ewing (2013). Use of the Real Estate Market to Establish Light Rail Station Catchment Areas Case Study of Attached Residential Property Values in Salt Lake County, Utah, by Light Rail Station Distance.

Transportation Research Record: Journal of the Transportation Research Board, 2357: 95-99.

Redding, Stephen J. and Matthew A. Turner (2014). Transportation Costs and the Spatial Organization of Economic Activity. National Bureau of Economic Research Work Paper 20235. Cambridge, MA: National Bureau of Economic Research.

Reichenberger, Adam (2012). A comparison of 25 years of consumer expenditures by homeowners and renters. Beyond the Numbers 1(15): 1-8.

Stoker, Philip and Reid Ewing (2014). Job-Worker Balance and Income Match in the United States. Housing Policy Debate 24 (2): 485-497. 


\subsection{THE (OVERLOOKED) LINK BETWEEN EXPRESS BUS STATIONS AND COMMERCIAL RENTS WITH IMPLICATIONS FOR TRANSIT AND LAND USE PLANNING}

\subsection{OVERVIEW}

This is the first study establishing the association between express bus transit (XBT) stations and commercial office, apartment and retail rents. Nearly if not all research reporting the association between transit and real estate values focuses on heavy rail (also called third rail), light rail, streetcar (also called trolley), commuter rail, and bus rapid transit. Forgotten in the research is the influence that express bus systems and their stations can also have on real estate values or rents. This research helps close the gap. We find surprisingly robust associations between XBT stations on office and apartment rents well beyond one mile, and strong associations with respect to retail rents although these are limited to locations closest to XBT stations. Transit and land use planning and policy implications are offered.

\subsection{INTRODUCTION AND LITERATURE REVIEW}

Cities emerge largely because agglomeration economies create economic development synergies: the larger and more densely developed, the more jobs are created (Ciccoine and Hall 1996; Bettencourt and West 2010). This can stress transportation systems as congestion may lead to inefficient economic interactions that reduce advantages of agglomeration (Glaeser 2011). In the US, one solution is to build new highway networks connecting downtowns to suburbs, suburbs to each other, and even metropolitan areas to one another (Duany, Plater-Zyberk and Speck 2000). Opening vast amounts of cheap land for development allowed people to move outward where housing was cheaper (per square foot) which in turn attracted firms to locate near its labor supply (Bruegmann 2006). But these highway networks also became congested, arguably undermining overall metropolitan economic performance (Duranton and Turner 2011; Litman 2017).

During the last quarter of the $20^{\text {th }}$ century, dozens of metropolitan areas built and expanded fixed route transit (FRT) systems, in part to overcome the diseconomies of congestion (Nelson 2017). Indeed, studies have shown that overall metropolitan economic performance improves with the presence of FRTs generally (American Public Transportation Association 2007; Weisbrod, Cutler, and Duncan 2014). Studies attributing economic development outcomes to specific modes of public transit have focused on rail services and bus rapid transit (BRT) (Belzer et al. 2011; Nelson et al. 2015; Nelson 2015). Other work by Higgins and Kanaroglou (2015) assesses the contribution of rail transit and BRT to property values, which is a proxy for economic development (see also Institute for Transportation and Development Policy 2013).

Yet, no study has explored the relationship between express bus transit (XBT) and economic outcomes. This article helps close this gap in the research. 
But just what is express bus transit (XBT)? For instance, while Levinson et al. (2003) offers these features of BRT systems, we contend they are features of XBT systems (Levinson et al., 2003: 36):

High-occupancy vehicle (HOV) busway

Freeway HOV lanes have express bus service and stations

Busway along abandoned railroad line

Express buses use contra-flow bus lanes on freeway

Peak-period freeway bus lane busway with stations along unused railroad

In contrast, BRT systems are characterized as having uniquely designed buses (in part to achieve brand identity); stops, stations, terminals and corridors that clearly define the BRT operating area; and the benefit of intersection signalization priority (see Nikitas and Karlsson (2015: 2).

While many XBT systems have features similar to BRT systems, there is an important difference. Express bus services do not operate principally on surface streets. They instead operate substantially (though not exclusively) in freeway/expressway high-occupancy-vehicle lanes, abandoned railroads and other abandoned transportation routes, or other means not associated with regular streets. Put differently, where bus rapid transit operates substantially on surface streets, though ideally within dedicated travel lanes and synchronized intersections, express bus service operates substantially on entirely separate conveyances.

These distinctions may be subtle but they are important because, without clarity, attempts to measure such things as economic development outcomes may be compromised. In this particular context, we are interested in knowing whether XBT systems per se may be associated with real estate rents and, by implication, values. This chapter explores this proposition. We begin with a theory, method and model of associating XBT systems with real estate rents followed by its application to nearly 30 XBT systems across the United States. We conclude with implications for transit and land use planning.

\subsection{RESEARCH APPROACH}

This section outlines our research approach including a review of relevant theory, research design, general model, functional form, study areas, and specific model and data.

\subsubsection{Theory}

Conventional urban location theory developed by Alonso (1964), Mills (1964), and Muth (1967) — also known as the AMM theory — shows that where all jobs are in the central business district (CBD), the cost of transportation increases with respect to distance from the CBD at a declining rate. Transportation costs reduce land value as distance from the CBD increases. Where transportation costs are lowest, in the CBD, land prices are highest. There is thus competition for location near CBDs considering the land use needs among competing office, retail, institutional, residential and other land uses. Only those land uses that generate the highest 
economic exchanges win the most central locations. Land uses that cannot compete for CBD locations are pushed outward to areas where they can outbid other land uses, a process called urban land use invasion and succession (Park, Burgess, McKenzie and Wirth. 1925).

As one relaxes constraints of the AMM monocentric city model, it is possible to imagine the same principles are at work only at smaller scales in a more distributed fashion (Hajrasouliha and Hamidi 2017). In particular, rail transit stations can become localized versions of CBDs. Accordingly, economic activities will bid up land prices close to rail transit stations; lower value activity moves away from stations to locations where they may outbid competing land uses. Dozens of studies show negative bid-rent gradients with respect to distance from rail transit stations suggesting these local level outcomes. Yet none address the proximity effects of XBT stations on commercial rents (See Higgins \& Kanaroglou 2016).

We apply theory to these small CBDs, called XBT station areas.

\subsubsection{Research Design}

We apply theory through a static, cross-section quasi-experimental research design. That is, using one period of time (early 2018), we test for the effect of XBT stations on real estate rents across multiple metropolitan areas with XBT systems. Though analysis is not causal, associations can be used as guidance for transit and land use planning purposes.

\subsubsection{General Model}

Using these theoretical and research design foundations as a guide, we develop the following general model to test the theory. It is adapted from Nelson (2017):

$$
R_{i}=f\left(S_{i}, S_{i}, P_{i}, U_{i}, L_{i}, D B_{i}, M_{i}\right)
$$

Where:

$\mathbf{R}$ is the asking rent per square foot for property $i$;

$\mathbf{S}$ is the set of structural attributes of property $i$ including its architecture, mass, height, age and effective age, interior amenities, flow efficiencies and so forth;

SES is the set of socioeconomic characteristics of the vicinity of property $i$ such as population features, income, education;

$\mathbf{P}$ is a set of planning, zoning and other development restrictions applicable to property $i$;

$\mathbf{U}$ is a set of measures of urban form of the vicinity of property $i$ such as the nature of surrounding land uses, terrain, physical amenities (such as parks), street characteristics and related;

$\mathbf{L}$ is a set of location attributes of property $i$ such as distance to downtown and other activity centers, and distance to nearest major highways including freeway/expressway ramps; 
DB is the distance from the closest point of a parcel to the centroid of the FRT station centroid; and

$\mathbf{M}$ is a set of metropolitan area controls. As metropolitan area conditions and markets vary between them, identifying the location of property $i$ within its respective market helps control for metropolitan-specific influences.

\subsubsection{Functional Form}

The AMM theory posits that land value will decline with distance from the CBD or other high activity nodes. Linear, semi-log, and double-log functional forms are the dominant forms reported in literature (Higgins and Kanaroglou 2016).

The linear functional form assumes a straight line deduction in property value with respect to distance away from a node, such as a transit station.

The semi-log functional form — where the dependent variable is logged — estimates the percent change in value associated with a unit change in an independent variable.

The double-log functional form generates elasticities—continuously measured variables on both sides of the equation are logged although categorical and binary variables are not.

In our view, none of these functional forms are highly useful to transit and land use planners who need to know how to arrange transit investments and land use policies to maximize the economic benefits of transit station proximity. Lacking guidance from studies using these conventional functional forms, planners tend to settle on quarter-mile and half-mile planning areas around stations, with very little empirical justification.

A less-used approach, the quadratic functional form, is specified such that the linear distance term is squared and both terms are included in analysis. It has the potential to pinpoint the break point in the transit station distance curve. In the context of FRT stations, the concern is that rail stations themselves can be nuisances such that real estate values and rents may be dampened very near them. As Nelson and McClesky (1990) theorize, the market capitalizes both positive amenity effects of rail station proximity as well as negative amenity effects, for instance those associated with noise (such as dispatching broadcasts at station platforms), and congestion (such as when vehicles use park and ride lots during peak hours) (Nelson 1992). So long as positive amenity effects outweigh negative ones, the bid-rent gradient will slope downward and away from rail transit stations. However, in theory it is possible for negative amenity effects to outweigh positive ones. But quadratic functional forms may not be very useful either, especially if both signs are in the same direction (increasing or decreasing value at a faster rate with respect to distance). Even where signs are different, the smaller the second term relative to the first the flatter the slope. For example, if the second term above is 1.00 , the minima is 10 miles which may not be very useful to planners crafting plans around stations.

Distance bands offer a practical middle ground between knowing whether and the extent to which real estate markets respond to transit stations within discrete distances of FRT stations. They also provide statistical significance test results for each band separately. Unfortunately, 
most distance-band studies use only one-quarter or one-half mile distance bands, (see Higgins and Kanaroglou 2016) or occasionally two bands (see Nelson 2017). But that assumes all relevant interactions which are useful for planners to know occur only within those distance bands, and that those bands apply to all transit modes in all metropolitan areas. Following Hibberd et al., (2018) and Nelson and Hibberd (2019) this article expands on and applies the distance band concept, described in more detail below. 


\subsubsection{Study Area}

Given that no literature reports the association between XBT station proximity and commercial rents for office, multifamily and retail activities, we do so here. In particular, we apply the general model with various functional forms to XBT stations in 33 metropolitan areas (see Table 10.1). We excluded metropolitan areas in the Great Lakes and Northeast regions of the U.S. along with Los Angeles and San Francisco because they are very large metropolitan areas with multiple fixed route transit systems that may make it difficult to tease out XBT associations from other FRT systems.

Table 10.1: Metropolitan Area Express Bus Transit Systems Analyzed

\begin{tabular}{l}
\hline Metropolitan Area \\
\hline Albuquerque \\
\hline Atlanta \\
\hline Austin \\
\hline Buffalo \\
\hline Charlotte \\
\hline Cincinnati \\
\hline Dallas-Fort Worth \\
\hline Denver \\
\hline Eugene \\
\hline Houston \\
\hline Kansas \\
\hline Little Rock \\
\hline Miami \\
\hline Minneapolis-St. Paul \\
\hline Nashville \\
\hline New Orleans \\
\hline Ogden \\
\hline Orlando \\
\hline Phoenix \\
\hline Pittsburgh \\
\hline Portland \\
\hline Reno \\
\hline Sacramento \\
\hline Salt Lake City \\
\hline San Antonio \\
\hline San Jose \\
\hline Seattle \\
\hline St. Louis \\
\hline Tacoma \\
\hline Tampa \\
\hline Tucson \\
\hline Virginia Beach \\
\hline Washington, DC \\
\hline
\end{tabular}




\subsubsection{Specific Model and Data}

We operationalize the general model dimensions and functional form here. Notably, we report the statistical association between rent per square foot for office, retail and multifamily properties with respect to XBT station proximity using one-eighth mile distance bands, holding other factors constant.

$\mathbf{R}$ is the asking rent per square foot for property $i$ reported by CoStar during 2017. Rents are annual for office and retail properties and monthly for multifamily properties. These include all properties with space for rent from among office, retail, and multifamily real estate projects. 22 By logging the dependent variable, the semi-log model allows for coefficients to be interpreted as the percent change in rent attributable to a one unit change in an independent variable such as an individual distance band.

$\mathbf{S}$ is the bundle of structure attributes for property $i$ reported by CoStar. This includes occupancy characteristics noted below. For all properties, this includes:

Gross leasable area in building square feet with the expectation that there will be a positive association between building area and rent because larger buildings presumably include more amenities than smaller ones.

Effective year built which is the later of the year of construction or the year of renovation as reported by CoStar with the expectation that newer buildings will command more rent than older ones.

Vacancy rate with the expectation that the higher the vacant rate the lower the rent. However, this may not always be the case as high demand markets could result in high vacancy rates as owners wait for higher paying tenants. Accordingly, signs may not be predictable especially considering that the study area is comprised of stable to rapidly growing central counties.

For office properties structural attributes also include binary variables indicating whether the building is considered Class A or Class B with the expectation that Class A rents will be higher than Class B which will in turn be higher than Class $C$ which is the referent building class.

The number of Stories is also included with the expectation that the taller the building the higher the mean rent. However, for retail, Stories are excluded because of scant variation among retail structures.

Retail structures are also coded by whether or not $(1,0)$ they are classified as Power Center, Neighborhood Center, Community Center, Regional Mall, Lifestyle Center and Outlet Mall. As there is no literature allowing us to predict signs of association between these activities and our referent, Strip Centers, we do not predict directions of association.

22 Normally, statistical analysis is applied to samples of a universe. In this case, the study includes the universe of all properties reported by CoStar. As CoStar data come from real estate brokerages participating in its network, the data exclude non-participating brokerages or entities and properties not for rent such as owner-occupied properties. 
For multifamily facilities, occupancy restrictions are included, notably Senior or Student housing with Market Rate housing being the referent. The expectation is that relative to Market Rate multifamily units, rents for Student housing will be lower but rents for Senior housing will be higher.

The SES vector is comprised of Median Household Income from the five-year sample of the 2016 American Community Survey (ACS) for the block group within which a CoStar property is located, for which a positive association is expected with respect to rent (see Xiao 2016).

The attributes for the $\mathbf{P}$ vector are missing because resources did not allow us to identify planning and zoning conditions applied to the nearly 20,000 properties in our data base.

Two variables comprise the $\mathbf{U}$ dimension. The first is our calculation of jobs-housing balance, being the number of jobs in a census block group (BG) from the Longitudinal EmploymentHousehold Dynamics database divided by the number of residents of labor force age (being 15 to 65 years old) which we call Workers per Labor Force. The higher the ratio the more people work in the BG relative to those who live there. As such, more pressure is put on rents so we expect a positive association (see Stoker and Ewing 2014).

The second variable, Entropy, is patterned after Ewing and Hamidi (2014) who use an entropy calculation as a proxy for land use mix. The greater the mix, the higher rents should be because of efficiencies gained in the interaction between land uses.

Two variables comprise the $\mathbf{L}$ dimension. The first location control is Distance from Downtown for which a negative association is expected based on the AMM theory. Using Google Earth, we identified the central most point of each downtown. The second location control is Distance from Freeway which is defined as the nearest freeway or expressway ramp. Because freeway ramps can be considered nuisances in addition to being an accessibility benefit, no signs of association are predicted.

DB is defined as the location of the subject property within one-eighth mile distance bands of the nearest FRT station outward to two miles. We use closest distance, calling it the "front door", assuming that, over time, structures will orient themselves to be close to transit stations. We also measure straight line distance; future research will measure network distance. The two-mile distance was used to assure a maximum reasonable distance to estimate distance band effects based on work by Nelson et al. (2015) for Dallas office rental market light rail transit effects (about 1.75 miles) and Petheram et al. (2013) for the Salt Lake County multifamily building light rail transit assessed value effects (about 1.25 miles). For instance, in the equations,

$$
>0.125-<=0.250 \text { mile }
$$

means property $i$ is in the distance band that is greater than 0.125 miles but less than or equal to 0.250 miles from the nearest street car transit station.

While a positive association is expected between DBs and XBT stations, negative associations can signal externality effects noted above. For instance, areas very near stations may have nuisances such as traffic, noise, and poor urban design that offset positive effects of proximity. But DBs farther away may have positive coefficients. Finally, the DB approach allows us to estimate how far away from transit stations the market values proximity, which is important for transit and land use 
planning. In the regression results reported below, significant DB coefficients, where $p<0.10$ of the two-tailed test since direction of association is theorized, are noted in bold red. Theory allows for both positive and negative signs, with negative signs indicating localized nuisances associated with FRT stations and nearby land uses become negative externalities internalized as lower rent.

Further, for presentation and illustration purposes, we allow for a $\mathbf{D B}$ skip between significant DB coefficients. For instance, if DB coefficients are significant through 0.325 mile, but not in the next DB for 0.500 mile, but the next one is significant, to 0.625 , we highlight the coefficients for the significant DBs but not any others. Again for presentation and illustration purposes, we do not highlight significant coefficients of DBs if there are two or more DBs with insignificant coefficients between them. Dallas is the exception to this protocol.

The $\mathbf{M}$ vector is comprised of the individual metropolitan counties within which the XBT systems operates. As these are controls which account for idiosyncrasies of metropolitan markets, no direction of associations is predicted.

Our models include many times more data than used in most prior studies (see Higgins and Kanaroglou for comparison). While we have no a priori expectations of goodness of fit outcomes, literature suggests that ordinary least squares hedonic (regression) analysis can explain about one fifth to three quarters of the variation in the observed rent for cases.

Some analysts may be preoccupied with achieving high levels of regression model explanation. Yet, too many variables can lead to over-specification. It is best to emphasize the variables most relevant to the question, with some related controls sufficient to avoid serious omitted variable bias (a form of endogeneity) in the model. Our model is based on both theory and a large body of prior empirical work.

Table 10.2 summarizes the variables, source of data, and directions of association. 
Table 10.2: Variables, Data Sources, and Predicted Association with Respect to Rent per Square Foot

\begin{tabular}{|c|c|c|}
\hline Structure Controls & Data Source & Predicted Sign \\
\hline Gross Leasable Area & CoStar & + \\
\hline Class A Office & CoStar & + \\
\hline Class B Office & CoStar & + \\
\hline Stories & CoStar & + \\
\hline Effective Year Built & CoStar & + \\
\hline Vacancy Rate & CoStar & - \\
\hline Power Center & CoStar & na \\
\hline Neighborhood & CoStar & na \\
\hline Community & CoStar & na \\
\hline Regional & CoStar & na \\
\hline Lifestyle & CoStar & na \\
\hline Outlet & CoStar & na \\
\hline \multicolumn{3}{|l|}{ Occupancy Control } \\
\hline Senior & CoStar & na \\
\hline Student & CoStar & na \\
\hline \multicolumn{3}{|l|}{ Socioeconomic Control } \\
\hline Median Household Income & Census ACS & + \\
\hline \multicolumn{3}{|l|}{ Land Use Mix Controls } \\
\hline Workers per Labor Force & LEHD, ACS & + \\
\hline Entropy & LEHD & + \\
\hline \multicolumn{3}{|l|}{ Location Controls } \\
\hline Distance Downtown Center & Computed & + \\
\hline Distance Freeway Ramp & Computed & $+/-$ \\
\hline \multicolumn{3}{|l|}{ Distance Band } \\
\hline $1 / 8$ mile bands to 2.0 miles & Computed &,$++/-$ \\
\hline
\end{tabular}

We present results next followed by implications for transit and land use planning. 


\subsection{RESULTS AND DISCUSSION}

Table 10.3 reports regression results for office, multifamily and retail properties respectively with respect to XBT transit station proximity. Figures 10.1 illustrate the link between XBT station proximity and significant coefficients where $\mathrm{p}<0.10$, using the two-tailed t-test because both directions of association are possible.

The coefficients of determination are modest, explaining from about 22.5 percent to 43.5 percent of the variation in rents. For the most part, control variables have the correct signs and reasonable magnitudes. Notably, the structure variables for which directions are predicted along with the socioeconomic control performed as expected. The land use mix variables performed mostly as expected although with some negative associations with respect to entropy. The location variables performed as expected with some negative associations with respect to freeway ramp distance, as anticipated.

With respect to XBT station distance bands, we find:

- Office rents decline gradually from the first distance band to the 1.625-mile distance band;

- Multifamily rents decline gradually from the first distance band to the 1.875-mile distance band and

- Retail rents begin with a positive premium at the first distance then fall steeply over the next two distance bands.

These empirical outcomes, based on tens of thousands of commercial properties in more than 30 metropolitan areas, are surprising with respect to the distance over which there seems to be a rent premium with respect to office and multifamily properties being more than 1.5 miles and nearly 2.0 miles respectively. These are comparable to the distances found in Chapter 2 for multifamily rents for SCT and CRT systems but in other respects being much longer.

A key finding is that it appears that offices and apartments value proximity to XBT stations much more so than BRT stations. In Chapter 2, we found no rent premiums for office, apartments or retail buildings in the first ( 0.125 mile) distance band with limited premiums only to about one mile away. We explore reasons next. 

Table 10.3: The Link between XBT Station Proximity and Office, Multifamily and Retail Rents per Square Foot

\begin{tabular}{|c|c|c|c|c|c|}
\hline \multicolumn{2}{|c|}{$\begin{array}{c}\begin{array}{c}\text { Office Rents with Respect to XBT } \\
\text { Station Proximity }\end{array} \\
\end{array}$} & \multicolumn{2}{|c|}{$\begin{array}{c}\text { Apartment Rents with Respect to XBT } \\
\text { Station Proximity }\end{array}$} & \multicolumn{2}{|c|}{$\begin{array}{c}\text { Retail Rents with Respect to XBT } \\
\text { Station Proximity }\end{array}$} \\
\hline Variables & Office & Variables & Multifamily & Variables & Retail \\
\hline Constant & 0.963 & Constant & -1.913 & Constant & -0.033 \\
\hline Structure Controls & & Structure Controls & & Structure Controls & \\
\hline Gross Leasable Area & $-1.388 E-007$ & Gross Leasable Area & $-2.277 \mathrm{E}-008$ & Gross Leasable Area & $-7.836 \mathrm{E}-007$ \\
\hline Class A Office & 0.321 & Average Unit Size & $-5.077 \mathrm{E}-005$ & Effective Year Built & 0.001 \\
\hline Class B Office & 0.088 & Stories & 0.025 & Vacancy Rate & 5.659E-005 \\
\hline Stories & 0.006 & Effective Year Built & 0.001 & Power Center & 0.204 \\
\hline Effective Year Built & 0.001 & Vacancy Rate & 0.003 & Neighborhood & -0.015 \\
\hline \multirow[t]{4}{*}{ Vacancy Rate } & -0.001 & Occupancy Control & & Community & 0.075 \\
\hline & na & Senior & 0.014 & Regional & 0.370 \\
\hline & na & Student & -0.165 & Lifestyle & 0.324 \\
\hline & na & & na & Outlet & 0.172 \\
\hline \multicolumn{2}{|l|}{ Socioeconomic Control } & \multicolumn{2}{|l|}{ Socioeconomic Control } & \multicolumn{2}{|l|}{ Socioeconomic Control } \\
\hline $\begin{array}{l}\text { Median Household } \\
\text { Income }\end{array}$ & $1.598 E-006$ & $\begin{array}{l}\text { Median Household } \\
\text { Income }\end{array}$ & 2.945E-006 & $\begin{array}{l}\text { Median Household } \\
\text { Income }\end{array}$ & $2.838 E-006$ \\
\hline \multicolumn{2}{|l|}{ Land Use Mix Controls } & \multicolumn{2}{|l|}{ Land Use Mix Controls } & \multicolumn{2}{|l|}{ Land Use Mix Controls } \\
\hline $\begin{array}{l}\text { Workers per Labor } \\
\text { Force }\end{array}$ & 0.000 & Workers per Labor Force & 0.003 & Workers per Labor Force & 0.002 \\
\hline Entropy & -0.042 & Entropy & 0.066 & Entropy & 0.034 \\
\hline Location Controls & & Location Controls & & Location Controls & \\
\hline $\begin{array}{l}\text { Distance Downtown } \\
\text { Center }\end{array}$ & $-5.712 E-007$ & $\begin{array}{l}\text { Distance Downtown } \\
\text { Center }\end{array}$ & $-3.961 E-007$ & $\begin{array}{l}\text { Distance Downtown } \\
\text { Center }\end{array}$ & $-4.666 \mathrm{E}-007$ \\
\hline Distance Freeway Ramp & 5.913E-007 & Distance Freeway Ramp & $-3.407 E-006$ & Distance Freeway Ramp & $-2.413 E-006$ \\
\hline
\end{tabular}


Table 10.3: The Link between XBT Station Proximity and Office, Multifamily and Retail Rents per Square Foot—continued

\begin{tabular}{|c|c|c|c|c|c|}
\hline \multicolumn{2}{|c|}{$\begin{array}{l}\text { Office Rents with Respect to XBT } \\
\text { Station Proximity }\end{array}$} & \multicolumn{2}{|c|}{$\begin{array}{l}\text { Apartment Rents with Respect to XBT } \\
\text { Station Proximity }\end{array}$} & \multicolumn{2}{|c|}{$\begin{array}{l}\text { Retail Rents with Respect to XBT } \\
\text { Station Proximity }\end{array}$} \\
\hline Variables & Office & Variables & Multifamily & Variables & Retail \\
\hline Distance Band & & Distance Band & & Distance Band & \\
\hline$<=0.125$ mile & 0.090 & $<=0.125$ mile & 0.075 & $<=0.125$ mile & 0.014 \\
\hline$>0.125-<=0.250$ mile & 0.107 & $>0.125-<=0.250$ mile & 0.092 & $>0.125-<=0.250$ mile & -0.015 \\
\hline$>0.250-<=0.375$ mile & 0.100 & $>0.250-<=0.375$ mile & 0.080 & $>0.250-<=0.375$ mile & -0.037 \\
\hline$>0.370-<=0.500$ mile & 0.095 & $>0.370-<=0.500$ mile & 0.082 & $>0.370-<=0.500$ mile & 0.007 \\
\hline$>0.500-<=0.625$ mile & 0.085 & $>0.500-<=0.625$ mile & 0.047 & $>0.500-<=0.625$ mile & $\begin{array}{l}-0.005 \\
\end{array}$ \\
\hline$>0.625-<=0.750$ mile & 0.078 & $>0.625-<=0.750$ mile & 0.065 & $>0.625-<=0.750$ mile & 0.006 \\
\hline$>0.750-<=0.875$ mile & 0.068 & $>0.750-<=0.875$ mile & 0.056 & $>0.750-<=0.875$ mile & 0.009 \\
\hline$>0.875-<=1.000$ mile & 0.041 & $>0.875-<=1.000$ mile & 0.048 & $>0.875-<=1.000$ mile & -0.039 \\
\hline$>1.000-<=1.125$ mile & 0.038 & $>1.000-<=1.125$ mile & 0.063 & $>1.000-<=1.125$ mile & -0.041 \\
\hline$>1.125-<=1.250$ mile & 0.049 & $>1.125-<=1.250$ mile & 0.040 & $>1.125-<=1.250$ mile & -0.014 \\
\hline$>1.250-<=1.375$ mile & 0.044 & $>1.250-<=1.375$ mile & 0.035 & $>1.250-<=1.375$ mile & -0.003 \\
\hline$>1.370-<=1.500$ mile & 0.061 & $>1.370-<=1.500$ mile & 0.030 & $>1.370-<=1.500$ mile & $\begin{array}{l}-0.024 \\
\end{array}$ \\
\hline$>1.500-<=1.625$ mile & 0.012 & $>1.500-<=1.625$ mile & 0.031 & $>1.500-<=1.625$ mile & -0.018 \\
\hline$>1.625-<=1.750$ mile & 0.073 & $>1.625-<=1.750$ mile & 0.020 & $>1.625-<=1.750$ mile & 0.004 \\
\hline$>1.750-<=1.875$ mile & 0.068 & $>1.750-<=1.875$ mile & 0.025 & $>1.750-<=1.875$ mile & 0.024 \\
\hline$>1.875-<=2.000$ mile & 0.088 & $>1.875-<=2.000$ mile & 0.013 & $>1.875-<=2.000$ mile & $\begin{array}{l}-0.028 \\
\end{array}$ \\
\hline
\end{tabular}


Table 10.3: The Link between XBT Station Proximity and Office, Multifamily and Retail Rents per Square Foot-continued

\begin{tabular}{|c|c|c|c|c|c|}
\hline \multicolumn{2}{|c|}{$\begin{array}{c}\text { Office Rents with Respect to XBT } \\
\text { Station Proximity } \\
\end{array}$} & \multicolumn{2}{|c|}{$\begin{array}{c}\text { Apartment Rents with Respect to XBT } \\
\text { Station Proximity } \\
\end{array}$} & \multicolumn{2}{|c|}{$\begin{array}{c}\text { Retail Rents with Respect to XBT } \\
\text { Station Proximity } \\
\end{array}$} \\
\hline Variables & Office & Variables & Multifamily & Variables & Retail \\
\hline Metropolitan Controls & & Metropolitan Controls & & Metropolitan Controls & \\
\hline Albuquerque & -0.333 & Albuquerque & -0.315 & Albuquerque & na \\
\hline Atlanta & -0.014 & Atlanta & -0.217 & Atlanta & -0.019 \\
\hline Austin & 0.036 & Austin & -0.036 & Austin & 0.248 \\
\hline Buffalo & -0.333 & Buffalo & -0.232 & Buffalo & -0.359 \\
\hline Charlotte & -0.073 & Charlotte & -0.327 & Charlotte & 0.073 \\
\hline Cincinnati & -0.416 & Cincinnati & -0.449 & Cincinnati & -0.317 \\
\hline Dallas-Fort Worth & -0.108 & Dallas-Fort Worth & -0.145 & Dallas-Fort Worth & -0.116 \\
\hline Denver & 0.101 & Denver & 0.097 & Denver & 0.140 \\
\hline Eugene & -0.031 & Eugene & -0.162 & Eugene & 0.009 \\
\hline Houston & -0.058 & Houston & -0.242 & Houston & -0.042 \\
\hline Kansas & -0.255 & Kansas & -0.430 & Kansas & -0.301 \\
\hline Little Rock & -0.247 & Little Rock & -0.537 & Little Rock & -0.329 \\
\hline Miami & 0.156 & Miami & 0.059 & Miami & 0.350 \\
\hline Minneapolis-St. Paul & -0.307 & Minneapolis-St. Paul & -0.151 & Minneapolis-St. Paul & -0.144 \\
\hline Nashville & 0.012 & Nashville & -0.178 & Nashville & 0.050 \\
\hline Ogden & -0.324 & Ogden & -0.385 & Ogden & -0.153 \\
\hline Orlando & -0.022 & Orlando & -0.159 & Orlando & 0.110 \\
\hline Phoenix & -0.090 & Phoenix & -0.231 & Phoenix & -0.132 \\
\hline Pittsburgh & -0.160 & Pittsburgh & -0.208 & Pittsburgh & -0.241 \\
\hline Portland & 0.033 & Portland & -0.015 & Portland & 0.090 \\
\hline Reno & -0.121 & Reno & -0.174 & Reno & -0.097 \\
\hline Sacramento & -0.004 & Sacramento & -0.066 & Sacramento & na \\
\hline
\end{tabular}


Table 10.3: The Link between XBT Station Proximity and Office, Multifamily and Retail Rents per Square Foot—continued

\begin{tabular}{|c|c|c|c|c|c|}
\hline \multicolumn{2}{|c|}{$\begin{array}{c}\text { Office Rents with Respect to XBT } \\
\text { Station Proximity }\end{array}$} & \multicolumn{2}{|c|}{$\begin{array}{c}\text { Apartment Rents with Respect to XBT } \\
\text { Station Proximity }\end{array}$} & \multicolumn{2}{|c|}{$\begin{array}{c}\text { Retail Rents with Respect to XBT } \\
\text { Station Proximity }\end{array}$} \\
\hline Variables & Office & Variables & Multifamily & Variables & Retail \\
\hline Salt Lake City & -0.181 & Salt Lake City & -0.261 & Salt Lake City & -0.087 \\
\hline San Antonio & 0.116 & San Antonio & -0.206 & San Antonio & -0.092 \\
\hline San Jose & 0.521 & San Jose & 0.391 & San Jose & 0.471 \\
\hline Seattle & 0.140 & Seattle & 0.151 & $\begin{array}{l}\text { Seattle } \\
\end{array}$ & 0.233 \\
\hline St. Louis & -0.217 & St. Louis & -0.379 & St. Louis & -0.233 \\
\hline Tacoma & -0.206 & Tacoma & -0.214 & Tacoma & -0.162 \\
\hline Tampa & -0.093 & Tampa & -0.172 & Tampa & -0.038 \\
\hline Tucson & -0.155 & Tucson & -0.345 & Tucson & -0.112 \\
\hline Virginia Beach & -0.252 & Virginia Beach & -0.241 & Virginia Beach & -0.152 \\
\hline Washington & 0.578 & Washington & 0.327 & Washington & 0.719 \\
\hline Model Performance & & Model Performance & & Model Performance & \\
\hline Cases & 28,084 & Cases & 43,355 & Cases & 37,811 \\
\hline R2, adjusted & 0.377 & R2, adjusted & 0.435 & R2, adjusted & 0.225 \\
\hline F-ratio & 288.593 & F-ratio & 556.617 & F-ratio & 184.017 \\
\hline \multicolumn{2}{|c|}{ Selected Descriptive Statistics } & \multicolumn{2}{|c|}{ Selected Descriptive Statistics } & \multicolumn{2}{|c|}{ Selected Descriptive Statistics } \\
\hline Rent Square Foot/Year & $\$ 21.94$ & Rent Square Foot/Month & $\$ 1.39$ & Rent Square Foot/Year & $\$ 19.87$ \\
\hline Gross Leasable Area & 51,686 & Gross Leasable Area & 116,498 & Gross Leasable Area & 18,422 \\
\hline $\begin{array}{l}\text { Median Household } \\
\text { Income }\end{array}$ & $\$ 64,720$ & $\begin{array}{l}\text { Median Household } \\
\text { Income }\end{array}$ & $\$ 49,854$ & $\begin{array}{l}\text { Median Household } \\
\text { Income }\end{array}$ & $\$ 56,946$ \\
\hline $\begin{array}{l}\text { Distance Downtown } \\
\text { Center }\end{array}$ & 53,396 & $\begin{array}{l}\text { Distance Downtown } \\
\text { Center }\end{array}$ & 47,989 & $\begin{array}{l}\text { Distance Downtown } \\
\text { Center }\end{array}$ & 52,309 \\
\hline Distance Freeway Ramp & 7,052 & Distance Freeway Ramp & 7,000 & Distance Freeway Ramp & 8,216 \\
\hline
\end{tabular}

\section{Comments:}

Significant $(p<0.10)$ non-metropolitan control variables in bold.

Significant $(\mathrm{p}<0.10)$ distance band variables in bold red.

Albuquerque and Sacramento have missing CoStar retail cases. 


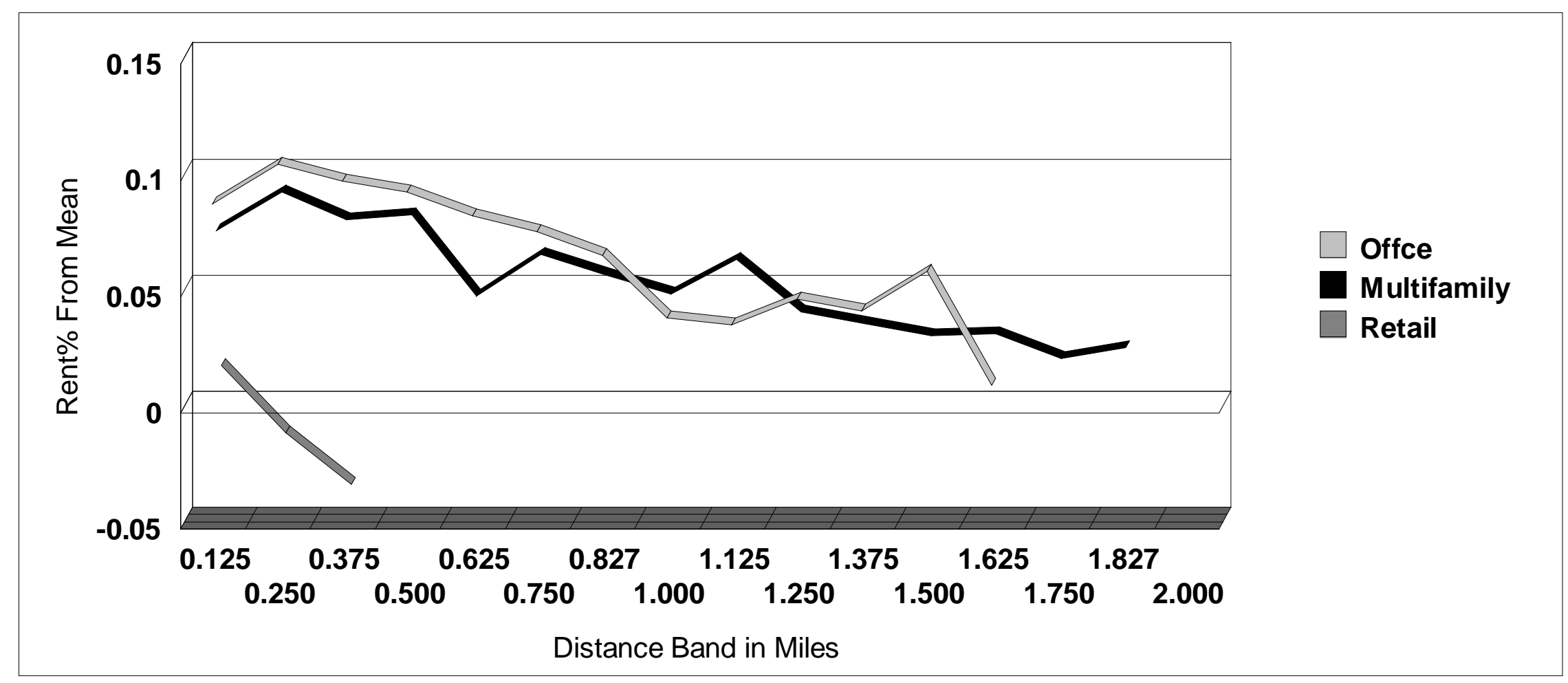

Figure 10.1: The percent rent change from the mean between XBT station proximity and office, multifamily and retail rents per square foot 


\subsection{IMPLICATIONS FOR TRANSIT AND LAND USE PLANNING}

This research indicates that the commercial real estate market values proximity to XBT stations with office and multifamily rent premiums extending more than 1.5 miles and near 2.0 miles, respectively. These are rent premium distances comparable to streetcars and CRT, considerably more than office with respect to LTRT, and considerably more than BRT for both real estate types. In a word, XBT results are perplexing.

Perplexing because conventional wisdom assumes that since they have fewer stops between nodes than LRT, BRT and SCT, they provide access to fewer opportunities, Moreover, XBT systems tend to operate only during peak commuting hours during weekdays. And though some may use high-occupancy vehicle lanes and in a few metropolitan areas enjoy signalization priorities, for the most part they operate in regular travel lanes. Finally, with few exceptions, XBT investments are modest and routes are easily changed to meet new demands, which can undermine market confidence in long term transit accessibility.

Except for retail, the rent premium distances suggest that workers and multifamily residents are willing to work or live 1.5-2.0 miles from XBT stops. They likely do not walk those distances however, but rather using park-and-ride/kiss-and-ride at residential stops, and feeder transit services such as conventional bus. We also know anecdotally that some XBT systems include $\mathrm{Wi}-\mathrm{Fi}$ and other amenities onboard which can allow for some productivity en route.

Clearly, more research is needed to explore how XBT systems can meet market needs, and facilitate economic development. 


\section{REFERENCES}

Alonso W (1964). Location and Land Use: Toward a General Theory of Land Rent, Harvard University Press, Cambridge MA.

American Public Transportation Association, Public Transportation: Benefits for the 21st Century Washington, DC: American Public Transportation Association, 2007.

Arrant, Tony. "Planning and Growth Management”, Chapter 11 in Florida Association of Governments. Florida County Government Guide. Florida Association of Governments, Tallahassee, FL: 111-127, 2012.

Baltes, Michael, Victoria Perk, Jennifer Perone, and Cheryl Thole. "South Miami-Dade Busway System Summary." National Bus Rapid Transit Institute, University of South Florida, 2003.

Belzer, Dena, Sujata Srivastava, Mason Austin, Tyler Bump, and Jeff Wood.Transit and Regional Economic Development. No. FTA CA-26-1007-03, 2011.

Bettencourt, Luis and Geoffrey West. “A Unified Theory of Urban Living.” Nature (October 2010): 467.

Bruegmann, Robert. Sprawl: A Brief History. University of Chicago Press, Chicago, 2006.

Carnegie Mellon Center for Economic Development. Methods of Regional Analysis: Shift-Share. H. John Heinz School of Public Policy and Management, Carnegie Mellon University, Pittsburgh, PA, undated. Accessed from http://www.andrew.cmu.edu/user/jp87/URED/readings/Shift_Share.pdf. (No date.)

Ciconne, Antonio and Robert E. Hall. "Productivity and the Density of Economic Activity." American Economic Review 86(1), (1996): 54-70.

Duany, Andres, Elizabeth Plater-Zyberk and Jeff Speck. Suburban Nation: The Rise of Sprawl and the Decline of the American Dream. North Point Press, New York, NY, 2000.

Duranton, Gilles, and Matthew A. Turner. "The Fundamental Law of Road Congestion: Evidence from US Cities.” American Economic Review 101(6), (2011): 216-52.

Ewing, Reid and Shima Hamidi (2018). The Costs of Sprawl. London: Routledge.

Glaeser, Edward, Triumph of the City: How Our Greatest Invention Makes Us Richer, Smarter, Greener, Healthier, and Happier. Penguin, New York, NY, 2011.

Guerra, Erick and Robert Cervero (2011). "Cost of a Ride: The Effects of Densities on FixedRoute Transit Ridership and Costs.” Journal of the American Planning Association 77 (3), (2011): 267-290.

Guthrie, Andrew and Yingling Fan. (2016) Economic Development Impacts of Bus Rapid Transit. Center for Transportation Studies University of Minnesota, Minneapolis, MN. 
Hajrasouliha, Amir H. and Shima Hamidi (2017). The typology of the American metropolis: monocentricity, polycentricity, or generalized dispersion? Urban Geography 38:3, 420-444, DOI: 10.1080/02723638.2016.1165386.

Hibberd, R., A. C. Nelson, K. Currans. Functional Form in Hedonic Regression: Literature Review \& Test of Forms to Determine the End of Significance of Transit Proximity Effects on LVU. University of Arizona.

Higgins, Christopher D. Higgins \& Pavlos S. Kanaroglou (2016). Forty years of modelling rapid transit's land value uplift in North America: moving beyond the tip of the iceberg, Transport Reviews, 36:5, 610-634, DOI: 10.1080/01441647.2016.1174748

Institute for Transportation \& Development Policy. Best Practices 2013. Accessed from https://www.itdp.org/library/standards-and-guides/the-bus-rapid-transit-standard/best-practices2013/

Levinson, Herbert, Samuel Zimmerman, Jennifer Clinger, Scott Rutherford, Rodney L. Smith, John Cracknell, and Richard Soberman. Bus Rapid Transit, Volume 1: Case Studies in Bus Rapid Transit. Transportation Research Board, Washington, DC, 2003.

Litman, Todd. Evaluating Public Transit Benefits and Costs. Victoria Transport Institute, Victoria, BC, 2017.

Mills ES (1967). An Aggregative Model of Resource Allocation in a Metropolitan Area, The American Economic Review, Papers and Proceedings, 57(2), pp 197-210. University of Chicago Press, Chicago.

Muth RF (1969). Cities and Housing: The Spatial Pattern of Urban Residential Land Use, Third Series: Studies in Business and Society.

Nelson Arthur C. (2017). Transit and Real Estate Rents. Transportation Research Record: Journal of the Transportation Research Board. https://doi.org/10.3141/2651-03:

Nelson, Arthur C. (1992). Effects of Heavy-Rail Transit Stations on House Prices with Respect to Neighborhood Income, Transportation Research Record, 1359: 127-132.

Nelson, Arthur C. and Susan J. McClesky (1990). Elevated Rapid Rail Station Impacts on Single-Family House Values, Transportation Research Record, 1266: 173-180.

Nelson, Arthur C. Dejan Eskic, Shima Hamidi, Susan J. Petheram, Jenny H. Liu, Reid Ewing. 2015. Office Rent Premiums with Respect to Distance from Light Rail Transit Stations in Dallas. Transportation Research Record DOI 10.3141/2500-13.

Nelson, Arthur C. and Robert Hibberd (2019). Streetcars and Real Estate Rents. Transportation Research Record (forthcoming).

Nelson, Arthur C. Foundations of Real Estate Development Financing: A Guide to PublicPrivate Partnerships. Island Press, Washington, DC, 2014. 
Nelson, Arthur C. National Study of BRT Development Outcomes. Portland, OR: National Institute for Transportation and Communities accessible from https://pdxscholar.library.pdx.edu/trec_reports/32/ (2015).

Nelson, Arthur C. Transit-Oriented Developments Make a Difference in Job Location. Fordham Urban Law Journal 44(4), (2017): 1079-1102.

Nelson, Arthur C., Bruce Appleyard, Shyam Kannan, Reid Ewing, Matt Miller, and Dejan Eskic. "Bus Rapid Transit and Economic Development: Case Study of the Eugene-Springfield BRT System." Journal of Public Transportation 16(3), (2013): 41-57.

Nelson, Arthur C., Matt Miller, Dejan Eskic, Keuntae Kim, Reid Ewing, Jenny H. Liu, Matt Berggren, Zakari Mumuni. Do TODs Make a Difference? Portland OR: National Institute for Transportation and Communities, Portland State University, OR, 2015.

Nikitas, Alexandros and MariAnne Karlsson. "A Worldwide State-of-the-Art Analysis for Bus Rapid Transit: Looking for the Success Formula." Journal of Public Transportation 18(1), (2015): 1-33.

Park, Robert Ezra, E. W. Burgess, Roderick Duncan McKenzie, and Louis Wirth. 1925. The city. Chicago, Ill: University of Chicago Press.

Petheram, Susan J., Arthur C. Nelson, Matt Miller and Reid Ewing (2013). Using the Real Estate Market to Establish Light Rail Station Catchment Areas: Case Study of Attached Residential Property Values in Salt Lake County with respect to Light Rail Station Distance. Transportation Research Record. 2357: 95-99.

Rodrigue, Jean-Paul and Theo Notteboom. Transportation and Economic Development. Retrieved November 5, 2017 from https://people.hofstra.edu/geotrans/eng/ch7en/conc7en/ch7c1en.html.

Stoker, Philip \& Reid Ewing (2014) Job-Worker Balance and Income Match in the United States, Housing Policy Debate, 24:2, 485-497, DOI: 10.1080/10511482.2013.852604

Weisbrod, Glen, Derek Cutler and Chandler Duncan. Economic Impact of Public Transportation Investment. American Public Transportation Association, Washington, DC, 2014.

Xiao, Yang (2016). Hedonic Housing Price Theory Review in Urban Morphology and Housing Market, pp. 11-40. New York: Springer. 



\subsection{THE LINK BETWEEN TRANSIT AND LAND USE PLANNING TO MEET AMERICA'S MARKET DEMAND FOR TRANSIT STATION PROXIMITY}

Our concluding chapter includes a research agenda and a perspective on the role of fixed route transit systems in meeting.

\section{Research Agenda to Further Understand the Role of Fixed Route Transit Systems in Shaping Development Patterns}

The current research, which builds on our prior research, creates the platform for what we call the FINAL PHASE of this research genre. It would need to include development and hedonic analyses, both of which we pioneered for their application to fixed guideway transit systems. The following agenda is envisioned

\section{Economic Base Analysis}

Our prior and ongoing research uses quasi-experimental, economic base methods to assess change in concentration in:

- Jobs by sector;

- Jobs by wage category;

- Population and households by age and other demographic features; and

- Residential units and tenure relative to central counties with respect to transit mode by time period before, during and after the Great Recession).

Using factor/cluster analysis, we would refine analysis to consider outcomes with respect to types of transit stations by mode. Factor/cluster analysis dimensions would include these among others as appropriate:

- $\quad$ Land use mix (an entropy measure);

- Jobs-population balance (a measure of jobs versus population concentration);

- Distance to downtown and other major activity centers (a centrality measure);

- Employment sector composition (a measure of economic concentration); and

- Socioeconomic composition (a measure of demographic concentration) 
Without predicting those types, we anticipate they include combinations of spatial (downtown, suburban center, isolated), economic (high-middle-low wage corresponding to relative education and skill levels), and social dimensions (age-income-race/ethnicity-tenure).

We anticipate that there may be surprises compared to our prior work, such as gains in concentration at types of transit stations that otherwise saw losses of concentration for systems as a whole, and vice versa. Refined analysis can lead to refined planning and urban design practices.

\section{Hedonic Analysis}

We pioneered the use of CoStar rent data to assess the association between transit station distance and rent with respect to different system types and metropolitan areas. Our FINAL PHASE would disaggregate systems into types of stations based on factor/cluster analysis outlined above. We would also be mindful of opportunities to apply more rigorous analyses including larger numbers of economic, demographic and spatial controls.

We anticipate advancing work in this field in another way: assessing the interactive effect of transit station type and distance on commercial properties within discrete distance bands of stations. In our current work, we have discovered that commercial markets express segmentation effects based on distance to transit stations, by mode. For instance, commercial property rents are much more responsive to BRT station proximity than to SCT proximity for reasons that are different between these systems. The FINAL PHASE research agenda would allow us to explore these refinements to market responses to transit systems by mode, type and distance.

We conclude with a review of why all this research is important.

\section{Perspectives about the Role of Fixed Route Transit Systems in Meeting America's Future Development Needs}

Two themes emerge from this research. First, the real estate market values proximity to various forms of transit, often extending up to two miles away. In other words, the real estate market confers a premium on rents for many kinds of commercial real estate beyond the standard halfmile circle that seems to dominate transit-oriented development (TOD) planning (see Petheram et al. 2013).

The second is that for the most part changes in jobs, people and households are confined to the very closest distance bands around transit stations. While it makes sense for development that values transit station proximity to occur nearby, there may be opportunities for transit-oriented development farther away that are unrealized. For instance, a substantial literature indicates that firms are attracted to transit stations up to a mile and often further away (Nelson 2017). It is not that workers are necessarily willing to walk longer distances but often feeder buses, shuttles, and even pleasant and barrier free walkways/bikeways facilitate accessibility.

Moreover, there is a growing literature based on market surveys indicating that people would choose to live a half mile away, or more, from transit stations if they had the opportunity (Nelson 2013). One indicator of this willingness is the presence of market premiums for light rail and streetcar proximity well beyond one mile (see Chapter 2). Yet, the largest share of the change 
people and households occurs within one-eighth (0.125) mile of LRT and SCT stations (see Chapter 5). For workers it is the first quarter (0.25) mile (see Chapter 3 ).

Why is this? It may be that local planning does not seize market opportunities for maximizing development throughout the half-mile circle or beyond. Among many barriers identified in the literature (see Canepa 2007; Chatman and E. DiPetrillo 2011; Guthrie and Fan 2017) combined with our own professional observations include:

- Development regulations that are inconsistent with market realities;

- Unpredictable or protracted development approval processes;

- Excessive parking requirements;

- Development exactions that exceed that needed to mitigate adverse impacts;

- Neighborhood opposition;

- Inefficient linkages between development and transit stations (such as multi-lane highways, long blocks, and elevated station platforms among others); and

- Insensitive urban design that makes transit station accessibility physically and even emotionally unpleasant.

But for these barriers, more jobs, people and households are likely to locate within a half mile, a mile or more from transit stations (Canepa 2007). For example, suppose development across the entire 0.50 -mile area around transit stations were similar to that observed for the first 0.125 -mile. For instance, in metropolitan Denver, the 0.125 -mile LRT station areas absorbed $8.7 \%$ of all household growth despite comprising only $0.4 \%$ of the urban land area. If extended over 0.50mile, 1.5 times more than all of the Denver metropolitan area's household growth 2010-2016 could have been absorbed. Not all households would choose to live near transit stations, of course. Still, using market surveys produced by the National Association of Realtors, Nelson (2013) estimates that even if all new housing built between 2010 and 2050 were within 0.50-mile of existing transit stations, market demand for housing proximate to transit stations would remain unmet.

There is another consideration. Our preliminary analysis of the land area within 0.50 mile of transit stations in many of the metropolitan areas investigated in our study indicate that more than half the area is comprised of

- Surface parking lots,

- Vacant, privately owned land, and 
- Land on which there are one- and two-floor structures being more than 30 years old and occupying less than $25 \%$ of the land area. 23

Real estate development literature indicates such land presents important opportunities for infill and redevelopment (Nelson 2014). One may imagine that much of the America's market demand for living and working near transit stations can be accommodated through the redevelopment of parking lots, vacant land, and aging buildings that are already beyond their highest and best use (see Nelson 2013 for elaboration).

Perhaps the greatest challenge for America's metropolitan areas is to meet the market demand for jobs and housing near rail transit stations by simply facilitating the redevelopment of its parking lots and aging, low-density structures.

23 These analyses are based on assessor records and Marshall and Swift depreciation schedules by building types. 


\section{REFERENCES}

Canepa, Brian, (2007). Bursting the Bubble: Determining Transit-Oriented Development's Walkable Limits. Transportation Research Record: Journal of the Transportation Research Board, 1992, pp 28-34.

Chatman, Daniel G. and Stephanie E. DiPetrillo (2011). Eliminating Barriers to TransitOriented Development. New Brunswick NJ: Alan M. Voorhees Transportation Center, Rutgers University.

Guthrie, Andrew and Yingling Fan (2017). Specific Strategies for Achieving Transit-Oriented Economic Development Applying National Lessons to the Twin Cities - Phase 2. Minneapolos MN: Center for Transportation Studies, University of Minnesota. Available at http://www.cts.umn.edu/Publications/ResearchReports/

Nelson, Arthur C. (2013). Reshaping Metropolitan America. Washington, DC: Island Press.

Nelson, Arthur C. (2014). Foundations of Real Estate Finance for Development. Washington, DC: Island Press.

Petheram, Susan J., Arthur C. Nelson, Matt Miller and Reid Ewing (2013). Using the Real Estate Markt to Establish Light Rail Station Catchment Areas: Case Study of Attached Residential Property Values in Salt Lake County with respect to Light Rail Station Distance. Transportation Research Record. 2357: 95-99. 